

\section{Donated to}

\section{LIBRARY}

UNIVERSITY OF CALIFORNIA

DAVIS

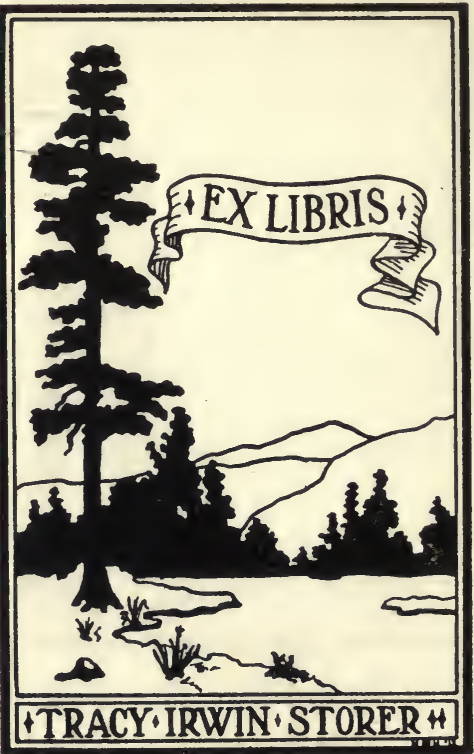



Digitized by the Internet Archive in 2007 with funding from Microsoft Corporation 



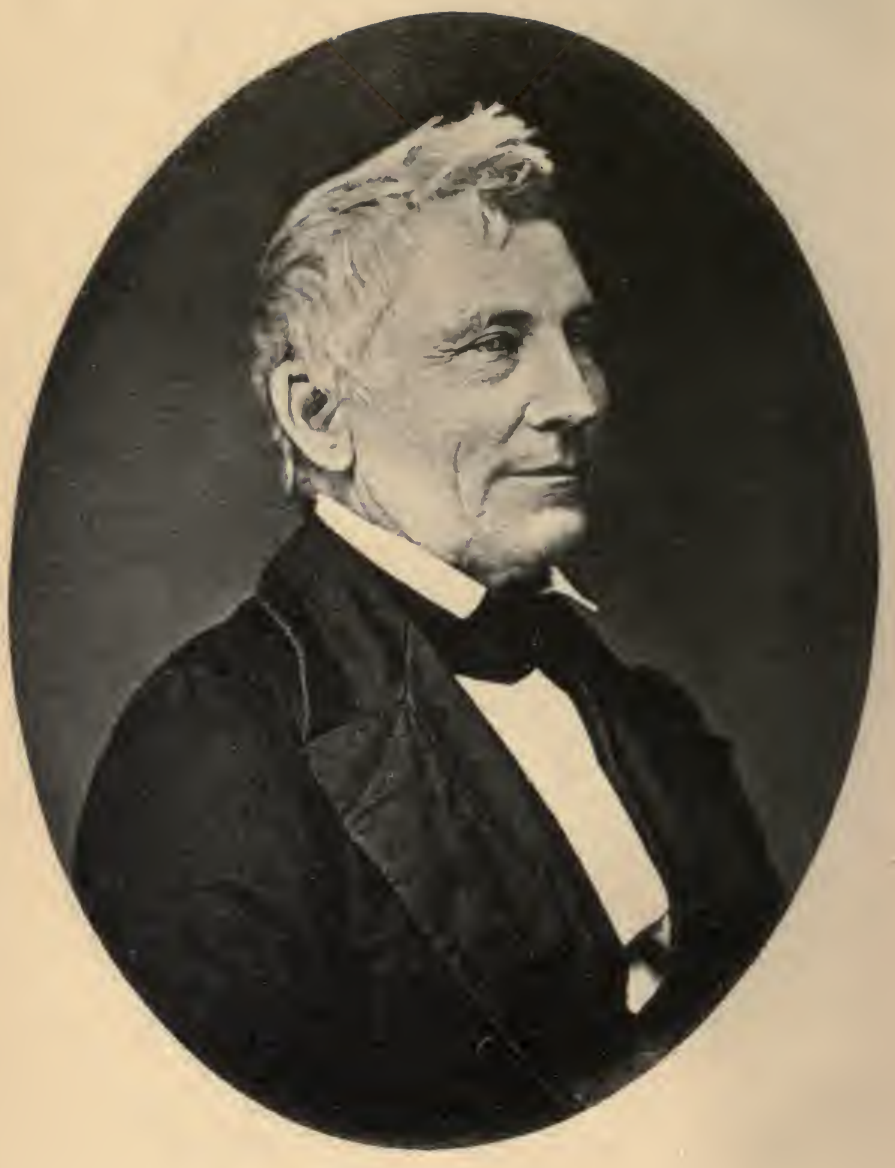

frapachman. 


\section{JOHN BACHMAN \\ D. D., LL. D., Ph. D.}

The Pastor of St. John's Lutheran Church, Charleston.

CHARLESTON, S. C. Walker, Evans \& Cogswell Co., 1888.

\section{LIBRARY UNIVERSIIY OF CALIFORNLA DAVIS}



TO THE MEMORY

OF

\section{REY. JOHN BACHMAN HASKELL,}

WHOSE UNWEARIED MINISTRY

AND

WATCHFUL LOVE

SUOTHED AND BRIGHTENED THE

CLOSING YEARS OF HIS GRANDFATHER'S LIFE, THIS VOLUME IS

AFFECTIONATELY INSCRIBED.

C. L. B. 



\section{CONTENTS.}

\section{CHAPTER I.}

\section{Youth and Training.}

Ancestry-Birth-Childhood-Early taste for Natural History-School and College Life-Training for the Ministry-Pastor Braun-Licensed to Preach to Three Churches in his Native County, Rennselaer, N. Y.-Ordination and Change of Field................

\section{CHAPTER II. \\ Pastor of St. John's.}

Called to St. John's Church, Charleston, S. C.-Early Ministry-Laying of the Corner-Stone of the New St. John's-Marriage-John Nicholas MartinBirth of Daughter-Second visit to his Northern Home.

\section{CHAPTER III.}

'The New S'T. John's.

Dedication of the New St. John's-Sunday-School Established-Summoned to the North by the Illness of his Father-Family Joys and Sorrows-The Death of his Father Induces another visit to his

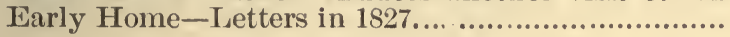

\section{CHAPTER IV.}

\section{ILLNESS.}

1827-Extreme Illness from a Fever contracted on the

"Great Lakes"-Extracts from his Journal-Letter to his Vestry-John G. Schwartz takes Charge of

St. John's in the Absence of the Pastor. 
Contents.

\section{CHAPTER V. \\ 1827-1833.}

Convalesence and return to Charleston-A Homestead Built-Death of his Twin Daughters-Nullification - His aged Mother-Letters..............................

\section{CHAPTER VI.}

1823-1835.

The Synod and Theological Seminary-Early History of the Lutheran Congregations at Ebenezer and Savannah-Visited by the Pastor of St. John'sFormation of the South Carolina Synod-Theological Seminary at Tennessee-Seminary in South Carolina-Rev. John G. Schwartz-Ernest Hazelius, D. D.-The Charleston Church prospersLetter from S. S. Schmucker, D. D.-Degree of Doctor of Divinity Conferred on the Pastor of St. John's

\section{CHAPTER VII.}

1831-1832.

Correspondence with Audubon-Natural History-A visit from the Naturalist Audubon-His Letters to Audubon .............................................................

\section{CHAPTER VIII.}

1833.

Address on Horticulture-Essay on the Migration of Birds.

\section{CHAPTER IX.}

\section{Labors in Natural History.}

1832 to 1835 -Letters to Audubon and his Sons-Successful Labors in Botany and Natural HistoryAnecdote of Oemler the Enthusiastic BotanistThe Visit of Audubon and his Family - Mr. Edward Harris, of Morristown, N. J.-A Night with the Hunters at Liberty Hall 
Contents.

\section{CHAPTER X. \\ Bachman and Audubon.}

1837-Union Between the Families of Bachman and Audubon-The Home-Letters to Audubon, and to his Sin, John W. Audubon-Visit to Baltimore - Letter to Mr. Edward Harris - Failing Health..........................................................

\section{CHAPTER XI.}

\section{VISIT TO EUROPE.}

Arduous Duties-Broken Health-Letter to Vestry Asking Leave of Absence-Farewell Sermon-Reception at London by Audubon-Diagnosis of Case by Eminent London Physicians-Journey to Scotland in Company with Audubon-Journal of European Travel-Switzerland-Lake ConstanceGermany-Society of Naturalists at FreyburgBerlin-Humboldt-Paris-Return of Unfavorable Symptoms-London - Visit to Earl of DerbyElected Foreign Correspondent of Zoölogical Society, London - Letter from John E. Gray Family Letters-Return-Double Union Between the Families of Bachman and Audubon.................

\section{CHAP'TER XII.}

Passing Under the Rod.

Family Letters-Mrs. Jacob Martin - Death of his Daughters-The Secret of Large Sympathy

\section{CHAPTER XIII. \\ Lights AND SHADOWS.}

Degree of Doctor of Philosophy Conferred-Elected to Various Scientific and Literary Societies in Europe and America-St. John's Church Colonizes-Letters to Audubon on his Return from Rocky Mountains-Quadrupeds of North America-Visit to Audubon-His Daughter Julia-Joy at the Birth of his First Grandson-Family Letters. 
Contents.

\section{CHAPTER XIV.}

Affliction.

Death of Mrs. Bachman-Letters to the Family-Letters to Audubon............................................... 227

\section{CHAPTER XV.}

Father and Daughter.

\section{- CHAPTER XVI. \\ Professor and Students.}

Depression of Spirits-Revival of Hope-Narrow Escape from Loss of Eyesight-Letters to Victor Audubon while Publishing Quadrupeds of North America-Agassiz-Attends a Meeting of General Synod, Convened at New York-Visits AudubonLetter from Hon. Mitchell King-Elected to Chair of Natural History in Charleston College-Anecdotes....

\section{CHAP'TER XVII.}

\section{His Second Marriage.}

Health Fails-Sojourn at Madison Springs-Visit from Victor Audubon-Letter to Edward Harris-Quadrupeds of North America-His Part in the Work......282

\section{CHAPTER XVIII. \\ LAETTERS AND JouRneys.}

1852-Letter on Education of Daughters-Visit to Eufaula-A Letter of Invitation to the North-The Invitation Accepted-Tour of the Great LakesJared P. Kirtland, M. D................................ 294 


\section{Contents.}

\section{CHAPTER XIX. \\ L I T E R A R Y W O R K .}

Open-air Preparation for Literary Work-Dictation to Amanuensis-Personal Recollections of Dr. Summers, and of Dr. John G. Morris-Literary ClubAdventures of a Club-night-Unity of the Human Race..............................................................

\section{CHAPTER XX.}

Scientific Labors.

An Examination of the Characteristics of Genera and Species-An Examination of Prof. Agassiz' "Natural Provinces"-Humboldt's Letter DestroyedLetter from Henry B. Schooleraft, Indian Commissioner...

\section{CHAPTER XXI.}

Defence of Luther.

Personal Recollectiors, by Dr. Summers-Defence of Luther and the Reformation-Lines on a FlyLeaf, by John L. Girardeau, D. D.-Natural History for Children-Hobbies-Snuff.............................

\section{CHAPTER XXII.}

\section{A Visit to Florida.}

Scientific and Pastoral Work-In the Home-The Mirabilis-His Amanuensis-Anxious Hours-A Successful Hunt-Visit to Florida.

\section{CHAPTER XXIII. \\ WORK FOR THE CHURCH.}

At Sixty-eight Vigorous and Hopeful-Even Tenor of Life Broken by Death of a Beloved Daughter-Sermon on Forty-third Anniversary of Ministry in Charleston-As Preacher and Pastor-Progressive Spirit-Southern Book of Worship-A Common Service-Lutheranism Sturdy and Uncompromising-Newberry College-Drs. Stork and Brown...... 


\section{Contents.}

\section{CHAPTER XXIV.}

\section{The Beginning of the War.}

Colored Congregation - His Defence--Old Plenty Boston Drayton-Bishop Payne-Jehu Jones-Sermon on Duty of the Christian to his CountryThe Ordinance of Secession-Letter to Edmund Ruffin-Takes on Hospital Stores to Virginia-A Comforter to his Grandson-Measles-Unexpected Visitors-Bread Cast on the Waters-Found Insensible-St. John's Church Closed..........................

\section{CHAPTER XXY. \\ DURING THE WA R.}

Christmas, 1863-The Children's Festival-Death of his Wife-Visit to Concord-Letters-Charleston Evacuated-He leaves for Columbia-Encounters the Federal Army at Cash's Station-Cruel Treatment-Return to Charleston-St. John's Re-opened-The Congregation Poor but United-Feebleness and Failing Eyesight.......................................

\section{CHAPTER XXVI.}

A F TER THE WAR.

An Assistant Pastor Engaged-Address on Humboldt - Fifty-fifth Anniversary Sermon- Rev. W. W. Hicks Elected Co-Pastor-Proposed Enlargement of St. John's-Opposition-The Scheme Abandoned-Resignation of Co-Pastor Accepted-Rev. John H. Honour Elected Associate Pastor-Fruit After Many Days-A Grandson Studies for the Ministry....

\section{CHAPTER XXVII.}

\section{Illiness and Convalesence.}

Letter from J. A. Brown, D. D., and Dr. Bachman's Reply-From Rev. J. B. Haskell-Reply to Letters from Milestown, Pa. - Correspondence Between John Haskell and his Grandfather-Letters to A. R. Rude, I. D.-Mr. John S. Fake-Rev. T. W. Dosh-Bereavement-Decline. 


\section{Contents.}

\section{CHAPTER XXVIII. \\ The Close of LIFE.}

From John Haskell's Diary - From Dr. WightmanDr. A. R. Rude-J. F. Ficken, Esq.-Memorial Services-Lines by Prof. W. J. Rivers-Bachman Endowment Fund-Mural Tablet in St. John's Church ..................................................... 434 



\section{TO THE READER.}

The materials for the Biography of JoHN Bachman, D. D., were collected with great labor and pains by his grandson, the late Rev. John Bachman Haskell, the appointed biographer, who wrote." I I think that the Biography, well done, would be worth my poor life." The accomplishment of this labor of love was frustrated by the protracted illness that preceded his death.

In compliance with his injunctions, the attempt has been made to weave the materials collected according to his plan-" Let him speak for himself, whenever it is possible."

A biography written by a near relative has its merits and its disadvantages. On the one hand, the pen of a stranger could not 
as readily indicate the springs of action, or give the finer touches to character: on the other hand, unconsciously, love may sometimes look with too partial an eye. The reader must be the judge ; we could only alopt the principle laid down- "Let him speak for himself."

The letters to Audubon take a prominent place, from the fact that they have been preserved, while others of equal, or of greater interest, at least to the Church, have been lestroyed.

Although the name of BACHMAx is closely interworen with the early life of the Lutheran Church in the South, yet the details of his labors here would weary the general reader, and would, necessarily, have been very imperfect.

Many of the letters written, while passing under the rod, seem too sacred for the critical eye of the public. But without these we could neither give the reader a glimpse into the tender, loving heart of the man and the father, nor could he trace the growth of that marrellous sympathy which enabled .JOHN BACHMAN to enter into the joys and sorrows of his fellow-men, almost as if they were his own. 
Valued tributes from the pulpit and the press, and memorial offerings from many friends, in prose and verse, we have been compelled to omit on account of the narrow limits of this commemorative volume.

C. L. Bachman.

Charleston, 1888. 



\section{CHAPTER I.}

\section{Youth and Training.}

ANCESTRY - BIRTH-CIILDHOON-EARLY TASTE FOR NATURAL HISTORY-SCHOOL AND COLLEGE LIFE-TRAINING FOR THE MINISTRY-PASTOR BRAUN-LICENSED TO PREACH TO THREE CONGREgATIONS IN HIS NATIVE COUNTY, RENNSElaAR, N. Y.ORDINATION AND CIANGE OF FIELD.

TOHN BACHMAN has left us in his own handwriting a few records, and very few, of his ancestry. He laid no undue stress on descent; yet would often say to his family, "I rejoice that I have come from an excellent stock ; for good, pure blood shows itself in men, as well as in animals, and thus far I prize it."

In 1858, he wrote a sketch of his life for a scientific journal in Europe. In it he says :

"My paternal ancestor, was a native of the Canton of Berne, Switzerland. After visiting England, he came to America as private Secretary to William Penn. Finally he settled near Easton, Penn, As a reward for faithful services rendered to the infant Colony, the Government granted him two Townships of land called, 'Upper and Lower Sackeny,' which are now settled by his numerous descendants. He was the seventh generation from the above. My ancestors on my mother's side, were from the kingdom of Würtemberg, Germany." 
His branch of the family removed to Dutchess Co., N. Y.

His father, Jacob Bachman, lived in the little town of Rheinbeck, near Schagticoke He was a successful farmer, who provided well for the comfort of his family. His mother, Eva, possessed sterling qualities; both parents were godly, active members of the Lutheran Church, in the Gilead Pastorate, N. Y.

The family consisted of one daughter, Eva, and three sons, Jacob, Henry and John. 'The youngest son, John, is the subject of this memoir.

Rev. J. N. Barnett, writing of the pastorate of Gilead, says: "A century ago their devotion challenges our admiration. Who now could be prevailed upon to wade through deep snow for miles to attend Divine service in mid-winter, where no heating device was countenanced?" "One old gentleman," (still living), "remembers to have heard his mother tell of carrying her children through cold and snow, a distance of three miles, to that unwarmed Church, to sit through services lasting almost the entire day." "These things are recorded in honor of the earnest and faithful men and women, from whom the worshippers of to-day are descended; who, in defiance of wintry storms and summer heats forsook not the assembling of themselves together about the altar of their God and Saviour." This is the good stock: that John Bachman prized, and this the hardy training of his early life. 
Among these sturdy, church-loving people he was born, February 4th, 1790, in the town of Rheinbeck, Dutchess County, State of New York. In due time, with much rejoicing, the baby of the family was taken to the old Stone Church and received the Sacrament of Baptism.

We recall many sweet pictures that he has left us of his childhood's home. $\Lambda$ s a boy he loved to sit beside his father and ask him about his forefathers.

The name of his first American ancestor, the secretary of William Penn, he has not recorded. Yet, it was surely an inspiration to the bright lad, to remember that his ancestor was no drone, no ignorant rustic, content simply to labor as a bread-winner. $\mathrm{He}$ was conscious that this legendary fore-father possessed a liberal education for his day. It pleased him to know that he was a brave and fearless worker, amidst the wilds and dangers of an infant colony. He rejoiced to feel that the Peace-maker, William Penn, had made no unwise selection when he chose a Bachman for his secretary-as the grant of townships by the Government gave conclusive evidence.

He delighted to hear, too, of the sturdy, loyal stock who remained in Switzerland-the Bachmans of Berne. We fancy that we can see the boy eagerly questioning his father about Lieutenant-General Bachman, of the Swiss Guard, who lost his life in defence of the unfortunate Louis XVI, of France, when John was two years of age. 'The boy's pulse must surely have quickened when he remembered 
that the same blood which flowed in the veins of the martyred hero, flowed in his. Thirty-eight years later he stood upon the soil of his forefathers. The grandeur and loveliness of the lake and mountain scenery held him spell-bound. At the western extremity of Lake Lucerne stands the city of the same name; and here he looked upon the monument designed by Thorwaldsen, in memory of those eight hundred Swiss who bravely sought, but failed, to defend the King, in the palace of the Tuileries, Paris, 1792. Few works of art, it is said, so profoundly impress the beholder.

The famous "Lion of Lucerne" is twenty-eight feet in length. It is chiselled out of the living rock on the side of a precipice. The gigantic, mighty king of the forest is dying; his paw rests protectingly upon the Bourbon shield, while the broken, fatal spear, still pierces his side. Above the sculpture is the motto,

"Helvetiorum Fidei ac Virtuti," (To the fidelity and valor of the Swiss.)

At the base is the roll of honor-on one side are the names of Commanders, twenty-eight in number, "Commanders who fell most bravely fighting." The name of Lieutenant-General Bachman is the second on the list; and the chronicler of that bloody defence, records that "Lieutenant-General Bachman was the soul of the expedition."

John's father fought in the Revolutionary W'ar. John was nine years of age when the news reached 
the little town of Rheinbeck, that Washington lay ill unto death. How eagerly must the boy have listened to his father, as he described his beloved Chief, as he had last seen him: "A grand man, over six feet in height, seated gracefully and firmly in his saddle, with a gentleness and graciousness of manner, that bespoke the Statesman, rather than the Warrior; and an attention to personal appearance that suited the festive hall, rather than the wilds of Virginia." Then his mother spoke of "Lady Washington," how she had presided over the "Federal Court" with stately courtesy and high toned breeding.

Perhaps, most of all, he liked to hear his father tell of Washington's exploits as a hunter; how keen, wary and successful he had been in field-sports, even in boyhood.

At that time there were but thirteen States in the Union. The telegraph and other modern inventions for transmitting news, were yet unknown; tidings came very slowly from the sick chamber at Mount Vernon, where the beloved chief lay on his death bed. At length a courier with dispatches rode up in haste; the great General and the first President of the United States, was dead. This sad event, that cast a gloom over the whole country, occurred December 14th, 1799.

In a few hours it was known in every farm-house in the little town of Rheimbeck that Washington was dead. Every detail of his last illness was quickly gathered up, and even the children paused 
to listen. John remembered the grief and excitement, and the preparations for what, in the simple village talk, was called " Washington's mock funeral." In every city and town, processions were formed that marched with badges of mourning through the principal streets to the churches, where suitable services were held and eulogies pronounced. In old age John Bachman would tell his grandchildren, "When a boy in Rheinbeck, I followed the procession at "Washington's mock funeral."

Those were days of stirring deeds in other lands. The old gazettes were anxiously expected; when they arrived, the sturdy farmer, in the evenings, laid aside his pipe and read to the assembled family the last foreign news - the announcement that the English General, Nelson, had destroyed the French fleet in Aboukir Bay. At another time, that the French General, with ten thousand men, after storming Jaffa, was retreating to Egypt, leaving a burning track behind him. Among the listening group, John was the eager questioner. Later the news came, "Napoleon has taken possession of the Tuileries and is declared first Consul," and, finally, "that he had been crowned Emperor of France." Perhaps the boy wondered why God had permitted the slaughter of the brave Swiss Guard while defending poor King Louis, whom the mob so soon put to death, and yet allowed Napoleon to be crowned Emperor of France. At least, it is not unlikely that his ambitious soul was fired by these stories of great men and great deeds. 
A stronger influence, however, was at hand. W'hen he was eleven years old, Rev. Anthon T. Braun became pastor of the church at Schagticoke.

The noble example, intellectual attainments, and earnest spirit of Pastor Braun, left their impress on the susceptible spirit of his young parishioner. Parental training had already broken for him the fallow ground, and prepared the mind of the boy for the reception of the good seed. The family discipline of our fathers would, in our day, be considered severe; yet the reverence of the child for the parent and pastor, did not interfere with mutual love; and childhood was not less happy or buoyant than to day.

The subject of this memoir tells us, "From my earliest childhood I had an irrepressible desire for the study of Natural History." Alluding to this period, his grandson, the Rev. John B. Haskell, has drawn the following picture:

"In our mind's eye, we see the little fellow, after the day's work has been done, running off, with rapid stride and beaming face, to wander over the hillsides, where, perchance, he might meet his friends, the squirrels, the chipmunk, or the many feathered fellow-citizens of the wood.

"Then we see him lying beneath some shady tree upon the bank of a stream watching, with his roving blue eyes, the steady flow of the waters Is he dreaming? Is he poetizing? Nay ; for suddenly we see the bright eye brighten in the intensity of its gaze, and following the eager look, we see slowly 
rising from the still surface, near the opposite bank, a round, dark head, with soft, lustrous brown eyes, glancing timidly around; then another little head appears, and losing all fear in the certainty of safety, the beavers boldly gambol and play up and down, to and fro, upon the stream ; till, their recreation over, they settle down to their business in a sober way. This change of action, discovers to the looker on, the little John Bachman, an unfinished beaver-dam, encroaching into the quiet brook. So our young naturalist studies the habits of the beaver. Suddenly the stillness of the evening is broken by the distant sound of a bell. Every beaver stops his work, and raises his head. We see a disappointed look steal into the watching eyes that peep through the willows on the bank; the young enthusiast would rather lose his supper, than the opportunity of delightful observation. Again, and louder sounds the clear bell; it is the prayerbell; the boy leaps to his feet; the little masons disappear with loud flappings of their trowel-like tails; and presto, the scene has changed to the farm-house, where the early evening meal has already ended. It is the thanksgiving hour, and the household kneels to seek, as the last united act of the day, Divine protection.

"The loving mother has saved the boy's supper and gives it to him, but not without the well merited rebuke for absence from the evening meal. Then the father turns to his paper and his pipe; the mother gives permission, and John is off like an 
arrow to the little rocky glen where the Pewee has his nest.

"Such are the faint pictures of his childhood, like some old ambrotype, or ancient photograph, with little, but the faded outlines, left; yet sweet to us with memories, and bright to us with beauty."

The schools of that day gave no long summer holidays, and on Saturdays, only an occasional half holiday; but when books were laid aside, he was free to follow the bent of his inclination, and, to his heart's content, explore the valley and hill-side.

Slavery still existed at that time in the State of New York, and like all his well-to-do neighbors, Jacob Bachman owned slaves. John, merry and daring, was idolized by these servants; especially by George, whose delight it was to accompany his young master into the woods, and to assist him to entrap animals and birds.

The boy's investigating spirit impelled him, under many difficulties, to make further research. He writes: "Such were the prejudices existing in the community in those early, unenlightened days, against the supposed trifling pursuits of Natural History, that I pursued my investigations by stealth, and labored without those guides which numerous scientific works now present."

One day, in Troy, perhaps, he met with several volumes at the book-sellers, that he ardently desired to possess. A happy thought came into the mind of the young, aspiring naturalist: "I will earn the money and buy the books. George will help me to 
catch the beaver and other fur-bearing animals, and I can sell the skins." The plan succeeded; in course of time the books were bought. He loved to tell his grandehildren how he sold his furs and purchased the coveted volumes.

His mother was proud of her little student. In his reminiscences he tells us, "My mother made room for my treasures, and on very cold, rainy evenings I had a fire in the 'spare room,' where I could study in quiet."

Very early in life he asked his father to send him to college. He had procured a Latin grammar, and was studying alone. No doubt Pastor Braun was then called upon to direct his Greek and Latin studies; and for recreation he had his few precious books on the Natural Sciences.

He was strong in body, buoyant of spirit, and hopeful in temperament. Very ready was he to take part in all out-door games that required swiftness of foot, or accuracy of eye.

One day a great honor was conferred upon the youth. The United States Exploring Expedition decided to make a visit to the Oneida Indians. Mr. Knickerbocker required a secretary, and John Bachman was selected to accompany him in that capacity.- It was, doubtless, a proud moment for the youth, and certainly must have recalled to his mind his old ancestor, who came from England to America as secretary to William Penn. With the blessing of father and mother he started with the party. 
In those days, of course, quill pens being used, the young Secretary was required to procure these for himself-and, as crow quills wore abundant, immediately he begun to make a large collection of the same.

He writes: "Because I collected crow quills, the Indians, in derision, gave me the soubriquet of 'Crow Quill ;'" soon after, however, we went on a Moose hunt. I took good aim, fired away, and heard them hallo: "Oh, you've killed him-you've killed him." So the Indians changed my name to "Big Moose." This took place in the western part of the State of New York; the skin and the horns of the Moose were taken home by the party and preserved in New York as a trophy."

When the time arrived for John to enter college, Williams College, Massachusetts, was selected. He was just a little shy, but was found well prepared to enter the Freshman Class. Some of the Boston boys called the boys from Rheinbeck, in contempt, "Dutchmen." John bore it for a time; on one occasion, however, when the parties met at the head of the steps, and "Get out of the way, you Dutchmen," was the taunt, John, boiling over with wrath, sprang forward, seized one of his tormentors by the arm, and sent him rolling down the steps. From the impetus he took a little tumble himself, but the class cheered, and the Rheinbeck boys henceforth were unmolested.

As the years rolled by, he became more and more absorbed in his studies; he sat up night ofter night 
studying and thinking. He who had been a hardy lad, breathing the pure country air, became a bookworm. No more merry snow-balling, no more outdoor, invigorating exercise. Suddenly, one day, he feels a sharp and racking pain-the brain has been over-fed, and the body denied its needful rest. The result was not strange, but to the ardent student startling and unlooked for-he had a hemorrhage of the lungs, and was forced, just as he was about to gain the goal of his ambition, to leave college without graduating.* It was a bitter and humiliating trial to him. He returned home weak and despondent. When strong enough, he roamed through the woody glens, and, resting under the shade of a tree, carved his name on the bark. But the healthful mother - Nature - was doing her appointed work. Sunlight and pure air, were her tonics; and, by degrees, hope revived, and strength of mind and body were renewed. Ambitious thoughts and aspirations again possessed his soul-but what avenue of distinction was now open to him? After much reflection, he selected the law as a profession; procured the books, and became interested in the study-still there was ever an unrest, an unsatisfied craving, within him.

His parents, from infancy, had instructed him in the Word of God-"Thy Word is a lamp unto my feet, and a light unto my path." One Sunday he took down an old volume from his father's book-

*The degree of Master of Arts was afterwards conferred upon him by Williams College. 
shelf, entitled "Luther on Galatians;" he read and re-read; the book sent him to his Bible, with prayer; new, higher, and holier aspirations, arose in his youthful soul-Jesus Christ, through St. Paul and Luther, had sent him a special message. He had often read, "Thou art no more a servant, but a son, an heir of God through faith;" but, to-day, the inspired words move his soul as they had never done before.

The next morning he opened his law-book, but could not fix his mind upon the subject; throwing it aside, he took his Bible and Luther on Galatians, and went into the woods. As he read and communed with his own heart, he saw no vision and heard no voice, save the still, small voice of his God. $\mathrm{He}$ said, "Speak, Lord; here am I," and the message came to his soul, "Go thou and preach to others the glad tidings that have set you free." Say to every prisoner of hope, "The just shall live by faith."

God had a definite work for him, and the glory of his life, henceforth, was to do the will of Him that sent him.

His mother was the first to mark his thoughtful brow, and before long, his parents and Pastor Braun were made acquainted with his hopes and aspirations. All approved heartily, and rejoiced at his decision. He was confirmed, and became Pastor Braun's student. The early part of his student-life was spent under the roof of this faithful friend and pastor. But, after a time, John 
craved advantages that his village liome could not offer him.

"I had intended." he writes, "to defray my own expenses by teaching, while studying for the ministry. First I went to Frankfort, Penn., where I remained nearly a year. On a short visit to Philadelphia, I met again the ornithologist, Wilson, and his nephew, William Duncan. Wilson had taught near Germantown, at Elwood School, Milestown, and Duncan was his successor; the position then vacant, was offered to me. Both Wilson and Duncan urged me to accept it. I taught at Elwood for a year. The school flourished in numbers: but was conducted in a very primitive fashion; the pupils were of both sexes and of all ages. A small class in Latin, one in French, and one in German, were, with difficulty, kept up during my short stay." But Philadelphia was the goal of his wishes. Probably his friend, Rev. Philip Mayer, contributed to bring about this change. He taught in Philadelphia a year, when his studies were so far completed, that he was licensed to preach.

It was probably during his early student-life that this reminiscence belongs. The singing was execrable in the old Church of which he was a member. Although 110 musician himself, he always loved good singing. He set to work, therefore; to remedy the evil, with all the zeal that ever characterized his attempts at reform. He procured a singing master, and, by his youthful eloquence, mustered a fine class. Soon the congregation took delight in the improved 
singing. He watched over his class with great pride, not at all disconcerted by the fact, that it was soon discovered that his voice added nothing to the fine music, (although in speaking it was flexible and melodious.) His class did not prove an exception to most church choirs-the members fell out. Sadly he looked on, determined to help, if possible, but biding his time. On the next Sunday he anxiously awaited the issue. The Pastor gave out the hymn; an ominous silence reigned in the little Church; John waited one moment, then, quick as thought, he rose in his seat and began to raise the tune. Smiles illumined the faces of the singers, and the leaders sang out lustily-and that was the end of the choir trouble. He would say to his grandchildren, with a twinkle in his eye, "My class was afraid of my bad singing, so I won the day." This little scene illustrates the generous tact that was a characteristic of the subject of this memoir. He knew how to incite those around him to action; he would set the example, and when his companions excelled him, he could step aside with a smile, and rejoice with them over the laurels they had won. Perhaps this selflessness was one great secret of his power over men.

Pastor Braun at this period, lived in his parsonage at Schagticoke, in that beautiful Hoosac region of country-a farm of fifty acres was attached to the house.

Rev. Barnett in his "Gilead Church History," writes, "For a part of his student-life, John Bach- 
man lived under the roof of this faithful minister." Pastor Braun is said to have been a man of fine abilities; an indefatigable worker, firm in his convictions, consistent in his principles, mild in his manner, forbearing toward the erring: and kind-hearted to a fault. He secured universal respect toward himself as a Christian gentleman and a faithful shepherd." In 18i2, this good man's health failed and he became a confirmed invalid; in 1813, at the age of sixty, he died. John Bachman became his successor, the sixth Pastor of the three Churches which formed the Gilead Pastorate. "For the training of such a man," says Rev. Barrett, "The Lutheran Church owes Pastor Braun a debt of gratitude. So prominent a place did he subsequently attain among the great and learned men of his time, on both sides of the Atlantic, and so identified was he with the progress of the Lutheran Church in this country, for more than half a century, as a man of extraordinary scientific attainments: that to merely mention Dr. Bachman's name here, will recall to mind more than can be written of him in this brief history, (Gilead,) and beget a feeling of just pride, to have it known that this illustrious man and eminent Christian, was born here, studied here, entered the ministry of the Church here, preached his first sermons here, and was one of the pastors of Gilead."

"Dr. Bachman remained in charge about a year and a half, when he was persuaded that duty and his health demanded his acceptance of a call to Charleston. This decision occasioned great sorrow. 
When he delivered his farewell sermon in Gilead, the voice of lamentation and weeping filled the house. At the close of the services they joined with him in singing a hymn the writer (Rev. Barnett) remembers to have heard in childhood, but which is no longer familiar. The first line was:

"I'll take my staff" and travel on."

The subject of this memoir has left in his memoranda this grateful record: "I was especially indebted to Dr. Quitman, of Rheinbeck; to Rev. A. Brown, of New York; and to Dr. Mayer, of Philadelphia, for their instructions while I was a student in Theology."

Rev. Dr. Quitman and Rev. Dr. Philip Mayer, of Philadelphia, are thus described: "They were remarkable men, of polished learning, courtly manners and noble bearing. Quitman had been a teacher in the family of the Prince of Waldeck. They kept the traditions of a State Church and aristocratic society. They were good pastors. They. have left behind them a social influence, still fragrant and wholesome. Their spiritual children are remarkable for their lofty integrity.*

These Christian gentlemen, doubtless, contributed towards the moulding of John Bachman's character; and the gracious manner which distinguished him through life, may, in part, be attributed to those early influences and associations.

*Rev. Edward T. Horn, in Year Book of the City of Charleston, 1884. 


\section{('HAP'TER II.}

\section{PAstor of ST. John's.}

Called to ST. JoHx's CHURCH, CHARLESTON, S. C.-EARIY MiNISTRY-LAYING OF THE CORNER-STONE OF TIE NEW ST. JOHN'S-MARRIAGF - JOHN NICHOLAS MARTIN-BIRTH OF DAIGHTER-SECOND VISIT TO HIS NORTHERN HONE.

THE subject of this memoir writes:

"I would gladly have spent the remainder of my days among the friends and relatives of $\mathrm{my}$ boyhood and early youth. A hemorrhage of the lungs, however, with which I had been attacked whilst at college, was making a fearful inroad on my health, and I was advised by my physicians to seek relief in a more Southern climate. I took a sea voyage to the West Indies, and recuperated greatly. On my return to Rheinbeck I found that a call had been sent from the congregation in Charleston, S. C., to the President of the Synod of New York, Dr. Quitman, with a request that he should recommend some clergyman who might be adapted to this field of labor. He was the father of General Quitman, and was regarded as one of the most learned and eloquent men of his day. He, and my ever faithful friend, Dr. Mayer, of Philadelphia, proposed my name to the Charleston congregation. They immediately sent me a call to become their pastor. After consulting with my family and congregation, they reluctantly gave me leave of absence. for nine months.

"An extra meeting of the Synod of New York had 
been convened for the purpose of ordaining me. It was held in the church where I had been baptized in infancy. Without returning home, I proceeded on my way to Charleston, S. C., and, on the 10th of January, arrived in the city. "The means of traveling were very different from what they are now in the days of steamers and railroads. The roads were almost impassable; as an evidence of this I would state that, with the exception of a Sunday, on which I preached for Dr. Mayer, of Philadelphia, I came in the regular stage line, which travelled day and night, and arrived at Charleston on the evening of the twenty-ninth day after leaving Dutchess County, which is a hundred miles north of the city of New York. In the meanwhile, our vehicles were either broken or overturned eight times on the journey.

"We were in the midst of a three years' war with the most powerful of foreign nations. Fearful battles had occurred on our Northern frontiers, on the ocean, and on the lakes. The traces of devastation and death were visible in the half-covered graves along the highway between Baltimore and Washington. The blackened walls of the Capitol at Washington, and the destruction in every part of the city, presented an awful picture of the horrors of war."

On his arrival in Charleston he was welcomed by a deputation from St. John's Lutheran Church. The President of the congregation, Col. Jacob Sass, took him to his own house. His good wife and himself made him perfectly comfortable, and treated him as an honored guest. No member of St. John's exceeded Col Sass in energy and faithfulness. His pastor described him thus: "He was one of the 
purest and best men it had ever been my privilege to be associated with." The young pastor's pale face disturbed and distressed his parishioner; "You must live much in the open air and ride on horseback," he said. The next day a good pony was put at his disposal. $\mathrm{He}$ rode out, and this was the scene that presented itself :

"I found our citizens working on the lines of defence thrown around the land-side of our cityeven ladies went there with hoes and spades to cheer the citizen-soldiers by their presence, their countenance, and example; and I, too, joined, at least in form, for it was our common country that was to be defended. In the meantime, the battle of New Orleans had been fought on the Sth of January, and a treaty of peace had been signed at Ghent; but these important events were not known until some time afterwards. The war had fallen heavily on our Southern people. The principle staple of our commerce, cotton, had for several years, during the embargo and war, been sold at a mere nominal value, and was stored away in various depositories in King street. Men had the necessaries of life, and these were sheap; but all the means of enterprise, and all the avenues to wealth, were closed up. Fortunately men were driven to the necessity of manufacturing their necessary articles, and they were compelled to deny themselves luxuries; they studied economy, and hence there was not much suffering among our people from any want of the necessaries of life. But the constant dread of invasion and the sufferings and dangers to which our friends, who were in the army and at sea, were constantly exposed, kept the minds of our citizens in an unsettled and feverish state. 
"When I arrived in Charleston, the congregation of St. John's worshipped in a small, wooden church, situated in the rear of the present church. It was an antiquated building of peculiar construction, resembling some of the old churches in the rural districts of Germany."

Before us lies, in water colors, the south view of the old Church, built A. D. 1756, and also a view of the interior. It looks roomy. The small pulpit is high, the beams naked, the chancel unrailed, and the white altar large. The Pastor was required to wear the gown.

One of the members of St. John's, Mrs. H. S. G., then a child, thus describes her impressions of the young pastor, on the Sunday he took charge of the congregation. "His height was medium; his figure slender; his complexion fair; features regular and eyes blue. He looked very young-though in his twenty-fifth year. His voice was strong, clear, and sweet. When the services were ended, we stopped to be introduced to him, and his bright smile immediately won our hearts."

It has been said of him, "Nature had made him tender-hearted and given him a tireless will." The congregation flourished greatly, and at Easter, sixty-four persons were confirmed. The building of a more commodious edifice was a pressing necessity ; subscriptions were forthwith collected, and contracts made for the same.

In the midst of his enthusiastic labors, he turned a deaf ear to the voice from Schaghticoke urging 2 
him, during the heated term, to seek a more bracing climate.

'The following letter from a young friend, $\mathrm{Mr}$. Charles A. D., gives us a glimpse into the childhood's home of the pastor of St. John's.

Troy, June 1st, 1815.

My Dear John: I was on a ride to Cambridge a few days ago. When I reached the forks of the road (say at Wallbridge's), I could not for the life of me resist the temptation to turn to the left; I jogged on slowly, keeping a bright look out for another left-handed turn. I soon discovered it, and had not proceeded far before I saw upon a tree "John Bachman" incised into the bark; convinced that I was, at any rate, where you once had been, I rode on. In a few minutes I had dismounted at your door. A young man met me at the gate, whom I recognized immediately as your brother. Your father was not at home; he had gone to Lansingburg. I remembered that I had passed an old gentleman on the road, and had noticed a likeness in him to the.picture of your father hanging in your room (in Charlestoni). I wish that I had stopped and spoken to him.

Your mother received me. As soon as I had said "I am Mr. Davis, from Charleston, a friend and neighbor of your son," I was made to feel almost as much at home as if I had been the Rev. Mr. Bachman himself.

Your good mother could not keep back a tear, when she spoke of your separation from them, and, I confess, I felt moved. They had many questions to ask, and I many stories to tell. They pressed me heartily to remain ; but I was compelled to go on ; promised, however, another visit soon. I rode 
off; but ere the spot was hidden from view that had witnessed so many pleasing occurrences of your youthful days, I could not but glance behind me at the quiet scene, and, as I ascended the hill, repeat to myself the old lines beginning

"Now love in this lone little spot with a maid, How blest he could live and how calm he could die."

$$
\text { C. A. D. }
$$

Before the close of the summer "Strangers' Fever," as it was called, made its appearance in Charleston. The cause of this Southern scourge naturally claimed his earnest attention. Dr. David Ramsay, the historian, wrote in 1800 ; "The disputes about the origin of Yelīow Fever, which have agitated the Northern States, have never existed in Charleston. There is but one opinion among the physicians and inhabitants, viz; that the disease is neither imported nor contagious." As this was, almost the unanimous opinion of the Medical Society, the rigid enforcement of the quarantine laws was not insisted upon. But the Pastor of St. John's did not regard the question as finally settled. He had taken part at the North in the vexed question, and now, under the tutorage of a member of his congregation, Dr. Benjamin Strobel, he studied more closely the history, nature, and treatment of the disease. He noted the course of treatment pursued by this successful practitioner, and before long, circumstances put his knowledge to the test. He tells us:

"The first summer after my settlement in Charleston, the yellow fever made its appearance there, and 
threatened soon to become epidemic. Some of my friends in the Church came to me and earnestly advised that, as I was not yet acclimated, it would be best for me to leave the city, make a visit to my friends in the North, and not return until the danger was over. I told them that I had no thought nor desire to do anything of the kind; that I had come to them to be their minister, and hardly thought it would be right for me to leave them in a time of trial, when they would probably have most need for my services. They continued to remonstrate with me for several days; but I stood to my resolution. Finally the Vestry sent me an official notice that the church would be. closed after the following Sunday, for the space of three months; and requested me to make that announcement from the pulpit. When Sunday came I made the announcement in accordance with the order of the Vestry; but followed it with the notice to the effect that we had secured the use of a vacant chapel for the next three months, where I would be pleased to meet with any of the congregation who might be disposed to come, at the usual hours for Sunday service.

"Soon after that I received a letter from home, telling me that my father was very ill, that he could not long survive, and that he was anxious to see me. Then I felt no hesitation about going. I took passage upon a ressel just about to sail for New York. Before we were at sea twenty-four hours, we had two men down with yellow fever, and the captain and all on board were very much alarmed at it, wondering what was to be done. I told the captain that if he would put the medicine chest at my disposal and keep all the crew and pissengers on deck, I would go below and take charge of the sick. He was greatly relieved at this, and made the necessary ar- 
rangements very promptly. Well, what with rough weather and head winds, we had a slow time of it and were out about two weeks. By the fourth day out I had, (I think, eight) patients on my hands. Of course, in the two weeks I did not take off my clothes, or go regularly to bed at all, and was on deck only once, to bury one of my poor fellows who had died. When we got to the quarantine station at New York my patients were all doing finely, though they were still as yellow as pumpkins."

As he was never very sea-sick, he soon recovered from the self imposed fatigue of nursing the sick.

Hastening, with anxious forebodings, to his old home, he found to his great joy, that his father was convalescent.

There was ltttle to mar the pleasure of this first visit to the scenes of his early labors. The next Sunday he was to preach to his former flock. His father said to him "John, let Marriage be the subject of your discourse." The hint was taken and the sermon prepared. On Sunday, long before the hour for service, the village congregations from the three churches flocked to the appointed place of worship. His text was a great surprise to many of his audience, for, until that morning, a profound secret had been faithfully kept.

When the services were ended, fifteen couples presented themselves to be united in marriage. John Bachman describes the scene thus:

"Intense excitement was betrayed by the congregation as the young people, in pairs, walked up the aisle. I stood at the altar and gave the exordium. 
Then I walked down the aisle asking the necessary questions of every couple, joined their hands together and pronounced them 'man and wife.' I was informed that as soon as it was known positively that I was expected in Rhinebeck, these young people determined to give me this pleasant surprise. Some had delayed their weddings, and others hastened their preparations."

An old letter of this date has been preserved by a member of the Horlbeck family. It is addressed to Mr. John Horlbeck, Senr., Charleston, S. C. 'The post-mark is Lansingburg, September 1st; it came duly to hand one month later, October 3rd; postage, $37 \frac{1}{2}$ cents.

Schaghticoke, Aug. 31st, 1815.

"I have enjoyed good health since I left you, and exposed myself so much to the heat of the sun, in riding and walking through the country, that I am several shades darker than I was when we parted.

"My dear father is much better than I expected to find him. He is remarkably cheerful, and did I not know that his disorder is a lingering and dangerous one, I would flatter myself that he might yet be perfectly restored to health. My uncle met me in Philadelphia, spent a week with us here, and then returned to his residence in Rheinbeck. He is one of Dr. Quitman's congregation. To-morrow I leave Albany for Rhinebeck, where I expect to meet the Synod. My old congregations are so anxious for me to continue with them, that they have sent petitions to the Synod, in hopes that its members may prevail upon me to accept their call. But I can assure you that though my native spot is dear to me, yet nothing would induce me to remain. 
Charleston I consider as my home; and unless its inhabitants treat me with greater neglect than they have heretofore done, they will have to keep me for life. I am anxious to hear what progress you make in building the new church. I hope you are all united and walk hand in hand. I am pleased to hear that yourself and brother are to do the brick work.

Give my best respects to Mr. Strohecker and family. He presented me with a cane to take with me as a present to my father. I thought highly of it, and carried it safe to Rhinebeck. There, in the hurry in putting my things on board of the boat, it was thrown into the dock. The boat could not wait, and I offered a dollar to the person who would dive for it. I hope to obtain it again, as a gentleman who resides there promised to attend to it. My father speaks often of the present; particularly on account of the distance it has been sent, the person who sent it, and the circumstance of its being of Orange wood.

Write me when it will be prudent for me to return to your city, as I shall not stay longer than is absolutely necessary. Yours, with esteem,

J. B.

The prudence exercised was in deference to the wishes of his Vestry.

Such was the zeal of the congregation of St. John's that, notwithstanding the absence of their pastor, the corner stone was laid on the $\delta$ th of August, Bishop Dehon, of the Episcopal Church, performing the ceremony.*

*On the death of Bishop Dehon, June, 1817, a letter of condolence was sent by the Vestry, and St. John's was draped in mourning. 
In the Fall of this year, with renewed strength and energy, he returned to his post of duty in Charleston.

Col. Sass again claimed the young pastor as his guest, and his grandson, Jacob Schirmer (then a lad), was at hand to offer his services to his pastor. In his old age, Mr. Schirmer used to tell us, with much glee, "And he did make use of me. I was the bearer of his love letters, when he was engaged in marriage to Miss Harriet Martin." In 1816 this happy union was consummated.

Miss Martin was the granddaughter of Rev. John Nicholas Martin, the fourth pastor of St. John's Lutheran Church, Charleston.

When the quaint little wooden church was dedicated, Jume 27th, 1764, on St. John Baptist's Day, under the name of St. John's Church, Pastor Martin was the minister in charge. He filled the pulpit acceptably for three years. In 1767 , he resigned his charge.

The Patriarch Missionary of the Lutheran Church, H. M. Muhlenberg, in August, 1773, heard Rev. Martin preach an afternoon sermon in St. John's, (Rev. Daser was then pastor), Muhlenberg's droll criticism of the sermon is preserved in his "Journal."

"Rev. Martin preached from the text, "My house shall be called a house of prayer.' He showed how we ought to go to the house of God, and how to behave outside of it. In the first part, he proposed six steps to lead us into it; the second part was intended for the other subject. All was ingeniously 
illustrated with sentences and quotations. But, from the shortness of time, and the great heat, (August 29th), he did not show us any other outlet, and we were obliged to return by those six steps, and finish where we had begun."*

We may hope that the heat, etc., had its full share in the short comings of that particular sermon, delivered by our brave, useful, and beloved ancestor.

In 1774 , a letter was sent to Pastor Martin, beseeching him to serve his old charge. He replied, "In compliance with the desire of the vestry, (St. John's), I will serve the Evangelical congregation of Charleston, one and a half years, etc. Deo volente, will take charge the first Sunday in Advent." When the time of this engagement drew to a close and there was no hope of obtaining a pastor from abroad, Pastor Martin was induced to engage for two years longer. The subject of our Memoir tells us, "During the storiny season of the Revolution the Germans of Charleston had been the strenuous advocates and defenders of the rights of their adopted country. 'The German Fusilier Company' was formed from the original members of St. John's congregation. They participated in the dangers and sufferings of the Revolution, and their captain fell at the siege of Savannah. Their pastor, the Rev. John Nicholas Martin, on his refusal to pray for the king, was driven from his church and

*Life and Times of H. M Muhlenberg, by W. J. Mann, D. D. 
his property confiscated. He was, for a time, under arrest, and afterwards was compelled to leave the city, to which he did not return until the close of the war."

His farm was situated about a mile from Charleston. The family chronicle tells us that during the Revolutionary War our own troops, "fearing that the farm-house might furnish a cover to the enemy's approach, twice put a torch to it." When Rev. Martin retired from the active ministry, he returned to his little farm-a spot connected with so many historical associations. Here, beloved and honored, he died at an advanced age, in 1797.

At this farm-house,* January 23rd, 1816, his granddaughter, Harriet, was united in marriage with Rev. John Bachman.

One of the old members of St. John's, (now deceased), remembered the first parsonage-a liouse in the western part of the city. Both husband and wife had a taste for gardening. Together they trained the vines, and soon the barren spot was made bright with annuals and roses.

In December a daughter, Maria, was born in the pastor's home.

August, 1817, we find him with his household, on a visit to the old homestead at the North. The farm-house was roomy and the welcome warm.

A faithful old colored nurse, Mary Ann, took charge of the baby. Mary Ann had felt sundry misgivings with regard to visiting "outlandish

*Now known as the Geiger Farm. 
places;" yet the abounding good cheer of the farm proved very acceptable to the old nurse. On their homeward journey, however, they spent a week in the City of New York. Nothing could exceed the discontent and disgust expressed by old Mary Ann. Everything she pronounced was better in Charleston. Vainly they tried to impress her by taking her to see the imposing buildings in the great city-all to no purpose; she insisted that an old, unsightly building in the suburbs of Cliarleston, the "Tobacco Inspection," was finer than any of them. So much for prejudice! 


\section{CHAP'TER III.}

The New St. John's.

Dedichtion OF THE NEW ST. JOHN'S-SUNDAY-SCHOOL ESTABLISHED-SUMMONED TO THE NORTI BY THE ILLNESS OF HIS FATHER-FAMILY JOYS AND SORROWS-THE DEATI OF HIS FATHER INDUCES ANOTHER VIJTT TO HIS EARLY HOMELeTtERS IN 1827.

THE corner-stone of the new St. John's had been laid August 8th, 1815. The mechanics were nearly all drawn from the congregation, and the work was vigorously carried on.

The old church was every Sunday crowded to overflowing. We can picture the congregation, after service, pausing to mark the progress of the new building. 'l'he members, young and old, did their part. The pulpit, with its high sounding-board, was the gift of the ladies of the congregation-(at the cost of $\$ 1,000$, exclusive of the mahogany, which was presented by Col. Sass). A year after the dedication of the church the tablets were put up by the young people. Thus all felt a lively and wholesome interest in the new church-building. Sunday, January 8 th, 1818, it was dedicated.

At 11.30 A. M., the vestry, headed by the venerable Col. Sass, the building committee, and the clergymen of the city: walked in procession from the old to the new St. John's. 
A band of music performed a sacred piece. (The organ was not completed until a year later.)

The impressive dedication service was read; Bishop Dehon and other Episcopal clergy assisting in the opening service.

The following hymn was sung, led by the Union Harmonic Society, accompanied by the band :

"And will the great eternal God On earth establish $\mathrm{His}$ abode? And will $\mathrm{He}$ from his radiant throne Regard our temples as His own."

The sermon was preached by the pastor; text, 1st Kings, viii c., 27th v.: "Behold, the heaven of heavens cannot contain Thee, much less the house that I have builded."

In 1819, we find him busy among the children of the church, organizing his Sunday-school.

Ever interested in the cause of education, the "German Friendly Society" school especially claimed his attention. For many years the institution flourished. Among the pupils in whom he took a deep interest, was his ward, John Schwartz, who uniformly held the first rank in his class.

One cold, rainy morning, John knocked at his pastor's study-door. He had came to remind him that the year of his probation was ended. After daily reflection and prayer, his desire to consecrate his life to the service of the church remained unchanged. From that day he became his pastor's special charge, and was considered almost as a member of his family. 
July, 1821, the angel of death entered the pastor's bright home, and bore away the darling of the household, Cordelia, aged seven months. It was the first break in the family circle. Three daughters remained to bless the home. The following January the angel of life brought comfort and joy to the hearts of the sorrowing parents. A son was born, and baptized John. The healthy baby throve, was fair and beautiful; five months later (June, 1822), after a few days illness, he died, and the second little mound was raised in the cemetery of St. John's.

In September, 1823, a letter from his sister, Eva, Mrs. Dale, informed him that his father's life was endangered by another stroke of paralysis, and that his mother needed his presence. In haste, he obeyed the summons.

October 23, 1823.

To Mrs. Bachman :

"My poor father's health is precisely as it was when I wrote. It makes me melancholy to leave him in this condition, but it seems to be a duty, as he may continue in this state for a month or two. I shall soon be with you, and a thousand times happier than ever to be at home. Even now as I think of it, I am ready to chide the tardy-gaited hours." $*$ * * * *

Childhood's memories of the joyous day of his return home have been preserved. The hearty greetings, and rather noisy welcome of the children. The opening of a barrel of Northern fruit, 
etc. No apples seemed to the little girls so rosy cheeked and juicy as those that grew in grandfather's orchard; and no butter so golden as the produce of grandmother's dairy.

In December, the accounts of his father's health were favorable. Months glided into years, and still the evil day was put off-his father's death did not occur until three years later.

The pastor of St. John's had a keen relish for life. His parishioners delighted to have him share their hospitality; and though he was too busy a worker to spend much time at the table, he gladly accepted a cordial invitation to one of his many homes-and he had almost as many homes as families in his congregation. He scarcely noticed what his hostess set before him; in fact, some of the old ladies assert that he would readily partake of a second dinner. As he was a good talker, full of anecdote and ready, harmless wit, we surmise that he did not always get his full share at the first table, so willingly concluded the meal at the second. Besides, he was a continuous worker, almost beyond his strength, and needed nourishing food to build him up. $\mathrm{He}$ disliked wine, declaring that it never agreed with him; a cup of tea-and a large one-he enjoyed. In his old age, the good wife would return one of his many little jokes, for while he was talking in an earnest, animated strain, she would slily continue to replace the empty cup with a full one, and when the tea drinking was over, have a laugh at his expense, in which he would join heartily, declaring 
that one who had received many cups of tea, of such excellent quality, had the advantage on his side.

In July, 1824, a second son was joyfully welcomed in the pastor's home, and baptized Henry. The joy proved of short duration; the babe was delicate from birth; soon its moans smote the hearts of its parents, and another tiny mound was raised beside the graves of his little brother and sister.

In 1827 twin daughters were born in the parsonage. The young folk of the congregation were delighted. One young girl learned to use her needle skilfully while making twelve beautiful dresses for the pastor's twins, Ellen and Clara. Among sundry useful gifts that found their way to the parsonage, was a dainty straw double cradle; a memento preserved in his family for more than half a century.

Amidst family joys, the tidings came that his venerable father, Jacob Bachman, had been suddenly called from earth. It was a sore grief to him that he had not been present to close the eyes of his beloved parent. The following June, 1827, he prepared to visit the deserted home of his childhood and youth, in order to settle up his father's affairs.

Expecting to be absent for six weeks, he left his church in charge of his student, John G. Schwartz. Another of his home students, William D. Strobel, accompanied him to New York.

They sailed from Charleston, July 27th. The 
family of his friend, Bishop Bowen, were among the passengers; the Bishop was not on board.

\section{At Siea, in Sight of Land, July 2nd, 1827.}

To Mrs. Bachman :

As we hope to be at anchor some time to-night, I write to have a letter ready for the first mail.

Last Friday, a most melancholy scene was presented, which has cast a gloom around us. Mrs. Bowen's daughter. Margaret, who had been very seasick, was taken with convulsions. Every thing was done for her that could be suggested, without a physician on board, but all to no purpose; she died a few hours later. Among the uther griefs of Mrs. Bowen was the thought of being obliged to have her dead child cast into the sea. I felt greatly interested, and we, at last, thought of a mode of preserving the body - a box tightly packed with sawdust and ice.* Mrs. Bowen bore the blow like a saint. Yesterday (Sunday) we had service on board, and I, at the request of the passengers, gave a sermon alluding to the melancholy event. There was great attention, and great solemnity. The crew of this ship is an excellent one. I have not heard an oath or an improper word, and the passengers have been united and attentive. I tried to make myself useful, and believe, in some respects, I have succeeded."

J. B.

When they reached Staten Island, the vessel cast anchor, while he performed the last sad rites for his little friend, Margaret Bowen.

*A fellow-passenger gives the following account: "Through the influence of Rev. John Bachman, the passengers signed a paper, unanimously requesting the captain to dispense with ice during the passage." 


\section{Lansingburg, July 14th, 1827.}

I have slept very little since I left Charleston. On board of the ship, I felt as though I had only dozed, and the stage driver knocked us up at $3 \mathrm{~A}$. M. We traveled over a rough and mountainous country; the roads were dusty and disagreeable; yet I am in excellent health.

My dear old mother is, perhaps, better than I expected to find her. She has the use of her hands, but is obliged to walk with crutches-(the result of a fall.) I fear that she will be compelled to use them for the rest of her days. The old home is shut up. Sister Eva (Mrs. Dale) has taken our mother to her house in Lansingburg. Her girls are charming, and remind me of my own at home.

\section{J. B.}

\section{Fort Plain, July 17th, 1827.}

My Dear Harriet: As I have to-day commenced a journey in a novel conveyance, that of the Tow Boat, on the "Great Western" or Erie Canal, I have concluded to while away a half hour, while we are leisurely moving up Clinton's big Ditch, in writing to. you.

I haye taken this tour, because the executors of my father's estate, will not be ready for a settlement until after harvest; and, because I wish to divert my mind from the melancholy scenes to which I should be exposed, were I to remain for the next fortnight in the neighborhood of my former residence. Early this morning, I took another view of Schenectady. At eight o'clock we went on board of the packet-boat "Albany," and commenced our voyage, (if I may use the expression). The boat is of a very singular construction. It is about seventyfive feet long, carrying eighty tons-ours, however, 
being a packet boat, is only intended for passengers. It has all the conveniences of a steamboat, without danger, and without the noise of the wheels. It is towed by from one to three horses. A long rope is attached to the boat. We are every moment passing boats laden with produce, on their way to the Hudson River. There are already three thousand boats on the canal, and there are hundreds more building. The following is something like a sketch of a boat as it appears when passing up this canal. (Here a pen and ink sketch is introduced). The boatmen have a merry life-no storms, no fear of wrecks, always able to jump on shore, never obliged to wait for a fair wind, able to calculate, to an hour, the time of their arrival at their destined port; meeting every moment with their friends, laughing and joking, and seeming all in a good humor. The boats pass each other almost as easily as wagons in King street, and a boat passes a lock in five minutes, and sometimes in half the time. When we come to a lock, I am in the habit of jumping on shore and picking up all the plants in bloom that appear new to me. The sweetbriar everywhere grows along the canal; the air in some places is scented with a purple asclepias. The elder and sumach are the most common plants now in blossom. The gooseberry is found hanging almost in the water. The black raspberry is most abundant. A beautiful species of purple columbine is clambering among the rocks. The hills are covered with tall trees of the butternut and shell-bark, bending with nuts. The chestnut is in full blossom. The mountain scenery is very pretty along the banks of the canal, as we hug closely the Mohawk River, and are frequently in sight of the main road. In one or two places the mountains rose perpendicularly for two or three hundred feet. Some seemed fairly un- 
dormined by the roins, by tho trickling of water from the springs, and by the winter frosts. Half way up the steops of these rocks which are a formation principally of sand and limestone, you often seo largo holes, like the mouths of vast caves. Tho fish-hawk builds his nest on somo half decayed homlock treo; and where tho bank swallows can find earth, they build their nest by hundreds, and their young aro overywhoro poking out their heads.

Ogdesshuro, on the River St. Lawrence, July $2 S t h, 1827$.

I write in the midst of hurry and bustle to say that wo aro all well, and that, thus far, with tho oxception of a littlo detention, our journey has been a pleasant and an improving one. This is a very boisterous lake-an inland sen. We wero driven into Snckett's Harbor by $n$ gale, und detained for tho greater part of a day, and I was more sea-sick (if I may uso that oxpression of a freshwater lake) than l over was at sea. 'The bont was good, and was mado to stund tho gales on this lake; but the machinery is miscrablo. Every now nnd then wo were obliged to stop and tinker the boiler, and if it had not beon for a fine breeze that lavored us yesterday. I do not know when we should have arrived. Yestorday, however, wo wero ropaid for all our detentions, in the beautiful, romantic views presonted by this splendid river-the St. Lawrence. It has it character peculiar to itself, and no one that ever saw it can forget it. The waters of the lake aro so clear that you can see thirty or forty feet down, and tho shores are, generally, bold and rugged-no weedsno marshes, and seldom low grounds, consequently it is supposed to be more henlthy than some of tho other lakes. Cases, however, of fovor and ague occur 
at somo places, and what is called "Lako Fever," bearing some resemblance to our country fever, sometimes, though rarely, oceurs. The River St. lawrence, contrary to most rivers, which rum south, has a northeasterly course. Its shores aro rocky, and in many cases the water is fifty feet deep, only threo feet from the shore. Indeed, the rocks seem almost perpendicular. 'This river is studded with about seventeen hundred islands, somo of them not five feet wide. A rock rises out of the water to the height of ten or twenty, or even a hundred feet. It has a tree or two upou it, which withstands all the storms and violence of this mighty river. Sometimes it looks like a dining table with an umbrella over it. Sometimes you imagino that a row of stono louses, forming a little village, lies before you; at other times, you fancy there is a mighty castle in sight. You think you seo tho cannon frowning upon you; but it is all a deception, all mado by the hand of nature, and man has had nothing to do with it. The navigation is by no means difficult. There appear to be no sunken rocks, and a man has only to keep his eyes open, and avoid the little islands that seem to float like ducks upon the water.*

In gencral, tho islands and the shore are sterile and there must be hard scratching for a living. Here and there, you seo a $\log$ cabin along the water's edge with a sign hung out on some hemlock tree, indicating that there are accommodations for the voyager-miserable accommodations they must bo. On the Canada side, there are fine farms and orehards, many noble stone houses, and, in some places, an appearance of wealth and plenty; and on the American side, wherever the land is good, clearings aro beginning to be made. Although this is

*'This was before he reached the rapids at Montreal. 
yet a frontier, the time is not far distant, when it will contain a busy, enterprising population.

Tell our little Maria that if she will trace our journey on the map, and give us an account of all the rivers, where they rise and where they empty, and tell us the number of inhabitants in the towns, I shall bring her a fine present.

I have just received a visit and a request, that $\mathrm{T}$ should preach in the Presbyterian Church, as the minister is absent, I cannot refuse.

Kiss all the children for me, and love to the whole row of friends. J. B.

\section{Montreal, Lower Canada, August 1st, 1827.}

I will have much to tell you about Canada, besides some trifles of Indian manufacture to give you. on my return. The difference between the Upper and Lower provinces is very great, both as it regards the face of the country, and its inhabitants. In Upper Canada, you find a soil and people similar to that of the United States, under the same latitude. In Lower Canada, you appear at once to have fallen upon a strange land and people. There is something peculiar in the Canadian character. Those who are nearly descended from the French are a lively, thoughtless set, careless of to-morrow; and particularly the boatmen are indifferent of fatigue, and appear to be happy in their ignorance.

In Montreal, there are several things that strike the attention as peculiar. Their streets are very. narrow ; houses of a dull and gloomy appearance, built of stone, covered with tin, and their doors of sheet iron. This was a fashion in ancient days, when, in the time of the Indians, every man's house was his castle. 'The grey stone houses are 
clumsily built, and, withal, the town has a heavy, sombre cast. The next peculiarity is the number of Indians we everywhere meet with-in the market, in particular. They are full of traffic, and are rather better dressed than I expected. We visited St. Regis, the residence of the Indians-a village with a Catholic Church. There are but two white families in this place.

J. B.

From his Journal. August 9th, 1827.

Left Lansingburg at $8 \mathrm{~A}$. M., in company with my sister Eva, and my sister-in-law, Miss Martin. At Troy, we took the steamboat, and reached upper Red Hook Landing in the afternoon; that night we spent at my uncle S's. He has a charming family; his wife is a model of what a woman ought to be, and the daughters are pretty, amiable and industrious. Last night I slept badly and was feverish.

To Mrs. Bachian.

Lansingburg, August 7th, 1827.

My Dear Harriet: I am longing to be with you in Charleston. The thought of my silent, deserted old home here, is very painful to me.

I have, to-day, had my last meeting with my father's Executors; and I believe that my mother's affairs are so arranged that she will be above want, during the rest of her life.

I will devote the remainder of my time in writing to the children.

To Miss Maria R. Bachman (Aged eleven.):

My dear daughter Maria: I have received your very affectionate letter and rejoice to hear from your mother that you are studious, industrious, and well behaved. 
I thank you for your letter: you will be remembered when I reach New York.

Try ever to please your mother, and then I can cheerfully subscribe myself,

Your affectionate father,

To Miss Mary Eliza :

My dear Eliza: Your letter was a very good one for a girl of your age, I am glad that you promise to write again, and to try, each time, to improve upon the last.

I hope on my return, that your mother may be able to tell me that you have been obedient and in. dustrious. Kiss grand-mama Davis* for me and tell her I thank her for having helped to keep alive our poor little Ellen, (one of the twins.)

$$
\begin{array}{r}
\text { Your loving father, } \\
\text { J. B. }
\end{array}
$$

To Miss Jane Lee Baciman:

My dear daughter Jane: When you are older, and when your eyes grow strong, you, too, will write me a letter, and try to do as well as the rest of the girls.

Tell your teacher to let you have a holiday when father comes home, and give a "howd'ye" from me to all the servants. Your loving father,

$$
\text { J. B. }
$$

To Miss Harriet Eva Bachman:

My dear little Harriet: Your father will not forget you. Be a good girl, and, on Monday morning, quite early, you will get up and say, "father and aunt have come home," and then we shall open the trunks, and then-! Kiss little Julia for me; tell her to learn to talk plain before we come home; and

${ }^{*} \mathrm{~A}$ devoted friend whom the children called Grand-mother. 
say to the twins, father wants them to make haste and grow fat. Your loving father, J. B.

P. S.-Dear Wife: Let chanticleer rather be locked up than give offense to your neighbors. I am sorry for the loss of the geraniums and the ducks; but it would help neither, were I to cry my eyes out, and I hope that you will not make yourself unhappy about these trifling things. My love to your mother, and thanks to all who helped you nurse our Ellen. Remember me to John Schwartz; tell him when he goes to the postoffice to-morrow, he will find a letter from me. Your affectionate husband, J. B.

The morrow came, but did not bring the promised letter. Little Harriet and the rest of the loving household watched and waited-the absent one came not. He was lying ill, almost unto death, in New York, from a fever contracted on the lakes. 


\section{CHAPTER IV.}

\section{ILLNWSS.}

What doest thou? Go on thy way, Thy work thy Lord providing, Thy strength conferring day by day, Thy steps His Spirit guiding.

GHORGE H. BABCoCK.

Extreme ILLNESS From A Fever CONTRACTED ON the " Great LAKES"-EXTRACTS FROM IIIS JOURNAL-LETTER TO HIS VESTRY-JOHN G. SCHWARTZ TAKES CHAPGE OF ST. JOHN'S IN THE ABSENCE OF THE PASTOR.

\section{7.}

(Extracts from Journals.)

August 10th.-This morning, after breakfast, I paid a visit of an hour to Dr. Quitman. I rode a rough-going horse, felt a good deal incommoded, and returned home with a little fever. Before night I grew worse. On the morning of the 11th, fearful that I should become very sick, and anxious to obtain suitable medical assistance, I determined on going immediately to New York. We arrived at what is called the State Dock, in Rhinebeck; but we were a few minutes too late, and saw the steamboat pass. Here I took a bed, having the fever on me. In the afternoon we crossed the river to meet another steamboat. We had a horrid time in crossing. It was raining-the boat was loaded to the water's edge, and crowded with passengers-the ladies were much alarmed, and we were thankful that we crossed over with our lives. The steamboat 
soon arrived, and we got on board. I immediately took to my berth, very sick. About nine o'clock they were obliged to have my sister (Mrs. Dale) sent for, as I had fainted. Here was another trouble. The passengers took fright, and as I had to be led on deck by a couple of servants, they all took to their heels, like a flock of frightened sheep, down into the forward cabin ; but, having occasion to pass through that way as the nearest to my berth, they again took a fresh start. I believe if I had followed them up, some of them would have jumped overboard. When I got fairly into my berth, down came the captain, sent by the passengers, to know what kind of fever I had. I was afraid they meant to land me on some desolate place, and so gave them a full account of all that I had experienced. I heard no more, but spent a most dreadful night. I was glad to see the morning light of Sunday.

August 12th.-Miss Martin had early written a note to Mr. Mortimer, a kind friend, who had been our traveling companion for many hundred miles. He came immediately, and wanted to take me to his house. This I declined, and was driven to Mrs. Waldron's, in Broadway, whose kindness and sympathy I shall ever have reason to remember. Dr. Mott, one of the most skilful physicians in New York, was called in. He immediately recommended cupping-a horrible operation; but it greatly relieved my head - the principal seat of the disease.

13th of August.-I awoke under the impression that my fever was to be of short continuance. That afternoon, however, it returned.

On the 19th, my eye-sight was gone-the whole world was shut up to me in darkness. I tried, sometimes, to convince myself that I was under a delusion; but I soon knew that it was all a sad reality. The conviction flashed over my mind-here your 
earthly pilgrimage is to be brought to a close. It struck me as somewhat strange that I should be torn, at so early an age, from my wife, my children, and my people. But I recalled to my mind how many had, under similar circumstances, been removed from the midst of their families and usefulness, and I ceased to murmur. I had, for some years, made no will. My property had undergone some changes, and my affairs in the North and South, were not satisfactorily settled; but I found my mind was not strong enough to support the investigation. With a heavy heart, I turned my thoughts to my dear family. I had lived with my wife for twelve years. She had been one of the most fond and affectionate of wives. Her life had been devoted to me; and with her I had spent the happiest years of my life. Never had two persons lived more harmoniously; and to die now, far away from her, was most distressing-and then $\mathrm{my}$ seven little children. Where. is the parent who can be willing to part from these, without casting one longing, lingering look behind? But I remembered the promises of God.

Then I began to inquire, Is thy heart right with God? It was a solemn inquiry. I remembered that my life had been far from perfect, and that in $\mathrm{my}$ younger years, I had been rather wild. Still I remembered, too, that I had early commenced the study of divinity, and undeviatingly endeavored to pursue the path of integrity and usefulness. Through the mercy of a Saviour, I hoped I could look forward to the salvation of my soul. But before I had time to go over half the ground, I found an inexpressible satisfaction and joy within. Nothing that this world can afford, can ever be equal to it. There were no forebodings, no fears, no doubts, and I was enabled inwardly to say, " $O$ death, where is thy 
sting, O grave, where is thy victory - thanks be to Gor who giveth us the victory, through our Lord Jesus Christ." I wished for nothing more, and I cheerfully resigned myself, and all that was mine, to that Great Being, who holds in his hands the keys of life and death, and who goes with his children through the lonely grave even to the resurrection of the just.

In the mean time, another physician had been called in. My distressed sister-in-law, Miss Martin, considered it all over with me, and gave the sad intelligence to my family in Charleston.

The kindness of friends, the skill of Physicians. the prayers of Ministers, seemed all to be of no avail, till on the night of the $23 \mathrm{~d}$ of August.

I began to feel an unusual burning in the back of my neck. All night I was in excruciating pain, and, when the light of the morning broke into my chamber,-Great God-I could see! I looked, and looked again, and the light seemed to come upon me, like an angel's visit, to bid me live. I looked around my chamber, and every well known object became familiar. I tried to rouse myself to ascertain whether all was not delusion, but Miss Martin and Miss Cross, came in at that moment, and I saw every feature in their countenances. They noted the change, and their hearts overflowed with joy and gratitude.

Yes, it was the will of heaven that I should live. That I should look again on the charms of earth and heaven; that I should go on the mighty waters; that I should mingle in the family circle, embrace wife and children, and enjoy that heaven on earthdomestic felicity! It appeared to be the will of God that I should again minister to my people, and preach the everlasting gospel to a sinful worldteach truth, integrity, justice, and mercy to man, 
and direct the sinner to that Saviour, whose language is, "Ho, every one that thirsteth, come ye to the waters; and he that hath no money-come, buy wine and milk, without money and without price." "Let the wicked forsake his way, and the unrighteous man his thoughts, and let him return unto the Lord, and he will have mercy upon him; and unto our God and he will abundantly pardon." About 9 A. M., the physicians came in. Their countenances brightened, and I heard Dr. Nelson, whose countenance I now saw for the first time, exclaim: "Now all is safe." From that moment I date my recovery.

August 29th.-I was so much better, that I could be left alone. In the absence of Miss Martin, I crawled out of bed, found pen and paper, and began a letter to my wife, knowing that it would afford her great delight to be told by my own hand-writing that I was safe. I filled my paper, and found that I had yet a hundred things to say.

August 30th.-Wrote to my vestry.-(Letter given later.)-Tried to walk to day-I am very weak.

August 31st.-I felt so much better that I thought I would again write to my wife, and, wishing to say something pleasant to her, $I$ asked a friend and Miss Martin to accompany me to 'Thorburn's establishment for the sale of rare plants. It was near, and I reached there without fatigue. A chair was placed for me, and moved as I wished to change my position. Among the most beautiful evergreens were the India Rubber, with leaves still larger and more glossy than the Magnolia Grandiflora-a Cactus Triangularis in full bud-one new plant from South America, whose leaves, colored by nature, formed a handsome flower; and many other plants. I thought of my wife, but my recent expenses had been so great, that I dared not purchase. I returned home, 
and was able to write pleasantly and satisfactorily to her, and also to my friend, Dr. Wilson.

September 2nd.-God's blessed Sabbath! I woke feeling pretty strong; but my friends thought I ought not to go out. I sent Miss Martin to my friend's, Mr. Schaeffer's, church, designing to keep my chamber ; but I heard one of the tunes sung in my church, and mechanically pulled on my coat, took a little boy with me, and went into the church, as the minister gave out his text. Many pew-doors were thrown open to me, and I was able to remain to the end, without much fatigue. To-morrow, I design to go on a recruiting voyage to New Haven, and other parts of New England.*

\section{I.ET'TER TO THE VESTRY.}

\section{New York, August, 1827.}

Gentlenen: You have no doubt, for some weeks past, heard many melancholy details of my sufferings and danger, and I hasten, at the first moment of returning strength and health, to inform you of the goodness and mercy of God towards me. He interposed in my behalf, when my friends, my physicians, and myself, had ceased to hope, and He has restored my strength, much sooner than any of us contemplated.

I was hastening down to New York in order to sail on the "Niagara," and stopped a night at my uncle's, and another at Dr. Quitman's, in Rhinebeck. There I felt the first attack of a fever, which nearly proved fatal to me. I was fearful I should be very sick, and made an effort to get to New York for medical assistance. That night I nearly died in the steamboat, having fainted

*He did not go to New Haven, but to Newport. 
several times. I was carried next morning, almost insensible, to a boarding-house, where I am at present, on Broadway. After having been cupped, the pain in my head subsided very much. The physician, Dr. Mott, (a kind and skilful man), began to think I should only have a mild intermittent fever, and I yet entertained hopes of sailing in the "Niagara." It is well, however, that she sailed without me; for, had I taken passage on board that ship, I never should have reached the land alive. After a few days, the fever began to put on a more formidable appearance, and to remit no longer. I had a burning thirst, and an incessant and violent headache. I grew every day worse, and my disease begimning to put on a typhoid form, the physician informed us that, if such should be the case, he could no longer be of any assistance. I found, at last, that I could no longer see anything before me; and as this, among the many sick that I had seen, was always a forerumner of death, the conviction came over me that my time was now come, and that my life, chequered with joy and sorrow, with good and ill, was now about to be brought to a close. The thought of my dear and interesting family was a sore trial to me. But I called to mind the goodness of God to many, under like circumstances, and I was comforted by the promise of God, "Leave thy fatherless children, I will preserve them alive, and let thy widows trust in Me."

I then began to review my own sinful life. I found many failings and imperfections for which I implored the pardon of God, through the mercy of my Saviour. But the review of my life, during my ministry, and particularly during the time I was with you, gave me satisfaction. I felt that more might have been done, but still I also felt that, amid the weaknesses of human nature, 
I had endearored to discharge faithfully that great duty of leading the sinner to the cross of the Saviour, and directing my fellow-men to the paths of virtue, integrity, and religion. Ere I had time much further to reflect, a swcet peace, a heavenly calm came over my mind, and I felt a joy which passeth all understanding. It seemed as if some kind angel from heaven had been sent on a message of love and mercy, to cheer and bless me. About this time, my old friend, Dr. Mayer, from Philadelphia, called to see me. I could hear, by his voice, that he was much affected, but I could not see his countenance, and we parted as for the last time in this world. In the meantime, another physician had been called in, without my knowing it for some days. I was still waiting for the determination of the Almighty. I had no wish of my own. Death to those who are prepared does not appear to me to have as many terrors as I once thought. Providence seems kindly to blunt the arrows of pain, and to extract the sting of death. About the fith or sixth day of my blindness, I began, one night, to feel an unusual pain in the back of $m y$ neck. It seems a blister had then taken effect, and the next morning I could see again. I gazed with inexpressible delight upon the light of the sun, and on the countenances of my friends-and now it appeared to me that it was the will of God that I should again go forth in this busy world to discharge my duty as a husband, father and a Christian minister. From day to day I continued to improve.

My friends had kindly watched around my bed in all my sickness-my sister, (Mrs. Dale,) Miss Martin, and Miss Cross never left me for many nights together. Rev. Mr. Schaeffer was with me continually. Mr. Buckley, and Mr. Ralston, (a plan- 
ter from one of your islands,) sat up with me almost every night; and many other friends were unremitting in their attentions. I am now so well as to be able to sit up in an easy chair, and am able to loiter about the room. I know that my vestry and my people will join me heartily in praise and thanksgiving to Almighty God. He will, in all human probability, bring us together again, in health and happiness. My physicians advised me to travel a little into New England to recover my strength, and probably I shall, next week try to leave this noisy city. * * * * J. B.

The anxiety in the Charleston home and flock had been intense. Fearing the worst; all letters were directed to the care of the family physician, Dr. Sam'l. Wilson. John Schwartz deputed himself receiver of these letters, and drove to the postoffice, where he was met by Dr. Wilson.

In one of his letters to the absent pastor, he describes, very graphically, bringing one of these letters to Mrs. Bachman-gives the names of the many persons who had assembled to hear the contentstells of the excitement when it was announced that there was hope of recovery. Several attempted to read the letter aloud, but their voices gave way, finally Dr. Wilson announced the cheering news to the excited group.

During the protracted illness of the pastor, John Schwartz was requested by the Vestry of St. John's to continue his services to the Church. He had preached acceptably twice every Sabbath, lectured in the week, and visited the sick in the congregation. 
Thus he endeared himself, more and more, to the heart of his father in Christ, and to the people of St. John's.

\section{[FROM JOHN G. SCHWARTZ.]}

"'The cheering intelligence has just reached us that you are out of danger.

"I would not attempt to describe my feelings of sorrow during the past week, or of joy at the present moment. You cannot easily conceive in what an awful state of suspense we were placed by the announcement of your extreme illness.

"The tidings reached us on Sunday morning, 26th of August. The congregation were assembling, but Mrs. Bachman had not reached the church. It was decided that it would not do to permit her to find us in such distress; it was agreed, therefore, that I should dismiss the congregation and communicate the intelligence to her, if possible, before she left home. From that time until the present, I have remained almost constantly with her, endeavoring to sustain and cheer her. To add to our distress, the mails were continually failing-now we look upon it as providential, as the tidings in the letters would only have served to extinguish the least glimmering of hope. Dr. Wilson, Mr. K. and myself, were always at the Postoffice when the mail arrived. Through the kindness of Mr. Bacot, the Postmaster, we received our mail before the rest were assorted for delivery; with Mrs. B.'s permis- 
sion, we opened the letters-as crowds of people were anxiously waiting at the door of the office for tidings of you.

"You may conceive the delight I felt last night, when I handed Mrs. Bachman down stairs; she had for a week confined herself to her chamber, in a state of suspense as distressing as it was awful.

"Do not let your mind be disturbed about your family. I need not assure you that I shall do every thing I can that will tend to their comfort. The greatest happiness I enjoy is found in the performance of my duty to you and yours-a duty of gratitude whose obligations I hope to feel as long as I have breath to call you my friend-a duty second only to that I owe to my God and my mother. The circumstances of our late sorrows have made me look upon myself more as a member of your family than as your student. And I know that my feelings towards Mrs. B. were not inferior to those of an affectionate son to the fondest of mothers.

"To every member of your congregation your illness has been an affliction, and your recovery a blessing. I think that I could die easy and happy, if I had such a congregation weeping for me, and praying for my welfare. Though all are anxious to see you again, yet we can bear your prolonged absence more cheerfully, when we reflect that, by it, you will return to us with renewed strength and vigor. I hope to preach regularly twice on Sundays.

"The yellow fever still prevails, and a still more fatal fever on the "Neck." I performed the funeral 
service over Mr. H.-the fifteenth funeral since you left me in charge.

Your grateful friend,

J. G. S."

"P. S.-Your little Harriet says: 'Father got better, because I prayed for him." " 


\section{CHAPTER V.}

\section{7 то 1833.}

Convalescence aNd Return to ChaRleston-A homestead BUILT-DEATH OF HIS TWIN DAUGHTERS-NULLIFICATIONHIS AGED MOTHER-LETTERS.

New. YoRK, September 1st, 1827.

To Mrs. Bachmax :

My Dear Wife: "For three weeks my time has been passed among doctors, nurses, and books; the latter are welcome now. Soon I shall be ready for travel in New England. My doctors came to see me together, about five days ago. They were delighted to find me so well; and the consulting physician jokingly observed, he would not come any more to be laughed at by his patient. They feel rejoiced at the idea of having been the instruments to restore me. They talk of the strength of mind, patience, and cheerfulness I evinced throughout my sickness. The Rev. Mr. Duff, an Episcopal clergyman about my age, was attacked within a few days, and died, when I was at the worst; it was kept from me till very recently. Thus you see, "one has been taken and another left."

Dr. Mott still visits and prescribes for me. I must have given immense trouble to my landlady and friends.

Home, just now, seems to me like a distant Paradise that I cannot reach; but I try to repress the thought. 
I have to write slowly and imperfectly, it exhausts me; yet I find it hard to stop.

Tell my children to obey their mother, and to think of their absent father, who rejoices on their account, that he has risen almost from the grave.

About their health. Should they be taken ill, send for Dr. Wilson. I have confidence in his skill; his attentions, I know, will be unbounded; and if there is danger he will call in a consulting physician. Leave the rest to Providence, and do not make yourself unhappy about them. Kiss them all for me.

J. B.

Extract of a letter to a friend and neighbor in Charleston :

Newport, R. I., September 5th, 1827.

My Dear Gordoy: I arrived in the North in health and spirits. 'Found my poor mother a cripple for life; but her general health has improved. I had a fortnight to spare before I could attend to business, and we concluded, suddenly, to take a trip to the West and North. Miss Martin is an excellent travelling companion, and we picked up, at the start, a most delightful party, that made a journey of twelve hundred miles most pleasant. We travelled sometimes in carriages and sometimes in canal boats-sometimes straight forward, and at other times out of the way to see a curiosity. Sometimes we rested a day, and at other times travelled at night. The eye of curiosity was wide awake. The wonders of nature and art were thrown open before us. The western parts of New York have recently, with a giant's stride, emerged from a wilderness to a garden, and fine towns of brick houses, and taverns, and churches, have sprung up 
like magic, while they are just pulling up the green stumps in the road.

I must be brief, for I intend galloping to Niagara, and through Canada, and down Lake Champlain. I have passed the Hudson, whose shores present monuments of the works of Gorl and the beauties of nature, that will be admired while taste, and feeling, and judgment, remain in the world. The canals are proud monuments of art. Erie and Ontario, have, by this time, mingled their waters in the Great Western Canal. Here boats are sailing on the aqueduct above, and passing under the arches beneath. At Lockport, you rise by eight double locks, sixty-two feet perpendicular; and, on the same principle, you might rise to the top of Mt. Caucasus. One thousand boats are on the canal. In a few years every dollar of the expense will have been liquidated. All this world of produce floats on to the great capital, where men grow giddy, and their hearts proud of their prosperity.

We went to an Indian village, near Niagara, and the chief showed us his drawings-the beltand wampum and battle axe-sold us one of his books, full of fables-we saw an Indian wedding party; the girls went to the village of the groom, reversing our order, for she came to fetch him. He will never be a Jerry, tell my wife and Mrs. Gordon, till he brings his bride to Cannonsborough. We stopped for three days to gaze at the Falls of Niagara. For two days I looked up in stupid wonder, and could not speak. 'Tis folly to attempt a description. Let the sceptic just take his stand on a rock, on the British side, and look up before him and round about, and to the heavens above. The great waters of Erie have been congregated together, pressed into a narrow space, roaring and foaming angrily to be released, and they come with one awful plunge, tumbling down-down 
the dark abyss. The earth trembles, the spray arises up to the heavens, forms itself into clouds, and passes away.

I was led clean under the falls, (the fellow told me as far as man could go), the rushing wind and spray, were awful, and it was dark as midnight. I came away under the impression, that among the wonders of this world, are the falls of Niagara. We passed across Lake Ontario in a sluggish steamboat. The lake was dull. Its shores are yet covered with trees-the axe of the settler is not heard. One long line of dull shore presents itself for hundreds of miles, and we were glad to enter the charming St. Lawrence, with her thousand islands.

In the meantime, botany had been my amusement all through the country. I pulled up every plant in Canada that I could lay my hands on, and Miss Martin preserved the specimens. I found, to my surprise, the Lobelia Cardinalis growing as far as the 46th degree of latitude. The white cedar, which was new to me, is about the most splendid tree I have ever seen. IVe passed through groves of them for miles. The maple and beech, are still the pride of the western forests; and the elms are the largest and finest I have ever seen. The sweetbriar is here indigenous-the whole air in the morning is rendered fragrant by it. The wild rose bloons everywhere beneath your feet, and the gooseberries hang in clusters on the sides of every hill and ditch. In Montreal, we had them three inches in circumference.

We pursued our way down the St. Lawrence, and arriving at the rapids, we all took a boat-about fifteen in number. We went merrily down the rapids, at one place, nine miles in twenty minutesall was life and glee. The Canadians, a lighthearted race, sang, and laughed and jumped. Miss 
Martin gave us the boat song, just as we were going down the rapids; and to this day, we look upon the passage down the rapids, as the most pleasant in all our travels.

Bostox, 13th Sept. 1827.

Tu Mrs. Bachman:

Since I wrote you, I have been sick again. I improved at Newport. Then a cold, chilly wind, from the sea, was too severe for my poor.frame, and I was obliged to order a fire. On Sunday night, I had a tremendous shake, and discovered that I had fever and ague again. On Monday afternoon, we left Newport, in a small steamboat. We had the Governor of Rhode Island on board, a social, well informed man. He called to show us all that was to be seen in Providence: but we had already left the place. In the evening, my chills came on in the boat. When we reached Providence, there were no carriages at the wharf. A stranger kindly went in search of a carriage, and at $9 \mathrm{P}$. M., we rode up to the hotel.

The next morning, I took a short walk to get a glimpse of Providence. A gentleman hailed me. It was Mr M., who had helped to nurse me in New York, when nearly at my worst-to meet me here, so unexpectedly, overwhelmed him with joy. As I was crawling along, a gentleman introduced himself to me, as Mr. G., a son-in-law of Dr. Moser. He lent me his arm, and we went slowly through the town. This town is the second in New England, and has taken away a great part of the trade of Newport. It lies at the head of the bay, and has seventeen hundred inhabitants. Tell little Maria to know all about the geography of this, before my return. Here is Brown University. Provi- 
dence is a bustling, busy town; for twenty miles around every stream is occupied by cotton factories. Immense fortunes have been made by the Quakers; and several flourishing villages, such as Pawtucket, have sprung up within a few years.

I came home, read a little, and lounged about a little. In the afternoon, the fever came on two hours earlier, and I was more or less delirious all night. Poor M. was with me, greatly distressed. They prepared to take me again to New York for medical advice. On our way to Washington, I took tonics, and when we arrived in Boston, at 3. P. M., I felt really strong, and this morning, I am almost as well as I ever was in my life. These fevers return so often, that a man must be continually watching the enemy. Do not give yourself the least uneasiness about me. Soon all will be wellthough I may return to you as yellow as a pumpkin-but, without the ague, I hope. I wish that I could give you a good account of my eyes. The optic nerve was affected by high fevers, it seemed to happen in a moment, at two different times. From this affliction, also, I am slowly recovering. At first I had to be led about like a poor, blind man, now, I walk the streets by myself, and can read all the names on the signs.

To-day, I took a walk with Bishop Bowen. When he heard of my illness, he came from Connecticut to New York to comfort me; but I had left on my eastern tour when he arrived. His family are with him, and have been very attentive to me. The Bishop had left his spectacles; he is feeble and I could outwalk him, and out-see him.

New York, October 1st.

"My good sister, Eva, is with me again; she was miserable about me. It was reported that I was 
dead; and my old friend, Dr. Blatchford, rather prematurely, announced it to his people. Eva did not believe it; yet, to be sure that I am alive, she has come to see for herself. She says Dr. Blatchford evinced much feeling on the occasion."

A man sometimes may hear what the world thinks of him in his lifetime. There were two notices written on the supposition that I was dead; one by Dr. Weston, and the other by Mrs. Rutledge. I have not heard what character they gave megood or bad-perhaps I may as well not hear it.

I have ventured to write, though I cannot read one word that I have written, still I am getting my eye-sight back so fast, that, in a week, I hope to read as well as to write.

To THE SAME :

October 2nd.

I have much to write you, but have only time to repeat a verse to you about my stay in Boston :

"Boston is a dandy place,

The people are all brothers,

And when one's got a pumpkin pie,

He shares it with the others."

I have much to say to you about the elegant houses in the midst of very crooked streets-of South Boston-of Charlestown and Cambridge-the College and the noble Churches-the Mall, and the State House, and the monument going up on Bunker's Hill. Of the kindness of the people, I shall give you a few anecdotes. I had stepped into the reading-room-still half blind-I could not read a word of the Charleston papers; I asked a gentleman to read me the funeral notices; he gave me all the information I needed, and then took my arm, and led me home, and afterwards he inquired after my health every day. 
Once I was picking my way across an alley, by using my cane. A youth passing by, was tripped up by my cane. Both of us apologized. I asked the way to Washington street, and finding that I was lost, he deposited his parcel at a store (he was a clerk), passing his father's house, he ran in for a moment, and brought me two fine peaches, and then conducted me to my hotel-a mile off.

You write me that I am forbidden to come home before a frost. I hope that there is no harm in wishing that there may be a "a black frost" to-night, from Canada to East Bay, Charleston.

J. B.

Dr. Bachman remained in New York until the latter part of November, anxiously awaiting permission to return to family and flock. He hailed with delight the letter from Charleston, announcing a heavy freeze-the greatly desired "black frost," that removed the anxiety of his friends with regard to his return home. He took passage in the next boat that sailed from New York to Charleston, and, in due time, reached his destination. He was welcomed by family and flock, as one whom death had claimed, but the Giver of Life had rescued from the grave. In the sanctuary his people heartily united with him in praise and thanksgiving to God. The pastor could speak to his flock as never before, for, during their separation, he had stood face to face with the "King of Terrors." He had lain passive in the hands of his. God, and had realized that the Master, who had chosen him for a definite work, could yet accomplish all, without his presence and services. But, as he stood in the midst of his peo- 
ple, with a new joy, not unmingled with awe, he realized that God had given him another and a deeper consecration to his life-work-a fresh commission "to lead the sinner to the cross of Christ and to direct his fellow-men into the paths of virtue, integrity, and religion." He spoke in simple, tender, earnest words- "Now is the accepted time," and the Spirit gave its unction to the holy services of that blessed Sabbath.

He had regretted, during his illness, that his worldly affairs were not well arranged; now he endeavored to plan wisely for the future.

Before accepting what he had expected to be a short vacation, he had given out a contract for the building of a comfortable home-his wife desired a roof-tree of their own to shelter their large family. Alas! before the new house could be finished, the twins. Clara and Ellen, not yet two years old, sickened, and, within a month of each other, died. It was with chastened joy that the pastor and his family took possession of their new home.

The years 1829,1830 and 1831 we find were filled up with work for the church, etc., which will be alluded to later.

From Rev. Philit F. Mayer.

Philadeiphia, Aug. 7th, 1832.

I was much gratified by your favor of July 4 th, handed me by Mr. W., who fully confirms your own account of your health and comfort, and superadds his of your usefulness, etc. 
You have been, I think, unusually blessed by a gracious Providence, and I never recollect my agency in prompting your removal to Charleston, without pleasure and gratitude. May heaven long continue thus to favor you and yours! * * *

The latter part of June, our father and friend, Dr. Quitman, was released from protracted infirmities, and great sufferings.

I have reason to be very thankful for the good health of my whole house.

We are, now, practically acquainted with the cholera, and are far less alarmed than we were six weeks since. Here, as in other matters, neglect and procrastination produce the greatest danger. Our ministers, with two or three exceptions, are all at their posts.

Most sincerely do I hope that what I agree with you, is a much greater evil than cholera, Nullification, may be, also, found less frightful, or rather be checked and rebuked into comparative harmlessness, by the good sense and patriotism of your fellow-citizens. * * * God grant that ere long we may have at the head of the General Government a man that will not temporize or truckle from policy ; but, whilst employing all necessary means of conciliation, will, if possible, arrest treasonable designs in the bud.

P. F. M.

During the days of Nullification, John Bachman was a pronounced Unionist in politics. When the excitement was at its height, the Governor of South Carolina appointed a day of "Fasting, Prayer and Humiliation," Religious services were held in all the churches. Many Nullification sermons were preached. A large congregation was assembled in 
St. John's Church, Charleston. The pastor said to one of his students, (Edwin A. Bolles), "I will not disgrace my pulpit by preaching a political sermon." After the opening services, I shall remain in the Chancel and read "Christ's Sermon on the Mount." This he did, with great solemnity, and closed the services with prayer, a hymn and the benediction.

To Mrs. Bachman :

St. Matthen's Parish, Nov. 1Sth, 1832.

My Dear Harriet: When I left home, I was not aware, that there was a Postoffice near, and that we could consequently hear from each other. I find that there is an office where letters are, however, only received once a week. The mail leaves on Tuesday morning, and although this is Sunday night, I expect to be so much occupied on to-morrow, as to be unable to write, I must, therefore, do so this evening, and may add a postscript to-morrow.

We arrived at Bradley's, with great ease, at three o'clock, (the day we left), and at Mr. B.'s, at the same hour on the next day. Found the family all at church-six miles off. They had gone to the meeting of the Synod, which, by mistake, had been appointed a day too soon. We followed on to church; half way we met the family returning, and they insisted on our going back with them, which we did. This proved a long journey for our horse, and I was afraid that we might have injured him; but it proved otherwise, and the horse and master, and, I hope, nistiess, too, are all well.

The Synod met on Saturday, (the time appointed), all the members were present and in good feeling. We accomplished the usual quantity of business. On Saturday, and to-day, we had overwhelming 
congregations. Mealy preached first; I succeeded, with a pretty long sermon; then the Communion followed. After which Mr. Dreher, preached a funeral słrmon over Rev. Mr. Scheck's youngest child, which was buried last week. 'The following is the practice: if no minister is present when a person dies, he is buried, the grave is only filled up even with the surface, and it is not hilled up until the funeral sermon is preached. This is done, as well for a child of a dav old, as for an arlult-and sometimes not until several months afterwards. I was quite pleased with Dreher's sermon; his text was, "The child is not dead, but sleepeth." 'This evening, Hope preached, and afterwards, two of our students lectured, and I was agreeably surprised at their appearance and talents. The truth is, there are now eight or ten young men, who are pursuing their studies, that are likely to be a credit to us, and I am greatly encouraged-their appearance, their modesty, and piety, all please me.

To-morrow is an eventful day with us, as the plan of location for the Seminary will be decided on ; Muller and Dreher are the champions for the two places. They are staying at the same house with me (Holman's), and I have been much amused this evening at the sallies of wit that have passed between them; among the rest, we induced them to let us hear the speeches that they will probably make before the Synod. There is no telling how it will terminate, as the highest bidder will get it. I made my only speech on the subject on Saturday, and do not intend to speak again, if I can help it.

I cannot tell when you will see me; we are full of business, and I can scarcely get to town till Saturday. I am anxious ts hear from home; but shall 4 
have no opportunity. It is one o'clock in the morning - so good morning. Love to all.

Your affectionate husband, J. B.

P. S.-Perhaps it was to humble my pride, that when I opened my trunk this morning, I found that my best coat was not packed up in it, and, as I had rubbed the parsons, last year, about their "Blue and Linsey Woolsey" coats, it was no sinall matter of fun to them to see their President coming out in the old blue-back-pretty well worn, and tolerably woolly from Kunhardt's blankets, which I had wrapped around me on my journey to keep off the cold. However, as it was, there was something venerable in it: the cuffs and the lining, at least, were new. Besides I have heard of those of my cloth who were in a worse fix than I was in to-day. Can you laugh off mortifications? My paper is full.

Monday. The Seminary will be located at Lexington.

J. $B$.

At the close of this year (1832) his beloved and only sister, Eva Dale, was removed by the hand of death. The loss of her only daughter severed the strong link that bound Mrs. Jacob Bachman to Lansingburg. She willingly, therefore, acceded to the wish of her son that she should pass the rest of her days under his roof, and in the spring of 1833 , he went North to bring her to his home.

\section{Lansingiburg, May 27th, 1833.}

To Mrs. Bachuas: I have written to you every thing that I could recollect, and that I thought might interest you ; but a man can always find something to talk about with his friends-and a husband 
can never feel alone, whilst he is conversing with his wife-for writing is conversation.

I am quite well; have enjoyed myself about as. much as a man can be expected to do, who is very fond of domestic life, and who, after a very few days from home, finds the world a busy, bustling scene, in which he feels no interest, sufficient to cause him to wish a longer absence.

I have done what I had to do, and I have attended to my and my mother's affairs, as far as I could. I am packing up all that I think will be useful to her. We leave here to-morrow for New York, and sail in the steamship for Charleston, on Saturday next.

The parting with her early friends will be hard to my mother; but she wishes to come to us-besides, she wants the comforts of religion. I am quite delighted with Dale's children, their attention to their grandmother merits the esteem of every one.

Little Harriet is so great a likeness to our Harriet that I sometimes forget myself, and almost imagine: that I have my daughter before me. There are many inquiries abont you, and sister Maria, and I think, that you would enjoy very much another visit here.

Two days ago I visited the Bald Mountains-certainly among the most splendid views that ever I beheld. Albany, Troy, Lansingburg and Waterford, were so near that it seemed as if I could throw a pebble into either of them-the beautiful Hudson and Mohawk rivers were flowing gently by, as if at my very feet. They were covered with boats and bridges, a dozen villages and a hundred farms, were in my eye at the same moment. The hills and valleys, were covered with green pastures and numerous flocks; the sounds of busy industry and the music of a thousand warblers that chanted around 
me, were borne on the air filled with the fragrance of flowers. Suffice it to say, that although it was a sight that angels might look on with pleasure, yet I would have exchanged it all for one glimpse of my home.

Dear Harriet, you will not hear from me again till we meet. Love to Sister Maria, the children and friends.

J. B.

The roof-tree, at this date, sheltered a family of fourteen, consisting of the parents and their nine children, the pastor's own mother, and his wife's mother and sister. Mrs. Jacob Martin, and her gifted daughter, Maria Martin.

In order that his mother, lame from a fall, should be able to join the family circle, he had a room near the dining room enlarged for her chamber. Soothed and cheered by the tender ministrations of her son and his family, she lived on for many years in placid content-attaining beyond the allotted four score years. 


\section{CHAP'TER VI. \\ $1823-1835$.}

TIIE SYMOD AND THE TIIEOLOGICAL SEMINARY - EARLY HISTORY OF THE LUTHERAN CONGREGATIONS AT EBENEZER AND SIVANNAH-VISITED IBY THE PASTOR OF ST. JOHN'S-FORMATION OF THE SOUTH CAROLINA SYNOD-THEOLOGICAL SEMINARY AT TENNESSEE-SEVINARY IN SOUTH CAROLINA-REY. JOHN G. SCIIWARTZ-ERNEST HAZELIUS, D. D. -THECHARLESTON CHURCI PROSPERS- LETTER FROM S. S. SCHMUCKER, D. D.-DEGREE OF DOCTOR OF DIVINITY CONFERRED ON TIIE PASTOR OF ST. JOINN's.

TURING the period of American colonization, the spirit of adventure and the promise of rich gain lured numbers from the over-crowded population of Europe, to the shores of the newly discovered Western Continent. But the fires of religious persecution brought to the colonies a noble class of emigrants; those who sought, above all, "freedom to worship God." "The war of the Spanish Succession" was instrumental in furnishing settlers for the English Colonies. The Edict of Nantes had been revoked by the brilliant yet cruel Louis XIV. of France. Garden spots on the banks of the Rhine, the peaceful and prosperous homes of the Protestante in Alsace and the Palatinate had been laid waste. The refugees sought an asylum in friendly countries. God moved 
with pity the heart of a woman-the good Queen Anne of England invited the poor Palatinates to her hospitable shores. She ireated them with unbounded kindness, and, hoping to be able still better to provide for so large a number, induced them to migrate to America-the land, that promised work, bread and religious freedom for all. Many of them settled on the Hudson river in the province of New York; some in Newberne, North Carolina; others in South Carolina, principally in Charleston and along the banks of the Congaree, Saluda and Broad rivers. They can also be traced on the Savannah river, Georgia.

The benevolent Queen, generously provided the impoverished immigrants with means to build comfortable homes, and furnished them with extensive grants of lands for glebes, pastorates and schools. They clung to the Augsburg Confession, to Luther's Catechism, and to their Bibles with the Sacraments, for they had brought with them the faith that had stood the test of persecution and martyrdom. Their industry, morality and unswerving faith constituted them elements of strength in the new colonies.

Queen Annie had given them what was then called "The Saxe Gotha Tract," on the banks of the Congaree river. Unhappily, from sickness and the hardships and poverty incident to a life in a new colony, the pastorates and school tracts were scarcely occupied, and this source of wealth was finally lost to the Lutheran Church. 
Leopold, Catholic Archbishop of Salzburg, was also instrumental in bringing valuable accessions of German settlers to America. Driven by fierce eruelty from the Noric Alps in Bavaria, the Salzburgers gladly emigrated to America. The sympathies of all Protestant lands were aroused. The historian, Bancroft, writes, "A noble army of martyrs going forth in the strength of God, marshalled under no banners, save that of the Cross and preceded by no leaders, save their spiritual teachers and the great Captain of their salvation." All Protestant Europe bade them Godspeed.

The Salzburgers reached America in 1734 . Before the Revolutionary war, they had built two churches in Georgia, one at Ebenezer and the other at Savannah.

In 1823, the Pastor of St. John's, received leave of absence from his Church to visit these places, and learn if the congregations still existed. He found that the small building then erected, had been sequestered. (In 1797, the Church at Savannah had been destroyed by fire. On that occasion, St. John's Church, Charleston, contributed $\$ 500$ towards rebuilding it.)

Rev. Dr. Bernheim writes, * "Dr. Bachman's visit to Savannah was not one moment too soon. By means of his well directed and energetic labors, a congregation was organized, and Rev. S. A. Mealy, who had received his theological training from Dr.

*German Settlements in the Carolinas, by G. D. Bernheim, D.D. 
Bachman, became its Pastor. From that time the Lutheran Congregation in Savannah began to prosper."

"Having completed his labors in Savannah, he extended his visit to Ebenezer, for he had learned that though a Lutheran congregation still existed in that place, its aged pastor (Rev. John E. Bergman) was fast sinking into the grave." Mr. Bergman was a learned and exemplary German minister. His son (Rev. Christopher F.) had received a classical education, and had studied for the ministry under his father; but, not being aware that Lutheranism had an existence in the South, he had taken a license to preach under the auspices of another denomination. "This was the source of the most unfeigned regret, both to his father and his father's congregation."

"The discerning mind of Dr. Bachman soon penetrated the difficulty under which the younger Bergman labored, and he was made the instrument, in the hands of God, of giving a new direction to Rev. C. F. Bergman's theological views, thus securing his services to the Lutheran Church, and cheering the last hours of a venerable servant of Jesus Christ."

One of the difficulties alluded to is explained by the Patriarch Lutheran Missionary, H. M. Muhlenberg, in his "Journal." "Rev. J. E. Bergman was averse to the introduction of the English language in the public services, though the spiritual interests of younger generations demanded the change." 
Referring to this period, Dr. Bachman wrote: " The establishment of our church in the South, was a source of greater anxiety to my mind than even the prosperity of my own congregation. I came as a pioneer in our holy cause. There was but a single Lutheran Synod in the Southern States-that of North Carolina, which had recently been organized, and we had no theological school."

The next year (1824), it was proposed that a Synod should be formed in South Carolina; the Pastor of St. John's hailed the prospect with enthusiasm. He was not present at the preliminary meeting; but, at its first convention, he transferred his membership from the Synod of New York to that of South Carolina. It was his privilege, at this meeting, to assist at the ordination of Christopher F. Bergman.

In 1817, Revs. Philip Henkel and Joseph Bell, undertook to establish a Classical and Theological Seminary, in Green County, Tenn. The Tennessee Synod, at its meeting (1818), in view of the great need of such an institution, expressed its satisfaction, and promised its fostering care. "A letter," say the minutes of that year, "was also read, from Rev. John Bachman, pastor in Charleston, S. C., in which he expressed his great desire that a Seminary for the education of Ministers should be established, and assured us that his congregation would gladly contribute towards the support of the enterprise." This pledge was fulfilled. The minutes of the Tenressee Synod for 1819 record " $\$ 221.75-$ a contribu- 
tion to the Seminary from Rev. J. Bachman's congregation."

United action of the church, however, was lacking. From this cause, the institution was shortlived, and in 1820, we hear nothing more of the Seminary in Tennessee.

The pastor of St. John s had sought with fraternal spirit to foster an institution begun in another State; its failure kindled in his heart a deeper

- longing and more determined purpose, that, at no distant day, by the blessing of God, a Seminary should be founded at the South on a firmer basis.

November, 1827, the Synod of South Carolina met in St. John's Church, Charleston. On that occasion, the beloved young Schwartz, gave a report of a missionary tour he had made through the middle and upper districts of South Carolina. His report made a profound impression upon the Synod, and stirred the heart of his father in Christ, who wrote,

"John Schwartz brought to us a far more correct account of the state and wants of the country, than any we had before received; and he has thus, enabled us to see the necessity of renewed exertions to procure ministers, and to encourage our brethren in the interior to build churches and to organize themselves into congregations."

In 1829, Rev. William D. Strobel, (his former student), returned from New York to Charleston, and immediately joined Mr. Schwartz in his missionary work, and their zealous labors were greatly blest.

The necessity for the establishment of a Theologi- 
cal Seminary in the South became every day the more apparent. The failure of the Theological Seminary attempted in 'Tennessee, although it did not daunt his brave soul, yet warned him that united counsel, energy and effort, were absolutely necessary for success. When the Synod met in Savannah, Ga., Nov. 1829, we find him offering sundry resolutions looking towards the establishment of a Theological Seminary. Initiatory steps were immediately taken to carry out these resolutions.

In 1830, as president of the Synod, he again warmly pressed this subject upon the attention of his brethren in the ministry.

"I come now to recommend, with all the earnestness I an capable of, and to implore Almighty God for his blessing on our humble exertions, to institute and support a Tireological Seminary. Hitherto I have had many anxieties on this subject, and great doubts of our success. **-But Providence seems to have removed the greatest obstacles to our establishment of such an institution. Our people have become united and zealous. * * * This united zeal and perseverance will, we confidenily hope, enable us at the next meeting of our Synod, to report that ten thousand dollars have been pledged-a sum sufficient to enable our institutions to go into successful operation; and, although it would have but an humble origin; yet, fostered by our liberality. our watchfulness, and our sincere and fervent prayers, we may, under the blessing of heaven, look forward to a long train of signal blessings upon our Church."

(The amount was subscribed). He continues, 
"It was necessary that a professor to the institution should be elected, and that he should enter at once upon the discharge of his duties. Every eye among the clergy and laity, was immediately directed to Mr. Schwartz. He received a unanimous vote as professor of theology. For a time, his feelings almost prevented the power of utterance. At length, he proceeded to thank us for our favorable opinion; stated his sense of his incapacity to discharge the duties of the position to which he had been appointed; pointed out its difficulties; but signified his willingness to undertake it, by the help of God, and entreated our prayers and intercessions. The youth of the individual, the occasion, the importance of the subject, and his eloquent address, melted the whole audience into tears.

"Unwilling to resign the charge of several congregations in Newberry, until the year had expired, at the suggestion of the Synod, he concluded to secure a house sufficiently large to enable him to receive theological students in his home, until the permanent location of the Theological Seminary."

February, 1831, the Theological Seminary opened with flattering prospects. Professor Schwartz soon expressed his fears that if many more came, they could not be accommodated.

"John Bachman," says one, "was the ruling spirit of the Synod; for eight consecutive years, he was elected president, and wisely guided the counsels of that body."

His ardent desires and bright hopes for the establishment of the Church of the Reformation in the South seemed now about to be realized. 
Rev. S. A. Mealy reported to his spiritual father that the church in Savannah was prospering.

Tidings came from the congregation at Ebenezer, Ga., that their much loved pastor, C. F. Bergman, was doing a great work in their midst.

Mt. Calvary Church, Edgefield District, St. Paul's Church, Newberry, and the Church in Columbia, had all recently been erected and dedicated.

Dark clouds were, however, rising to cast their shadows over this bright prospect.

'The following summer, (1831), Professor Sch wartz' letters tell of failing health. Suddenly he was attacked with a violent fever, which at first apparently yielded to the physicians treatment, but soon returned, with increased violence. Human skill brought no relief, and on the 26th of August, 1831, at the age of twenty-four, the life and labors of this young servant of Christ were closed on earth. His spiritual father wept and prayed while he lingered on the confines of earth, and when the spirit had ascended to God, it was he who preached the funeral discourse that embalmed the memory of the gifts, the virtues, and the attainments of the beloved Schwartz.

Standing at the grave of Schwartz, the tidings reached him from Ebenezer, that another of his spiritual sons, Rev. Christopher F. Bergman had been smitten, and was dead. Revs. Jacob Wingard and Daniel Dreher, all young ministers of great promise, were, in rapid succession, called from the Church militant to the Church triumphant. In 
view of these sad afflictions, as President of Synod, he thus addressed and encouraged his brethren.

"Let our past afflictions teach us humility, an increase of zeal, and an humble trust and confidence in the protection and mercy of God; and, as the hour of night is darkest which precedes the rising morn, and, as the day is often calmest which succeeds the violence of the tempest, so these visitations of heaven, like the calamities that befell the church of old, may be followed by a long train of mercies and blessings to our beloved Zion. But, while we rely for future successes and prosperity on the blessing of heaven, let us do all that lies in our power to promote her best interests."

As he stood in the breach speaking words of hope and cheer, the question was asked him: Where can we find another to fill the vacancy caused by the death of John Schwartz? His reply was characteristic. "While we are endeavoring to find a suitable Theological Professor, let us hasten the completion of the dwelling-house begun for his use, and the recitation rooms for the students." He labored, zealously and sucessfully, to procure funds for the same, and, in a short time, the new buildings were ready for use.

As President of Synod, he wrote to his friend, Rev. Dr. Ernest Hazelius, a member of the Synod of New York, with reference to the Professorship. Dr. Hazelius was at that time one of the Professors at Gettysburg, Pennsylvania; his answer was favorable. With delight, the former wrote "Dr. Hazelius 
has lent a willing ear to the call of the Board of Directors, and will be with us in November next."

Dr. Hazelius was a native of Silesia, in the kingdom of Prussia, and a graduate from a Moravian Theological Seminary in that kingdom. In 1809, he had united himself with the Lutheran Church, and in 1815, was elected Theological Professor at Hartwick Seminary, N. Y. After fifteen years of efficient service, he accepted a Professorship at Gettysburg.Seminary, Penn. In November, 1833, he arrived in Charleston, on his way to Lexington, S. C.

He lingered a few days in the home of the Pastor of St. John's. As they took counsel together with regard to the Master's work in a field of labor new to the Professor of Theology, the hearts of the two were knit together. The gentle, learned, spiritual, but timid and retiring Hazelius turned confidingly to his friend, whose self-reliant nature and buoyant temperament, seemed just the complement necessary for success, in building up the waste places in the Lutheran Church, South. They corresponded and exchanged visits for nearly twenty years, until the death of Dr. Hazelius, which occurred in 1852 .

It is pleasant to dwell upon a friendship so sweet and pure, founded upon mutual confidence and respect.

In $1834,1835,1836$, we find a voluminous, almost overwhelming, correspondence on church matters. Although the Synod of South Carolina and adjacent States had greatly prospered, yet scrious difficulties 
within its bounds, in St. Peter's and other churches, gave its President (John Bachman) deep concern and sore anxiety. It was not until 1837 that these were disposed of, and then only to a certain extent. This, of course, retarded the growth and development of certain congregations. In his own congregation, harmony and zeal prevailed, and consequently, prosperity. "Its praise was in all the churches." Year by year it had been more thoroughly organized. The Alms-Fund, founded as early as 1816 , had, by this time, greatly increased; and societies of active men and women had been inaugurated, in 1825 and 1828, for the promotion of religion, and the education of young men for the ministry.

The membership of St. John's was composed of men of wealth, culture, and position, as well as the poor and humble. They seemed to have been almost of one mind,- - "The head did not say to the foot, I have no need of thee." There was a large colored element-about two hundred negroes. Apparently, the pastor had little difficulty in harmonizing these varied elements in his congregation.

In 1835, Pennsylvania College conferred upon him, the degree of Doctor of Divinity.

The certificate of the same was accompanied by a letter from his honored friend, S. S. Schmucker, D. D., which runs thus:

"In conformity with a resolution of the Board of Trustees of Pennsylvania College, it is my pleasing duty to inform you that the honorary degree of 
Doctor of Divinity was conferred upon you in consideration of your literary aud scientific attainments, and your zeal and activity in advancing the cause of virtue and religion.

"The duty of making this communication has been assigned to me, as I had the pleasure to originate the resolution. It afforded me no ordinary gratification thus to evince the high personal regard and friendship which I entertain for you.

"Having thus discharged my official duty, let me repeat my regret, that I was unable to reach Gettysburg in time to meet you there. I was anxious to converse largely with you on many topics of interest to our Zion; and even supposed that our communion on these subjects might be of future use to the church.

S. S. S."

The South Carolina Synod, in 1833, had united with the General Synod, North. The Pastor of St. John's was elected President of this body in, 1835, and re-elected in 1837 . 


\section{CHAPIER VII.}

1831 AND 1832.

CORRESPONDENCE WITH AUDUBON-NATURAI, HISTORY-A VISIT FROM THE NATURALIST, AUDUBON-IIS LETTERS TO AUDUBON.

"FROM my earliest boyhood," said the subject of $\Gamma$ this memoir, "I had an irrepressible desire for the study of Natural History. At the age of fourteen, I had made an extensive collection of plants, birds and quadrupeds of my native State. I was intimate with Alexander Wilson, the pioneer of American Ornithology, and furnished him with the rare birds existing in the Northern parts of New York. In Carolina, I was enabled to compare the native productions of a Southern climate with those of the State of my nativity."

Now he was to become personally acquainted with Audubon, the Ornithologist. They had, perhaps, corresponded, but did not meet until the Fall of 1831.

We find from the following letter, to Mrs. John J. Audubon, the wife of the naturalist, that Audubon, accompanied by Mr. Lehman a landscape painter and Mr. Ward a taxidermist, had spent a month under his roof. This visit was a beginning of a firm friendship between two scientists, both humble seekers after truth, both close students of nature.

Audubon's grateful and constant allusions, in his 
published works, to the assistance rendered him by "my friend John Bachman," and Bachman's noble defence of Audubon when unjustly assailed as a naturalist, form a beautiful commentary on disinterested friendship.

To Mrs. J. J. Audubon :

Charleston, 1亏th November, 1831.

Dear Madam-I comply with a request of your kind and worthy husband, who laid an injunction on me this morning, that I should write to you. He, together with Mr. Lehman and Henry Ward, left this place this morning, in the schooner "Agnes," for St. Augustine. They were all in good health and spirits, and enthusiastically bent on the accomplishment of the object of their expedition to the fullest extent.

The last has been one of the happiest months of my life. I was an enthusiastic admirer of nature from my boyhood, and fond of every branch of Natural History. Ornithology is, as a science, pursued by very few persons-and hy no one in this city. How gratifying was it, then, to become acquainted with a man, who knew more about birds than any man now living -and who, at the same time, was communicative, intelligent, and amiable, to an extent seldom found associated in the same individual. He has convinced me that I was but a novice in the study; and besides receiving many lessons from him in Ornithology, he has taught me how much can be accomplished by a single individnal, who will unite enthusiasm with industry. For the short month he remained with my family, we were inseparable. We were engaged in talking about Ornithology-in collecting birds-in seeing 
them prepared, and in laying plans for the accomplishment of that great work which he has undertaken. Time passed rapidly away, and it seems but as yesterday since we met, and now, alas! he is already separated from me-and in all human probability we shall never meet again.

I am well aware of all the difficulties your hus band will have to encounter in a wild and, in some respects, an unexplored country. He purposes traversing the swamps of Florida-the wilds of Missouri-the snows of the Rocky Mountains-and, if possible, to reach the Pacific. He will have to encounter not only the climate, but the animals-the savages - the parched deserts of the Southwest-and the snows of the North. But I depend much on his hardy constitution, on his knowledge of the countries through which he has to pass, and on his admirable tact in avoiding and extricating himself from difficulties. But, above all, I have a firm reliance on the goodness of Providence that he will spare his useful life, and enable him to answer the high expectations of his friends and his country.

Mr. Audubon has promised frequently to write to me, and I shall feel as much interested in all of his movements, as if he were a brother, or the dearest friend I have on earth.

I need not inform you that Mr. Audubon was a general favorite in our city. His gentlemanly deportment, his travels and experience, his information and general talents, caused him to be snught after by all. But your husband knew that the great objects before him required his unremitted attention, and he was obliged to deny himself to his. friends, on many occasions, and devoted to them only his evenings.

There seems quite a blank, in my house, since he has gone, for we looked on him as one of our family. 
He taught my sister, Maria, to draw birds; and she has now such a passion for it, that, whilst I am writing, she is drawing a Bittern, put up for her at daylight by Mr. Audubon.

I hope that Charleston may be able to give a few subscribers to your husband's work, and I wish that she was richer, and had taste, and a knowledge of Natural History, to encourage her to do more.

I shall always be glad to hear from one so intimately associated with my friend, and, with the best wishes for his and your prosperity and happiness, I beg leave to subscribe mysélf,

Yours, in great sincerity,

John Bachmax.

To Audubon :

\section{Charleston, Dec. 2d, 1831.}

This moment your kind and interesting letter has arrived. The sails are just hoisted and in a few moments the vessel is expected to be under way. I have run into Mr. K.'s counting house, just to say that we are all well.

I wish that you could have staid with us a month longer; you were scarcely gone, before the birds came from the North, and invitations to you from the planters on all sides for the country. I am sure that we would have kept you, Lehman and Mr. Ward all busy. And with the exception of fish, we would have fed you as well here, as at St. Augustine. All my family talk of you every day-you are still the burden of their song. $* * * * *$

I hope that you will find a new "Stone Curlew," and a Corvus (crow). Indeed, I seriously calculate on your making discoveries. Many inquiries are made about you every day. Dr. Porcher writes, "I see little of Audubon, he lives in the woods." I am in luck, 
friend, since I wrote you, another pair of wild turkeys have been sent me. * * * Do examine into the Migration of Birds-do any birds remain in your part of Florida, that are not found here? I rather fear, that with the exception of "Water Birds," you you will do little before spring.

I have gone carefully over my Ornithology, and have perfected myself in the Fringillas, and. I think that you will not catch me napping on that point-. Would that I knew the Sylvias as well. However, the Spring will do wonders, and we will astonish you with new specimens. You see how I have rambled on $* * * *$ What about that rattlesnake? In Daughty's little work, a scribbler says, "I am afraid of Audubon since the rattlesnake story." I long to read a review of your book in the "Philadelphia Quarterly."

They will not wait a moment longer for nine, so dear Audubon, farewell.

$$
\text { Your friend, J. B. }
$$

'J.he scribbler proved to be Ord, the naturalist, quoting from Waterton, of England.

Bachman, in his "Defence of Audubon," (Bucks County Intelligencer, 1835,) writes,

"Audubon has been rudely assailed about a "snake story," but Waterton has given us several stories that fairly fill us with wonder and dismay. Instead of a contemptible rattlesnake, as thick as a man's arm, he tells us of the great "Boa" which he encountered in his den. Dashing forward headlong upon the Boa, he pierced him with his lance, and tying up his mouth carried him as a trophy to the British Museum. The snake was so large that it took three men to carry it, and so heavy that they had to rest ten times. 
"He gives another snake story - a snake ten feet long. Waterton was alone. He seized him by the tail, the snake turned round and came after him with open mouth, seeming to say. "What business have you to meddle with my tail.' In this emergency, he put his fist in his hat. and rammed it down the snake's throat. Suffering the snake to wind itself around his body, he walked home in triumph. * * * I am somewhat indifferent with regard to Mr. Waterton and his marvelous book; but it is well for the public to know who this champion of truth is, that comes to accuse the American Ornithologist of exaggeration."

тo Audubion at St. Augustine, Florida.

Charleston, Dec. 23rd, 1831.

My dear Audubon: I returned from the country last evening, and concluded to devote this day to rest and amusement, and leave letter-writing and serious studies to another time, but my good wife, and sister Maria, beg me to answer you immediately, and as this accords with my inclination, I have concluded to devote an hour or two in writing to youa brother ornithologist. Indeed, when I heard, whilst in Columbia, that a letter from you had arrived, I felt desirous of hastening my return.

My tour of duty, (Synodical), this year, is over. Everything has gone on well with me-except that we lost a fine horse on the last journey; and the cold killed my wild turkeys. Indeed, it has been almost insupportably cold. I had not time to carry a gun, and on the whole, would not have had much use for it, as the birds were scarce, and it would have interfered with my professional duties. Hares were rather abundant. I saw a " Red Tailed," and a 
"Sparrow Hawk," for some time, seated on the same oak-presently the latter made a dash among some snow birds, and as he was flying away with one, no doubt delighted with the anticipated feast, the Red Tailed took after him, and made him drop the dainty bit, and caught it before it fell to the ground. I found the Solitary and Brown Thrushes, about five of the Wood Pecker family, the Robin, the Rubycrowned wren, and some of the duck family abundant; but there was nothing new-nothing even rare, except a Duck, nearly white, which puzzled me; but as the guns in the house where I was staying happened to be in an awful state, I was admonished not to run the risk of my life in discharging them. This duck may be described; but I do not recollect anything that looks like it in Wilson.

I arrived in Columbia, S. C., almost too late, for the "House" had just resolved that the State was too poor to subscribe for Audubon's work. I felt that it would be a disgrace to the State; and, for the first time in my life, I turned to electioneering. And now, behold me among the back countrymen, spinning long yarns. The thing, however, took, and your book is subscribed for. In addition to this, a party from the interior, has given his name, and Professor Gibbes has hopes that our plan of twelve subscribers for a copy, will secure another set for Columbia. I can, at least, say our prospects are brightening; but I dare not be too sanguine, as I do not want to promise more than I can perform. I have written to G., of Savannah, to interest him in procuring subscribers, and when your book arrives will send a copy to him.

I read what was said in your favor with regard to the "Rattlesnake Story," and thus far, they have not found a wrong twist in your yarn ; but be care- 
ful in describing the wonders of the South and Vest. * * * * * * * *

My wife begs me to thank you for your kind letter which arrived to-day, and she has just given me a little paper of messages, which I am to copy and send to you.

Look here, my friend, before I forget it, why are you always talking of " a load of gratitude"-now suppose we say no more about this. Your visit to me gave me new life, induced me to go carefully over my favorite study, and made me and my family happy. We have, therefore, been mutually obliged and gratified. My wife, sister Maria, and the children, all beg to be reinembered. Tell Henry Ward, that I will never make an attempt at painting, but that I am beginning to stuff birds, and my man, Thomas, during my absence, has done the same. My sister Maria, paints birds better every day; she fails only in setting them up. Your book,* however, will soon be here, and she will study the attitudes of your birds. She is all enthusiasm, and I need not say to you that she is one of your warmest admirers, and, were she not so closely allied to my family, I would say, that the admiration of such a person is a very high encomium.

Am I not a bore to send you such a long letter to a

*'The book alluded to is the First Volume of "Audubon's Birds of America." This valuable gift, bound in fine Russian leather, is still in the possession of the Bachman family. It was the first impression struck from the copperplates, and is peculiarly clear-cut. It was Audubon's travelling companion through England and France, when George $I V$, and Charles $X$, placed their names at the head of his subscription list, on which occasion, Cuvier, pronounced Audubon's drawings, "the most splendid monument which art had yet erected in honor of ornithology." It was no wonder that the admiration of appreciative friends kindled into enthusiasm. 
tropical climate? I have only room to subscribe myself, Your friend,

J. B.

Charleston, Oct. 20th, 1832.

Dear Audubor: This moment yours of the 20th inst. has come to hand, and I hasten to answer it. The book for the South Carolina College, is on board of the vessel at quarantine, and shall be attended to. My sister Maria, has made several drawings, which she thinks of sending you ; but I am anxious to retain them for awhile, in hopes that you may be tempted to come for them yourselt. Ever since you left us, I have been studying up $\mathrm{my}$ Ornithology, in order to be useful to you, and, if 1 am spared, I hope to be so. A month in your society would afford me a greater treat than the highest prize in a lottery. I cannot, I find, feel myself at home with new birds without having the skins to refer to. My cabinet is enlarging every rlay. Henry Ward now prepares the skins-a pair of each. ***I am afraid that our Northern Sylvias do not pass near our sea-coast; I rather think that they follow the mountains; the "Henslow's Bunting" is not rare here; I killed three yesterday, and saw, at least, a half dozen. I shall, next week, write all I know about the Fringilla I found last spring. If you have received my last letter, you will perceive that another new Fringilla has been discovered. I shot it a few weeks ago, and have a skin for you. Maria made a correct drawing of it. I thought at first that it might be the long sought after "Fringilla Canencuta," of Latham, which Nuttall noticed, and which Wilson says does not exist; but which I hope to find. $* * *$ Your Cranes are elegant, but I wish them in the Zoological Garden, as they commenced chasing the children, and I have found it necessary to have them confined. $* * *$ What ducks, that are not 
likely to be obtained for you in Boston, would you like Maria to draw for you? Your second volume promises to be an improvement upon the first. The Brown Thrushes are superior to any thing I ever saw in the shape of birds-but you do not stand in need of my praise!

Write and tell me whether you ever expect to come to Charleston again-that is, are you coming next spring? if not, I fear that I shall never see you again.

It is becoming quite dark, and I suspect that you will be glad to find me coming to a close.

Your friend,

J. B.

\section{To Audubon, at Boston.}

Charleston, Oct. 26th, 1832.

My dear friend: Yours of the 15th inst. arrived yesterday, and I cannot resist the temptation of answering you immediately. In truth, I like to hear from you. I wish to know what you are doingwhat progress your work is making; and, whilst I feel deeply interested for your fame, and the prosperity of a work, which 1 hope, will place the science of Ornithology in the United States on such a footing, that there will be but little left for future ornithologists to do, I also feel a particular interest in your personal welfare, and that of all that belongs to you, I am, therefore, under the impression, that to hear from you, is to write to you-and "nolens volens," you will have to answer. Besides, I want to see you once more to ascertain whether you have stuck to your good resolutions, viz: never to swear, (which is a vulgar practice for one who is conversant with the most beautiful of God's works, the feathered race,) and never to work on Sundays. However, you are now under the tutorage of your 
good wife, and, I doubt not, you are as obedient to her in these things, as you ought to be.

Your request, that I should send the bird-skins, is a natural one, but it cannot be granted all in a hurry. I have several of the skins of the new Fringilla at your service, the rest are carefully set up in the Museum, and Ravenel, a Brother Curator, is out of town. Have patience, for in good time you shall see all. But the stuffed birds must be returned to us, as I have no right to detain them from the: Museum. * * * * You say new birds are scarce. So they are, and yet, in my opinion, we will occasionally find them, for half a century to come. The birds from the West Indies, Mexico, South America, and beyond the Rocky Mountains, will stray among us now and then. Besides, they have their localities. Who sees the Grus Americana in the Middle States? Many of your and Wilson's birds have never been seen but once. Besides. birds that were once rare, are now abundant in some places. Witness the Hirundo fulva. Your new Muscicapa bird was here in our college yard this summer, and I doubt not but her whole progeny will come to hear the boys spout Latin next summer.

I will tell you the plan I have adopted: I try to interest every fellow that has a little brains to look out for new birds. I take him to the Museumshow him our birds and my skins, and then beg him to procure the skin of every rare bird, and if not, at least to send me his wings and tail, head and feet. Be patient, friend, for two years more, and you shall hear what the South and West can produce. Day, Cost, Dr. Strobel, and half a dozen others, are working for you and me.

And now, let your good lady mix you a half tumbler of claret, with a little sugar, and listen to what I have to tell you. I have another bird for you; aye, 
my friend, and one that will interest all lovers of Ornithology. Dr. Strobel brought me from Key West a box of birds-I tumbled and tumbled over the ragged specimens-nothing new, till I came to a little fellow, and what should he be, but a Trochilus, (Humming-Bird,) not yet figured. It is double the size of our Calubris, with a long bill, \&c., but it is in sad order, and I am afraid it cannot be drawn. However, he was knocked from a bush by Dr. Strobel himself, at Key West-so we have now, two Humming Birds.

I have also a little yarn for you about a new pigeon ; but it may be all a mistake; besides, I must always keep something in reserve.

$$
\text { Your friend, J. B. }
$$

To Audubon, in Boston.

Charleston, November 11th, 1832.

I do feel greatly obliged to you for your very kind and satisfactory letter, it is worth its weight in gold to me. It gives me information which I cannot procure with labor or money in this part of the country.

In almost every case, I agree with you. On the migration of birds, my own experience tells me, that you are right, at least, in part-but the matter is still open for observation and inquiry. The new Humming Bird, I believe, to be the "Trochilus Mango," or Mangrove humming bird, described, but not figured, in Shaws Zoölogy. I hope that we may manage to have this bird figured-when I say "we"-I mean "you" and my "amanuensis," Maria. I have nothing new to tell you in the shape of birds-the history of the new birds, as far as I know them, will be faithfully detailed, as soon as I return from my annual (Church) tour, which I shall 
undertake in a couple of days; and then, my friend, I will send you all the birds that I have a right to; the Humming Bird and the Sparrow, and the drawings and skins of the rest. Maria has figured for you the "White Hibiscus," and, also, a red one, both natives, and beautiful; a Euonymus in seed, in which our Sylvia is placed; the white Nondescript Rose; the Gordonica, a Begonia, \&c. She is prepared to send them to you-shall she ship them at once to Boston?

My good wife, and sister Maria, are sitting beside me-the latter is reading your letter, and the former looking on. All are well-little folks and all-and all beg me to remember them to you and yours.

Capt. Day sails from Savannah in a new Cutter; Cost is with him, and I have now a letter, stating their desire that you should join them. They are under the Collector of Savannah; but you will have no difficulty in getting every accommodation. Dr. Strobel sailed yesterday for New York, where he will will remain three weeks, and afterwards settle on the Sinebal Island, Florida. $\mathrm{He}$ has been industricus, bringing me out a box of birds, skinned by himself. Do write to him in New York; he thinks much of you, and will be of service to us. Write, and I shall thank you.

Pluto, (the dog) is well, ears and all, and sends his compliments to you. The cranes are skinned; one is set up in the Museum, and one I have. They became dreadfully dangerous, and long confinement would have ruined their plumage. In the nick of time, when in fine plumage, a few drops of prussic acid did the job. I have a complete history of these gentry - they are great at catching butterflies and sphinxes.

You give me great pleasure by stating what birds you are drawing. You say that you have answered 
all my inquiries, and beg me to make others. You have indeed done wonders. and if you hereafter, do but half as well, I cannot complain * * * * * Your resolution to publish the 3rd. Vol. of Water Birds, you will recollect was partly entered into here, and from that moment, my mind was at ease. It will give you four or five years in advance, and will enable you, in a 5th Vol., to add all recent discoveries of I and and Water Birds. Should you, yet be able to go to Florida and the Pacific, I apprehend that you will extend our American Ornithology to 460 or 470 species, perhaps more. Your sons being able to skin birds and paint them, is a great desideratum-it should be mentioned in your preface to your next volume. The talents of the family combined, (for I know that Mrs. Audubon can write,) will now place the work beyond the fear of falling through, even in case of your death-and the public ought to know it. But you must push for subscribers. If your son Victor can do nothing in Europe, you must go there yourself, and sooner than let the work suffer, you must go on a pilgrimage throughout all the great cities of our Union. Should God spare your life, I want to hear of you enjoying, in your old age, "Otium cum dignitate," and to see your children reaping some of your recompense. Do you not begin to get tired of my long letters? Tomorrow evening I am to read before the Philosophic Society, a description of the new "Carolina Hare." G., has written a review of Nuttall-it is severe and unwise, and I shall try to prevail on him to suppress it. I do not like to see a good fellow put down.

The cholera is on Coles Island-you know where that is-do you remember where we waded over the sand hills on Folly Island? There, a vessel has stranded, with Irish emigrants from New York, with 
cholera. Fifty are dead and lying beneath the sands. I hope that it will come no nearer to Charleston.

My compliments to your son John, with my thanks for his kindness.* 'Tell him I can only repay when he calls on me, professionally, to tie the knot for him-and all shall be done for bird skins.

And now, my friend, farewell! soon I hope to hear from you again-and again to thank you that old friends are not forgotten.

$$
\text { Your friend, J. B. }
$$

To Audubon :

Charleston, Dec. 20th, 1832.

There has not a day passed over my head, for the last two weeks, in which I have not made the resolution, "To-day I will write to Audubon," but I was dull and gloomy (which you will say is uncommon for me). I had nothing to write, but bad news, and I hoped, every day, to see our political atmosphere a little brighter. Do not ask me about birds-1 scarcely know a Buzzard from a King Bird. I will wait until I have had a cup of tea, and then I shall, perhaps, be in a better humor for writing. Now is your time to show your love and charity towards me, by writing me often, although I may not answer immediately. (October 21st.) This is not an answer to your two very kind letters; I hope to make some returns for them, ere long. The first made me laugh for nearly a week, and the other, caused me to say, "I thank you.." I possess none of the bird-skins you speak of sending me; and the Grouse you killed in Maine, I have never seen. I am quite pleased to hear that you have a new owl. By the very first

*At this date he had not met Victor G., or John W., the two sons of Audubon. 
opportunity, I shall send you the new birds and drawings. Nuttall will not be attacked from the South, I hope. It seems to me that he might greatly improve his second volume by holding frequent conversations with you, and he might add, in an appendix, such land birds as you have described, and he has omitted. I have found a few new species of plants that I should like to submit to him. Oh, what an enjoyment it would be for me to escape, just for one week, from the hydra-headed, "Nullification," and sit by your side and talk of birds!

Your friend,

J. B. 


\section{CHAPTER VIII.}

1833.

ADDRESS ON HORTICULTURE-ESSAY ON TIIE MIGRATION OF BIRDS.

THE Pastor of St. John's regarded all God's 1 creatures as humble messengers and guides to lead men to the feet of the Divine Teacher. As he contemplated with the spiritual eye the marvellous works of creation, penetrated with love and gratitude to the Creator he sought to lead others to study the wonderful "Book of Nature."

He was deeply interested, and mainly instrumental, in the formation of a Horticultural Society in Charleston. In 1833, he was requested to follow up his teachings with an address to the Society.

We have selected extracts from the same; yet these lack, of course, the continuity of the whole. Besides, the facts and truths, perhaps familiar to us, came to our fathers and mothers fresh and new. The words, too, fell from the lips of one whose patient, modest and unselfish labors, had won their admiration and respect, To this must be added the electrical presence, voice and smile of John Bachman. 
E.rtracts from un Address delivered before the Horticultural Society of Charleston, on the occasion of its Second Anniversary, in 18.3.3.

Horticulture has two objects in view:

First.-The introduction and cultivation of such vegetables and fruits, as may serve for the food or medicine of man.

Secondly.-The cultivation of trees, shrubs and flowers, which, by their shade, fragrance or beauty, may serve to refine and purify his mind, add to his pleasure, and awaken in his bosom sentiments of admiration to that Being, who, in mercy, has promised, that while the earth remaineth, seedtime and harvest, summer and winter, shall not cease.

Come, let us unitedly engage in studies and employments which will not be confined to the sweets of Flora, or the apples of Pomona; our views will embrace a wider field-a more extended sphere of public utility. Whilst we are introducing new subjects of horticultural industry into our State, we may be able also to diffuse botanical and scientific knowledge, contribute something to ameliorate the condition of the poor, add to the virtues of our people, and lead the contemplation of man from nature up to nature's God.

The advantages of science in horticultural pursuits, do not appear to be sufficiently estimated in our midst. I would endeavor to show you in what way ornithology, chemistry, entomology, and physiological botany, are closely allied to, and inseparably connected with, the science of horticulture. $* \quad * \quad * \quad * \quad * \quad *$ * $*$

Without a suitable knowledge of Ornithology, we are unable to know which birds are injurious, and which are a positive benefit to the farmer; which ought to be banished from our fields, orchards and 
gardens; and which ought to be encouraged there by all the allurements in our power.

The Purple Grackle, in New England, was destroyed in consequence of the Governor's offering three-pence per head; and the result was, that the insects multiplied so rapidly, that the herbage was destroyed, and the inhabitants were obliged to obtain hay from Pennsylvania and England. The poor Wood-pecker is shot by every idle boy, because he is said to extract the juices of apple trees; when, in most cases, he is attracted there by the worm which is perforating the tree; and thus the bird on which the sentence of death is pronounced as an enemy, has come to save the tree by feeding on its destroyer. Let then a sufficiency of Ornithology be known by the cultivators of the soil, to distinguish, in the feathered race, an enemy from a friend. If the hawk, the crow and the starling, are deserving of death for their depredations, let us spare the beautiful warblers-the thrushes, and the wrens, that come to our gardens to claim the worm, and to reward us with a song.

The science of Chemistry advances no inconsiderable claim to the attention of the horticulturist. In order to the successful rearing of plants, we must place them in soil adapted to their natures. The okra, tomato, watermelon, etc., while they grow well in some soils, in others struggle through a sickly existence, and die before they bring their fruits to maturity. As an evidence of what can be effected by a combination of chemical and practical knowledge in the cultivation of the earth, it is only necessary to mention the experiments of the great chemist, Lavoisier. In order to impress on the minds of the people of LaVendee, France, the advantages of combining chemical with practical knowledge, he cultivated two hundred and forty 
acres on scientific principles. In nine years his produce was doubled, and his crops afforded onethird more than those of ordinary cultivators. * *

Entomology, too, a science but little known until very recently, lays a weighty claim to the attention of the horticulturist. We find the earth and the air filled with thousands of living beings, assuming the most wonderful changes, and gifted with the most surprising instincts. Some of these, like the silk-worm, the cochineal, and the cantharides, add to the wealth and luxury of man, or minister relief to his diseases; others are destructive to his prospects, and enemies to his repose.

The oak timber in the royal dock-yards, in Sweden, had been perforated, and greatly injured; the king sent to Linnaeus, the father of Natural History, to trace out the cause of the destruction of the timber. He detected the lurking culprit under the form of a beetle, (Lymexylon navale, ) and by directing the timber to be immersed, during the time of the matamorphosis of that insect, furnished a remedy which secured it from future attacks. * * * A caterpillar of unusual size and singular form, made its appearance on the trees of the Lombardy poplar, in the State of New York, about twenty years ago. Many idle reports were circulated. A dog was said to have been stung by one of the caterpillars, which occasioned swelling and death ; rumor soon asserted that the victim was a child, and the newspapers circulated each idle tale. Now the work of destruction begun-the axe was applied to the ornamental trees that shaded some of the finest streets of the village. The same work of extermination was carried on at farm-houses and gentlemen's country seats, and the stately poplars were levelled to the ground and burnt. The lover of nature remonstrated, but it was vain to contend against the power- 
ful current of prejudice. A little knowledge of Entomology might have satisfied the destroyers of those beautiful works of God, that the larva they so much dreaded was harmless, and that it would soon assume a chrysalis form, and after lying inactive for a short time, would put on wings of a brilliant hue, flit joyously on the air, and live on the nectar of flowers.

But an objection has been urged against this study, which the lovers of science are anxious to combat, viz: that as it requires death to be inflicted upon its subjects, thcrefore they charge us with inhumanity. Cruelty consists in torturing or destroying any living thing from mere wantonness, without a useful end in view. The entomologist does not do this. His insects, by processes which science has taught him, are almost instantaneously killed.

He does not agree with the sentiment expressed by the poet:

"The poor beetle that we tread upon,

In corporal suffrance, feels a pang as great

As when a giant dies."

His knowledge convinces him that this contains more poetry than truth. An examination of the internal system of insects must convince us, that they possess less sensibility than even the tortoise, which is known to walk after its head has been separated from his body. The silk-worm and other of the lepidopterous family, after being deprived of both legs and wings, will not only deposit their eggs, as if nothing had occurred, but will also live on. Besides the period of an insect life, when it is procured for the cabinet of the entomologist, is almost the last stage of its existence. The butterfly would have perished in a few days, and the coleorterous insect would not long have survived. Let 
it be remembered, too, that the specimens which are treasured in the cabinet of a naturalist, which he values more than gold, and on which he thus confers a kind of immortality, by thus being collected, have been preserved from rapacious birds, fish, or insects, which would soon have devoured themmore have been destroyed in this manner, in a single day, than have been collected by all the entomologists in the world.

The cultivation of trees for shade and ornament, should engage a portion of our attention, particularly in our city, where we can thus bring perfume into the air-produce an agreeable shade, and contribute to the health and comfort of our families.

Our vegetable gardens might, particularly in the winter and the spring, be made among the very finest and lucrative in the world. Many of the vegetables which, in Europe, are raised with great care and expense in hot houses, thrive and flourish with us in the open air.

The Strawberry, a fruit that has always been a favorite, is well deserving of the attention and encouragement of this Society. Some of them cannot endure the heat of our summer, whilst others seem scarcely affected by heat and moisture. It is more than probable that we may find varieties adapted to the soil of every garden.

The Mulberry tree is easily cultivated-our soil and climate are admirably adapted to its growth. Some of those that were planted by the first German Missionaries at Ebenezer, Georgia, during the time of Governor Oglethorpe, are still in a flourishing condition. The culture of the Mulberry ought to be more attended to in our Southern country. The time may not be far distant, when the reduced prices of cotton may render the raising of silk, particularly the raw material, one of the staples of the South. 
It is now believed that many portions of the pocrest pine-barrens in our middle districts, are admirably adapted to the culture of the grape. In the neighborhood of Charleston, many varieties for the use of the table are produced.

The forests of Carolina abound in a vast variety of beautiful trees and shrubs, which we ought to transplant into our walks and gardens. Is there a tree in the world more worthy of admiration than our Magnolia Grandiflora, the majestic native of our woods? Our Azaleas, Phlox, Scarlet Lobelias, Jasmines, Honeysuckles, etc., give to the woods of Carolina a charm, which not only fills the heart of the lover of nature with delight, but causes even dullness to pause, wonder, and admire.

The God of Nature has cast our lot on this teeming earth; let it be our task, to do all that in us lies, to render this earth the abode of comfort and of peace.

If we do not give to man that which is profitable in a pecuniary point of view, we should remember, that every txtra tie and enjoyment makes a man's home dearer to him. The vegetables which he has raised with his own hands, in his own garden-the tree and vine which his wife and his children have assisted him in planting-the fruits which they. have admired and relished together, and the flowers which they have reared with mutual care, all will serve to strengthen the bonds of conjugal, parental, and filial love."

In 1840, the Horticultural Society was so well established, that it offered premiums to competitors. We hold in our own hand two large, heavy silver medals, (greatly prized by the recipients). They bear the device, "Fructibus Decora." One was 
awarded to Mrs. Bachman, for the best specimens of indigenous plants, the other to Rev. John Bachman, for the best specimens of cauliflower.

Dr. Bachman had also employed his few leisure moments in preparing an Essay entitled, "The Migration of the Birds of North Anerica"-a subject that had attracted his attention from boyhood. The paper was read before the Literary and Philosophical Society of Charleston, March 15th, 1833. It was afterwards published in one of the scientific journals.

We give a few extracts:

"For ages past, the migration of birds has been a subject of great interest to naturalists. The mysterious appearance and disappearance of many species, at different periods of the year; the remote or unknown situations to which they retire; the sudden appearance of some birds in the spring, after one or two days of warm weather, and their equally sudden disappearance on the first cold day; all have conduced to create many vague and superstitious notions in the minds of the uninformed, and have often left the intelligent student of nature in perplexity and doubt. * * All are agreed on one point, that there is a wide field open for inquiry and observation. The works of God, amidst the wonders of nature, are always worthy of investigation.

Very little has been written on the migration of North American birds; a topic probably regarded of too little importance to meet the research necessary to a satisfactory result of such an intricate subject; for the elucidation of which, I have myself possessed 
some opportunities, by witnessing the migration of birds, in three very distinci portions of America

That instinct is truly mysterious, which, at particular seasons of the year, teaches birds to take wing and leave their native haunts, pursuing their onward course, sometimes across arms of the sea, over mountains and forests, into far distant countries. It is equally surprising, that many of them, beginning their migrations in summer, should thus anticipate the cold; while others return from Southern climes, before the snows of the North have disappeared, and whilst winter still "lingers in the lap of spring." * *

Whatever difficulties there may be in accounting for that mysterious principle called instinct, which induces birds, at certain seasons, to change their abode, and, after an interval of six months, to return to the neighborhood where, the year before, they reared their young; the fact of these migrations is uncontrovertible, and the reasons why they take place are becoming more and more apparent. Those birds that migrate, are from the very structure of their bodies, admirably adapted to rapid and continued flight. Their feathers are so light, that they float in the atmosphere for many hours with very little artificial support. The tubes of these feathers are hollow; the bones are specifically lighter than those of quadrupeds; the bones, also, are hollow, and instead of marrow, are filled with air. They are furnished with lungs of an unusually large size adhering to the ribs, and provided with aerial cells. insinuating themselves into the abdomen. These, added to great length and strength of wing, enable them with ease and rapidity, to navigate the air-to elevate themselves above the clouds, and pass from one country and climate to another. * * From a variety of accurate experiments, which have been made at different periods, it appears that the 
Hawk, the Wild Pigeon, (Columba migratoria,) and several species of Wild Ducks, fly at the rate of a mile in a minute and a half; this is at the rate of forty miles an hour, nine hundred and sixty miles in twenty-four hours. This would enable birds to pass from Charleston to our distant northern settlements in a single day; and this easily accounts for the circumstance, that geese, ducks, and pigeons have beeen taken in the Northern and Eastern States, with undigested rice in their crops, which must have been picked up in the rice fields of Carolina or Georgia, but the day before.

The story of the falcon of Henry II, is wellknown; which, while eagerly pursuing one of the small bustards at Fontainebleau, was taken the following day, at Malta, and recognized by the ring which she bore.

Swallows fly at the rate of a mile a minute. That many birds continue their migrations by night as well as by day, may be easily ascertained from their notes, which in autumn and spring, the seasons of their migration, we often hear by night. 'The great Whooping Crane scarcely ever pauses in his migrations to rest in the Middle States. I have heard his hoarse notes as he was passing over the highest mountains of the Alleghany; but he was always ton high to be seen by the naked eye. This bird seems to take wing from his usual winter retreats in the South, ascends into the higher regions of air (where less inconvenience is experienced from darkness,) and scarcely halts until he arrives at his breeding places, in or near the polar regions.

Birds migrate, either to avoid the cold of winter, or to find more abundant food. I am induced to believe that the latter is a stronger principle than the former. $* * *$ Those immense numbers of birds that feed on insects and worms, all migrate to those countries where they are abundantly supplied with 
this kind of food. These are the Swallows (Hirundo), the Night Hawk and the Whippoorwill (Caprimulgus), the fly-catchers and warblers. To them, migration is essential to the support of life. Insects at that season disappear; the earth is bound in frost, or covered over with snow; but long ere that, these lively tenants of the air, have obeyed the impulses of a mysterious instinct, and have migrated to more congenial climes.

To these, we may add all birds that obtain sustenance from fresh water ponds and rivers. These, finding the Northern swamps, brooks and shores, frozen over, migrate to milder regions, where they can procure suitable food. Those that gain a subsistence from the sea, are not obliged to migrate, as the Gulls, Petrels and Puffins, etc. In addition to their warm covering, they are supplied with sacs, containing an oleagenous substance, with which they lubricate their feathers, thus rendering them impervious to moisture. While floating on the surface of the water, they often draw up their feet beneath their warm covering of down, and thus every part of their body is protected from the influence of the cold.

There is another circumstance that ought to be taken into consideration, with regard to the capacity of birds to endure cold. A large mass of air penetrates the lungs and all the aerial sacs and canals of the bird, thus increasing the action of the heart and propelling the tide of circulation with great rapidity. The pulsation can scarcely be counted, and the temperature of the bodies is as high as $106^{\circ}$ Fahrenheitthe heat of the body enables them to bear with ease, the rigorous cold in the distant north, and in the elevated regions of the air. * * I have seen wild pigeons in immense flocks in Canada, in the coldest winters, when the thermometer was below 
zero. It is to be remarked, that the previous autumn had produced an abundance of beech-nuts and buck-wheat-their favorite food; and that the ground was not yet covered with snow. It is only when the forests of the West have failed in their usual supply of mast and berries, that the wild pigeons come among us, to claim a share of the acorns and berries of our woods, and the refuse grains scattered over our rice fields.

When the period of migration arrives, birds evince an uncontrollable restlessnesss of disposition, as if conscious that an important undertaking was at hand. I have kept in my aviary, roluins, finches and orioles, that had been procured when. young at the North, and no sooner did the Spring, (the time of migration) arrive, than they exhibited, by their constant fluttering, a disposition to escape, and the moment this was affected, they flew off, not to the South or West, but as directly in the line of migration, as if guided by a compass. These are facts of which the humblest person may inform himself, but which neither our wisdom, nor our philosophy, can explain.

The lover of nature who, in the seasons of the migrations of birds, sees flock after flock passing over his head, all day long, or witnesses the wrens, bluebirds and creepers, stopping just for a few minutes to seize a worm or an insect; if he listens at night will hear unusual sounds. The single sharp note of the rice-bird repeated all around him, is succeeded by the crake of the snipe, resembling the grating of a wheel, repeated at long intervals; and the Woodeock (Scolopax minor), wheels around him uttering notes like the loud ticking of a watch, so rapidly repeated, that they cannot be counted. The bird ascends higher and still higher in the air, like the lark of Europe, till he seems to have risen 
above the clouds, when, suddenly his voice is hushed, and, in zigzag lines, he descends rapidly to the earth, and alights near the spot from whence he arose. This is repeated for several successive evenings, and at early dawn, till, suddenly, he begins his annual migration and is seen no more. The Yellow-crowned and Night Herons utter their hoarse croak as they pass high and rapidly on ; and at a still greater distance is heard the, not unmusical, cry of the Canada goose. In the mean time the Rails, Owls, Thrushes, Warblers, and many other birds, glide silently by the observer, like spirits of the air; and without being superstitious, there comes over him a sensation of admiration and fear; and he feels the truth of the language of inspiration, "Great and marvellous are Thy works, Lord God Almighty."

The arrival and departure of birds, affords a pretty sure indication of the state of the weather, and the advance of the seasons. Living constantly in the air, and exposed to all its variations, they become, either from instinct or habit, acquainted with the changes of the atmosphere, with the winds and seasons. When the well known notes of the Whippoorwill are heard, the farmer is reminded that the time for planting corn is at hand. The Fish-hawk's return to the rivers of the North, is regarded by the fisherman as a proof that the season for taking shad has arrived. When the Swallow appears, the danger of frost is believed to be over; the Cuckoo of Europe is hailed by the old and young, as an evidence of the return of Spring.

"Sweet bird, thy bower is ever green, Thy sky is ever clear;

Thou hast no sorrow in thy song,

No winter in thy year."

The inhabitants of our Middle and Northern States should feel equally, interested and pleased 
when they hear the soft and melodious notes of the bluebird, the robin, and the wood-thrush, reminding them that "the Winter is past and gone, and the time of the singing "bird has come."

Previous to a storm the birds give indications of its approach. Our Vultures in great numbers rise in circles till they are almost lnst in the region of the clouds, the stormy Petrels (Thlassidroma Wilsonii, Bon.) crowd in great numbers around vessels, and follow in their wake, as if seeking the protection of man; the Seagulis and Terns make the shores re-echo with their hoarse, clamorous notes, and the Barredowl (Strix nebulosa) utters his funereal cries even in the day. But when fine weather is about to return, the whole scene is changed, and every hedge, copse, and grove is rendered vocal, and the whole feathered tribe seem to rejoice in the anticipation of bright skies and sunny days.

My subject is far from exhausted, but I am admonished to bring these desultory remarks to a close. If I have succeeded in throwing even a ray of light upon that which has hitherto appeared mysterious in nature; or if I have been enabled to awaken, in a single mind, a sentiment of admiration and gratitude to that superintending Providence. who teaches the stork in the heavens to know her appointed time, and the turtle, and the crane, and the swallow to know the time of their coming, I shall feel doubly recompensed for those pleasing studies of nature which have enabled me to offer these remarks.

The farther we pursue this subject, the more we shall be convinced that in nature there is a wise arrangement which governs instinct and action, and which creates being, beauty, and happiness. The laws by which the whole system of nature is governed, are equally simple and majestic, and are 
equally visible in the minutest, as well as in the most stupendous of God's works. From the beauty and harmony of the system of nature by which we are surrounded, the mind is sensibly led to admire and adore the mighty Cause-the Fountain of wisdom and perfection, the Unseen but Everpresent, Who is the source of all matter, mind and modes of existence.

The temple of nature, wide and wonderful as it is, stands ever open, inviting all to enter and learn lessons which are calculated not only to enlighten the mind, but to improve the heart. The chief object of science and philosophy should be to lead to the altar of the benevolent Author of ali things, and to make all our experience and knowledge subservient to His grand designs. 


\section{CHAPTER IX.}

\section{2 то 1835 .}

Labors in Natural History.

LETTERS TO AUDUBON AND HIS SONS-SUCCESSFUL LABORS IN BOTANY AND NATURAL HISTORY-ANECDOTE OF OEMLER THE ENTHUSIASTIC BOTANIST-THE VISIT OF AUDUBON AND HIS FAMILY-MR. EDWARD HARRIS, OF MORRISTOWN, N. J.-A NIGHT WITH THE HUNTERS AT LIBERTY HALI.

To Audubon:

Charleston, January 20th, 1833.

My Dear Friend: For some weeks I have been unwell, and for a few days in bed. I shall endeavor to-day, as I am up again, to amuse myself in writing to you.

Your last letter required a Philadelphia lawyer to decipher it, all pothooks; you must have taken lessons from some new-fangled writing-master in Yankee-town, who has taught you to place the letters, as Henry Ward sometimes does his birds in a basket-heads to tails and crosswise. * * * *

Now for a rambling letter about birds. I have not used a gun more than once this winter, but, hope to do so again-when I regain my health. Dr. Strobel has gone to Sinebal-a portion of Florida where you have never been. Leitner, the Botanist, leaves here on an expedition to Florida. Many of us have subscribed in shares, to receive the amount of our subscriptions in any collections in Natural 6 
History that we may desire. My nephew, Dr. Martin Lee, has lately returned from Alabama, where he expects to settle as physician and planter. He informs me of a very large Hare in that State, living in the swamps; and also, speaks of a large brown Squirrel. I have just given him some arsenic, as he starts to-morrow morning, and he will send us on every thing that he conceives to be new. $* \quad * \quad *$ * * * * *

Before I forget it, you cannot form an idea how acceptable a couple of skins of the "Variable Harc," - would be to me. I have already added one Hare to the Fauna of the United States-hope to add another very soon, and I want the skin of your Northern one to make comparisons.

Henry Ward is still at Santee; he has set up a number of Ducks and Hawks, together with a Deer, Turkey, Eagle, etc. He goes next week to the seashore for Gulls and Sea-ducks-as yet, he has found nothing even rare.

Our winter has, as yet, been moderate, and we have not had the usual Northern birds.

I should not like you to publish a single error, if you can avoid it, and therefore express my fears that the "Blue-headed Pigeon," may not frequent any of the Florida Keys. I have, as yet, found no one who ever saw them there; and, as you did not kill any of the birds, you might possibly have been mistakenyour reputation is worth more than a dozen new species of birds. But, oh! if Captain Day, with his "Revenue Cutter," could be sent round to the Pacific, what a harvest would be in store for you.

I rejoice at the success of your work in Europe and America; if you live to complete it in the same style in which it has been commenced, there will be fame for you and your children.

I have been trying to send sister Maria's drawings 
together with a few bird-skins to you by land, but no opportunity offers ; and, as she has only one more to draw, I shall send them by water.

Tell your kind son, John, to show his good will to me by putting me up a few bird-skins. I am told that he does not particularly like bird-skinning; tell him that he might have a worse employment. How great a blessing is a wife and sons, if they are clever. I fancy you like a king giving general orders in your old age, and your family, like Ministers of State, executing them.

I have hardly room left to add my name and to say. that,

I am, your friend,

J. B.

John Audubon sends the skins and writes his first letter to his future father-in-law. We give the reply.

To John W. Audubon :

Charleston, February 28th, 1833.

I received your welcome letter, and before I had time to answer it, your generous present arrived. I write this evening to thank you, in great sincerity, for this act of attention and kind remembrance. To show you how much I prize the bird-skins, let me assure you, that I had not a single one in my collection of the kind you sent, and, some of the birds, I had never seen. I have examined them over and over again; I have labelled them all ; and they will always remind me of the father and son to whom I am under many obligations. You sent me one more bird than your list specified - the Golden-Eyed DuckI suppose to show, that a generous man will do more than he promises.

I hope that it will give no offence to old Mr. Jostle, if I just add, that notwithstanding his elegant 
copper-plate, his son writes a somewhat better hand than he does himself. There is room, however, for improvement in all of us, and the time may come, when he may be so superior in that department, as to set up a patent. Writing School, to teach the whole system in one lesson, and perhaps, by that time, $I$ may do the same in drawing.

You certainly underrate your talents as a stuffer of birds-indeed, they are the best skins I have in my possession, and I only wish that I could do them as well-even Henry Ward acknowledges that you are his equal in this art.

I am anxious to feel myself at home in every part of Ornithology, so that I may be able to review my old friend's "Second Volume." In two or three weeks we will know the result of the agitations of Nullifying brethren-for weal or for woe; and should affairs terminate favorably, I shall be able to go on with a little more spirit, in my studies of Natural History.

Yes! I am always ready with or without book, to fulfil my pledge, and many a poor fellow has found to his cost, that I can tie a knot that no Jack-knife can sever.

What chance is there of my ever shaking you by the hand? Will the flowers of spring and summer be over, before I obtain even a promise?

Tell your good father, that if he is not too tired of my long letters, he will hear from me, perhaps, too soon. In truth, when I am dull, (and I never have known what low spirits were, till I witnessed the heart burnings of political strife), I begin to write a letter to my old friend, Jostle, and after two or three lines, all care and sorrow are forgotten.

Perhaps, I ought to be ashamed to make one other request about bird-skins, after your generosity; yet I would add a list of Northern birds that I 
cannot get here, not that I wish you to put yourself to one dollar's expense, or any unnecessary trouble. But, I have thought, that when two good shots crack over the birds right and left, you may now and then come across one that would suit me-that old Jostle may not want, and that young Jostle may not find of too unpleasant a savor to skin. I only say, If they come in your way, remember me; if I never receive a single one more, I have no right to complain. Now what in return shall I do for you in the way of skins? This is the land of Cranes, will they be of any use?

Just ask your father, whether he remembers Chisolm's Pond-when I missed, I always had for an excuse, that my gun was too short, and when he did so, he always said that the Cranes were a quarter of a mile off. We are all well. Our best respects to your parents; I shall always be glad to hear from you.

J. B.

\section{To Audubon :}

\section{Charleston, January 23d, 1833.}

My dear Audubon-In most cases I have to apologize to my correspondents, for my neglect in writing; I must now apologize for writing so often. In fact, I have been seriously sick, and mend slowly. I want something to amuse me, and while I am writing to you my mind is cheered, and I can, almost fancy myself enjoying over again, the happy hours we spent together-they were, the happiest of my life. Do you not remember, as if it were yesterday, with what triumph we brought home the first "Blue Herons?" With what a shout we made the forest echo, when we picked up the "Yellow-crowned Heron," which you were so anxious to draw ; and how we rejoiced when, after taking so wide a toul 
over the "Charleston Bridge," we, at last found out where the "White Cranes" fed; how you cheated me out of a shot; and how we hung up the fellows by their long necks on the bushes.

I am very much gratified to hear by yours of the 11 th, inst., that your son Victor arrived safely, and that he is doing well in England; and that your work is prospering. You are aware that I have always had some fears that your work, (so very expensive), might embarrass you in a pecuniary point of view. Your son being an active man and acquainted with business, may be of immense service to you. If pecuniary difficulties are overcome, (and I trust that they will be by active exertions, ) your work may be completed, even though you should not live to give it a finishing hand. In a very short time, you will have drawn the greater part of the known American Birds, and you have very judiciously and carefully written their habits. There are many who can put them together in histories. Since your last visit to England, you have done wonders. The drawings you have made, and the information collected from Florida, Carolina, Labrador and New England, are invaluable. No Ornithologist in the world has enjoyed all the advantages which you have possessed.

When I spoke of your obstinacy, I meant it as a compliment, and I am glad that you understood me; and yet you are not as obstinate as your predecessor, Wilson, who was ready to quarrel with a man because he differed from him in opinion. I liked Wilson because he studied nature; I like you because you give theory to the dogs; because you give to the opinions of others just as much as they are worth; because you will examine and judge for yourself, and because you study, where every Naturalist ought, in the wide field of Nature. How differ- 
ent is her teaching to that expressed by men in general. I have read the speculations of men, I have listened to the tales of the ignorant traveler, and it seemed as if there were defects in all the works of God. Then I have turned to the fields and woods; to the air, the earth, and the sea; and I perceived that all was order, harmony, and beauty, and I have acknowledged that all the defects wcre in the shortsightedness of man. $* * * * *$

That you will be obliged to begin with the "Water Birds," after the second volume of the "Land Birds" is finished, is an event that I conceive inevitable. It will take many years to finish your work. Before that time a number of land birds will be discovered which are now unknown. What land birds may not be found in Florida, along the borders of Mexico and the Pacific! I am also inclined to believe that you may yet wish to include the birds of Canada. Under any circumstances, you cannot possibly include all your land birds in two volumes; but, surely, your subscribers would rather have a perfect work in the manner proposed, that have some post mortem pubiication like Ord's supplement volume to Wilson, in which the reader has to lament, at every step, that the author had not lived to save his work from the murderous hands of a friend.

I scarcely know what answer to give to your questions-soliciting advice with regard to your travels in the Spring; but I will say something to convince you that I have thought on the subject. The only reasons why a visit to the coast of Labrador might be advisable, is, that you may be able to complete your dissertations on the habits of the Ducks, Gulls, etc. This would certainly enable you to say more with regard to the habits of our water birds, than has ever been written before; for it cannot be disguised that little, as yet, is known of water birds- 
and their histories are just as interesting, if properly investigated, as those of the land birds. * * * If your visit to Labrador is indispensable, you had better go in the Spring. Florida has not yet been sufficiently explored. Leitner, ${ }^{*}$ and others, who are on the look out, may enable you to procure additional treasures from that interesting portion of our country. Austin Settlement, although not a part of the United States, is yet settled by our people; there you might travel in safety and obtain many new birds from Mexico. *** I do not wish you to go to the Pacific, but when you go, be as well prepared as you were on your visit to Florida; go with a company. $* * *$ A faithful search along the coasts of the Pacific and the banks of the Columbia, and the valleys west of the Pacific, ought to take two years, or at least not under twelve months. There is a passage by canoes into the Northern Lakes, but there is scarcely a resting place; the traders suffer sadly, and they would not stop to let you kill even a "Bird of Paradise." I hope to live to hear you tell many a good yarn about your adventures in the land of the "Black Foot Indian" and the "Grizzly Bear ;" yet, before this, let your mind be niade easy by finishing your work as far as it can be done. You see I have come to no conclusion; but I dare not be more particular.

Friend Audubon, how many Gulls have you drawn? the number in Bonaparte startles me. ** Your last birds, like the leaves of the Sibyl, will be most valuable, because they will be hard to obtain.

*Dr. Leitner was an enlightened, highly educated and skilful German physician, who afterwards accompanied an expedition sent to Florida by the United States to keep the Indians in check. The savages took Dr. Leitner's scalp as a trophy - the dead body was not recovered. His death was a loss to science and humanity, as well as to friendship and kindred. 
See how I have run on-are you not glad that my sheet is filled?

Best respects to wife and your son John, in which I am always joined by my family.

$$
\text { Your friend, J. B. }
$$

\section{To Audubon, directed to New York City.}

Charleston, March 13th, 1833.

My dear Audubon: I received your very affectionate letter a few days ago, informing me of the safe arrival of the box containing Sister Maria's drawings, \&c. I feel grateful for the expressions of esteem and friendship which your letter containsallow me to add, that my family and myself receive no letters which are more welcome, and none are read with more avidity than yours. And, now, since there is a probability that our correspondence will, in some degree, be interrupted in consequence of your contemptated visit to the coast of Labrador, a selfish feeling almost induces me to wish that you might change your mind and remain nearer to us. But there is so much interest thrown around one who undertakes a long and dangerous journey or voyage, that he seems to rise in importance, and seems to awaken additional affection, in proportion to his dangers, and the length of his absence. I must then say, in God's name-Go, and may success attend you.

Sister Maria feels grateful to you for your too flattering opinion of her efforts. I take it, however, as a compliment to myself, inasmuch as though I did not use the brush, I occasionally gave advice generally ; however, after the drawings were finished. In answer to the question, did she execute the drawings? I have only to say, "all that she did not do, were done by your humble servant." 
Friend Audubon, it will save me a long letter of empty, dry descriptions, to say to you that the only three birds which you have in Maria's drawings, and of which you have not seen the originals, were shipped two days ago on board of the Saluda packet for New York-and it is a chance if the ressel does not outsail this letter, as even our roads have declared for "Nullification." You will now have all the skins before you-judge for youself, and amend Maria's drawings, if you wish; but, when this is done, have pity on me, and send the three last birds of the Sylvia back again; or else the "Philosophical Society" may think that a certain Parson and $\mathrm{Cu}$ rator does not know the difference between meum and turum.

Well, friend "Jostle,"* the new birds have made you scratch your head-I fancy I see you rummaging up some of the neglected lumber in the store-house of that capacious brain of yours-you have more experience than your poor firiend, but I think, when your letter comes, it will tell me that I was not far from the mark in the first four birds that I described and that the other three can only be known by a comparison with the stuffed specimens of birds which they represent. ** * * * * *

$\mathrm{O}$, this abominable Synopsis! It is only calculated to confuse. Have you seen specimens of these birds? May not Cooper, of New York, have them? or may not "Bonaparte's Vol. of Water Birds" be so far underway, as to enable you to make comparison? All beg to be kindly remembered to you and yours. Your friend, J. B.

*After Audubon's first visit to Charleston, we find the name "Old Jostle" applied by John Bachman to his friend J. J. Aurlubon, and Young Jostle to his son John, or Jostle No. 1, and to Mr. Victor Audubon, Jostle No. 2. Those whocould have given the origin of these names have passed away. 


\section{Charleston, September, 14th, 1833.}

Hail! my old Friend, all hail! Health, success and happiness, attend you-the winds, the waves, the heavens and fortune, have all smiled on you. Welcome, thrice welcome, to the homes and hearts of your friends! Long may you be spared to be the honored instrument of giving to the world the figures and the biography of that beautiful feathered race, that seem to acknowledge you alone as worthy of commemorating their forms and their histories. Your letter from Halifax has made me quite happy. I am like a boy that has just heard of a month's holiday. I have just read your letter aloud at the dinner table-all rejoiced, and even my old mother, was much interested; all, even to the youngest, send their good wishes, respects and love to you.

I congratulate you on your new discoveries. * * I long-long to see these new specimens. A Parus! a Finch! a Muscicapa!-where does the last bird go to in winter? A new Rat! a new Bat!-God bless us ! I am almost crazy! I am glad that Harlan is off-for now I shall come in for the four-footed beasts.

There is scarcely any use in beginning with my yarns in this letter. I proceed to the subject-this lies nearest my heart. You must pay me a visit this autumn; you must just pay me a visit. Bring, if you can, the wife and son; you shall all be welcome-doubly so; but you, I must see. You cannot go to Florida-there is no use to go in the winter; you must finish your next volume of biography. Stay in the Atlantic States this winter, and when the Blue Bird carols his earliest song in Spring - then off to Florida, Arkansas, or the Pacific.

I shall write you again in a couple of days. Remember me to young Jostle.

Your friend,

J. B. 
The invitation was accepted by Audubon and his son, John Waterhouse Audubon.

We find many letters during this next year (1834), from botanists, especially from Oemler, an enthusiastic German, at that time residing in Savannah, Ga.

Bachman tells us that on one occasion they were botanizing together; his companion strayed away, and at length he discovered him, on his knees, thanking God that he has found a new plant.

Dr. Harlan and Charles Pickering, of Philadelphia, were already among his correspondents in America, and letters from scientists in England and Germany, all attest to his successful labors in Botany, Natural History, etc.

Dr. Harlan wrote in $\mathbf{1 8 3 4}$ :

I am honored by placing you among the most favored of my correspondents, and feel myself abundantly indebted to you for the interesting facts and valuable hints contained in your last. Excuse the liberty I have taken in reading several extracts to the "American Philosophical Society," at its last meeting. Your letter attracted much attention, and gave rise to an animated discussion. I found that you were already very favorably known to Dr. Vaugn, and other members. I shall not fail to profit by your observations in my next edition of the "Fauna Americana."

In 1835, Audubon was in Europe, publishing his "Birds of America," while Bachman was at home closely studying, in his hours of recreation, the skull and the habits of the Buzzard and Alligator. 
The friends had much to communicate to each other. Occasionally, Bachman discovered a plant or bird that had not been described, and mutual rejoicings followed.

He wrote enthusastically to his friend:

My Dear Audubon-"Your Second Volume is decidedly superior to the first-it is indeed beautiful. The plates of the Water Birds do you credit. I rejoice over them. You will reap fame, if not wealth. Friend Audubon, you must not praise me so much in your articles. I give you fair warning. I have no objection to being referred to with regard to the habits of some birds, but, anything more, will induce me tō score you well

Your references to your learned friend John Bachman, $D$. $D$., are all humbug."

- In September 1836, a mild form of cholera was prevailing in Charleston. Audubon had just returned from Europe to America.

Charleston, Sept. 14th, 1836.

My good old friend-How greatly do we rejoice to hear of your and John's safe arrival in America; although not a Prophet, you predicted the very day of your arrival. There is no one whose society, in these days of anxiety and distress, would be more dear to me, and prove a greater cordial to my dejected feelings, than yours, but as it is, we cannot see you for several weeks to come.

I received, yesterday, your first letter by mail, and to-day, another by steamer. Your very fine dog arrived safe, and is now kicking up a dust with "Nell" in the yard. The latter is a perfect beauty 
and staunch as a rock, in fact, she runs like the wind and outdoes herself.

Do try to keep, at least, a pair of pigeons for me, I greatly long for them. Dr. Wilson and sister Maria, have several elegant mocking-birds for you. I hope that, by this time, you have received a list of the birds collected for you. * * * * * I am not surprised at your having gone to Philadelphia. Who could help it, when a dozen new birds were in the way? Several are already published by Wilson, Cooper and Swainson; these surely, you will be allowed to figure-you did the same for Wilson. The new birds, they will probably describe in some Journal-all this is fair. But after that, surely, they will let you figure them.

Capt. Day is on the Florida coast. I gave him your large gun and a keg of whiskey, to put up specimens. Dr. Leitner is among the "Keys." I gave him my own gun and whiskey for specimens, With regard to Florida, nothing will be done by Naturalists for at least two years. Your Indian friends, the cut-throats, have scalped almost every woman and child south of St. Augustine, save those on Key West. They have burnt and plundered every plantation; and aithough they will probably be, in a great measure, put down next Winter, yet there will, undoubtedly, remain many small predatory bands that would make no bones of scalping an Ornithologist secundum artem; and would ask no questions whether he was the friend or enemy of William Penn. Of Texas, I think better; and thither, or along its borders, you may, I think, venture-for the Texans are our friends. I suppose Genl. Gaines will keep the Comanches quiet.

Now for the health of the city. We are very anxious about the Cholera. We know not what a night may bring forth. I will defer until to-mor- 
row what I have to say on this distressing subject. * * * * *

Thursday, September 15th.-The Cholera has, indeed, made its appearance among us; there are mitigating circumstances about it; yet, being a new disease, and destructive of the life of certain descriptions of persons, it has cast a deep gloom over our city. The disease is confined principally to our domestics, and the irregular among the whites. My own servants have nearly all been down in succession. My daughter Eliza was slightly attacked, but now she looks as blooming as ever. As regards my own health I mend but slowly from rheumatism. If I were not so much engaged and exposed, professionally, I should recover faster. I am weak in my limbs, and, like an old man, I use a cane.

I shall write you again by this boat. All unite in love to you, and to John.

$$
\text { Your friend, J. B. }
$$

'To THE SAME:

Charleston, Sept. 17th, 1836.

I commenced writing to you on the day of the steamboat's arrival, and added something to my letter every day; when finished, the girls blotted the superscription in clapping on their new fangled wafer; and then sister Maria laughed at us all. As the steamboat does not go for an hour, and many thoughts are crowding into my mind, I write to you again.

The reports of Cholera are daily more favorablestrange that in a city like ours-far South, and crowded with subjects, it should not have carried ruin and misery along with it. But it has proved far otherwise; as yet, not a respectable, temperate white, that I know of, has died; and even among our domestics, the most careless and irregular only, 
have been cut off. Some, indeed, are of the opinion that it is not Asiatic Cholera. I think otherwise. The state of collapse can scarcely be mistaken; and those who have died have, nearly all, fallen into this state before death. Fortunately the disease did not appear among us, until it had traveled through the North and West. Our people were not much alarmed, but remained at their posts, watching the first symptoms, and checking the disease before it had put on an alarming character. During my confinement I read everything that I could find written on the subject, and became a quack myself. Dr. Harlan's reports I found most sensible, and his writings have raised him, in my estimation, as a Physician of excellent judgment. My family are all well again, excepting my mother's white servant, and she is better. Relapses in this disease are exceedingly common; even a cup of tea, or a piece of bread, sometimes causes the patient to lose ground. * * * *

Before I go further, let me tell you that one of the evils of my late indisposition, from which I recover but slowly, is, that I cannot hold my hand steady ; after writing for ten minutes, I have to lie down and rest a little.

While you are detained at the North, there are some matters to which it would be well for you to attend. Find out in what quantities and how far North our long-billed Curlews are found and migrate. William Cooper ought to permit you to figure the "Mourning Warbler." He did not say, "No," when I asked him, but he did not say, "Yes." $\mathrm{He}$ was under obligations to Bonaparte then, and he distinctly said that if that work was discontinued, he would be willing to give you all the assistance he could render. I am not sure that you have, as yet, figured the Grey Owl of Maine. You must find 
out his habits and those of the Hawk. The Fresh Water Ducks we can easily get here; and you need not trouble yourself about them in the North, but remember the Sea-Ducks you must procure in Boston and New York. When you come among us. we will talk over every bird in your collection, and at the end of your next Letter-press, you will show what true greatness is, by doing all in your power to correct every error, and thus to place our Ornithology where it should be. $* * *^{*} * *$

Our young Anhingas and Caraca Eagles are in elegant order. Come and converse with them.

Tell John that we will make the time of his absence as short as possible-a little while longer, and, God willing, we shall take you both by the hand.

I must close, or the boat will be off. In great haste.

I remain as ever, your friend, J. B.

John W. Audubon was at this time engaged to Maria R., Dr. Bachman's eldest daughter.

To Audubon :

September 23d, 1836.

As you in your last complain of not hearing from us, I will begin a letter to-day, and add to it to-morrow, before the steamer leaves.

* * *

My family, since I wrote you last, have been well, except myself. * * My system was debilitated, my exposure was great, and it was not surprising that I should get an attack of Cholera. I was ill and then had a relapse. Dr. Wilson, fortunately, happened to be in the house at the time. The second attack, as it was attended with great coldness of the extremities, was rather more alarming than the first. It yielded, however, to the usual remedies. I am now 
sitting in my study, with your three large Books of Engravings near me, while I am writing. I suppose that I shall not be allowed to go out for a couple of days; I am a little salivated, and what is singular enough, I have lost all my lameness. Hitherto I had been obliged to limp and use a cane, and now I walk without one, and feel no pain. So you may set it down that Cholera cures Rheumatism. But I have talked enough about myself.

Let me once more urge you not to come to Charleston before you are bidden; sister Maria, who is at my elbow, adds "before you are welcome," so you see you might stand some chance-and John too, of being turmed out of doors. I have taken a great fancy to Edward Harris,* could you not bring him with you, and let him join our old fashioned party? What a treat! Please inform me what has been his success with the Curassow birds? My Pheasants had several fine young ones, that could fly to the top of the fence. When I was sick, alas! they suffered the dogs to kill them. The Cormorants are in fine order.

*

J. B.

\section{September 30th.}

We hope soon to have it in our power to remove the embargo, and the old ship and tight little schooner may sail boldly into port, without lying at Quarantine. In other words, you and young John may, ere long, come and feast your appetites on specimens of tough beefsteaks, dry rice and hominy. I think I see you coming from town as hungry as hunters. "Bless my soul," say you, "I am almost starved to death," and the beefsteak like

**Edward Harris, Esq., Morristown, N. J. 
a tough hide of an alligator will rise like Banquo's ghost before you. I fear that you will both be as lank as Greyhounds, the week after your arrival. But I forget that one of the party can easily feed on love, and that we have besides, at least, a dozen jars of old birds in whiskey, which may serve for the two old naturalists. The truth is, the country folk are afraid to come to the market-vegetables are forbidden; fish and shrimps are thrown into the dock. We will have to stay our appetites by talking about birds. Oh, what a feast! Why we will devour every bird on the Pacific, beginning at the great Condor, and leaving off at the new Humming-bird-which I hope has been re-discovered.

* *

The birds have arrived after a long passage. The pigeons, you know, I am fond of. Dr. Wilson longs for a Jay, and I will send it to-morrow. The boxes of plates have arrived; they are, to my eye, the most beautiful engravings that I have ever seen. * *

I am getting quite well again, and will soon be able to out-walk you. Sister Maria has not been able to paint much for you, within the last month, having been principally engaged in nursing the sick.

Old friend, I have not heard from you for some time, where are you, and what are you doing?

Your friend,

From Miss Martin to J. J. Audubon.

$$
\text { J. B'. }
$$

Charleston, October 28th, 1836.

My dear Friend-Your welcome letter did not reach Charleston for more than two weeks after it was written.

Dr. Bachman has quite recovered his health and activity, and is anxiously looking forward to the time of your arrival. We have given our neighbors warning not to be alarmed if they hear a tremendous 
uproar in our quiet domicile, as we know that when you arrive, his expressions of joy will be rather boisterous.

When you are seated by a comfortable fire in our little study, I shall show you something that will prove to you, that, though absent, you were not forgotten by your friend, John Bachman.

I do not wonder at the satisfaction of your subscribers with your Third Volume, it is, indeed splendid! You must be merciful to me, and excuse me for having done so little for you in the painting line, I hope soon, to assist you. When you are here, I will be quite at vour disposal-I will be your amanuensis, painter or any thing else that will be an assistance to you; not forgetting the darning of socks, which you know was my employment on a former occasion, during the absence of your good wife. My sister, and all the young folks send their love.

Accept, my dear friend, the assurance of the warmest regards of

$$
\text { Your affectionate friend, M. M. }
$$

P. S.-Dear Audubon-I have not heald that any persons recently arrived here, have taken Cholera, I doubt if you and John would be subjects for it. I believe that this letter will not reach you at the North-and I hope that you will come ahead of it.

Have you the common House Wren? if not order it, and let us compare it with ours now here, which may be your Wood Wren; I am anxious about this matter. I wrote you at Baltimore and shall probably not write again.

These are awful times in money matters, but of this, you will hear enough when we meet. Every one, nearly, has failed, but the Parsons and Ornithologists-Why? Because they have nothing wherewith to fail. In haste, Your friend, J.B. 
Audubon his wife and son, accompanied by $\mathbf{M r}$. Edward Harris, arrived in due time.

Hunting. fishing and botanizing, were the order of the day.

The plantation of Dr. C. Desel, his hospitable home, Liberty Hall, Goose Creek, near Charleston, was a favorite resort for the friends.

It is a cold night in December. Let us throw back the heavy chintz curtains, and look within. Great blazing logs are in the open fire place, lighting up the whole room. The antlers of deer captured in the chase, adorn the walls. The hunters seated around the fire, are jubilant over the splendid luck of the day.

It is an interesting, happy group before us; Audubon, with his massive forehead and his waving, dark hair-slightly touched with gray-worn long, and flowing over an ample, white collar; his nose aquiline; his mouth well formed; and his beautiful, eagle eye full of animation. Bachman, with his noble countenance, and genial flow of thought and word. Mr. Edward Harris, the tall, refined, cultivated gentleman. Dr. Wilson, as trim as shiny boots and well brushed coat could make a successful practitioner. John W. Audubon, with his compact, well developed body, and his handsome face-brimful of fun. To-day he has killed his first deer, and, according to ancient usage, was blooded-that is, was marked on the face with the warm blood of the newly killed deer-(a ceremony decidedly more enjoyable to the old hunters, than to the one under- 
going the ordeal). They have already partaken of a substantial supper, and are talking over the sport and triumph of the day. Two noble bucks and a doe have been brought home, swung across the front of the saddles. According to plantation etiquette, the deer taken belongs to the fortunate hunter, whose shot brought him to the ground. Therefore a fine supply of venison and game is secure, not only for the Pastor's table, but for the sick and delicate in his flock, who will share in the spoils of the chase.

John Audubon is making a suggestion - that every one of the company be required to prepare a verse for a poem to be sung to a time-honored Southern ditty: "Clare de kitchen, old folks, young folks, OldVirginny nebber tire." The proposition is received with applause. This is 'Thursday night: Saturday the Parson must be at home, therefore the poets must finish their verses by Friday evening. The vote is given, by acclamation, that John Audubon, who has a reputation in that line, should be the minstrel. The next morning is a rare occasion. Quite a little company have assembled from a neighboring plantation. At the wide-open door, appear the ebony. smiling faces of Sambo, March and others who kept the deer stands, etc., yesterday.

Without delay, John Audubon appears in his hunter's dress, horn at his side and violin under his chin.

The first verse is laudatory of the hospitality of the Master of the Ceremonies, Dr. Desel. In the verses 
that follow, the hits become more and more telling, until the sound of the fiddle strings is almost drowned by the laughter and applause. The whole company join in the chorus. John Bachman's verse describes a long, tedious, and remarkable ride taken by young John on a hard-going horse.

"Young Jostle, he mount on "Mossa " big hoss, And he look so fine, we took him for Boss, But soon he began to ride more sideway than straddle, And to beg for a sheep-skin to put on de saddle.

Chorus-Clare de kitchen, ole folk, young folk, Old Virginny, nebber tire."

The closing verse was composed by young John himself-it told of the Parson's search after the long coveted "Short-tail Rat," and his joy over the discovery of the same. At that moment the minstrel pauses, and points with his violin-bow above the door, and there, to the great surprise of all, hangs a veritable rat, with the prescribed short-tail, quite visible ; young John's clippers having secretly transformed the tail of a common long-tailed rat into the new species.

The slumbers of all that night were deep and sweet. On the morrow the friends take leave; and with light hearts our party beguile with merry chat the homeward journey to Charleston. 


\section{CHAPTER X.}

\section{7.}

\section{Bachman and Audubon.}

UNION BETWEEN THE FAMILIES OF BACHMAN AND AUDUBONTHE HOME-LETTERS TO AUDUBON, AND TO HIS SON, JOHN W. AUDUBON-VISIT TO BALTIMORE-LETTER TO MR. EDWARD IIARRIS-FAILING HEALTH.

$W^{\mathrm{E}}$ find from the following letter, that the union between the families of Bachman and Audubon, was at hand.

Charleston, May 14th, 1837.

My Dear Audubon: I write you in haste, and am uncertain if this letter will reach you before you leave Louisiana. You are aware that I have to visit the North the latter end of this month, on business connected with the Church; this you know, must be attended to before Ornithology, or even Matrimony. I go in a day or two to Norfolk, and hope to be once more in Charleston by the latter end of June, which I conceive to be about the time when I may look for your visit to us.

We are all well. I am terribly hurried, and my letter must be short. I have received the fullest information about the Flamingoes; and the eggs themselves, I hope to get before your return. I also found the nest of the Carolina Titmouse, etc. * *

You are aware from a former letter, that your Quadruped skins were wrecked off the Florida Keys. By good fortune they were recovered and sent back 
to me-but awfully soaked with salt water. They, however, enabled me to judge what they are. * * All join me in best wishes.

Your friend,

J. B.

John W. Audubon and Maria R. Bachman, were united in marriage in 1837. They joined the rest of the Audubon family in New York, and in August sailed in a packet ship, bound for Liverpool. It was only after a long and tedious voyage, that they reached their destination.

This first break in the Pastor's family circle weighed heavily on the parents' hearts. Bachman wrote to Audubon, "I have looked forward to this event very much as a man does to a funeral." Rapid ocean transit, the cablegram, etc., have now brought the land beyond the Atlantic comparatively near to us. Fifty years ago it was far different.

We have had already glimpses into the parsonage. Maria, the eldest daughter, at the time of her marriage was twenty years of age, and Eliza, the second daughter, nearly nineteen. There were, besides, five younger daughters and two sons-in all, nine living - and five in God's acre.

The pastor of St. John's believed in faithful, early training and instruction-yet, there were few rules for family government. One we rememberno child absent from morning prayers without an excellent reason, was permitted to sit at the large breakfast-table-the culprit had a seat assigned at a little side-table. By a singular accident, however, if 
it were an accident, when a child was late at prayers, the study door was left a little ajar, and the lazy little sinner often slipped in softly, and knelt at mother's or father's side, knowing well, that if the "Amen" had not been said, all was safe-the morning kiss was still secure, and the hated seat at the side-table left vacant. Father, with a twinkle in his eye, would say, "Escaped by the skin of your teeth." Later, mother gave her gentle admonition, "Child, did you remember when you were lying in bed this morning, that your father was up and hard at work?-don't be late again." Who could resist such an appeal? Father would take the children to his bee-hives and repeat to them from "Watts' Songs,

"How doth the little busy bee, Improve each shining hour."

He would tell the interested group, how the lazy drones were stung to death by the busy workingbees, and show us how the instinct of animals amounted almost to reason. When the children asked if the working-bees were not excessively cruel, he would smile and quote: "If a man will not work neither shall he eat," and counsel the little people to take the busy ant and not the lazy drone, as a model.

In the flower garden there were two large aviaries connected by a covered way. A daughter remembers that when she was a little child, something had sorely ruffled her temper; her father snatched her 
up in his arms and carried her to the aviary. The gentle birds answered his call; but the Pouterpigeons extended their breasts, and, with sullen notes, strutted about. A little story followed, that interested the child, and made her feel greatly ashamed of her ill temper. Many such lessons he gave to the children in a series of stories, that appeared later in one of the religious journals.

He was the chief promoter of fun and frolic among the children; often he would come home at twilight, and before the lamps were lighted, call to the eager little people to join him in a Deer Hunt.

$\mathrm{He}$, as the swift old buck, took the lead in somewhat leap-frog fashion, and the children who represented the pack of hounds, followed in close pursuit. Before long, the tired deer was brought to bay by one of the hounds jumping nimbly on his back; then, above the din, a hunter's horn would be heard, to announce that the merry chase was at an end.

This was the home so dear to the Pastor of St. John's.

To his son-IN-LAW, John W. Audubon, in Jondon.

Charleston, August, 1837.

My dear John: I suppose that by this time you are hard at work doing something to keep want from the home; and this, they say, will keep the little "God of Love" from flying out of the window. Maria, I am sure, will be prudent and industrious. Her education and habits are such as will, I think. render her an assistant, as well as a blessing, to you. A part of my boy W's prayer every night is, that 
the Packet in which sister Maria sailed might arrive safe. Say to your brother Victor, that I thank him for his letter, and will answer it soon. By this time, Maria may have seen half of London. We expect to hear all about it soon.

Yours affectionately, J. B.

Charleston, August 16th, 1837.

My dear Audubon-Although you wrote me a long letter before you left New York, yet I did not receive it until last Sunday. I call it a good letter, because it was not a few lines written in haste; but a careful, thoughtful letter. My family have been writing by every packet; but, if we are to judge from the letters we receive from England, they are likely to be very irregular and long on the way. * * - I flatter myself, that by this time you are all safe in England; usefully employed, and therefore happy. Since you left us, there has been a dulness and lethargy, as if something were wanting. We are trying to fill up the time: Eliza and sister Maria are studying German. Botany has been commenced by all the girls, and they are devoting more time to music than formerly

I have been intolerably lazy since you left us, confining myself entirely to my parochial duties, and scarcely doing anything else-seldom even writing a letter. I have put up for you a few birds in rum. Your list, alas! cannot be filled here; but I will do what I can * * By the way, Judge Lee has just informed me of a fact which agrees with my theory, that Buzzards obtain their prey by sight, not by scent. In the upper part of this State, a hog had fallen and died under the edge of a bank; the stench was so great, that it nearly drove the visitors from their boarding house; and yet the Buzzards' noses were not keen enough to find it out. 
My application to the Matanzas has been successful-a gentleman went forty miles, and procured the nest and two fresh eggs of the Flamingo. The eggs are white, the size of that of the goose. I shall send one of them to you, and the other to friend Brewer. I have a pair of young ones on the way, in order to ascertain the time required to bring the bird to full plumage.

My good wife's health has failed somewhat, since you left us-I trust that it is only temporary; the rest are quite well. I must say, that the children are obedient, and very studious. Eliza is drawing, and devouring French Books.

I am multiplying pigeons of varions kinds ; they now amount to nearly one hundred. Our love and best respects to Mrs. Audubon, and love to John and Maria.

$$
\text { Yoür friend, J. B. }
$$

To Mrs. Bachuan :

\section{Baltimore, May 25th, 1837.}

My Dear Harriet: Although I only wrote this morning-on buard of the steamboat; yet, as I shall probably have but little time for some days to come, I write you again while I am resting from the fatigues of a very unpleasant day. I shall just go on at random, and write down any thing that may occur to me, that may, perhaps, amuse you ; trying to avoid a repetition of what I have said this morning.

In going to a new place, or to any old one, which we have almost forgotten, a thousand new thoughts come into the mind, and we are able to draw comparisons, and are furnished with facts for speculations and theories. But I did not intend to moralize, only to have a good-natured chat. $* * * *$ 
The morning after my arrival in Philadelphia I was curious to know how the old Philadelphia Market looked; I had always pronounced it to be the best in the little world that I had seen. So I rose at five o'clock in the morning, as I have invariably done since I left home, to saunter by myself and make observations. $* * *$ 'There have been alterations in the arrangement of the market houses ; they have been broken in upon by big streets, and no longer present the continuous line that they once did-as if stretching from the Delaware to the Schuylkill.

I was forcibly reminded of old scenes of twentythree years ago. There stood the identical onehorse carts, filled with churns of milk, eggs, butter, chickens and vegetalles. The old, fat, huckstering, independent, sturdy dames looking out keenly for the pennies; ready to drive a cart or a bargain-and having at all times a Roland for an Oliver-they had neither grown older, nor uglier, nor more refined. I suppose that they are the daughters of the old stock, for I did not stop to trace pedigrees. They had the same keen, careless look, and had no doubt the same minds and souls of their mothers, now gone down to the dust, and, whether it was the old or the young Rip Van Winkle, the features were so alike, that they appeared the same to me. I priced some bunches of radishes, the answer was: "A bunch for a fip, and a levy and a fip for four bunches." The markets have greatly risen in price. Fish were fine and abundant. For the first time, south of Boston, I saw several enormous Halibuts-a fish which Maria will recollect. The old fish-women had the old rudeness, slang and impudence; and very ugly words were dealt out upon rival hucksters.

I tried to remember to keep for you the bill of 
fare, placed before every little group at the dinner table of the "Marshall House." When there is a company of a couple of hundred persons, a great variety of dishes may be furnished at no material additional expense. We never had a dinner without fried frogs-I forgot to taste them-the ladies say they are great delicacies. Lobsters are abundant-in this they are before us.

The fashion of bolting down food is a striking characteristic of our nation. You sometimes cast a slur upon me for my propensities in this way; but I can assure you, nine-tenths of these gentlemen can give me a long start and beat me. I had a fancy for lobster for dinner on the steamboat, to-day, so had the lady sitting beside me, but my neighbor on the other side, as he took his seat, quietly broke off two enormous claws of a lobster near him, and laid them beside his plate, others followed suit, and when I called to the waiter to furnish us, his answer was: "There is none left;" all this while, my philosophic neighbor had enough beside him to give dyspepsia to an alligator. He seemed to go on the old principle: "Every man for himself," and even a lady's desires could not move him. There is considerable improvement in the breeding of colts and horned cattle in this country, and I am sometimes under an impression that it might be well to extend the advantages of this kind of culture to the higher animals.

I have not, as yet, had very favorable specimens of fine weather. The Spring is cold and backward, still there is a bright green and richness in vegeiation, that is peculiarly pleasant to me. Tulips are scarcely out of flower, and Hyacinths are in perfection. I confess, to my shame, I did not go to see a single garden in Philadelphia, nor once looked at the improvements in the direction of the Schuylkill; 
reserving all this for my return visit. The weather was unpleasant. Pickering and Peale will be away soon, and I spent most of my time at the Academy of Natural Sciences and the Philosophical Hall. I found Nuttall friendly-after all there is as much in the manner of men to attract interest, as there is in the spices that render food palatable. In the Philosophical Hall, I frequently took a seat in the old chair of Dr. Franklin ; I could not avoid thinking, if knowledge could be communicated in this short way, by touch or sympathy, what a world of Philosophers" Franklin's old chair would have produced!

I was invited yesterday, to meet old General Clarke, the companion of Lewis. He is now very aged and in failing health; he is on a visit to Philadelphia, accompanied by an interesting and beautiful family. I was quite pleased with him. $\mathrm{He}$ is intimately acquainted with Mr. and Mrs. Audubon, and spoke in raptures of her talents, and his beautiful taste. He seemed to retain his recollection of past events in a remarkable way. Old Dr. Kurtz and his family send kind regards. Love to your mother, to the children, and to all dear friends. J. B.

\section{To Audubon:}

Charleston, Nov. 7th, 1837.

My dear Friend: From a letter which Dr. Wilson received a few days ago, I find that you are troubled at not having received one line from me. However, by this time, your heart is at ease, as my two former letters ought, in all fairness, to have been long ago with you. Now I do not mind the frettings of old fellows like ourselves, particularly when there is a good wide ocean between us-as the storm subsides and the calm comes, they sit down and say, "Why was I offended?"

The moment your letter came to hand, I went 
down to an honest Captain, who promised to spare no pains or expense to procure the Flamingoes. I think that we shall certainly succeed; and, in good time, the Flamingoes will reach you. Sister Maria found your drawing of the Marsh-hen, sent it in a tin box thiough Mr. Berthaud, with the egg of the Flamingo.

Poor Captain Coste lost a whole barrel of birds in rum, overboard in a gale. He brought, however, safely, another containing two large White HeronsLouisiana Herons, several Terns, and Florida Cormorants, which will go by the "Nimrod," with a couple of Red-headed Vultures.

This moment, daughter Maria's letter arrived; the girls are devouring it, and I shall wait awhile patiently till my turn comes.

The Synod of my Church is about to meet. They are scouring and scrubbing and white-washing. 'They have turned me out of the Study to put it to rights; and have put my books and papers in elegant confusion.

Send me some bird-lime, I want to replace the birds intended for Earl Derby, which were.lost on the passage. If you can conveniently procure three Pheasants send them-further this deponent saith not.

$$
* *_{*} * *_{*} *
$$

Sister Maria, says she commenced a letter to you to-day, (I have my doubts), but had no time to finish it; she has been putting up curtains and other nick-nacks to accommodate some old bachelor. parsons, who will soon be with us to grace our drawing-room. Love to Mrs. Audubon, Maria and John. Good night.
* *

J. B. 


\section{To Edward Harris, Esq., Morristown, N. J.}

\section{Charleston, December 12th, 1837}

My Dear Sir: It is a long time since I have heard from or of you, and I am induced to w rite to inquire how you are, and how this uncertain world, with all its changes and chances, has used you since we met.

The Audubons I hear from frequently; they write once a week. When we shall see them again, is somewhat uncertain. I think, however, in the course of eighteen months.

The work will soon be completed, and I feel confident that it will be, on the subject of which it treats, the best in the world. When another edition of the Letter-press is published, I wish that we could persuade Audubon to correct the mistakes that were unavoidable in his previous volumes, and the book will for ages remain a monument to his industry and establish his fame.*

I have heard that you intended to visit the South again in the Spring. If so, surely you will not pass us by without a call. I shall then be quite at leisure to go with you into the country. The old range is still there and plenty of deer. I had not, for a long time, taken a gun into my hand, till a few days ago.

*In the notes to the Letter-press, Audubon cheerfully corrected the unavoidable errors.

"Ibidem. 'The birds represented in the 35th plate of my large work (Audubon's Bird's of America), I have since found to be the young of the Yellow Poll Warbler. My friend, Dr. Bachman, and myself discovered the error soon after the publication of my first volume on Ornithology.

" $I b$. Plate 55. I most willingly acknowledge the error under which I labored for many years, in believing that this species, and the Sylvia palmarum of "Bonaparte" are distinct from each other. To the sound-judgment of my friend, John Bachman I am indebted, for convincing me that the figure given by the Prince of Canino is that of our present bird at a different period of life, therefore with different plumage." 
On my return from Aiken, a friend met me at the Railroad, insisted on my spending a night with him. Nothing loth, I concluded to do so. On our way to his house we took a deer-drive. A large doe came by me like the wind, and I felt sure of killing her; but my borrowed gun snapt, and the concussion made the animal leap ; but luckily the second barrel brought her down. I thought it quite an exploit, circumstanced as I was; and this is a beginning and end of all in that line, that I have attempted for six months. Come to us, and I will give you up my old sure stands where you can kill deer, with or without a dog-gerel.

In Natural History I work by fits and starts-at long intervals, as inclination, health and duties permit. I have before me a box full of Rocky Mountain Quadrupeds. When I shall have time to describe them, I know not, but think of going to work in a day or two.

In the meantime, if you can procure for me half a dozen of your New Jersey squirrels, stuffed, you will confer a favor on me. This Genus I have found intolerably troublesome, and when I have finished it, I fear that others will have to correct my blunders. Should you be in New Jersey this Spring, you will have a fine chance of watching the warblers on their Northern passage. There are a few designated by Wilson, that we cannot find

My family all beg to be kindly remembered to you. Yours with great esteem, J. B.

The next letter tells of failing health.

To Audumon.

Charteston, - October 2d, 1837.

My dear friend-I yesterday received your very welcome letter, the first after your arrival in London, also one from John and Maria. 
I hope to be better next year, but this Summer I have suffered much from debility-have strong doubts whether I shall ever regain my strength. The least fatigue puts me in bed, and I lose my industry and energy; if I am alive, I shall take much exercise on horseback, which agrees well with me.

I have had John's old gun brushed up in fine style, I tried her at a mark several times, and am astonished at the precision with which she carries large buckshot.

I have done nothing this Summer in Natural History, but have been trying to coax back my lost health, as yet, have not succeeded, to any great extent in doing so. 


\section{CHAPTER XI.}

\section{VISIT TO EUROPE.}

ARDUOL'S DUTIES-BROKEN HEALTH-LETTER TO VESTRY ASKING LEAVE OF ABSENCE-FAREWELL SERMON-RECEPTION AT LONDON BY AUDUBON-DIAGNOSIS OF CASE BY EMINENT LONDON PHYSICIANS-JOURNEY TO SCOTLAND IN COMPANY WITH ACDUBON-JOURNAL OF EUROPEAN TRAVEL-SWITZERLANDDER BODENSEE-LAKE CONSTANCE-GERMANY - SOCIETY OF NATURALISTS AT FREYBURG-BERLIN--HUMBOLDT-PARISRETURN OF UNFAYORABLE SYMPTOMS-LONDON-VISIT TO EARL OF DERBY-ELECTED FOREIGN CORRESPONDENT OF ZOOLOGICAL SOCIETY, LONDON-LETTER FROM JOHN E. GRAY, (NATURALIST)-FAMILY LETTERS-RETURN-DOUBLE UNION BETWEEN THE FAMILIES OF BACHMAN AND AUDUBON.

CHORT excursions into the country, with daily $\int$ exercise on horseback, partially restored the health of the Pastor of "St. John's."

During the Summer and Fall of this year, (1836), Strangers' Fever became an epidemic in Charleston, and his strength was taxed to the utmost, day and night. In the Winter following, a destructive fire swept over the city, leaving many of his flock homeless and in poverty. Full of active sympathy, he exerted himself far beyond his strength, in collecting and distributing alms to the most destitute. It was said of him, "He was a father to the poor ;" "and when the ear heard him then it blessed him." But 
the spirit was stronger than the body, and when the warm days of Spring returned, the prostration of strength that had alarmed his friends the previous year, returned with double force. His Vestry insisted that, under the circumstances, it was unwise for him to cling to his work. His physicians prescribed a long sea-voyage and entire rest from labors tou arduous in his debilitated condition.

Audubon urged him to join him in London, where the best medical advice would be at hand. "Come to us," he wrote; "The sight of our happy children, Maria and John, will do you more good than all the doctor's medicine; and my old darling Lucy (his wife), is a great nurse; drive up to Oxford street, where you will find a warm welcome."

May 28th. Dr. Bachman addressed a letter to the Président and Vestry of St. John's Church :

"I deeply lament the causes which have led to this communication, but a sense of duty requires that it should not be withheld.

"You are aware of the decline of my health, and my inability to perform my clerical duties. Believing that a clergyman should withdraw from his charge whenever he ceases to be useful, I should not hesitate to send you my resignation as Pastor of the Church, were I not buoyed up by my physicians with the hope that I may yet be restored to usefulness and health. They have all, without exception, recommended a long sea-voyage. I have been informed that you are also favorable to these views. I have, therefore, after mature reflection and prayer, ventured to ask you to permit me to suspend my labors until December next." 
He suggested two plans by which his pulpit might be supplied during his absence, and closes thus:

"From my V'estry and Congregation I have experienced unceasing acts of kindness from the day of my arrival among you; and now, in the time of debility and declining health, your sympathy renders you dearer to me than ever.

"I came to you a young man; I have dwelt in your midst for more than twenty-three years. * * *

"That Being who for so many years gave me strength to perform, almost unremittingly, the duties of my calling, now has seen fit to visit me with pain and debility. In whatever manner God shall order my lot, I shall bear with me to foreign lands and through life the remembrance of a people who have aided me in gratifying my desire for knowledge, and in the promotion of benevolence and religion.

I remain, with sentiments of respect and affection, Your Pastor, John BaCHMan.

A favorable response was promptly accorded by the Vestry and Congregation. They united in urging him to hasten the preparations necessary for so long an absence from his home, and assisted him. wherever possible, in arranging for a speedy departure. As no Lutheran minister was available, many of the ministers of other Protestant denominations, with great kindness and unanimity, consented to occupy the pulpit of St. John's alternately, during the absence of the Pastor.

On the 3rd of June, 1838, he preached his farewell sermon, from 1st Thessalonians, v. Chapter, 
11th to 13th verses: "Wherefore comfort yoursclves together and edify one another, even as also ye do."

The afflicted of the congregation were very near the heart of the Pastor.

"The poor require comforters, the sick and the afflicted need consolation. Will you not perform these duties for your absent Pastor?

Of late a calamity has befallen our city, perhaps greater than any that has hitherto visited it, and many families are left without homes and in poverty, with only the sympathies and charities of the benevolent to help them. I have engaged in the work of-ministry, until arrested by disease. Alas, I can do no more! I leave the afflicted of this Congregation with you, and with the Father of the fatherless and the widow's God.

I came to you in youth, a stranger, and now for more than twenty-three years I have been intimately associated with you all. I have enjoyed a large share of your affection and friendship. Though the pleasant memories of those early days are now darkened by declining health on my part, and on yours by clouds of sorrow-afflictions which have rested heavily upon your domestic circles, and bereaved me of a multitude of my flock, yet, the place amid whose hallowed scenes I am lingering, and whose peaceful shores I am reluctant to leave, is enshrined in the sanctuary of my heart. It is connected with associations that are imperishable. It is the birth-place of the brightest of my hopes, and the scene of the most interesting of my labors.

$\mathrm{My}$ friends, I have served you long. Whether these labors have ministered to your edification and conviction, and to your comfort and refreshment, I cannot tell; nor, is it needful for me to know. I leave the result of my ministrations in the hands of 
that Spirit who searcheth all hearts, and before whose judgment-seat all secret things shall be revealed. But to-day, on this solemn, and perhaps, by the providence of God, the last occasion that I am permitted to address you. I beseech you all, by the mercies of God, young and old, rich and poor, master and servant, to close with and accept the offers of the Gospel. "Seek ye the Lord while He may be found, call ye upon Him while He is near." "Let the wicked forsake his way, and the unrighteous man his thoughts, and let him return unto the Lord, and He will have mercy upon him; and to our God, for He will abundantly pardon. * *

My friends, we have lived long together in harmony and peace, and we part in friendship and affection. Need I beseech your prayers for your absent and solitary Pastor, or your friendship for those whom circumstances command him to leave to your care.

For all past kindness, I thank you ; I would use a more expressive word, could I find it.

Conscious am I of many imperfections. Would that I had performed my duty to you better; yet, if I have neglected or injured any of you, it was not from design, and I pray your forgiveness.

I have come to you, to day, with a body weakened by disease, but with affections as warm as that of a father or a brother.

For many months to come, others will break to you the bread of life. Should any think that the step I am taking looks like a desertion of duty on my part, I would say that I have never left you, but in obedience to the calls of the Church, or in ministering to the comforts of my aged parents. I have stood by you during the desolation of Fever and Cholera. I have performed my ministerial duties even when exhausted nature admonished me 
that rest was needful. Now I partfrom you only when my ministrations would be of little service to you, and with the cherished hope that I may return to you under happier auspices, to labor with you, and, if it please God, to rest with you, at last, in your peaceful sanctuary.

Be at peace among yourselves, and may the peace of God abide upon you all.

Amen and farewell.

The long sea-voyage across the Atlantic decidedly benefited the invalid, and when the vessel reached Liverpool he stepped on shore with comparatively a firm step.

Hastening to London, he drove to the Audubons' home late in the evening. He was dismayed to find the door-knocker tied up, and the moments seemed like hours as he waited for admittance. Audubon opened the door himself, and instantly explained the door-knocker mystery-“God bless us! Welcome friend Bachman! To-day, our daughter Maria has made us grandfathers. The little Lucy and her mother are doing bravely-to bed now, old fellow, to-morrow, you shall see them."

Although benefited by the long sea-voyage, it soon became apparent to the watchful eyes of his friends, that he needed medical treatment.

Two eminent London physicians, Drs. Benjamin Phillips and Robert Carswell, were consulted. We find an elaborate opinion, several pages in length, describing Dr. Bachman's ease.

"He had been threatened," they write, "With spinal congestion, the result of chronic rheuma- 
tism. The attack of cholera and the remedies used had saved him from spinal congestion."

New scenes, and the ministry of beloved friends, in addition to medical skill and care, soon sufficiently restored the health of the invalid, to permit him to undertake, in company with Audubon, a short jour ney to Scotland.

The friends travelled leisurely through this picturesque country. They visited Edinburgh Castle, Holyrood, and other points of interest, that the wizard, Walter Scott, the friend of Audubon, has made familiar to many readers. They found stored up in the libraries and museums vast funds of information and entertainment; but Audubon wisely drew his friend away for a time, from these too fatiguing and exciting attractions, to the lovely Lake region. Here alinost as free as the birds, they lingered awhile, before presenting their letters of introduction, that would open to them noble and hospitable homes. A few weeks later, Audubon was spreading before delighted eyes his life-like, full-sized paintings of American Birds. 'The enthusiasm of the friends in Natural History, their general infor.mation and genial manners, attracted favorable attention. Many pleasant acquaintances were made, and some firm friendships formed, while in Scotland.

The intelligence of the people, the interest taken in Natural History, the admiration called forth by his first Volume of American Birds, and the facilities offered for the publication of his great work, de- 
cided Audubon to remove his residence from London to Edinburgh.

The tour through a healthful, interesting and romantic country, with such a companion, did much to restore Dr. Bachman to his wonted health of body and spirit. On his return to London, his physicians and friends confidently predicted a permanent, if not speedy, restoration to perfect health.

A large folio volume, "Journal of European Travel," carefully expanded from notes, and illustrated by roughly drawn sketches, was a memorial of his habit of close observation, and his industry in recording the same. The book would have given us interesting facts and valuable personal reminiscences in connection with this period of his life. Unhappily, during the late war between the States, this volume shared the fate of the rest of his valuable library. He had sent his books from Charleston to Columbia for safety, and when the latter city was burned, the flames did not spare his many rare volumes. Nothing remains to us of the "Journal of European Travel," but the brief pencilled sheets from which the Journal was expanded. These, however, give us glimpses into his red-letter days-days full of intellectual pleasure and profit. The animals, birds, fishes, insects and flora of the old world, were all new to him, save in books. As he visits halls of learning and eleemosynary institutions, as he listens spell-bound to grand sacred music, and as he explores the Art Galleries containing the master-pieces of the old artists, his soul is stirred within him. 


\section{Switzerland.}

Voices of strange melody reach and touch his heart, the echoes of which are to linger in his memory during his long and checkered life.

From his Pencilled Notes.

Lake Constance.

We had been winding among the hills for some hours, now ascending slowly a mountain, and then descending with locked wheels into the valleys, and now passing groves of fir and of birch, that seemed to have their roots in the shelving rocks and to cling to the sides of the mountains, when, suddenly, upon descending a hill, a lovely scene met my eye. For some moments I gazed without uttering a word. Before me lay a village with red-covered roofs and four or five spires, nestling, as it were, on the bosom of a smooth and romantic lake.

The hill-sides on my right were covered with vineyards - the vines ladened with nearly ripe clus' tering fruit. The gently rising hills on the left, were studded with white cottages, surrounded by a variety of fruit-trues. The lake extended for many miles, and mountain upon mountain rose from its bosom. The nearest to us was covered with green foliage; the more distant appeared blue, and the farthest off seemed to rise among the clouds of heaven, and were covered, as far as the eye could reach, with snow.

The passengers exclaimed, "Der Bodensee." Here then was Lake Constance, presenting a scene of grandeur and loveliness, that no lover of Nature could witness without feeling entranced. The sun is just setting as I write these notes, and the very heavens seem to be in unison with the scene. The clouds, on a blue ground, have a rich and ruddy hue, and 
the outer edges are wreathed with silver. The houses situated on the very banks, cast their images on the almost unbroken mirror before me. The only bird that is flitting over the lake is the European "Stormy Petrel." The representative of a storm seems out of place on this lovely, placid lake.

I looked behind me; how different the scene! Dark and murky clouds are hanging over the snowclad Alps, and the setting sun renders the wintry scene more desolate. Fogs from the thawing of the ice arise from the valleys, and the rugged rocks seem to extend their arms to protect the stunted plants that are growing in their crevices. Now, as we enter - the little harbor of Constance, the sun is casting his last shadows on the lake. The boat is moving slowly. The sun seems to set almost behind the waters, rising and sinking at the moment of his departure, and leaving a golden stream on the edges of the neighboring cloud, reminding me of the last hours of a just man's life-calmly, as the setting sun, his day closes, and the bright light of his example is left to edify and to gladden the world. For half an hour after sunset, the golden hue lingered on the waters. It softened and faded, and ray after ray so imperceptibly left the unruffled wave, that my meditations were only broken off by the landing of the boat, which reminded me that darkness had set in.

Freyburg, September 18th: Presented myself yesterday afternoon before the Zoölogical Department of the Society of Naturalists, at Freyburg.

A great crowd hastening to this meeting thronged the doors. The members with some difficulty effected an entrance.

The applicant for membership must prove that he has published something in Natural History.

My German friends had preceded me and notifiert 
the Society of my intended visit, and I was received with great kindness,

The largest hall in Freyburg had been elegantly decorated for the occasion. Five hundred members were present.

The ladies were accommodated in the gallery, and the other visitors had a place assigned them on the ground-floor. It was a very orderly meeting.

First, a long report was read by the Secretary in German, followed by a lengthy Eulogy on a deceased Officer of the Society. Then several Essays were read, viz: "The Structure of the Earth;" "Water" Falls;" with illustrations, etc. I was most pleased with one from Professor Martin, of Munich, on "The American Indian," intending to prove that the mounds, and especially the traces of fortifications and architecture found in Mexico and South America, gave evidence that they were the work of a different people and a former age. It was a sensible production and remarkably well delivered.

A band of music from Berne, consisting of forty musicians, played during the dinner, which lasted from one P. M., to four in the afternoon. The dinner was excellent-the best that the country could afford; but it lasted entirely too long for me. Toasts were drunk, first to the Grand Duke, and then to the German Naturalists. A short speech evidently, prepared before hand, preceded the toast, at the close of which all rose, and the "Lebe hoch" (long live) was repeated three times, with great enthusiasm.

The dinner, including wine, cost each member the small sum of seventy-five cents-a vast difference on similar occasions, in England and America. After dinner, the Naturalists took a recess of an hour or two. Repairing to a mountain on the borders of the city, we ascended, by tortuous windings, till we 
gained the summit. The scene was picturesque, as group after group-to the number of a thousand, were seen winding their way around the mountain. All appeared to be gay and happy.

On the eve of his departure from Freyburg, Dr. Bachman sent a communication to this Society, a fragment of which has been preserved. It reads thus:

In the course of a tour through Europe for the benefit of health, I was so fortunate, as unexpectedly to have been with you at your interesting anniversary meeting.

In compliance with the wishes of the members of your Society, and with the desire to draw the Naturalists of both countries into a closer bond of union, I consented to lay before your Association an account of the progress, and the present state of Natural Sciences in the United States. I intended to make only a verbal statement, as well as I was able, in your own language. I find now that my limited time compels me, before the next meeting of your Society, reluctantly to leave this delightful retreat of men of science of Germany and Europe.

Permit me to express to you the profound emotions of pleasure, with which I witnessed, for the first, and probably, the last time in my life, so large a meeting of eminent men, who were laboriously engaged in the cause of science. I felt it a privilege, even for a day, to sit down with those who were investigating the wonderful works of nature's God. How delightful to me was the change, from the perils and solitude of a long sea voyage, to your romantic hills and beautiful Himmelrich.

In a letter from his friend, John G. Morris, D. D., dated a few months later, we find the following: 
"I received your letter per Great Western, and thought that you would not object to an insertion of a part of your letter in The Lutheran Observer, without your signature.

I have been asked several times who at the Naturalists Reunion was the one poor representative from the United States?

"One of the City papers (Baltimore), says in a short notice of that meeting, "The United States," were represented by the Rev. Dr. Bachman, of Charleston, S. C., the first Ornithologist in this country."

$$
\text { J. G. M. }
$$

The land of Luther had its special attractions for the Pastor of St. John's. He regarded each scene connected with the successful labors and conflicts of the Chief Reformer, with keen and almost sacred interest, and the healthful life of its people, in communion with Nature, was congenial to his simple taste.

Arriving at Berlin, he found a great pleasure awaiting him, for Humboldt was there. Dr. Bachman tells us, "I was a youth of sixteen, when Humboldt visited America. Wilson, the Ornithologist, procured for me an invitation to be present at a reception given in Philadelphia to this eminent philosopher and naturalist. During my stay there, I saw him every day. Before leaving, he inserted in his note-book the names of his acquaintances in Philadelphia, and, to my surprise, mine was included on the list." 
In 1838, Dr. Bachman gratefully records, " Humboldt was the first to receive me in Berliv, and to extend to me civilities that made me feel at home among the men of science in the Father-land."

In 1869, thirty-one years later, at the request of his German fellow-citizens, in Charleston, he delivered the address commemorating "The Centennial Anniversary of the birth of Humboldt."

Reluctantly he left Germany for France. While in Paris all his unfavorable symptoms returned; the French physicians called in, took a less hopeful, and less correct, diagnosis of his disease, than that given by the English practitioners. Hastening to London, he placed himself again under the care of his former physicians, Drs. Phillips and Carswell, and slowly recuperated. Happily, congenial recreation and pleasurable excitement were abundantly provided for him. He had letters of introduction to the venerable Earl of Derby (grandfather of the present Earl). The Earl was an enthusiast in the study of Natural History, and greatly interested in America, as a new field opened for investigation. He had invited Dr. Bachman, on his return to England, to visit him at his beautiful country-seat.

As soon as strength permitted, he gladly availed himself of the privilege actorded him, and spent days examining the Earl's large collection of animals and birds, both living and stuffed. As he roamed through extensive, highly cultivated gardens, and leisurely studied the Flora of many lands, his step became more elastic, and a healthier glow began to 
tinge his cheeks. At parting, the Earl presented him with several rare books.

While in London he received the thanks of the '/oölogical Society for the present of thirty-six skins, (eighteen Mammalia and eighteen birds), from North America, which were deposited in the British Museum. At a General Meeting of the Society, held on the 6th of December, writes the Secretary, John Barlow: "You were balloted for and elected as a Foreign Correspondent of the Zoölogical Society of London."

\section{From John Edward Gray,}

\section{The Eminent Naturalist in Charge of the British}

\section{Museum.}

\section{British Museum, Nov. 1st, 1838.}

My Dear Sir: I have sent you the Volume promised. I hope that it may interest you, and furnish you with a little information respecting the Continental Collection. Hoping soon to see more of your labors-as it is to you, that I look for a good account of the American Mammalia. I expect soon to print my synopsis of Mammalia, and will send you it directly it appears, but I consider it my duty first to attend to the wants of the Collection under my charge, so it may be delayed sometime. Wishing you a very pleasant voyage.

* * * *

J. E. GraY.

We trace the movements of Dr. Bachman through the following letter written by his daughter Eliza (afterwards Mrs. Victor Audubon), to her younger 
sister, Harriet Eva, who was then on a visit at a plantation, near Charleston.

December 11th, 1838.

"Do not think, my dear sister, from my long silence, that I did not appreciate your irelcome letter. I am in debt to all my correspondents; and, when I tell you that my dear Ria, (sister Maria), is included among the number, you may console yourself. The truth is, I have been busy and felt unsettled. The drawing and dining rooms, have, been newly painted, so we have occupied the painting room, as it has long been called. Although the appearance of the room is now changed, yet, I am constantly reminded of the time when the Audubons were here, and when I spent so many happy days with our dear Ria. I look at the seats, once so agreeably filled, with a feeling of regret that those who occupied them are so far away from us.

A letter has just been received from Ria, written in excellent spirits; but, alas! she gives us little hope that we shall soon see her. Mr. Audubon's letter-presis, has occupied him a much longer time than he expected, on account of the number of new birds which have been discovered, and he now fears that those delightful episodes, which seemed to give universal pleasure, will have to be omitted from want of space.

Ria writes that the little Lucy already weighs seventeen pounds; she will soon, at that rate, be a weight to carry.

The Audubons are delighted with Edinburgh. If the city equals the descriptions I have so often read, it must, both in point of natural scenery and agreeable society, be far superior to the far-famed London, with all its bustle and humbug. The latter' 
may better suit the rich and the gay, but for those whose circumstances are moderate, and whose pleasures are rational, Edinburgh must be far preferable as a place of residence. The Audubons' house is delightfully located and exceedingly convenient.

We are now looking, with the greatest anxiety, for the arrival of father; the last few weeks have seemed like so many months. Is it not astonishing how slowly time creeps on, when we have pleasure in prospect.

Although the last accounts from our dear father, are not very encouraging, yet our hope is, that on his return to us, the rest and the quiet of home, may do much toward restoring him to perfect health. My earnest prayer is, that he may regain his wonted strength and activity, and long be spared to us; for we have learned from sad experience, how essential his presence is to our happiness.

Thursday 12th: We received letters from father to-day, which give more encouragement with regard to his health. He was to sail in the "America," which is daily expecter

* * * $*$ M. E. B.

After an absence of eight months from America, Dr. Bachman reached home January, 1839.

The joy of family and flock, at his return, was not without alloy. They were disappointed to find his health still very feeble. The congregation proposed that an assistant should be secured. At the recommendation of the Rev. Dr. Mayer, the Rev. William N. Smith was engaged by the congregation of St. John's as assistant minister; and for several years, he rendered acceptable service. 
During the year 1839, Victor G. Audubon, the eldest son of Audubon, arrived in America, visited Charleston, and spent months in Dr. Bachman's home. Before the close of his visit, he became engaged to Mary Eliza, Dr. Bachman's second daughter.

Friends who had watched from childhood, the strong and ever increasing bond of affection between the sisters, rejoiced that they were to live again under the same roof. A letter from Aububon expressed his great pleasure at this second union between the families. Bachman's reply was characteristic.

Your congratulations at this double union in our families are right and proper, nor ought I to be so selfish as to wish to retain my children around me when their happiness requires a removal; but somehow, the event which causes you so much pleasure, has a contrary effect on me. I am a Philosopher in most things, but in this case Nature is too strong for Philosophy. 'The girls have good husbands, who, I am sure, will take care of them; but to me the parting with them I feel to be a very great loss; but I will try not to complain about it, unless others wish me a joy which I do not feel, and which I would be a hypocrite to acknowledge.

I was glad that I was compelled to be absent when Eliza left me, and was obliged to preach in the country twice a day for a fortnight, and had thus incessant occupation, without too much time for thought. When I came home, however, the holidays had scattered the rest of my little flock. It was so lonely, it almost gave me another attack of dyspepsia. But let us talk of other matters-of your 
synopsis for the "Small Edition of the Birds." The size and the plates, etc., please me very much. Your synopsis is the best I have seen, though that is not saying very much, for the majority I think bad. I am glad that you have given us this, it will save you much trouble, and your readers much perplexity. $* * * * * * * * *$ By the time four or five numbers are published, you may turn over the work to your sons; but, till then, you should carefully review every page and plate. The next thing, will be to get subscribers. This would be purgatory to me; but it is necessary for success. While Arumming up subscribers, you may obtain specimens for the Quadrupeds. These creatures-the majority of them nocturnal, and living in concealment-are not so easily obtained as birds; but there are fewer of them, every species is abundant in some locality, and they neither migrate nor fly. You cannot do without me when you come to the animals I know full well-so you will have to come and pay me a visit soon. ****

Love to my daughters and sons, **** J. B.

The following girlish letter is from Harriet Eva to her newly married sister, Eliza (Mrs. Victor Audubon):

Charleston, February, 1838.

I have just returned from a visit to the country. Last year when I came home, you were the first to greet me. I cannot realize that you have indeed left us. You don't know how we all miss you. Father, mother, and all, are continually sounding your praise. * * * * * *

We are sorry to hear that our dear Ria has suffered so much. She has not written to us since Christmas. I often wish that I could take a peep 
at you and our dear Ria, as you talk over the old times. I want to see little Lucy. Susan R. R. sends her love. I heard her say to her aunt, Mrs. R., that you played on the guitar and sang delightfully; and that Ria, with all her accomplishments, knitted father's socks. T'ell Ria the shawl she knitted for me has been greatly admired. Write soon, we are all anxious to hear from you.

Your loving sister,

HARRIET.

To Auduron :

Charleston, September 13th, 1839.

"I congratulate you all on your safe arrival, in spite of storms, calms, and hurricane. But after this, don't speak of the tardy progress of Charleston Packets. I beat you both ways, and had pleasant passages withal. The voyage from England to America, along the Northern coast, is seldom as pleasant, and never much shorter than the Southern course, especially in winter. We sailed to Latitude $20^{\circ}$, and then took the trade winds, and it reminded me of sailing on a mill pond-so smooth was the water.

I am sorry to hear that you have not been quite well; as we get to be old boys, aches and pains will come. Let us both agree not to complain. My

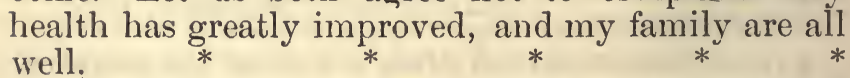

I am glad that you are about to do something with regard to the "Small Edition of Birds." But are you not a little fast in issuing your prospectus of The Birds and Quadrupeds, without having numbers of both works, by which the public can judge of their merits? My idea, in regard to the latter, is that you should carefully get up, in your best style, a volume about the size of "Holbrook's Reptiles." 
This would enable you to decide on the terms of the book. I think that two thousand subscribers at $\$ 1.00$ for each number, might be obtained. But it must be no half-way affair.

The animals have never been carefully described, and you will find difficulties at every step. Books cannot aid you much. Long journeys will have to be undertaken. Several species remain to be added, and their habits ascertained. The drawings you can easily make, if you can procure the specimens. I wish I had you here, if for only two days. I think that I have studied the subject more than you have. You will be bothered with the Wolves and the Foxes, to begin with. I have two new species of Bats and Shrews to add. The Western Deer are no joke; and the ever-varying Squirrels seem sent by Satan himself, to puzzle the Naturalists.

*

* *

Iove to all. It will be a terrible disappointment to us, if Maria, John and the little Lucy do not come to Charleston this winter.

J. B.

\section{January 13th, 1840.}

"I think that your "Birds of America," will be a standard work for centuries; ere then, we will be among the planets studying something else. The descriptions in the "Small Edition of Birds," will have to be abridged-your "worthy friend" and other humbugs may be left out to advantage. I am not at all surprised at your success in getting subscribers; but let me say, cities are not the only places to obtain them. Birds sing and nestle among the groves of the country-The planters and farmers are the men to become subscribers. An intelligent planter from the up country said, a tew days ago, that if the right person would thoroughly canvass the whole State of South Carolina, he would 
insure three hundred subscribers to the "Small Work." Old Jostle would be the man, and when his legs failed, the Young Jostle should go forward.

Get the Editors to notice your work-this is a puffing world-from the porpoise to the steamboat.

When we meet, we shall talk about the partnership in the quadrupeds. I am willing to have my name stand with yours, if it will help the sale of the book. The expenses and the profits shall be yours or the boys. I am anxious to do something for the benefit of Victor and John, in addition to the treasures I have given them-and this is all I can do.

Love to Maria. Bring her to us before the Spring. This lovely climate is a cure for sore mouths or sore hearts. Tell dear Eliza, her boy William is studying a Latin Grammar, and perhaps may one day be able to write his thoughts to her in Latin-for his penna, penno, are dinging in my ears morning and night. He is a good boy.

Employ yourself now in drawing every quadruped you can lay your hands upon. If you can find me a live Ermine, buy it in New York. I must once more examine and study its change of pilage.

Don't flatter yourself that the quadrupeds will be child's play. I have studied them all my life. We have much, both in Europe and America, to learn on this subject. The skulls and the teeth must be studied, and color is as variable as the wind; down, down in the earth they grovel, while we, in digging and studying, may grow old and cross. Our work must be thorough. I would as soon stick my name to a forged Bank Note as to a mess of Soupmaigre."

Your friend, 


\section{CHAPTER XII.}

\section{Passing Under the Rod.}

FAMILY LETTERS-MRS. JACOB MARTIN-DEATH OF HIS DAUGITERS-TIIE SECRET OF LARGE SYMPATHY.

$E^{X T R A C T}$ from a letter written by Rev. John B. Haskell, at White Hall, S. C, while arranging his grandfather's letters for Biography.

To C. L. B.

"You have no idea what a mass of letters I have collected. I am happy in my work wandering in days that lived ere I was born, and drinking in the pure spirit of my noble grandfather.

"In prayerful thought my heart turns to the old roof-tree, under which so many of our blood have shed their tears, exchanged their smiles, and walked in paths of duty and love. Feet so still and quietresting now; but which, one day, will leap up in the perpetual youth and strength of eternal life, to walk in the streets by the River of Life, and to dwell forever in the City of Gold."

Extracts from some of the letters alluded to, will be found in the chapters that follow.

In 1839, Dr. Bachman's fears were thoroughly aroused with regard to the failing health of his oldest daughter, Mrs. John Audubon. The Audu- 
bons had returned from Scotland, and were living in New York. In his letters to his son-in-law, he deprecated a Northern winter for the invalid, and urges her husband to bring her South.

January, 1840, they arrived in Charleston. The household treasure, the father's companion, and the mother's right hand, was restored for a season to the home of her childhood.

Beloved friends welcomed the invalid, and skilled physicians watched over her. Her husband " hoped against hope;" but the practised eye of her father, could not be deceived.

A G.erman author has said, "Every man in the course of his life is called upon to offer up to God his Isaac." This call had now come to the Pastor of St. John's.

T'To Victor G. Audubon:

Charleston, May 10th, 1840.

My Dear Victor: "I am very sorry that I have nothing favorable to write you with regard to Maria.

I was at her bedside a few moments ago; her pulse is feebler.

*

$*$

*

We have had many heavy trials of late, but none equal to this. I have had philosophy, and, I trust, religion, to stay me under all other calamities; but here I stand unhappy and bewildered. I trust that dear Eliza will be strengthened to bear up under this visitation. We must look upwards to the Higher Power-to God for support; all is under the direction of His wisdom. Maria's health had seemed to me for months on the decline. When the physicians advised a change to Aiken, we took her there and cherished a hope that pure air might 
benefit her. Yet John's favorable reports did not satisfy me; for he has, all along, seemed almost blind to her true condition. I went up to see for myself; the first glance told me that she was much worse. John is not only devoted, but he is the best nurse I have ever known. In Aiken she was with the kindest of friends; but she longed to be at home, and we have brought her back.

Tell Eliza to summon all her fortitude and her trust in God. Concealment of facts leads frequently to deeper and more poignant sorrow than if the whole truth had been, at once, revealed. Maria's physicians encourage no hope-and we are but hoping against hope.

Need I remind her husband, parents and sisters, that in the event that will cloud our prospects with deep gloom and bitter sorrows, there are yet consolations. Think of a future state. Remember her obedience, kindness, goodness. and above all, her faithfulness in serving her God.

I accompanied your father yesterday to the funeral of our friend, Dr. Rham. How melancholy! I pity his absent family with my whole heart.

How much I regret that the situation of my own family on his arrival was such, that it was impossible for me to take him to my home, as I had intended.

Mrs. Martin is not expected to survive beyond a day. We are all greatly fatigued; but are better in health than could be expected, under present painful circumstances. Affectionately, your father,

(Enclosed in the same.) J. B. Audubon to his son Victor.

My Dear Victor: John Bachman has told all that can be said with regard to our beloved Maria's 
condition. I can assure you, as he does himself, that this last week has been one of deepest sorrow. I go to the city-anywhere, I scarcely seem to see or to care for any one-and the return home only augments the pains of my poor heart. * * * * *

Alas! who can foresee or foretell! In a few days, my fears tell me that we shall have to convey to you sad tidings; yet I still hope that God may spare our Maria.

God bless you all. Take care of Mama, of Eliza and the babe (Harriet); little Lucy is well.

Affectionately, your father,

$$
\text { J. J. A. }
$$

Mrs. Jacob Martin (Mrs. Bachman's mother) had been for years an honored inmate of her son-in-law's home. Possessing a singularly rounded character, as firm as she was gentle, thoughtful, yet not overcareful, her presence exercised a wholesome influence in her daughter's family. In fact, the Pastor of St. John's rejoiced that the children's grandmothers should both dwell under his roof. It was good for the children, from infancy, to learn the joy of service to those who had not too many joys left on earth. The Pastor's own reverent bearing to the aged mothers, was naturally adopted by the young niem. bers of his family; and who can estimate the blessings that flowed into the current of these young lives, through even the silent teachings of these dear, aged saints. The unquestioning submission of such as these, is both a prayer for and a benediction upon a household. His own mother had finished her long prilgrimage, and had already entered "the life where 
death is not," and to-day, Mrs. Martin is passing through "the valley and the shadow of death."

A few days later, the mourners laid her venerable form to rest in the cemetery of St. John's-to await the resurrection morn.

Mrs. Audubon, by the advice of her attendant physicians, was not informed of the death of her aged relative. She lingered on through the hot months of July and August. Very gently, in love, the cords that bound together the dying and the living were unloosed; the Angel of Suffering, did his part in preparing all for the parting hour.

One day in Sentember, the sufferer exclaimed, with a far-off look in her eyes, "I see Grandmother; she is in heaven." The soul of the dying may have caught a glimpse of the other shore. Then with uplifted eyes, she slowly repeated:

"Vital spark of heavenly flame,

Quit, $O$ quit, this mortal frame;

The world recedes ; it disappears.

Heav'n opens on my eyes; my ears

With sounds seraphic ring,

Lend, lend your wings ; I mount, I fly :

$\mathrm{O}$, grave where is thy victory?

$\mathrm{O}$, death where is thy sting?

A few days later, and the lips that had praised her Maker from childhood, were silent in death. The record is, Maria R. Audubon, beloved daughter of Jolin Bachman, and wife of John W. Audubon, died September 23rd, 1840, aged 23.

The Pastor of St. John's entered into his study, and closed the door, even to his nearest and dearest, 
saying, "Give me one day for the luxury of grief." Then he came forth, and calmly took up the duties of life.

The following November, the South Carolina Synod convened at St. Paul's Church, Newberry. Dr. Bachman was the Presiding Officer. The text he selected for his sermon is suggestive-1 Samuel iv. 13. "And when he came, lo! Eli sat upon a seat watching; for his heart trembled for the Ark of God." The supporting power of grace was lifting up God's servant above personal sorrows. The safety and prosperity of the Church, not his own griefs, were pressing upon his heart.

In the day of bereavement the tender hearted Professor of theology, Dr. Ernest Hazelius-a brother born for adversity, stood at his side.

Many others, according to their own fashion, sought to cheer him, and his heart did not refuse to be comforted.

A great calm had entered into the soul of the Pastor of St. John's ; God was preparing him to pass again, "under the rod."

In October, Mr. John Audubon and his little daughter, Lucy, accompanied by Miss Martin, sailed for New York. They found Mrs. Victor Audubon already sadly changed. Perhaps the shock of the unexpected separation from her idolized sister-the nine months of anxiety, and, at last, the end of all earthly hope, may have caused her illness.

It was immediately concluded that her husband, and Miss Martin should without delay take the 
invalid to Cuba. It was not thought advisable to select the route via Charleston; there were too many recent sad memories in the early home; she was to stop there on her return.

Her father wrote to Mr. Victor Audubon:

\section{Charleston, October 27th, 1840.}

Dear Victor-By your letter, you were to sail on Wednesday last; if so, by our calculations, you must now be somewhere off Charleston or Savannah. There have been fair days, and I hope that you are all free from sea-sickness. I found, in the latitude of the Bahamas, Summer weather in December.

We are, of course, not free from anxiety; but we all hope and pray for the best. A ship-voyage may be beneficial to Eliza. I have all confidence that this, together with travelling and visiting milder regions, will materially improve her health. * *

On the same day he wrote to his daughter.

My dear Eliza: We received your few lines, and all feel truly anxious for your recovery, and return to us in good health. I was at your age, much worse than you are. I had broken a blood vessel, was confined six months to my bed, and was given over by Dr. Rush, and physic. A voyage to Jamaica and a subsequent residence in Charleston, affected a cure-without medicine. Be cheerful and content. Look, as I always try to do, on the bright side of the picture. Keep a good conscience ; trust in your God, and all will be well.

Your affectionate father, 
From Audubon, to his Daughter-in-Law, Mrs. Victor Audubon.

\section{Minnie's Land, New York, (1840.)}

My sweet child: I am sorry indeed, that you have not felt willing or equal to write us more than you have done.

I trust that the weakness you suffered from is passing away. You cannot well conceive how anxious we are to have you again under our own comfortable roof. Although you are in a delicious climate, yet, "Home, sweet Home," is best for the invalid.

May God direct all your prescriptions and medicines. May $\mathrm{He}$ grant you all assistance, take away all fears, and return you to us as happy, bright and blooming, as when it was my delight to call you, " my beloved Rosy."

Love to Victor and to my friend, Maria Martin. Your affectionate fathér, J. J. A.

Judge Dunkin, (afterwards Chief Justice), wrote to Dr. Bachman from his plantation at Waccamaw, near Georgetown, S. C., "Pay us a visit, bring your daughter Jane with you and leave her with us; she needs a change of air and of scene." They accepted the invitation.

On his return to Charleston, he wrote to his daughter Jane, at Waccamaw.

Charleston, December 26th, 1840.

"I hoped, my child, to have wished you a "Happy Christmas" on the very day, but I did not come home between the two services, so have lost the mail. 
This is Saturday, and you know I shall be very busy. I begun this letter by candle-light, having been called up during the night to baptize a sick child, I therefore, wile away the early morning hour in writing to you.

Mr. C - met Eliza and party in New Orleans; from his account, she is, at least, no worse. By this time, she must be in Cuba. I wrote to her last night, by a vessel that sailed for that port.

When I reached Georgetown, the steamboat had not arrived. I waited until 4 o'clock P. M., and thought it best then to take the stage. It was the little apple cart I came up in. The seams below were open, and the winds had a fair sweep through the little vehicle. It was a sadly cold night. You know, however, I profess to be a philosopher, and I made the best of it. I had occupation and amusement, for the stage door flew open about every quarter of an hour, with a considerable degree of regularity, and, by counting the number of times I shut the door, $I$ could make a tolerable guess at the distance travelled. The stars were bright, and I could easily see them through the torn curtains; and I brushed up the little Astronomy that I had not forgotten. At "Santee Ferry." I had the coach filled up with straw, and there I met $\mathrm{F}_{*}$, and was glad to have company.

Thank our friends for all their kindness. They have given me pleasant reminiscences of Waccamaw turkey, Waccamaw snipe, and good long Waccamaw yarns. I have come back to my duties with better health and redoubled relish."

To John W Audubon.

January, 1841.

My health is, on the whole, good; but the least over mental exertion, or a neglect to spend a day in 
the week out of the city, and I find my digestion affected. Strange that with little practice with the gun, I should shoot more steadily than formerly. I recently had three long shots at deer-killed two and wounded the third. I never saw such quantities of ducks as at Waccamaw. I killed seven English ducks with one barrel. and five with the other. On the morning before I left, I took them singly, I had fourteen shots at English ducks, and killed every one. I had many spectators, and a kicking gun, from which my cheek suffered. If John had been there, with his big "Buffalo," (gun) he would have astonished the ducks. I have an episode to add; They are ready to swear at Waccamaw, that there is a new species of English duck, common there in March-smaller than ours. They will send some down to me, and we shall see. I received yesterday, a Black-winged Hawk-killed at Edisto ; take notice, in Winter. Query-have they ever been seen so far North as this, in Summer?

P. S. I have just heard from Victor; he writes, "Eliza is a little better." Out of the seven letters sent by us to Cuba, not one has yet been received.

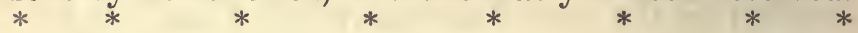
J. B.

From Mrs. Victor Audubon :

Havana, Cuba, March 14th, 1811.

" Dear J.'s letter was the first received, since our stay on the Island, and it gave us great pleasure. I have been prevented by indisposition, from answering it. To-day, I feel unusually well, and so write to you all whom I long to see. Do not fear that my kind husband will take me North, without my seeing you all, in my first happy home. The thought of meeting my beloved family and friends in Charleston, has filled my mind both night and day. 
For months, all my leisure time has been spent in fancy work, that I might have something for each of my friends. Tell Dr. Holbrook that I have everywhere enquired for shells, and have obtained quite a nice collection for him. The only shells that I found myself, were among the rocks and the stones at "San Pedro"-scorpions live there, so I was in danger of being stung all the time. The people here, seem to have no taste for Natural History, and pass by the greatest curiosities without noticing them. Mr. B. is the only exception we have met with, and our visit to his delightful family, is like a green spot in the desert. We left San Pedro, yesterday. All suffered from sea-sickness, except myself. I was able to sleep for the greater part of the day, and found on our arrival at the hotel in Havana, that I was well enough to help to take care of the sick. Do not think that when we meet, you will find no traces of disease in me; every breath I draw, convinces me that there is something to be removed, before health can return. Yet, when I see invalids in the last stage of disease come flocking to this Island, I feel grateful that loving friends have removed me in time, that my life may be prolonged-perhaps for years.

My mind is dwelling upon the thought, that I shall take Jennie back with me to the North. It was dear mother that first gave me the promise, tell her to remember that I cannot bear a disappointment; nothing will add more to my improvement than to have her with me-the walks and the drives we shall take together, will serve to amuse and strengthen me. You will see us in a few weeks. M. E. A.

Letters to the little brother and sister were en. closed. 
Dr. Bachman, in a letter to Audubon, writes:

"Eliza has written to us; she feels herself a little improved; but, from her account, there seems to me no change for the better. I am glad to hear that. our little Lucy and Harriet are well and happy. We are not all well, for my wife's health is impaired; she has neuralgia in an aggravated form, and her constant anxiety about Eliza prevents her from improving.

Thanks for the dog. It arrived in fine order, and promises to be a good hound. Dr. Desel has shown such hospitality to us all, that I sent the fine animal as a present to him, in John's name. He was as fat as a seal, active and playful. He has written a letter of thanks, and sends you all a warm invitation to come to "Liberty Hall." I wish, indeed, that you were here now, to take a little recreation with me. You shall have a further report of the hound, when he knows a deer from a rabbit.

Amid April showers, the travellers returned from Cuba to Charleston. All strove to be cheerful. The flowers were blooming and the birds singing. Audubon's "beloved Rosy" from childhood was the life of the home. Maria had been less gay - a gentle gravity, a singular devotion to duty, had characterized her. Eliza was the family poetess and songstress, the promoter of innocent mirth-ever assured that her small efforts would please and amuse. Now, she strove to cheer her mother; she did not dwell on her own pain or grief. She suffered chiefly from debility; daily fevers were sapping her young. strength. 
Dr. Bachman wrote to the Audubons:

May 8th, 1811.

"Victor, Eliza and Jane have just sailed (10 A.M.) for New York, in the ship "Calhoun." Eliza has not improved. Drs. Geddings and Horlbeck pronounce the case hopeless.

We have yielded to a sad and bitter necessity in parting from her, under these circumstances. Mrs. $B$. has had a return of ticdoloreux, and is confined to bed."

Mr. Victor Audubon and his family, under the impression that the tender and sorrowful memories lingering around her home, would retard the recovery of the invalid, and still clinging to the hope that her health might be restored, urged her return to their lovely rural home on the Hudson.

To his Daughter Jane:

\section{Charleston, May 11th, 1841.}

"It is three days since you left us. We have been watching the winds and the weather, and if good wishes and prayers avail, you will have a short and pleasant passage. On Sunday it blew almost a gale here, with a head-wind; yesterday and to-day, the winds are fair. I think you must have passed "Cape Hatteras;" if so, this letter will meet you in New York. I need not say, that we are all anxiety until we hear from you. Your mother rests pretty well; but her pains come on at day-light, and sometimes last all day.

The children are well and at school. W. is up at day-light looking out for fair winds, and asking many questions about the time we may hope to hear from you. 
Dear Jane, you will have an anxious and sorrowful time; but these sorrows, cares and duties, will discipline you for the future, and render you more useful, and better prepared for both worlds.

We have parted from you with great regret; and nothing but a sense of duty would have reconciled us to your leaving your poor mother-we shall miss you every hour-and no one more than your mother. Under all circumstances, try to do your duty. Your affections will prompt you to do all that lies in your power to relieve and console your suffering sister; and you must direct her to place her trust on Him, from whom all our alleviations and blessings flow. Write what you think of Eliza's case-neither flatter nor despair. The plain truth, without concealment, is the safest and best in the end. Walk out every day, when you can be spared; try to preserve your health and strength, your industry and energy, for future trials, should God see fit to send them ; and for many years of happiness, which your dutiful conduct so well deserves.

Your mother and every member of the family join in affectionate remembrance tr you and to all, and especially to our dear Eliza." *** J. B.

Two weeks later, Mary Eliza, second daughter of John Bachman, and wife of Victor G. Audubon, died at the age twenty-two. She was laid to rest in the Cemetery at "Audubon Park," New York. A Lutheran clergyman, Rev. Mr. Martin, performed the last sad rites.

\section{Dr. Bachman to his Daughter Jank.}

"Victor's letter announcing the additional weight of sorrow and affliction that has befallen our family, was received to-day. Though in a manner prepared 
for it, from what we had seen of her wasted strength, we did not expect it so soon. The ways of God are dark and incomprehensible to us poor short-sighted mortals. It, is our duty not to murmur, but to pray for submission. When Providence, in early life, removes from us those who have trusted in God, and faithfully performed their duties, we should believe that they have accomplished the work their Maker designed them to perform, and have lived a long life in a few years. In indulging a natural sorrow for the departed, let us not forget our duty to the living.

You have had a severe trial-you have witnessed her last hours. I pray God to soothe your griefs, and strengthen you for the duties now before you.

You are aware how deep was our regret at parting from you. Now, since vour melancholy duties are performed, we long for your immediate return. You have always been a comfort to your parents, and especially to your mother, who now needs you more than I do. How far this new trial will affect her, I know not. I trust that, on your return, you will find her better than when you left her, and as composed in mind, as can be expected, under present circumstances.

Victor and John will make all necessary arrangements for your return-let it be immediate. Now that the hand of God is upon us, we look not only for His support, but also for the stay, the sympathy, and presence of our friends.

\section{DEAR VICTOR:}

I do not know that I can add anything that will tend to alleviate your sorrows and comfort you under an affliction that has fallen on you, in common with us. You have our deepest sympathies. We pray God to support you.

Your affectionate father, J. B. 
Again he closed the door of his study, and wrestled with the Angel of the Covenant. It was not for himself alone that he entered into thick darkness, or for himself alone that he came out into the light. Duty has been called "The stern daughter of the voice of God." Yet as she leads forth a bleeding heart to minister to suffering humanity, is she not transformed into an angel, with healing on her wings? Men spoke of the "large sympathy" of the Pastor of St. John's. Was it not God-given, in the furnace of affliction? 


\section{CHAPTER XIII.}

Lights and Shadows.

DEGREE OF DOCTOR OF PHILOSOPHY CONFERRED-ELECTED TO VARIOUS SCIENTIFIC AND LITERARY SOCIETIES IN EUROPE AND AMERICA-ST. JOHN'S CHURCH COLONIZES-ILETTERS TO AUDUBON ON HIS RETURN FROM ROCKY MOUNTAINS-QUADRUPEDS OF NORTH AMERICA-VISIT TO AUDUBON-HIS DAUGHTER JULIA-JOY AT THE BIRTH OF HIS FIRST GRANDSONFAMILY LETTERS.

To Audubon :

Chakdeston, August, 1842.

"My Dear Friend: I have just returned from a visit to the country, where I have left Mrs. Bachman for the benefit of her health. I have a season ticket on the railroad, and, on my weekly visits, I do much of my writing on Natural History. The moment the clock strikes four I am up, and soon at work. From this hour until seven, I have no interruptions. I hope in this way to steal time to write about Quadrupeds. When I get fairly under way, as I am now, I am not very easily diverted from the object before me, and nothing but ill health or domestic affliction will keep me back."

J. B. .

His love for Nature in all her forms made these days of recreation fruitful to others, as well as healthgiving to himself. Wherever he went, his pupils 
and assistants brought to him the results of their investigations, which he faithfully recorded in his little note-book. Teacher and pupil became alike enthusiastic over their discoveries; but the good work did not end there. Under the broad canopy of heaven, timid souls almost unconsciously laid bare to him their hearts, and drew from him wise counsel or tender sympathy. It has been said of him, "Hissimple, child-like character inspired confidence, almost instantaneously."

Dr. Bachman, from 1835, besides writing numbers of miscellaneous essays and reviews for scientific journals, contributed largely to the Editorial columns of the Southern Agriculturist. His labors introduced him to The World of Science, which gave him a most gratifying recognition.

In 1838, he received from Berlin, the degree of "Doctor of Philosophy," and later he was elected to nearly every scientific association in America, and Europe.

But his pastoral duties justly claimed his best and most arduous labors.

He wrote in 1843 :

Our city has been unusually healthy during the past Summer-in my own congregation I have had but two deaths; but in a locality near the outskirts of the city, the "Stranger's Fever" broke out among the laborers on the railroad and swept off a great number of Germans.

As our German minister was absent, I attended to his duties and found my hands full. 
During the early part of his ministry in Charleston, he preached in German once a month. Believing that St. John's would flourish more if the ministrations were exclusively in English, he encouraged many of his German members to unite with the Germans in the city in forming a congregation, the services of which should be conducted entirely in German.

In 1841, the corner-stone of the German Church in Hasell street, was laid; and, in 1842, its first Pastor, Rev. Mr. Becker, arrived from Germany. This offshoot from St. John's required the fostering care of Dr. Bachınan and greatly increased his labors.

To Aunumon, after he had recrossed the Rocky Mountains.

Charleston, Oct. 31st, 1843.

My Dear Friend: My anxieties about you were relieved by your letter, dated from Fort Leavenworth.

I rejoice, friend, that you have escaped all dangers and are, to-day, in the vicinity of the coffee-pot, the feather-bed, and white faces.

I write this to meet you in New York.

T'ell me of all your discoveries. You must have things rare and new. $O$, how I long to tumble over the specimens. Talk of turtle-soup, and other delicacies; they are trifles, indeed, compared to such a treat.

Your specimens require an examination of three months. I cannot be spared from my pulpit, for a single Sunday - then how can I come to you? It is out of the question, therefore, I feel sure that soun 
you will be in my home with all your treasures, and we will discuss these subjects, as men ought to do who are in earnest.

Write to me on foolscap, fully, fearlessly; what long yarns I expect to hear from you. Had you the honor of knocking down the Buffalo and the Moose? Have you brought with you a Grizzly Bear, a Panther, and a Wild-cat? Out with your treasures! Let us overhaul them!

November 29th.-Fourteen new birds, did you say, friend Audubon-aye, it is a grand haul! and the new Deer, what about that?

I saw in a Western paper, that you had been mistaken for a Dunker, (a sect of Quakers distinguished by their long beards). I am not surprised-and I am glad to hear that the great beard is now cut off. I pictured you to myself, as I saw you in my home, when you came from Florida, via Savannah. You jumped down from the top of the stage. Your beard, two months old, was as gray as a Badger's. I think, a grizzly-bear, forty-seven years old, would have claimed you as " par nobile frutrum.

I shall take good care of your seeds; they will do best here, when planted in Winter. Send a few of each, that I may plant them as early as possible.

I long much to hear more of what you have accomplished on your expedition. I am a tea-totaller. I drink no wine and do not use snuff. I hope that you are able to say the same.

To Victor G. Audubon :

J. B.

Charleston, 1844.

My Dear Victor: To go ahead with my work, I must have books for reference. Charleston is a poor place for scientific works. I am often sadly at a loss for books I desire to consult. I send you a list of 
them. How I should like to look into them for only two weeks. Alas! what can I do? Sometimes, I have to set aside a species, for the lack of specimens and books. The books are to be found in New York and Philadelphia, but are expensive. I would not have you buy them; but could you not copy for me such articles as we need?

I enclose my plan. I wish always, a month before the time, that you would give me notice of the species you intend to put into the hands of the engraver, and send me, at the same time, the specimen. I cannot describe without it; I will guess at nothing.

I find the labor greater than I expected, and fear that I may break down and, therefore, cry in time, "Help me Cassius or I sink!" Writing descriptions is slow and fatiguing work. I cannot, in the careful manner that I am doing them, write more than three in a week. My son-in-law, Haskell, has copied forty-two closely written pages for me. I cannot shorten the articles, many of them I ought rather to lengthen. With patience and the help of all, I hope, however, to get on-the work may be lighter as we proceed.

The following is my daily practice: "I am up at 4 A. M., and work till breakfast, and recently, when parochial duties would permit, have kept on until 3 P. M.

The brush of my old friend, Audubon, is a truthteller. I regard his drawings as the best in the world. Let us be very careful to correct any errors of description that have crept in on the plates-I see a few in the lettering-they can be corrected in the letter-press; and let us be so cautious as to have nothing in the future to correct. There is but one principle on which a just man can act; that is, always to seek the truth and to abide by it. 
I am pleased with Owen's manner of dissecting. and his anatomical investigations in deciding on closely allied genera. He has, however, given very few of our American quadrupeds. While I do not wish the dissections of others to be copied, we may learn something from them of their manner of dissecting. Our motto must be: Nature, Trufin, and no Humbug!

November 29th. Your letters have been received. About the little mouse-I cannot see a needle in a haystack; or give it a name without knowing what it is. Friend, descriptions cannot be written, as a man works at making Jews-harps-so many dozen in a given time. My credit, as well as your father's, is so deeply concerned, that $I$ will not publish a day before I am ready. On the whole, I am rather pleased with the work thus far. If I keep my health, the letter-press (1st volume of Quadrupeds) will be finished in the Spring, and we shall not be ashamed of it. But if you hurry and worry - why -dyspepsia-temper, and the old fellow I have drawn for you (Satan), I don't know how to figure his horns and his tail! My business and profession is to keep him down-be careful that you don't wake him up! $* * * *$

I have such confidence in you, that I believe that you will do all that I wish. In doing this, however, you will have your hands full. Mine are soGod knows! Will not my old friend, Audubon, wake up, and work as he used to do, when we banged at the Herons and the fresh water Marsh-hens?

I have a story to tell you about our little mouse. I believe that I am the first man who has carefully compared the American and European mice-my notes are full. Tell Jostle to write me a letter, or what 
is better, come and see me work, and aid me in getting specimens.

Soon after Audubon's return from his perilous journeys among the Rocky Mountains, his friend first marked, with deep concern, a lack of that noble enthusiasm in his work, that had formerly touched all hearts, and made his studies and labors in Natural History a source of delight to himself and to all lover $z$ of Nature. It was supposed that in his eager search for specimens to carry on his great, work, he had overtaxed the strength of his body and mind. His friend and co-laborer wrote to him frequently, and sought to arouse and interest him in his former loved pursuits.

\section{To Aunumon:}

Do you want, friend Jostle, to hear about the Curassows? The vagabonds climb up the fruit trees in my yard, in spite of their wings being cut; and they pluck off the green fruit. Besides, they have nearly stripped my peacock of feathers; they peck away at the servants and race the children. They build, I find, on trees; the old male, as large as a turkey, built a nest on my mulberry tree, and sat bellowing like a Bullfrog, to invite the female up. Before she followed, she dropped an egg in the - yard; it looked like that of the Turkey-buzzard. **

During the summer of 1845 , accompanied by two of his daughters, he went North, attended a meeting of the General Synod, and spent a few weeks at Audubon's home on the Hudson River. 
Audubon and Bachman clasp hands as of yore. The beautiful Hudson flows at their feet; their grand-children play at their knees-and they are happy-very happy! Soon, however, Bachman's observant eye and loving heart detected in Audubon the unusual absence of mind, that for some time, had been noticed by his family and friends. Yet, during this visit, Audubon painted, with his unrivalled skill, "Leconte's Pine Mouse;" his friend is delighted, and thinks that rest is all that is needed to restore Audubon to health of mind and body.

In October, Dr. Bachman turned his face homewards. The Audubons had planned, that one of the daughters, in order to benefit from the skill of an eminent, occulist, should remain a year under their hospitable roof.

To his daughter Jane, in New York:

Baltimore, (Sunday night.)

My dear Jane: "I intended to write you to-morrow from Washington, but remembering that it will be a very busy day, I write to-night. I preached this morning: Julia and our friends accompanied me to Church. I hope that we have all had a very profitable day.

Julia enjoys everything; friends have taken entire possession of her. Sight-seeing involves many fatigues and labors for both mind and body-and, as I approach nearer home, I find myself more and more anxious to move on. Were it not for Julia, I should not stop at Washington.

I have left you, my daughter, in New York solely for the benefit of your eyes; try to be as happy as 
you can during the cold winter which is approaching. But at your age, I did not mind the cold. Like Frank in the Reading book, I used to wish that Winter might last all the year.

Next to your own dear parents, you are with the friends who love you most in the world, and will try to gratify every wish of your heart. Do not make yourself unhappy about your separation from your mother. Lynch has become an excellent nurse, and Aunt Maria and I, will not let mother want for any thing.

You must try to think that this temporary separation, will be best for your mother and yourself. What we cannot alter we should learn too, to bear patiently. Trust in the Wise Disposer of Events, who does nothing in vain, and sends even visitations and sorrows to work out His own good purposes.

The last time your mother went to Haskell's, she improved, and I shall coax her to pay another visit to Totness during the winter.

* *

Love and thanks to Victor, and to all the Audubon family for their great kindness to you and to us during our visit.

Wherever the father and daughter journeyed, the classical form and face of his daughter, Julia, was the subject of comment. The attention she attracted was no doubt gratifying to his fatherly pride; yet it seems to have aroused a fear in his heart, that the adulation bestowed upon unusual personal beauty might be injurious to the spiritual development of his child. Julia, perhaps accustomed to admiration from childhood, seemed to be scarcely conscious of it. She was frequently requested to sit for her likeness, 
but always declined. Reserved in manner, and of a temperament so unlike her father's; it was not until several years later, that he discovered how entirely he had misunderstood her character.

On his return to Charleston, he wrote to Victor Audubon :

\section{October 31st, 1845.}

We arrived at our own dear home, well, though much fatigued. My good wife is not suffering today.

While at Washington. I worked like a horse among the quadrupeds-Peale assisted me.

The specimens are here before me, ready to be handled, also the Elk horns-I thank you.

I see De Kay makes two species of our Northern Grey Squirrel-I think it an extraordinary mistake. The three you figured are in Summer pilage, without hair-like tufts on the back of the ears. My opinion is, that the Squirrels of the first summer get no tufts the first Winter; but the second Winter the tufts appear, and return always. I once obtained in the New York Market, three with tufts in December. I remember too, that when a boy I caught them in traps in Winter, they had tufts; and in Summer, they were all Grey Squirrels; and I was much puzzled. Now friend, can't you ransack the market for caged squirrels, and examine for yourself?

It is late, and I am weary, weary. To-morrow I shall finish this.

* *

\section{January 1st, 1846.}

Dear Audubon-As I do not like to disappoint you in anything, I send you one of the articles. It is about a fair sample of the whole-some please me far better-there are a dozen superior to this, whilst 
others have less interest. I try to incorporate as much as I can of your own, but, in most cases, your notes have come too late.

You see how plain Haskell writes: I should think that by this time, he has copied three hundred pages as correctly as the inclosed. I should have sent an article from those I prefer, but they contain blanks to be filled up when I get the desired information.

March 6th, 1846.

For the last four nights, I have been reading your journal. I am much interested, though I find less about the quadrupeds than I expected. The narrations are particularly spirited, and often instructive, as well as amusing. All that you write on the spot, I can depend on, but I never trust to the memory of others, any more than to my own. I admire a remark of Dr. Wright's on this head. I wished him to give me an account of the glands of the Skunk. He answered, "I must write for my notes, I cannot depend for these particulars on a fading memory."

Poor Dr. Wright, he spent two weeks at my house; then, at his request, I took him to Aiken. I have now just returned from a visit to him; he is able to drive out, but his cough has increased, and I fear that we shall have to abandon all hope of his recovery.

To return to your Journal. I am afraid that the shadows of the Elk, Buffalo, and Bighorn hid the little Marmots, Squirrels and Jumping Mice. I wish that you had engaged some of the hunters to set traps. I should like to get the Rabbit that led you so weary a chase. Write to S., and find out some way of getting - not his princess brain-eating, horse-straddling squaw, but what is better than such a specimen from the Black-foot country-1st, The Skunk; 2nd, Hares, in Winter colors; and 3rd, 
the Rabbit that you chased. In your Journal your descriptions of Buffalo hunts are first rate. I don't like my article on the "Beaver," I shall have to write it over again. If I could only horrow Tem. minck's large work. Every library here is open to $\mathrm{me}$, and you would be astonished to see the number of books in my own library; but the scientific works of close comparison are not among them. I had written letter after letter, but might have saved ten dollars postage. The answers from my native State brought me no information. One letter to Dr. Wright, last year, solved my difficulties, and confirmed my old views-his letter was like a light in a dark chamber. Alas! he is not long for this world. His very love of science causes him to wish to live. I am truly glad that he came to us, instead of going, as he proposed, to South America; here he receives every attention. When he parted from me, yesterday, he told me that we should not meet again-I believe that he is mistaken. As soon as I have sent off your first twenty-five numbers, I shall go and spend a few days with him. Love to Jane and to the whole family circle. $* * * *$

To his Daughter Jane:

March Sth, 1846.

Winter with us, to all appearances, is past and gone. The Jasmines and Honeysuckles are just beginning to show a few flowers. The Plum trees are in full bloom. To-morrow, the first rose will open-a beautiful Cloth of Gold. I wish I could give it to you-imagine that you have it. Could I send it, the heart would go along with it.

Your mother misses you-her faithful nurse; but $\mathrm{L}$. is a treasure, and is now reading aloud to amuse her. William enters college next month. Little 
C. is obedient and excellent. I have not had occasion to reprove her for six months, and she is growing in size and improving in knowledge.

The whole family send you a thousand remembrances. Love to the Audubons. *** J. B.

P. S.-My article on the Beaver, that did not please me, I have re-written, and Julia has copied it clearly for me. Say to Victor that it is now ready for the press.

To John Aunubon :

Charleston, March 21st, 1845.

I find the describing and writing the histories of animals slow and tedious work. I have been nearly two days, until late in the evenings, hammering at the Porcupine, and the article is not yet quite finished. * * *

Victor writes that I am growing savage. True, my boy, for I am the school-master just now, and find him a little lazy, and I am lashing him to work. When he behaves like an industrious boy, I shall put him at the head, and give him sugar plums.

18th. I have suffered so much with inflammation of the eyes for the last four or five days, that the Doctors insist that I have overworked them, and have made me give up writing for some days. Sister Maria hid my spectacles, and I only found them. after all had gone to bed.

If to-morrow Doctor Horlbeck should allow me, with a shade over my eyes, in an hour I could examine my specimens. Every book that you have lately sent me is a treasure. * * * *

My daughter Harriet, and son-in-law Haskell, are with us. 
P. S., March 22d-Within this hour, a grand-son has been born to me. Harriet and the boy are doing well. I hear the fellow's voice-his lungs are strong. $\mathrm{He}$ is to be called "John Bachman" (Haskell.)

Great was the joy of the grand-jrarents over their first grand-soll. Mrs. Bachman grew a little stronger, as she watched by the cradle, and made little garments for their boy.

To Victor Audurun :

April 6th, 1846.

My predictions and fears, with regard to my friend, Dr. Wright, have been verified sooner than I expected. His body, enclosed in a leaden coffin, was brought to my house from Aiken, yesterday. I shall forward his remains to his friends in New York, by the next boat. I grieve much for the loss of a man of science-of skill in his profession-of a pure heart and useful life. Mrs. Wright is with us; she leaves to-morrow, in company with friends for New York. Will you, for my sake, take her to your home for a few days, until the body reaches New York? Her friends will meet her there, and they will take the remains to Dr. Wright's home in Troy.

We enjoyed John Audubon's visit, and shall be very glad to hear of his safe arrival home.

Mrs. Bachman's health, for a fortnight, has been improving. Harriet and the boy are quite well. Haskell has just left us for his plantation. * * *

J. B.

To Audubon:

April 7 th.

Yesterday Mrs. P., the friend of Mrs. Audubon, called on us. We were much pleased with her in- 
telligence and agreeable manners. She has now seen every member of our family-the little grandson in the bargain. She was present, too, at his baptism. * * I cannot conceal from you, friend Audubon, that my spirits lately have been depressed; nor can I conceal from myself, that my dear wife's sufferings have shattered her frame, and that she has been losing strength. I trust in God that there may be some decidedly favorable change, else it is problematic, if her strength will permit her to come to you in June, as you have planned-this must be left to the development of time.

The proof-sheets have not been received; I hope that they will come to hand, that I may correct them next week; but I work now in a spiritless manner.

This is Saturday, and I am unusually busy. Mrs. P. will tell you all about us, and Jane will ask many questions about everything and everybody at home.

Monday.-The Letter-press has been received, and returned corrected. I am hard at work on the articles during the few. hours left to me from a thousand calls and interruptions. We have a small family-only my three school-children are at home, the others are away, and the house seems very quiet-too quiet.

To Victor Auduron:

April 1st, 1846.

For weeks I have not answered your letters. I had taken my poor, suffering wife to Totness, (Haskell's summer residence), ninety-five miles from Charleston. I left her with my daughter Harriet, improving as I thought. Suddenly her Ticdoloreux returned in frightful paroxysms ; the physician's skill was powerless to contrul the pain, and she became 
so excessively weak that, every day, for two weeks, I feared the end was near. Haskell sent for all the children. I was wretched; I cannot look to the event of losing my beloved wife without feelings bordering on despair.

Sunday night.-A favorable change occurred yesterday, (Saturday). I took the train and reached Charleston in time to fill my pulpit, and shall return to Totness by to-morrow's early train.

I had hoped that the change into the country, would benefit my dear wife. Even now, I ain not entirely bereaved of hope, but my prospects are dark-very dark. I shall not let her leave me again. If she could only bear the journey, and be at home once more, near her own physicians, in whom she has the utmost confidence. Meanwhile I have brought my daughter Julia home with me, to take care of the boys, who return to school.

Your queries I cannot answer until I have my mind again - at present I am unable to think or to attend to anything.

Charleston, April 8th.

"The Electric Battery" has, at length, brought relief to my poor, suffering wife. She is to-day comparatively free from pain, though very weak.

I have brought her home again. You will hear from me soon.

J. B.

Mrs. Bachman, to her daughter, Mrs. Wm. E. Haskell, at Zante, S. C.

Charleston, May 1st, 1846.

My dear Harriet--"I am delighted to hear that Julia and yourself had such a pleasant journey to Zante. Julia writes me that Zante is a lovely place; and that the little Bachman is well and good. I felt 
lonely after you left me, and thought several times that I heard the baby cry. Had I not made up my mind to go North this Summer, I should have tried to spend much of the time with you; but I long to see Jane and bring her home with me.

By my writing, you will see that I am weak and nervous-though I am better than I ever expected to be. * * * * * Harriet B.

John Bachman to Victor Audubon.

Charleston, June 6th, 1846.

The Mouse from Fort Union is new. I would like you to figure it and return it then to me, that I may name and describe it. Have patience with me, remember I have many important, and unaided Church duties to perform.

I am happy to be able to say that my dear wife has been well enough to take several drives, and has been able once to go to Church. I hope to bring her to you in a month's time.

Mrs. Bachman to her daughter Mrs. William E. HASKELL.

June 21st, 1846.

Last Sunday I attended service, both morning and afternoon, but I have not been so well this week.

I am rejoicing over the good accounts of the greatest of grandsons-how I would like to take a peep at him, I should hardly know him now.

I wish that circumstances would allow me to spend a month with you before I leave for New York, but it cannot be arranged.

Your father thinks that we shall be ready to sail, about the first week in July. 
I trust that my health may improve, and that I may have the strength to assist your Aunt Maria in taking care of my family. Love to Julia and $\mathrm{Mr}$. Haskell-kiss little Bachman a thousand times for me.

Your affectionate mother,

H. B.

Our Mother, was a skillful needle-woman; when an unfortunate rent had been made in some delicate fabric, no hand could repair and conceal the defect better than her's. We brought to her our broken toys to mend; and, in our games, she would ever straighten the bent pins for us. Her chamber was the quiet, peaceful spot, where we took our books to study a hard lesson, or to write our school composition. Frequently, and nut unwillingly, we shared with her, the dainties provided specially for the invalid. Ilow many daily lessons of fortitude, patience and unselfish devotion to God and duty, her holy example taught us in the days of childhood.

Years after, when the gentle sufferer was with her God, we found a pencilled diary, in her hand-writing-it was a revelation to us. The little book was intended for no eye but her own. It was dated from the home of her daughter, Harriet, (Mrs. Haskell,) and written during her absence from her husband. It revealed to us, the strength and beauty of a wife's devotion to her husband-the little prayer of thanksgiving, recorded when she had been comparatively free from pain during his visits to her, and could be a helper, not a hindrance, to him in his arduous labors, opened to our view a singularly pure and 
useful life. She never objected to a separation from her children, when it was for their pleasure or benefit, though she missed them sorely, and longed for their presence. Which of us could forget our father's strict and repeated injunctions to us as he gave the parting kiss-"Write frequently, my child; remember, if you neglect to do so, your silence will make your mother anxious and unhappy." It was no wonder that her husband and family loved her with almost a passionate tenderness. 


\section{CHAP'TER XIV.}

Affliction.

DEATH OF MRS. BACHMAN-LETTERS TO THE FAMILY-LETTERS TO AUDUBON.

I 1846, death stealthily entered again into the home of the Pastor of St. John's.

In the following letter he gives the sad details:

To his daughters, Harriet and Julia :

Charleston, July 16th, 1846.

Yesterday, I announced to you the melancholy event that has brought sorrow and mourning into our home, and rendered it very desolate.

I was not, my children, without the hope that your mother might be benefited by the proposed trip to the North, that she was anxious to undertake.

We were providentially detained in Charleston longer than we intended, in consequence of no vessel being in port. On Saturday several arrived, and on Monday I selected a state-room in the "Carolina."

On Sunday night your mother awoke with an attack of Ticdoloreaux. About 2 A. M., she fell asleep; but I could not sleep from agony of mind. I felt that I was about to leave $m y$ poor sufferer at. the North, without knowing if I should ever see her again. I feared to move, least I should disturb her; but at 5 A. M., when I rose, she was sleeping calmly. 
Breakfast was partly over, when, to my surprise, she came to the table; she was looking very feeble. After breakfast, I told her that I was going to select a state-room in the "Carolina," she assented. Having made my selection, and visited the sick in my congregation, I returned home and found that your mother, in my absence, had suffered from a severe attack of pain. Dr. Horlbeck was passing our house at the moment, he came in, and himself adminis tered the usual dose of a mild anodyne. I left the two girls, L. and C., with their mother, while I lay down to take a little rest. I awoke about 4 o'clock P. M. ; she was still sleeping. I folt her pulse; its weakness alarmed me. Dr. H. was summoned. She never revived, and at 7 P. M., breathed her last, as quietly as an infant falls asleep. God's will be done! But ah, the shock! The suddenness! We were all stupefied. I know she is at rest with her Gorl, that $\mathrm{He}$ has taken her to His own peaceful and joyful kingdom. But our home is lonely and my heart desolate. She was ever a loving wife, the soother of all my cares and sorrows.

Dear children. you know how fond and devoted a mother you have lost-one that watched over your interests, and gave to you, next to her God, her thoughts and affections.

Yet, let us not sorrow, as those who have no hope. Let us cherish her memory; imitate her virtues; her love of duty; her purity of heart; her integrity of life, and her love to her God and Saviour.

While I am always glad to have my children around me; yet I do not say, "Come home"-that you must decide upon for yourselves. Just yet, you can contribute nothing to my happiness-comfort must first come from a higher source. I shall write often to you.

*

*

*

J. B. 


\section{To his Daughter Jane, in New York.}

Charleston, July 18th, 1846.

"I wrote you two days ago. My mind was so confused at the time, that I cannot recollect distinctly what I wrote.

My children have experienced a heavy loss, but ah! the heaviest falls on the devoted head of their father.

Yet it is God who rules our destiny and orders our lot. His arm reaches from heaven to earth. He who has given the life that now is, has also left us the promise of that which is to come. When a few years shall have passed away He will send his angels to call us home. There we shall meet our Lord in the peaceful land, where sorrow, sin, and death are unknown. There our loved ones will be restored to us, purified from all imperfections and wearing the crown of immortality.

My daughter, cherish these high hopes of our religion, they are angels of Mercy sent to guide us through the storm, and to lead us to the land beyond death and the grave.

God has promised never to leave us, or to forsake us. It is true, God has sent death into our family and caused our hearts to bleed-but then it was the virtuous dead, who died in the Lord. Has he not saved us from dishonor and disgrace-evils worse than death?

It is true, that we ardently desired to retain our loved one here-sufferer as she was-but, was it not, after all, a selfish wish? She was an intense sufferer-her moments of rest and joy were few and far between. Long she had lingered with us- at length only a faint shadow of what she once was. Then her Maker sent her a gentle, quiet rest from all her sorrows. O my beloved, sainted wife, may your 
husband learn from you, patience, gentleness, and submission!

I pray for submission to God's will, and I know that He will, in His own good time, enable me to say: "Although the fig tree shall not blossom, neither sliall fruit be in the vines; the labor of the olive shall fail, and the fields shall yield no meat; the flocks shall be cut off from the fold, and there shall be no herd in the stalls; yet I will rejoice in the Lord, I will joy in the God of my salvation."

My daughter, you were long the watchful, faithful nurse of your mother. How tenderly and cheerfully you performed that duty, we all know full well ; and your mother's loving remembrances of you, proved how deeply you were fixed in her inmost affections. Now, when you place your head on your pillow, or bend your knee in prayer before the Majesty of heaven, there will be no painful reflections of filial duty neglected. You need not fear to meet the spirit of your mother in the peaceful kingdom of your blessed Saviour.

May I not hope to hear that you have bowed submissively to this call from a merciful God, and that you have been enabled to say "Thy will be done!"

All join me in love to you, and to every member of the Audubon family. $* * * *$

To Victor Audubon:

JULY 18th, 1846.

"When your last letter reached me, I hoped that we would soon converse together in person, and have opportunities to solve the doubts contained in your letter, but God has ordered it far otherwise. In God's name, try to coinfort our poor, dear Jane !

I am lowed down, and almost distracted with anxieties; the latest is, that Haskell's account of 10 
Julia makes it necessary for me to go to her. I will leave in the morning's train. In a few days I shall let you know my further movements. $*_{*}^{*} *$ *

\section{'To his Daughter Jane, New York:}

Charleston, July 22nd.

I have just returned from Totness, where I went in haste on Sunday morning to see Julia; who, on hearing of our sudden loss, fell into a swoon, and, on recovery, her mind wandered. When I reached Lewisville, where the cars left me, I found no conveyance, so I walked the six miles. It was a cool day, and I felt no inconvenience from the long and unaccustomed walk. They had not expected me on Sunday morning, so had not sent for me to the railroad.

Harriet's good husband, their lovely boy, and her family cares, diverted her mind from the poignancy of grief; but to our poor Julia, it was the one and all-engrossing subject. She was so much better when I reached Totness, that to my surprise, she came to meet me. In her chamber, I saw religious books; judging from the passages marked, she is perusing them carefully.

Thinking that there would be less to remind her continually of the loss where she is, than if I took her home, I proposed to her to remain with Harriet for the present, and she has consented. I have a season ticket on the railroad, and shall go up once a week.

Our friends are very kind and attentive to us, and if sympathy can afford relief, surely we shall find it.

My mind is peculiarly constituted; in grief, I like to be alone. In solitude, I can learn the path of duty, and plan how to regulate my feelings, and 
govern my conduct, then, I am generally able to rise from despondency and to look to God for aid and strength to go on in the performance of duty. I was prepared to preach last Sunday, but was prevented by the sudden call into the country. This evening, (Tuesday) I have had my usual lecture, and was able to perform the whole service.

$$
\text { July 26th, (Monday). }
$$

Julia has written to us; she is still much depressed; I must go to Haskell's and try to cheer her as well as I can.

We heard yesterday from Wilson. He wrote a sensible letter, full of feeling. Mr. Lee, (his teacher) proposed to him that he should dispense with his lessons for a few days; but he answered that he thought, if his mother were here, she would advise him not to stop his studies, and he continued his recitations in his class. He promises to try to do everything that his mother would desire. Wm. and C. are studying their lessons preparatory to going to school. L. is not well enough yet, to go out. I am sorry to see symptoms of dyspepsia in one so young.

Yesterday I preached twice. I went with a heavy heart; but God supported me. I pray God to bear you up in His arms of love, and to enable you to bow to His divine dispensations.

I am ready, my dear Jane, to comply with your wishes in regard to your return. I have written to Doctor Trudeau to get his opinion; he will determine if you may come at once, or wait until cooler weather; your interest and your wishes shall be consulted. My love to all the Audubons, especially to the children.

Your affectionate father,

J. B. 
Chåleston, July 27th, 1846.

I thank my God, my daughter, that you have been enabled to view this affliction in its true light. I am surprised now, that I did not foresee the sad event; the night before her death, she told me that I would not have her with me much longer. God, in His mercy, saved her from the pain and consciousness of the parting hour. God bless you and comfort you.

$$
\text { July } 15 \text { th. }
$$

"It is Saturday, and I am as usual, much engaged; yet, I cannot feel that my duties are discharged until I have written to you.

Yesterday, I returned from Totness; I spent one day there and consumed two others in going and returning. Haskell sent for all the family. I have taken them to Totness, and I hope that the change of air, scenery, and sinciety, may be beneficial to themthey needed a change.

I am alone at home. I think I feel better, when no one interrupts me, and I sit in my quiet corner, preparing for my many duties and responsibilities. Yet, if I had you all with me once again, and all quite well, I should draw around me the materials for happiness that are still left. I am looking up to our heavenly Father to sanctify this affliction to us, and to shed peace and comfort on our lives. May God in His mercy guard, preserve, and bless us. *

\section{To Victor AUdubon:}

\section{November 5th, 1846.}

This is Thanksgiving-day. It is raining, blowing and snorting as if old Boreas, Neptune, and all the sea-devils had combined to frighten the wicked in- 
habitants of 'Terra-firma. Well, they say that "it is an ill wind that blows nobody any good," so, after preaching to about twenty half-drowned people, I am seated by the fire, ready, without fear of interruption, to write you the names of your recent drawings.

There are the five-all plain sailing; the sixth, friend-here is no fun.

Short-tailed Marmot. By some unaccountable mistake I never saw the specimen in London. I am mortified. Lewis \& Clarke mention, but do not describe it. Short-tailed is an improper name; its tail is longer than many others. Now, we are to describe it; but not without a close examination of the specimen. John has access to it in London. Waterhouse will verify his measurements; but let him not hint, that it has not yet been described, as those Zoölogical boys, would name it an hour afterwards. Meanwhile, let Victor send me an outline of the drawing, dabbling on it a little of the colors, to give me an idea of it. $O$, that $I$ had wings just for an hour, that would carry me at telegraphic speed to London, to see the specimen for myself !-but here I am seated, without wings. Write at once to John. The second and third proofs have come to hand. I have received the opinion of the post-master. We are allowed to write corrections and additions to our proof-sheets.

We wrote you of Jane's safe arrival. She cannot say enough of your kindness to her and your thoughtfulness of her comfort. Harriet and Haskell both have been ill with fever. I brought them home with me; they are well enough to be down stairs to-day. Julia's health continues very delicate.

P. S.-To Audubon: The snuff-the snuff, it is here! I have just taken a pinch, and the ladies 
have blown you up-sky-high, for teaching me such a bad practice; I say, however, that you beat me all to pieces in that art. Love to all, especially, to my little pussies, Lucy and Harriet. God bless you. * *

To Audubon :

March 13th, 1847.

I am seated at daylight ready to write you, but I am not sure that you deserve a letter-are you all frozen up, or only lazy?

At last the letter-press has been received, and the review of the first volume. The printing of the former is excellent. I could review it and row the authors up Salt River. There is something in Mrs. Glass' (Cookery-book), Boil your fish after you have caught him, and something of old Squib, (the gradener), Put on some well rotted manure-if you have any. However, I only hope that the Second Volume may contain as much information as the first. The review is quite clever; the man knows more of the history of American naturalists than I thought. He gives us old men rather too much butter and sugar-gives a thundering broadside into DeKay, and abuses Harlan a little too much.

Of late, I have spent money, and given much trouble to my friends in obtaining Opossums-by the twenties. I should like to reward the hard laborers with books-for this purpose I have taken twelve copies, and should like to have six more.

I have two new subscribers for you, (the copies must be bound handsomely), viz: for The Charleston Library Society and Hon. Mitchell King.

I send you to-day, by the Brig "George," a Wildturkey. I have carefully kept her, doctored her warts, and she looks pretty well, only her wing- 
feathers have come out white. I also send a box of rose-trees for the ladies.

P. S.- a cold North wind has sprung up ; I shall not send the turkey and the roses until wind and weather change. * * Maria, the girls and children all send love; they are well, excepting my daughter Julia.

J. B. 


\section{CHAPTER XV.}

\section{Father a Daughter.}

WHEN John Haskell realized that a fatal disease was daily weakening the cords of his life, and that another hand was to write the Biography of his Grandfather-a work that his heart craver to be permitted to accomplish, he wrote to his aunt, C. L. B.

"I have ceased to expect, or to hope for recovery; I am changing the hope of earthly life, to the greater hope of eternal life. You may have to write the Biography. I would, in that event, say, that it was my intention to devote a chapier to the beautiful life and death of my Aunt Julia. I find many letters relating to her in my grandfather's own handwriting (and others); use them. Thus her exquisite life-the result of his-for she was his daughter, may be told incidentally in his own words."

There are wonderful histories written and graven on human souls, many of these will be revealed only in the light of eternity, but, in the following pages, the Pastor of St. John's opens his soul to the reader. He has thrown on the canvass a life picture, that needs no coloring from fancy or fiction.

We have before alluded to the beauty of Julia, (Dr. Bachman's fourth daughter) - a beauty of countenance and a grace of form seldom found combined. 
With his high thoughts, he felt that any special gift was a talent, that called for a special consecration of the same to the Giver. His elder daughters, when they were of ripe age, had rejoiced to renew. the baptismal vows made for them in infancy.

With the same teachings, under the same influences, how was it with Julia? He was jealous for his Lord; not the world, but the Master, should have the sweet freshness of her youth. With watchful eye and prayerful thought, he followed her day by day. Frequently he attempted to draw aside the veil of reserve and timidity that concealed from him her heart, and her mind; yet all his efforts appeared to him not only unsuccessful, but every new failure seemed to add another fold to the veil that hid the inner sanctuary from his eager gaze.

She was twenty years of age at the time of her mother's death. From that date the family letters contain allusions to her failing health.

Her father wrote to John Audubon:

June 19th, 1847.

I have been suffering with an inflammation in my eyes-they feel as if they had sand in them. I have pressed Sister Maria into service. I am seated with a patch on each eye, while I dictate this answer to your letter. I am not gloomy, only hoping tor more light, better eyes, and better times.

Before entering into the perplexing part of the letter-the naming of the species-I must speak of family affairs, Julia's health has failed steadily. I took her, as you know, to Aiken for a few weeks. Her cough is distressing, and she has fever every 
day. In a couple of weeks I shall take her to the Virginia Springs. Her aunt Maria and her sister L. will accompany her. I expect to go with them as protector, and remain with them three or four weeks. * * *

\section{Richmond, July 10 th.}

We have advanced thus far on our weary, anxious journey. The physicians were hopeful, but my views of Julia's case are unfavcrable. I notice that she speaks continually as if hopeless of recovery. I try to cheer her.

My eyes will not permit me to write more. Direct to the Red Sulphur Springs, Virginia.

To John And Victor Audubon:

Red Sulphur Springs, July 28th, 1847.

Your and Victor's letters we found waiting for us here.

We have had a fatiguing and sad journey over these rough mountains. Julia was so weak that we were compelled to rest a week at the Salt Sulphur, another at the Sweet Springs, and a few days at the White Sulphur. I will not pain you by giving a detail of our adventures, anxieties, and sufferings. I came to gratify her wishes. Alas! the shadow of a hope that I had entertained is vanishing. I scarcely dare turn my mind towards the weeks that are to follow this.

Continue to write and send us a newspaper or two. We have none here, and I feel almost cut off from the world.

Every one seems full of sympathy and kindness. We have good medical aid, nurses and friends. My eyes have improved.

I am looking out of my window on the grand, 
romantic and lovely scene before me, in this sweet valley, surrounded by mountains, covered to their highest peaks with rich and varied foliage. In the buildings around me what a contrast!-night and day I hear coughing.

I meet with pallid faces, and see on many a cheek the hectic flush. How terrible is consumption! It seizes with a deadly hold, weakens the cords of life, day by day; and only relinquishes its fatal grasp when life is extinct. How sad to see this beautiful garden of earth, disfigured by graves and monuments of the dead. But so it is; and man, the child of the dust, must.bow submissively to the will of heaven.

August 2d.

The shadow of hope which I sought to indulge in has given place to the saddest of realities; disease is sapping away the fountain of life-our Julia will never leave the mountains alive.

I have received all your letters, but I do not feel able to reply to them,

All send love.

August 10th.

Since I last wrote, hope has arisen anew in my heart. Four days ago Julia revived, and with a little assistance was able to walk about the room; this slight improvement has fed our hopes. She has little appetite, but likes birds. I have shot for her pheasants, ruffled grouse and partridges; but all birds are scarce in the mountains; sometimes I walk or ride six or seven miles, without meeting even a sparrow. Animal life seems almost absent on these mountains; I scarcely hear the hum of an insect. How sad this place is to me! It is thronged with coughers, there is around us every form of disease, and we are daily distressed by sad sights and melan- 
choly tidings - the very music sounds to me like a dirge.

Gen. McD., of this State, and the P - n's, of Columbia, are here on a visit to their sister, Mrs. McD., who lies ill in the room adjoining our's, and we have their attentions and sympathies.

If Julia could gain strength enough to travel very slowly over these mountains, we might yet take her to her home.

May God direct and aid us, and give us fortitude to bear the heavy impending bereavement.

Many of the visitors at the Red Sulphur would willingly have accompanied Dr. Bachman in his tramps after game for his daughter, but they saw that to weary himself in her service helped his sad heart.

The children were on the watch for his return, and would run to the foot of the hill to bring home the birds for him, and were well pleased to get in return a pleasant word or smile. They would linger around, too, if the carriage stood at his cottage door, to catch a glimpse of his daughter's lovely face.

The beauty that attracted so much attention has been described thus:

"Features regular and classic; complexion fair and transparent; hair of a rich brown, worn in light curls; eyes full and expressive-a true grey (always changeful in color); the mouth delicate and well formed." But a face like hers, when lighted up by the soul, possesses a spiritual beauty, that neither brush nor pen could ever portray.

Soon a day came when the invalid was too weak 
to take her accustomed drive. Her father saw her losing ground day by day. He noted, besides, her ever increasing watchfulness over those at her bedside, in her anxiety lest prolonged vigils should exhaust their strength. As he read to her the Word of God, he eagerly marked her rapt attention and the tender light in her eyes; yet, as a Minister of God, he craved fuller evidence that her heart was entirely fixed upon her God and Saviour.

\section{August 22d, 1847.}

My dear Children-There has not been for an hour since I last wrote, a favorable symptom in our beloved Julia's disease. Dr. Burke has watched with us, at her bedside, night after night. We have seen her poor frame slowly wasting away from suffering, She is yet lingering on these mortal shores; but we cannot expect to have her with us, for many days longer.

To Victor Audubon.

August 29th.

Alas, the only change is for the worse. It gratified our poor invalid to have birds, and I travelled miles daily through the mountains to procure them; now she cannot eat them-my occupation is gone, I have no employment, and seem daily less fitted for any. God help us in our sorrows!

I still cherished the hope that we might have the satisfaction of removing her to our peaceful home. Now I know that I must abandon it wholly. * *

As the deepest, highest love ever desires to manifest itself in service to the beloved, the very difficulty he experienced in procuring game, among the 
bare mountains, to tempt his daughter's failing appetite, was to him a source of satisfaction; now he writes gloomily-"My occupation is gone, I have no employment left." Thus we oft-times cry, while the Master is but preparing us, for nobler duties and far higher service.

Red Sulphur Springs, Monday, Sept. 6th, 1847.

My dear Children-My last letter detailed to you the hopeless, almost dying condition of our beloved Julia.

O! how I have wished, that when this hour came, she might be in her own blessed home, and close her eyes, in the midst of her loved ones, and be laid to rest, at the side of her gentle, sainted mother.

Dear Julia, I find, had long been deeply concerned with regard to her religious state, and had sought the light of God's Word with prayer.

1 had left my home, my other children and other duties, to devote myself to her. I had brought her over these rugged mountains, carrying her in my arms in and out of the carriage. I had guarded her cabin from noise and intrusion; and, now, it was my duty, to instruct and to aid her in her search after perfect peace. Fervently we prayed together, and long we wept. Still she desired more light, greater assurance of forgiveness, and stronger evidence of God's mercy. Our prayers have now all been heard. Yesterday was a blessed Sabbath to us. Through the mercy of Him who died for her on the cross, she has found hope, comfort, peace and joy. For hours yesterday, she spoke of the past, the present, and the future. Her eyes were bright and her mind clear; her perceptions keen and her judgment strong; her words were submissive and her 
prayers fervent. Her whole soul was so full of the love of God, and the mercy of her Saviour, that she seemed, almost to forget her great sufferings. The fear of death was entirely removed, and she triumphantly exclaimed, " 0 ! death where is thy sting, $O$ ! grave where is thy victory! Thanks be unto God who giveth us the victory through Jesus Christ our Lord." We all united in the Holy Communion. The tender messages of love she sent to each of you, will be detailed to you by your aunt and sister.

She began with " my dear sister Jane," and ended with "dear brother (W. E. Haskell), who was so very kind to me when my mother died, and prayed for me, when I could not pray for myself and was ready to despair." I have no words to express the propriety of her thoughts and the fond devotion of her language.

Yes, there is a solemn reality in religion that effects a change in the whole mind and heart, and brings under its influence every thought, word, and action. This seems to be realized here. All music is hushed. Many sympathizing friends are standing around our cottage weeping; and a solemnity and stillness reigns throughout this hitherto noisy and thoughtless throng.

IVill you not, my dear children, seek for that religious knowledge and firm faith, that sustained your departed sisters in their last hours of trial, and cnabled your meek and gentle mother to pass through the world loving and beloved. Let their Saviour be our Saviour, and their heaven our everlasting home.

$$
\text { With love to all: **** } \quad \text { J. B. }
$$

September 18 th, 1847.

I detailed to you daily, my dear children, Julia's bodily condition and her peaceful frame of mind. 
When I closed my Jetter on Monday evening, neither Dr. Burke, her kind physician, nor myself, believed that our beloved Julia had strength remaining to survive through the night. I was more than satisfied with her state of preparation for the approaching event, and prayed for her removal in the same peaceful, hopeful and confiding frame of mind.

Her paroxysms of pain were frequent, but she would rest afterwards with her eyes closed. At daylight, as I sat by her bedside, she breathed so softly that for an hour I listened, expecting to hear her last sigh. She opened her eyes. "Father,' she said, "I am ready now for the morning prayer;" and as we prayed, she repeated my words. When I had concluded, she begged me to lie down and rest. To please her I left the room. An hour later she called for me. "Father," she whispered, "You remember Miss C. S., who was so kind to me at Aiken; who came every day to comfort me, and, by her words and example, to remind me of my duty to God? When you return to Charleston, tell her how gratefully I remember her kindness, and tell her that the friend with whom she sympathized so deeply, is more happy on her deathbed than she can find words to describe." She asked for her dear sister L., and the scene of tenderness and love exhibited was overpowering. She detailed in language appropriate, her convictions from time to time; her subsequent coldness of heart; her prayers and her fears, amounting almost to despair. She told of the gradual steps by which the Almighty hand had led her to see her need of a Saviour, and the light that broke in upon her mind; the assurances of pardon and the bright hopes that raised her above the fear of death. She called down upon her sister L., her watchful nurse and companion, the choicest mercies of heaven. She spoke of the joyful meeting with 
mother and sisters that awaited her. She was by this time greatly exhausted. I bade her close her eyes and try to rest. She obeyed and slept about half an hour. She opened her eyes, a thought had come into her mind ; "Father," she said, "Should one, so much blest as I have been, spend an hour in slumber? Should not every moment of the short remnant of life be spent in praising my blessed Redeemer?" When I told her that nature required repose, she assented. A little later, "Father, when the time comes, you must pray with me, I wish to go to heaven borne on the wings of my father's prayers." The thought was original and beautiful, as well as tender and confiding. She had paroxysms of pain, and at intervals slight wanderings of mind. We moistened her lips, and she became quiet and composed. She was evidently dying; once more she spoke: "My time has come. Now, father, now pray." Her hands were clasped, and her eyes, full of animation and hope, were raised with an intently fixed gaze toward heaven. I looked upon her face, the spirit had departed, and that broken prayer. begun for the dying, ended in imploring mercy and compassion for the stricken members of her household. Dr. Burke, her kind, intelligent physician, was supporting her head, and he closed her eyes. In death her face was like that of an angel, but her short religious life was brighter still. O my children, will you not profit by this lesson!

\section{To the Audubons:}

Yesterday, (Tuesday, September, 7th), at two o'clock, our dear Julia, the object of our pride, and recently of our loving sympathy and unwearied watching, was called to her peaceful rest. Her body will be interred this afternoon.

I have written down her messages to you all, en- 
deavoring to use her own words, but the love that shone in her countenance, and the fervor of the soft and gentle tones of her voice, no language can convey.

For some time before her death she had expected the event and sought, by the help of God, to prepare for it. Yet, she concealed her impression from us, for fear of giving us pain. When she disclosed her mind to me, I found that she had already advanced far in the Christian life. She lost every fear of death, and her hopes became brighter and brighter. "She was waiting," she said, "for the joyful hour, when her Saviour would call her to His blessed arms." Her natural reserve and timidity were thrown off. 'There was a purity of thought and a propriety of language, that indicated that we had never sufficiently appreciated the powers of her mind. Her aunt Maria likened it to inspiration. While still on earth she seemed to partake of the angelic character. I have never witnessed in $\mathrm{my}$ long ministry so triumphant a death.

We are, as you may suppose, worn with watching and sorrow, and will, therefore, linger for a week at "Blue Sulphur" for rest.

Think not that grief has unmanned me. I trust in God, and I will not repine. My energies will soon be restored, and I shall seek to perform the manifold duties that are yet enjoined upon me.

The departed had said to Dr. Burke, "Promise not to give me anodynes to deaden pain; I would far rather bear the greatest suffering, than to have my intellect clouded in the smallest degree;" and to lier Father, "Remember, bury me here; do not take my body over these rough, steep mountains, it is unnecessary trouble and expense. I can rest here just 
as well-and when my Lord comes, He will know where to find me; and I shall hear and know His voice, and rise to meet Him."

To His DAUGHTER JANE:

Red Sulpher Springs, September 10th, 1847.

My dear beloved Daughter: My letters addressed to Haskell and Wm., (his son) detailed to you the peaceful and triumphant close of our dear Julia's life. The mails are very irregular, still I hope they came to hand in due time.

Our beloved Julia was interred in the Cemetery at this place yesterday, at 2 P. M. Several Carolinians, I perceived, had found a resting place near the spot. The funeral services were performed and an address delivered by a Presbyterian Clergyman, Pev. Mr. Cunningham. Nearly all the visitors at the Springs were present.

I have had the body enclosed in a double case, as we may, in the future, deem it best to remove it. I have just returned from paying my last sad visit to the spot where our beloved Julia rests; the Cemetery is two miles from the Springs; but I felt that, in ali human probability, I should never be here again. It is now half past 5 o'clock A. M., and I devote the few moments left me before we begin our homeward journey, in writing to my dear, devoted and much loved daughter.

My duty to the departed has now been performed, as far as I was able; and I will try to give my remaining strength and energies to those who are still left to me, and to the other manifold duties of my life.

The regular line of stages has been discontinued, and we find that it will only be in our power to go to 
the Blue Sulpher. There we shall be able to find retirement. Your aunt and L., both need to recruit and gain strength for our fatiguing homeward journey over the mountains; we will return by the way of the White Sulpher, through Staunton and Charlotteville to Richmond. We may not be with you sooner than two or three weeks hence. I must. nurse up my poor sufferers. In the meantime, do not make yourselves uneasy about them. They are better this morning, and are packing up for the journey. I have just inquired and find that they passed a comfortable night. Dr. Burke, our very kind physician, goes with us, and I trust that the accounts you will receive of our further journey may be encouraging. I would not have my children to mourn over-much for the happy dead.

Not until our Julia's last days on earth, did I learn her deep thoughts on religious subjects, and her clear views of the plan of salvation. I had watched over Julia with deep concern, and fervently I had prayed for His spiritual peace to comfort her. When the end came, I rejoiced over her unshaken faith and trust in the merits of her Saviour. Her perfect submission, and her exalted hopes, exceeded by far, anything I had ever witnessed. The parting scenes-the invoking of blessings-the beauty of her countenance-the brightness of her eye, and the thrilling tones of her voice, were overpowering. Dr. Burke, says, "sublime, angelic."

I pray God to instruct, to support and to guide my house. I do not stand in need of human sympathy. God has abundantly supported me.

Write, my beloved children-write cheerfully to your aunt and sister. Put the best face upon all relating to our home, and say everything that you can, to wake them up to hope and cheerfulness. God bless you all. 
To W. G. R-Y, M. D.:

Blue Sulphur Springs, Sept. 11th.

We left the Red Sulphur Springs yesterday morning and arrived here in the evening, (a distance of about thirty-four miles). 'The travelling and change of location has operated favorably upon us allworn as we were by watching and sorrow.

We expect to remain ten days here and then go directly home.

You have been informed of our recent heavy affliction, and of the extraordinary evidences that our dear Julia gave of her trust in God-and her assurance of heaven. She left messages for you, (her physician). "When you go home, father," she said, "Send for my Doctor, in your study, and give these messages, as coming from one who has only a few days to live. Return my thanks to him for his kind and unwearied attendance upon me. Tell him, had it been the will of God that I should recover, his skill would have saved me; but $\mathrm{He}$, who is the All-wise, has willed that I should die early. Perhaps, He foresaw that if I lived, I should be worldly and forget my duty to Him. Instead of life, He has given me a joy in my heart that I would not exchange for the pleasures and riches of ten thousand worlds.

"Tell him to forgive me, if I have misunderstood him; but it struck me, either from his words or his manner, that he was skeptical in religion, and expected to merit heaven by leading a moral life. I, a sinner, plucked as it were a brand from the burning, want to tell him, that I never found peace, until I cast behind me my own righteousness, and by repentance, prayer and faith, rested alone on the merits of my Saviour. I was always a believer from education; but never felt the power of religion, till 
I became as nothing, and my Saviour, my all in all. Give him and his my love and farewell, and say that I fondly hope and pray, that in heaven we may be united in one family.

I have endeavored to use her exact words; but the impressive manner, the countenance beaming with intelligence, faith and hope, and the tones of her soft voice-these I cannot convey - I have no words that would give you an idea of the scene.

I have been greatly surprised at my own want of penetration, in not discovering 'before, Julia's powers of mind. I knew that she was a constant reader; my library gave evidence that she selected books that I supposed above her comprehension, and not adapted to the taste of one so young. But she loved to be alone, and she seems to have had a world of thought within herself, into which even her father and sisters were not permitted to enter. A reserve hung over her, from which I could not wean her. When she found, however, that she had only a few days to live, she unburdened her whole heart to me, and I felt as if in the presence of a superior being. She permitted friends to visit her, and cheerfully conversed with all. Dr. Burke pronounced her the most intelligent and spiritual being, that he had ever met with. There was no undue enthusiasm about her, and her countenance, words and manner, were singularly in unison. It seemed as though she possessed a premonition of her appointed time; "Father," she said, "Sunday is for the Holy Communion, Monday, to dictate messages to family and friends, and Tuesday, to die;" and thus it was.

She had desired to leave the worid on the wings of her father's prayers, and in the attitude of prayer her spirit ascended to her God. 
Dr. Bachman decided, that in accordance with his daughter's directions, the precious dust should not be removed.

A simple slab of white Italian marble marks the spot.

$$
\begin{aligned}
& \text { Sacred to the Memory } \\
& \text { of } \\
& \text { JULIA M. BACHMAN, }
\end{aligned}
$$

daughter of the Rev. John and Harriet Bachman, of Charleston, S. C.,

who died at the Red Sulphur Springs,

September Sth, 1847 - aged 21 years 11 months. Young, lovely, and beloved, she was early called away - far from her home and her many dear and valued friends;

but faith and Christian hope, sustained and supported her through the dark valley and shadow of death;

and, to the few loved ones, who were permitted to linger near her at the parting hour, her calm and triumphant death seemed but a translation from earth to heaven.

"Weep not for her! she died in early youth

Ere hope had lost its rich romantic hues, When human bosoms seemed the home of truth, And earth still gleamed with beauty's radiant dews. Her Summer prime waned not to days that freeze, Her wine of life was run not to the lees; Weep not for her!"

The letter given below, dated twelve years later, shows that the pathetic love between the Pastor of St. John's and his beautiful daughter, was still remembered in the valley of Virginia. It was written 
by a Minister (Episcopal), of South Carolina, who, at that time, was not personally acquainted with Dr. Bachman. A bunch of evergreens and wild flowers accompanied the letter-the bright Golden Rod was scarcely faded, though the busy hands that had gathered the memento, were already at rest under the sod.

\section{October 3rd, 1859.}

Rev. and dear Sir-During our visit to the Virginia Springs, Mrs. E., myself, and our little boy visited the grave of your beloved daughter in the cemetery near the Red Sulphur Springs; the spot was kindly pointed out to us by Mrs. D. We cut the evergreens from a tree standing at the East end of the grave, in the space between it and the monument over Gov. Alston's remains. The flowers were gathered from the grave itself. Knowing full well the strength and tenderness of parental affection, it has afforded us sincere pleasure to gather and present these faded mementoes of one, who though long since departed, yet, doubtless, remains fresh and green in your memory. Accept them as the offering of Christian regard.

This incident is now, to us, invested with thrilling interest. The little hands and feet, mind and lips, so busy on this day, (three weeks since), in the work of affection, have all been stilled and hushed in silence; and all that was mortal of our dear boy, rest too, in a distant grave. A sudden and unexpected attack brought deep sorrow to our hearts, as it tore him away from us. Yet we mourn not, as those without hope. A merciful God has early translated him to His garden above, where his leaf will never fade or wither; his bright and joyous life has been exchanged for one brighter still, 
and still more glorious in the kingdom of our Redeemer.

I am sure that we need not ask for your sympathy, nor for your remembrance at a throne of Grace.

Being no stranger to your character and services in our Master's cause, I am confident that you will not deem it a liberty when I subscribe myself, very respectfully and sincerely,

Your Brother in the Ministry,

Stephen Elifott.

Thirty-seven years later (1884), John Haskell was, as he expressed it, " passing out of love's clear sight to join the larger family on the other side." He had received the Holy Eucharist, and felt that it was his last Communion on earth-with his grandfather's child-like faith, he whispered: "I shall be the first to see Aunt Julia."

If the appointed biographer desired that this Chapter in his grandfather's life should be written in full, it was because the letters that detailed the brief life and triumphant death of his young kinswoman stirred his inmost soul.

I think that he might have closed this Chapter in his Grandfather's appealing words :

"Oh my children, will you not profit by this lesson?" 


\section{CHAPTER XVI.}

\section{Professor and Students.}

DEPRESSION OF SPIRITS-REVIVAL OF HOPE-NARROW ESCAPH FROM LOSS OF EYESIGHT-LETTERS TO VICTOR AUNUBON WHILE PUBLISHING QUADRUPEDS OF NORTH AMERICA-AGASSI\%-ATteNis A MEeting OF GeNeral SYNOD, CONVENED AT NEW YORK-VISITS AUDUBON-LETTER FROM HON. MITCHELL KING-ELECTED TO CHAIR OF NATURAL HISTORY IN CIIARLESTON COLLEGE-ANECDOTES.

WE resume our narrative, October, 1847. The devoted physician, Dr. Burke, hastened the departure of Dr. Bachman and his family from the "Red Sulphur." He accompanied them to the "Blue Sulphur," and, before leaving, commended them to the care and attention of the host and resi- dent physician.

A fortnight was spent here, during this time Dr. Bachman wrote to his friend Audubon: "My daughter L. is broken down; I do not like her symptoms, still I ascribe them to fatigue and excitement, and trust that change of scene and the quiet of her home may speedily restore her to health."

In the following letter to his son-in-law, we see his brave spirit shrinking appalled from the future - to his sad eyes graves are still yawning to receive his children: 


\section{Charleston, October 28th, 1847.}

My Dear Victor: I have had an anxious time since I left Richmond. There seemed to be no alleviation of my daughter $\mathrm{L}-$ 's distressing symptoms. After our return home she appeared to grow worse, rather than better. Dr. Horlbeck called in Dr. Geddings as consulting physician-for L. seemed to me sinking for lack of nourishment. One by one I have seen my children swept to the grave; we have not been out of mourning for years; and now I know not but that further and equally heavy trials await me. Say to my old friend Audubon, God bless him, and save him from the sorrows and trials that have desolated my path for years. * * *

But the light is breaking and the shadows fleeingaway. The following extracts from a letter show that the hopeful spirit was not crushed, but only over-shadowed for a moment.

To the SAme:

October 29th, 1847.

"I may be mistaken, but I think that there is a decided change for the better in L.'s condition. Although I have often before been disappointed, yet whenever there is the slightest improvement my spirits revive and, perhaps, I hope too much. Yet it may be fortunate for me in the end that it is thus. The rest of us are well.

My son Wilson is attending the lectures in the Medical College, and my boy William is doing well at the Charleston College. Affectionate remembrance and love to all, in which the whole family unite, especially to the dear little folk. 
To Victor G. ANd John W. Audubon:

OCTUBer 30th.

"I began this letter a few days ago, but laid it aside. I could not write about quadrupeds.

Before this reaches you, you will have heard details of our domestic trials; yet if I am not mistaken all the worst symptoms in L.'s case have lessened. But in this letter I intend to confine myself to the object I have in view, namely, to write about quadrupeds."

(Several pages of descriptions of the same follow.)

The letter closes thus:

"Now I have a proposition to make to you. Just come to Charleston with your brushes; bring with you the White Hare from the West, and all specimens about which you have a doubt; come to us during the latter week in November-we shall get the Deer. After some labor and trouble I have secured a Bear; the Otter and Mouse we will have too. But what is most important, we shall make arrangements for the completion of the work.

We could together do more in three weeks, than could otkerwise be accomplished in six months. If you would bring the little grandchildren, so much the better; but, at any rate, bring yourself. I have much to say to you-perhaps, your presence would divert my mind, and help to relieve me from a load of oppression that I am trying to shake off-that the windows of my chamber might once again be opened. If I could only again fix my mind intently on some one object of pursuit, I think that I would feel better. Come to us-I have a room for you, so has Desel, and Haskell has bought a plantation, only a morning's drive from Charleston. There are 
deer in abundance, and you can paint them on the spot.

On Monday I shall write you again, if I. grows no worse I have a world of things to say to you. $_{*}$

I am just packing up to go to a meeting of our Synod to be held in the Western part of Georgia : I expect to leave Charleston in an hour, and be absent for nine days.

My mind has become gradually more and more relieved with regard to my daughter L. Her spirits, that were depressed by recent afflictions, have regained their elasticity. Dr. Horlbeck has sent her a pony, and she is able to ride out every day.

Now Master John, who writes such short and such very unsatisfactory letter's about quadrupeds, I will make a bargain with you. Come on during the winter, or if you cannot, write me more fully. Be a good boy and confess that for a man that can hold a pen, you are a most backward correspondent, then I shall exchange visits with you. I shall come to you in May and bring my daughters J. and L. with me, and leave them with you awhile, to hear you and Victor grumble about that eye-sore of a railroad, and to enjoy your good company, and your fish and shrimps; and for a week, I can sit down with you and we can arrange the plates for the quadrupeds $* * *$ There is perplexity enough-the writing part, I do not mind over much, but the specimens are the need. We cannot complete the work as we should, without them * * * I have received the specimens from Lieut. Albert. The large Hare is a good specimen and will help me much-but is the only good one in the lot. John, you draw and paint well. I recognized your Hare from a shabby specimen in the Zoölogical Museum. * * * The hour is isere, and I must start, I shall write on my return. 
To Victor Audubon.

\section{Charleston, December 13th, 1847.}

My dear Victor- "I have been unable to write to you for ten days. I had returned from the meeting of the Synod in Georgia, and had but two days at home, when a sad accident befell me, which, but for God's providence, might have rendered me for the rest of my days like Milton, blind and sad.

I had prepared a mixture of gunpowder, sulphur and lard to anoint a mangy dog, and gave it to Sam, our little servant to carry to the yard. I was intently engaged in writing, seated by the fire with my feet on the fender. In his wisdom, Sam supposed that the lard should be melted, and he clapped it on the fire, about eighteen inches from my nosean explosion took place something like that of a cannon-it was nearly half a pound of powder. I was knocked over-saved twenty-five cents in haircutting, lost my eye lashes and eyelids, and was laid on my back for ten days, with grated Irish potato poultices as a remedy. Nothing but my spectacles, (bless them), saved my eyes from total blindness. I have now a new skin from forehead to chin. Yesterday I left the dark room, and looked again upon the light of heaven, and my eyes are so much better to-day, that I have been able to show you the scratch of my pen." * * * *

December 18th. This should have been sent to you, but I was compelled once more to remain in a dark room. I was there for five days. I am now quite better, (save my eyelashes and eyebrows.) I shall preach to-morrow, I hope; I see as well as ever to-day, only I cannot bear a glare of light. This is Saturday morning, and I am preparing for Sunday. I have several extra duties at Church-a Confirmation, and Communion. 
December 24th.

There has been some fatality attending our letters, but, by repetitions and cross-questioning, all will come well at last.

During the leisure of the last few days, I have been engaged in carefully examining the plates up to one hundred and twenty. My favorable opinion with regard to the execution of the drawings and lithograph, remain unchanged. John now figures quadrupeds, as well as his father ever drew birds in his palmiest days. I am surprised and delighted with the very superb figures he has made. What would I not give for some of his notes (for he has a discriminating eye and is an excellent judge of character). It is a pity that one who can use his brush so well, should be dilatory in using his pen. Tell him I want him to write out his opinion of the species he has figured in Europe.

I am working for your book with great pleasure now. I take as great an interest in your fame and welfare, as when our Maria and Eliza were by your side. For some time past my trials nearly overpowered my mental energies. I feel my sorrows still, though they are less intense. All absorbing occupation helps me. Although I often think deeply and sorrowfully of the past, I am not in the habit of speaking of private griefs, and shall not again trouble my friends with this subject.

We have received your Christmas gifts, and shall feast on them soon. Accept our thanks. (An English pudding, etc).

December 31st.

I have just returned from Haskell's plantation; the weather was rainy, cold and blustering; I am wet and chilly, and I fear, will not be in the most placid humor in the world, and would prefer, there- 
fore, to postpone my letter for a day; but as Maria is sending a box to your mother, I must write a few lines, at least.

I send two mice. John, I find, can make a good deal out of almost nothing-he will do something with these. I thank him much for his notes, they will help famously; but I must get more out of him.

I am hard at work among the quadrupeds; you could not have sent me a more perplexing list of questions, than those I am required to answer. But I am glad that you have done so, it has compelled me to look over your old letters for a year past, and I have been able this rainy day to overhaul most. thoroughly the Hares. * *

On to-morrow, I am to have a long conversation with Agassiz in my study, and I shall write you what he says in full. I find Agassiz's opinion, which I prize more than any man's in America, most favorable to our letter-press and engravings, (Quadrupeds of N. A.) He says that it has not its equal in Europe, in this department. I know that he is sincere, for he is candid; but alas, alas, we are sadly in want of material. I am ready to cesume my work-it is a hard job; but I do it with very great pleasure.

We find during this year (1847), few letters from Bachman to Audubon, and none in the hand-writing of the latter. 'The panacea, perfect rest, prescribed by physicians, restored Audubon apparently to physical health, but the noble intellect remained partially obscured.

The friends had undertaken with enthusiasm, the joint publication of "The Quadrupeds of North 
America." A new and difficult field in Natural History lay open before them, demanding close investigation and patient experiment. But such toil was congenial to these ardent students of the Book of Nature; and their labors were lightened by companionship and sympathy. Whose eye but the Omniscient could see the gathering cloud, and who dreamed that before the last number of the first volume was published, the work-day of life for the gifted Audubon would be ended. But so it was.

The plates for the "Quadrupeds" were provided for ; John Audubon painted the animals and Victor the landscapes and other backgrounds, and Miss Martin continued to contribute Southern flowers, etc.; but without Audubon, Bachman stood alone in the letter-press, for the sons of Audubon were artists, and not naturalists. Under these circumstances, Dr. Bachman hailed with delight the arrival in Charleston of Professor Louis Agassiz, the distinguished Naturalist, at that time Professor of Natural History in Harvard College.

Bachman had followed with deep interest, the laborious investigations of Agassiz among the lower animals, and was under the impression that he had alsn studied the Mammalia with equal care. Agassiz, with his accustomed truthfulness and candor, undeceived him. It was a great disappointment to him, for in the publication of the Quadrupeds he sorely folt the need of consultation with other scientists. 
To Victor and John Audubon:

JANUARY 6th, 1848 .

"Your letters are two weeks on the passage, and mine, if they reach you at all, travel as slowly. Last week I wrote you two full sheets about animals, names, etc. It cost me two days' work; has it been received? Write forthwith.

Alas! Agassiz cannot help me; he knows nothing about Quadrupeds, scarcely one of our animals, and not those of his own country.

The late T. O. Summer, D. D. (of the Methodist Church), Dean of the Theological Faculty of Vanderbilt University, Tennessee, has left a manuscript, entitled "Personal Recollections of Dr. Bachman."

He writes: "When the Scientific Association met in Charleston, Dr. Bachman had the distinguished Agassiz frequently for a guest. One day, pointing to the skin of a fox, the Doctor said, playfully, 'Agassiz, you know that fellow?' 'No,' said A gassiz. 'Why,' exclaimed the Doctor, 'That is the fox of your own native forests.' Agassiz remarked: 'I know very little of mammals.' He had devoted himself chiefly to molluses and fishes. The Doctor told me this to show how little value was the dictum of Agassiz in regard to the polygenism, which was, at that time, so vehemently asserted by many scientists. 'They wished to get Agassiz on their side, but he never went any farther than to advance his untenable hypothesis of eight Zoölogical centres, comprising as many autochthonous races, though not species, of men."

On the 14th of May, 1848, the General Synod of the Lutheran Church convened in New York City. 
Dr. Bachman was a delegate to that body. In the latter part of April, he left Charleston in a sailing vessel bound to New York, accompanied by his daughters, Jane and Lynch. He writes to his family in Charleston, from the Audubon home:

\section{Minnie's Land, May 11th, 1848.}

The girls say that they have heard "the music of the minstrel's nose." As I sit on an arm chair, with my feet on the hot fender this chilly evening, I am half inclined to think that they were, in part; right; for I feel a little drowsy just now-I had better try to shake off lethargy by writing a few lines home. But how shall I collect my thoughts amid the din and confusion that prevail around me; yet I like to see these happy faces and hear their merry laugh.

I found all well here, as far as health is concerned. Mrs. Audubon is straight as an arrow and in fine health, but sadly worried. John has just come in from feeding his dogs. Audubon has heard his little song sung in French, and has gone to bed. Alas, my poor friend Audubon! the outlines of his countenance and his form are there, but his noble mind is all in ruins. I have often, in sadness, contemplated in ruin a home that, in other years, I have seen in order and beauty, but the ruins of a mind once bright and full of imagination, how much more inexpressibly melancholy and gloomy. But why dweli upon these? I turn away from the subject with a feeling of indescribable sadness. $* * *$

The weather has been rainy for the past four days, but this afternoon it was clear, but quite cold. The Spring here is further advanced than I expected to find it, the fruit trees are in full bloom, and the grass of a dark green. The woods and the grounds 
are full of the melody of singing birds. There are not less than twenty wood-robins, whose notes can be heard in this vicinity. A red-breast has built a nest in the cherry-tree, near the piazza; the pee-wee is building close by, and the robins have found a home here. I, too, would willingly linger, but I must be on the wing. Day after to-morrow I expect to take the girls with me to New York, during the meeting of Synod. I want them to see a little of this great city.

I am working away among the Quadrupeds; and, if I had nothing else to do, could spend a month here with great satisfaction; but as it is, time is passing, and I must soon turn my face homewards. I do not yet know if the girls will decide to return with me.

Mrs. Audubon is going into the city maid-hunting, to-morrow morning, and I shall send this letter by her to be posted.

Tell Master John Bachman (Haskell), that these little folk, of all sizes, sit and play all day in $\mathrm{my}$ room, and do not touch the specimens; if my little restless, roaring, tearing dog was here, he would make the fur fly, as well as the heads and the tails. All send love to Aunt Maria, and to the girls and boys.

$$
\text { Your affectionate father, J. B. }
$$

The two sons of Audubon were both united in marriage a second time; John, to Miss Caroline Hall, of England; and Victor, to Miss Georgiana Mallory, of New York.

The first born of these marriages were daughters. John Audubon's daughter, at baptism, was named, Maria R.; and Victor's, Mary Eliza. The heart of the 
Pastor of St. John's was inexpressibly touched by this unselfish tribute to the memory of his idolized daughters. The wives of his sons-in-law were to him, from that hour, as his own beloved daughtersin-law, and their children as his grandchildren.

\section{New York City, May 16th, 1848.}

"I yesterday received my first letter from home, and we were much gratified at its contents. I am glad that A- is safe and well; may the little girl live to marry a man, who will be fit to become the future President of the United States. Love and congratulations to $H$. and to A., and kiss this precious lump of mortality for us all.

I was somewhat surprised and a little amused at your fears with regard to the hail-storm. It must have been infinitely more severe on shore than on sea. The largest hail I saw was not much larger than a musket ball. There was just a tolerable squall. We had a very prudent and careful Captain. The vessel was all in order when the squall struck us; there was, in reality, nothing to alarm an old sailor like myself, who has seen storms compared to which the present was like a pigmy to a giant. I think that L. was a little frightened, but the fright soon passed off-danger there was none. The voyage on the whole was a very pleasant one; we were saved from the bustle and jarring of a steamer, and our pockets were fuller by thirty dollars.

I have brought the girls to New York; but I fear they will see little of the city. They are timid; I am busy at Synod and have not half an hour to go out with them. We are staying at E-'s; his son will take J. and L. in their carriage and show them the city and the lions this afternoon. Later in the evening they propose to return to Minnie's Land 
with Victor. I somewhat regret it, as I want them to see a little more of this great and wicked city.

New York appears to me like another London in miniature. Broadway contains at all hours of the day a moving mass of human beings. If you are on the sidewalks, you are elbowed and jostled; if you cross the street you are in danger that the wheels of an omnibus may crush your foot, if not your neck. If you stand still you may have your pockets picked, and if you run the cry of "stop thief" will follow you.

Yet, after all, New York is not a bad place. Though it is busy and bustling, people are polite and well-dressed, and the fashions are not very unlike those in Charleston. I think that more wealthy young men attend to business here than with us. Of abolition I hear not a word. New York seems prospering in a very high degree, and is destined to become one of the largest cities in the world. As I looked at the many pretty women in Broadway, I thought that no love-sick swain had any reason to hang himself if jilted, inasmuch as the vacuum in his heart might so easily be filled up with one of the crowd that always seem ready to fill up every vacant gap.

I am constantly interrupted while writing, and feel that my mind is like our old friend S_'s, " all scattered about." * *

* *

I think the Synod will not adjourn until the end of this week. It is a large body, and every one wishes to make a speech. I am chairman in an ugly business, intrusted to me by a Western Synoda poor fellow is in trouble, and I fear that things are against him.

I shall probably, return home in a steamer, and shall certainly be with you before Sunday, 28th of May. God bless you all. 
Leaving his daughters in the hospitable home of Audubon, he returned to fill his pulpit at the time appointed.

'To his Daunhter Jane:

Charleston, Aug. 27th, '48.

It was a delightful day to me, when your letter. dated the 18th, was handed to me. I have read it the second time; it is characterized by strong good sense, and there is such a propriety in your thoughts and expressions that I could not fail to be proud of my daughter. Then I felt convinced that your eyes were better-for you kept accurately to the blue. lines on the paper. May we soon have reason to rejoice in a permanent cure of your eyes.

I too, suffer, at present, from my eyes; I cannot read much and scarcely venture to write; I suppose I have taken off my spectacles a dozen times since I began this letter. I may have to give up reading and writing altogether, which would be to me a very great deprivation, but I am prepared to do so without one murmur or complaint. Come daughter Jane, let us make a bet of a quart of ice-cream, and see which of us can first find a needle in a haystack. *

Well, daughter L__- what shall I say to you; are you home-sick, child? No! everything to you is yet the color of the rose. Give my love and a kiss to the Audubon ladies; the old girl is a diamond, the others are gold.

Come here my granddaughters-my Lucy and my dumpty Harriet, let me kiss you and tumble you about. I hear that you are obedient and affectionate to your grandparents and parents, and that you improve in music and other studies. You. must learn to play, chat and read for grand-pa 
Bachman, to cheer him when he is old, and the grasshopper has become a burden.

Now, dear Jane, I must stop-the others know more gossip, and their letters will be more interesting than mine. I only write to show you that you are in all my thoughts, and in my prayers. I am living only for my duty to God, and for my children's happiness-when all goes well with them my mind is at peace.

May God watch over my dear daughters, and may we soon meet again in health and with grateful hearts.

Tell L. to guess which of the daughters will receive the next letter from,

Your affectionate father, J. BACHMAx.

To V. G. Audubon :

Charleston, October 20th, 1848 .

My dear Victor-In regard to plate No. 30, I cannot give a name until I am certain that no one has named it before me.

No. 1. Pouched Rat from Georgia.

This animal was described in the New York Medical Repositary, January 1821-Get and copy the description for me. I will sond you by to-morrow's steamer a living one. I have had it all Summer: it is a gentle and most pleasant companion of mine, eating from my hand, and looking at and seeming to talk with me. If John cannot figure the one he has already, he must try his hand on this, but don't kill my pet, if you can avoid it. I take it out by the tail and hold it in my hand, and it has never attempted to bite me. You perceive it has a naked tail. If Mitchell's animal has a short naked tail, then we must give this fellow a new name. * * *

You have, I think, specimens of both the Southern 
Pouched Rats-the Florida and Georgia species; they greatly resemble each other-so do all the species."

A list of descriptions of plates follow.

He continues:

"Last evening I used my eyes by candle-light for the first time. Dr. Frost has me in hand * * * I at least fancy that my eyes are a shade better, but I am obliged to be bat-like and avoid the light.

Soon I shall go to work again on the quadrupeds. The work was begun before either your father or myself were quite ready. You see how I am situated, and you must be patient. I have imperative duties. I will aid you all that I can, but I cannot consent to endanger my eye-sight, and when I begin to write I know that I cannot stop. Love to all.

In the Spring of 1848 , Dr. Bachman received a letter from the Chairman of the Trustees of Charleston College, (Hon. Mitchell King), stating that Natural History had been added to the curriculum of the College, and that he had been unanimously elected Professor of Natural History.

After consultation with the Vestry of his Church, he accepted the position.

\section{From Hon. Mitchell King.}

Charleston, April 14th, 1848.

We had the strongest confidence that you would accept the tendered chair in our College, and that your respected vestry would approve and encourage the acceptance; yet, I assure you, I am delighted with your note just received, which tells me that 
confidence is now certainty; and while I would venture to congratulate you on the extended field on which you may now spread the love of your favorite science, I would.much more deeply congratulate our cherished institution, and the young gentlemen under its care, for the invaluable addition which you will bring to the curriculum of their instruction. To you it is a matter of secondary consideration, but to our institution, and to them, it is a matter of the very highest importance. Most earnestly do I trust, my dear Doctor, that you may find it a source of enjoyment to you, and of still increasing usefulness and reputation.

I am sure that it will advance the interests and the standing of our College, to have your name associated with it in the department of your choice, and we shall therefore avail ourselves of your kind permission to announce it.

With sincerest respect and regard.

Very faithfully yours,

M. K.

The duties connected with the Chair of Natural History were congenial to the Pastor of St. John's, and involved very little labor on his part.

He retained the Professorial Chair for three years, when pressing duties connected with his Ministerial office called for his resignation.

As he stood with his boys around him, the fire and glow of his youth was rekindled and communicated to his students. They sought his company in their vacations, planning with their parents to induco him to spend days with them in the country, or at the sea-shore. 
They were his guides into the forests. Here a mole burrowing, a toad buried alive, or the gyrations of an insect-a wild flower-or even a blade of grass, furnished varied subjects for instruction and entertainment.

They showed him the nests with young birds, that they had discovered, and he taught them to distinguish the bird by its note-for, to his practised ear, the note of every Southern bird was as the voice of a friend. When in Europe, he is said to have made a wager (figuratively) with an English scientist, that in a week he could become familiar with every bird he met with, and tell its name by its note-and he did it.

He knew, too, the names of all the finny inhabitants of the salt and fresh waters in the neighborhood of Charleston.

He was a successful angler, though he would often say, that to wait hours for a bite, was too lazy a sport for him. Yet, when the fishermen at the seaside would draw in their net, he was seen watching for the haul in a state of expectancy and excitement, that would have delighted old Isaac Walton.

His boys drew from him all his best fish stories, and took a lively interest in every incident of a deer hunt. Many of these have been preserved.

\section{A Fish Story.}

Dr. Bachman was on a visit to the country home of a friend living near Charleston; his host was called away to the city, and he concluded to go fish- 
ing. The sky was over-clouded-a perfect day in the eyes of a fisherman. When he reached the stream and opened his basket, his line was there. but, by an annoying oversight, there was no hook attached to it. He returned to the house, thinking that he could easily find a hook. Alas! the search was vain. Here was a dilemma. He asked for a knitting-needle, bent and formed the wire into a clumsy but strong hook. Returning to the fishing ground, he threw out his line, and the bait was swallowed by a large Sheep's-head. As he drew him in and examined him, he could scarcely believe his own eyes-in the mouth of the Sheep's-head was a hookthe large fish must have broken the line of the angler who had previously endeavored to capture him.

With joy and care, he drew out the hook and substituted it for his own clumsy manufacture. With this newly-found hook he caught a large number of fish, and returned to the house to relate to the good house-wife his success, and to present the fruit of his morning's adventure.

The late Dr. T. O. Summers gives the following:

"The Doctor told me that he one day killed a giant-not a man, but a whale. It was in this wise: He had embarked off the Delaware in a vessel bound to Europe. While the crew were ashore, he saw the spouting of a whale within rifle shot. Having a rifle at hand, he shot at the monster, whose blood tinged the waters-that was all he saw. Shortly 
after, being in Paris, he saw in a newspaper that a whale had been washed ashore near the mouth of the Delaware, and on dissecting him it was found that a shot had penetrated his lungs. No one could solve the mystery. The Doctor solved it."

We find among the notes of his grandson, John Haskell, another reminiscence:

"On a certain deer hunt that took place on one of the plantations near Charleston (probably Dr. Desel's, Goose Creek), my grandfather was put at one of the best stands, for the hunters knew that they could rely upon him. He maintained his reputation that day-he killed two deer and two turkeys. Covering the deer with leaves to eonceal them, he blew his horn, and when the party rode up pointed to the turkeys, and then, to their great surprise, uncovered the deer."

The old negroes, who lived on the plantations around Charleston, and were then the young men who assisted in bringing home the deer, etc., still preserve wonderful stories of Parson Bachman's "sure aim," and delight to tell how many turkeys, deer, etc., they carried home as the result of the same. 


\section{CHAPTER XVII.}

\section{$1848-1852$.}

\section{His Second Marriage.}

HeALTH FAILS-SOJOURN AT MADISON SPRINGS-VISIT FROM VICTOR AUDUBON-LETTER TO EDWARD HARRIS-(2UADREPEDS OF NORTH AMERICA-HIS PART IN THE WORK.

\section{To Victor G. Audubon :}

Charleston, Dec. 18th, 1848.

JEAR VICTOR: I am sure that you will be $\mathcal{U}$ glad to see a few lines written by my own hand, at daylight. It is just to say that the old fellow is alive, and only half blind. For three months I have been sadly off. If I only wrote or read for half an hour I was punished all night with sand in my eyes, and such an itching that I waked every half hour. I tried to abide by the Doctor's prescriptions; rested my eyes, and even used no notes in the pulpit or at college.

I go out of town, and leave cares behind me whenever I can-and am the better for it. I shall go to Columbia, Lexington, etc., to spend my vacation-week, and return to my duties on Saturday.

Now about the letter-press. At last, I think, I see my way clear; Maria has promised to be my amanuensis, and, on the second day of Jamuary, she will hold the pen for me. There is only one other person that could do this, and that is yourself; but I won't call on you unless the other plan fails. 
We are looking out for John, and shall be most glad to see him.

Send your bill for the work subscribed for by "Charleston Library Society."

Now I shall entrust you all with a secret. Your Aunt Maria has been weak enough to consent to take the old man, with all his infirmities of mind and eyes, for better and for worse, and thus lawfully become his nurse and scribe, on December 28th, so please demean yourself accordingly, and acknowledge with me that she is so amiable and good-tempered, that she will not scratch out the poor remnant of my eyes left to me.

With love to all and congratulations of the season, Affectionately yours,

J. B.

Fouyd on the Fly-teaf of an Old Book.

To Mrs. Bachman :

My Beloved Maria: The presentation of a Cookery book from a husband to his bride, does not, at first, appear to evidence much of that sensibility and romance, which such an occasion would seem to inspire. I, however, send you this little book, not to remind you either of your duty as a good housekeeper-for of that I have already had satisfactory experience, or of my appetite for luxuries-for this I ought not to encourage; but, as I once heard you remark that you would like to own this book, I send it as an evidence that I shall ever be disposed to devote myself to you, and to comply with your least wish.

December 28th, 1848.

John. BaChMAN. 
Victor Audubon to Mrs. Bachman:

New York, January 28th, 1849.

My Dear Aunt Maria: Your letter was received day before yesterday, and, I assure you, that it was read with no ordinary satisfaction. May you enjoy every blessing.

Now I feel assured of the completion of our hopes and wishes in regard to the letter-press of the "Quadrupeds." * * I hope that the task of completing the work will not prove too irksome to you and to our friend, your husband.

*

V. G. A.

On the second day of January, according to promise, Dr. Bachman and his wife, were to be found in the study, surrounded by stuffed specimens, papers and books, employing every leisure moment in the preparation of the Second Volume of "The Quadrupeds of North America." An author has said, "Time is fertile in deceptions, and never gives us the fourth as much leisure as he promises." It did not prove otherwise in this case.

One rule the Pastor of St. John's had laid down for himself, viz: Pastoral duties-what he called "the imperative duties," always first; scientific labors in the second place. Still, by early rising and systematic labor, the work on the "Quadrupeds" steadily went forward. Mrs. Bachman, under the direction of her husband, carefully took the measurements of the specimens. Besides, her artist eye was invaluable to him in deciding the exact shades of color.

When the. Spring came, however, and the March winds began to blow, we find him languid and 
spiritless, scarcely equal to his pastoral duties, and continuous literary work was out of the question. Woe to the man that stands alone under these circumstances! But Dr. Bachman did not stand alone; his faithful wife was at his side. With consummate tact she had the specimens removed, and carefully laid aside the papers. "You are only suffering from weakness of body," she said, "You must take a vacation, and as you grow stronger, your old love for the work will return." She quietly made the simple preparations necessary for the trip; at the same time his congregation urged upon him the necessity for the same, and took a lively interest in the efforts to secure a quiet retreat where he could recuperate his strength. Madison Springs, Georgia, proved a happy selection. The specimen books, etc., that had been laid aside, were brought out and packed in readiness for an early departure.

Dr. Hazelius had written from Lexington, "Come and see my fine vegetable garden. I want you to see the plants raised from the seeds you sent me. I am needing your advice about the Seminary, don't pass me by." We find in Mrs. Bachman's handwriting, a few dottings by the way.

Tuesday, June 12th, '49 : "Dr. B. and myself left Charleston for the Madison Springs."

Wednesday was spent pleasantly with Dr. Hazelius' family.

On the 19th we reached Madison Springs. The location is fine, and climate delightful. We are the only boarders and are comfortably accommodated." 
A large empty room which opened from their chamber was put at their disposal. A few wooden tables and chairs, were brought in, and specimens, papers, etc., were soon arranged in readiness for work, "when the old love for it came back." Perfect rest, aided by the healing waters, had an almost magical effect.

Rejoicingly he writes to Victor Audubon :

\section{Madison Springs, June 30th, '49.}

"I have very cheering news to give you. I have been here eleven days; the day after my arrival the giddiness in my head and other horrid symptoms that have distressed me for months, began to leave me. I sleep well, drink the water, and take a shower-bath daily. Best of all, I am able to work without suffering from my eyes.

I begun working four hours a day, now I can work for twelve. I shall lessen the hours, should I find my strength failing. This is my tenth working-day. I have finished seventeen articles, and arranged notes for another. I have used as many of your notes as I could. Maria copies carefully. She lops off to the right and the left with your notes and mine; she corrects, criticises, abuses, and praises us by turns. Your father's notes, copied from his journal, are valuable-they contain real information; some of the others are humbug and rigmarole; but you have done so well as to surprise us.

To-day, I wrote the life and doings of the Opossum; my article will occupy me for another day. Three days ago, I wrote the article on the Ermine; what you sent me lacked information, and I possessed it; in going over its history, I found and described a new Ermine-a small 
one with long ears; and hairs becoming white in Winter.

(A page or two of notes and descriptions follow); the letter closes thus:

"I hope that if nothing untoward happens, the Second Volume will be finished in a month, and the Third Volume next Winter.

I am in a quiet place for work, free from mosquitos, and free from two-legged idlers-that are worse. Maria will finish this letter."

Mrs. Bachman, to̊ the Same.

"I would have written to you, dear Victor, long" ago, but I had nothing agreeable to communicate; as, at home, Dr. Bachman's inability to apply himself to the work seemed to increase every day. This journey was a happy thought, as the change of air, relief from his many laborious home duties, and, perhaps, the water, have quite restored him. $\mathrm{He}$ seems to have recovered all the energies of his mind, and is steadily employed every day, without being much fatigued by it.

When at home, he devotes much time to his large congregation, particularly to those who are ill or in distress; and there are many other duties that leave. him but little time.

We came here about eleven days ago, and have found these Springs a delightful retreat from the bustle of the city. What would render it a dull place to most people, has given it a charm to us, viz: the absence of company-it is yet too early for visitors to resort here. In this calm and rural spot, surrounded by lofty trees, while the robins and other songsters enliven us with their music, Dr. Bachman has become a new man. Free from all the little cares that intruded upon his hours of study at home, 
he goes to his work, not as a task, but as a pleasing occupation of hours that would otherwise hang heavily on his hands.

$\mathrm{He}$ is every day cheered by the progress he is making, and I am trying to assist him when and where I can. Do not mind what he says about my criticisms, as I should never presume to undertake to do all that he jestingly gives me credit for. At any rate, dear Victor, my heart is cheered by being able to copy for the printer, \&c., to give you the good tidings that, if nothing interferes with our present plans, your mind may be at ease about the Second Volume. Some of the greatest difficulties connected with it have already been surmounted.

We intend to remain here until we are driven off by the fashionable crowd. My love to your mother and to all around you.

Your affectionate aunt,

M. B.

'The fashionable crowd did not make their appearance, and many of the visitors who arrived later, became greatly interested in the "Quadrupeds." All considerately refrained from intruding and interrupting him in the mornings. They were content to gather around him in the evenings-they asking and he answering questions connected with Natural History. He retired early, and rose at daybreak, with head cool and mind clear.

We find from Mrs Bachman's note-book that, during his vacation, Dr. Bachman preached every Sunday but one, either at the Springs, or at a village church. When his route had been marked out, a deputation, several times, met him at the station to secure his services. It was affirmed by some who 
were present, that they had never heard him preach with greater fervor or freedom.

From his Daughter Harriet (Mrs. W. E.

$$
\text { HASKELL.) }
$$

\section{Totness, July 18, 1849.}

"I hope to be in Charleston, with the children, to ineet you on your arrival.

My baby, with her winsome ways, is very sweet. Maria, her colored nurse, is to be a bride to-night. 'The washroom has been thoroughly prepared-the walls whitened and dressed with evergreens. Written invitations have been sent out a fortnight since, and all the servants have a most knowing look. I shall leave this interesting subject, and tell you of the exploits of your grandson, John Bachman (Haskell).

One Sunday afternoon he made his first appearance at Church. We took him to Grace Church, his half-sisters declaring that the stained glass would amuse him and keep him quiet. Alas! as soon as the responses began, he joined in, and, ere long, the spirit of fun possessed him. As I turned to check him he rose in his seat, snatched up his father's hat, cocked it on one side of his head, and imitating his voice, called out: "Ben, saddle my mare." Poor fellow, he was punished by not being allowed to go to church yesterday, and he seemed very much ashamed of himself.

You say, father, that my boy may live to be a great man-God grant that he may be a good one! My first-born, how my heart would bleed to find him guilty of any low or mean action." * * *

H. E. H. 
To Victor Audubon.

Charleston, August 24th, 1849.

We arrived at home, day before yesterday. The best news I can give you is that my health continues to improve; the next best news, that the Second Volume is almost finished. I have only to be sure of my Latin descriptions (I had left my Latin Dictionary at home.)

Maria and Haskell have a little copying to do, and then the book will be ready for the press.

J. B.

The gold-fever was then at its height at the North. Mr. John Audubon was the leader of an expedition to California, in 1849.

From Victor Audubon.

My brother will leave us in a few days for California, he will be absent, perhaps for eighteen months.

This journey is undertaken with the hope that he may be able to get gold. What may be the result, God only knows. John will be accompanied by Col. H. L. Webb, as military leader ; the party consists of about eighty picked men. One of Dr. Mayer's sons wished to go with John, but unluckily, his application came after the party was made up, so they could not take him.

I should like much to see you all, but now it will be impossible for me to go so far from home.

My dear old father is apparently comfortable, and enjoys his little notions; but requires constant care and attendance; the rest are well. Your granddaughters are growing finely, and are well educated; soon we shall call in a "maitre de danse," to polish 
them up and improve their understariding (a pun meant.)

I am just about to start for Washington, to get letters from the President for John and I will try and see the collection brought back by the exploring expedition, including the famous Black-tail Deer. I am in a great bustle, the office is full of Californians. * * * * * * ${ }^{*}$ V.G. A.

From various unlooked-for causes, the expedition proved a financial failure. Mr. John Audubon, however, drew many lovely views of California, that were afterwards lithographed, and he gained valuable information of the country.

To J. W. Audubon.

$$
\text { July 13th, } 1850 .
$$

Dear John-Hail all hail! You have come back alive and well, thank God! Now take courage. I believe you have brought back no gold, but you have brought to us yourself. You have found wife and children safe and well, so be thankful.

Don't fret, you have gained experience, and will have long yarns to spin. You have youth and health on your side, trust in God, and all will yet be well. You did your best; you exhibited bravery and humanity, and experience makes a man wiser and better.

We are all well. Our little John Bachman is a very interesting chap; he calls himself " $D r$. Bachman;" he is wilful and full of fun; he amuses me and vexes me by turns; yet, I confess that I do not feel quite satisfied if he is not sitting at table on his high chair at my side.

Love and congratulations to all. 
To V. G. Audubon.

Charieston, Sept. 1st.

I am at home again, have just returned from a trip to Graniteville.

I am well and ready to begin work, (Third Volume of Quadrupeds.)

I remember one day being on board of a ship just ready to sail. The sailors had been drinking, and the captain was about ready to use the rope's end. The lads half sobered at sight of "the cat-withits-nine-tails," exclaimed, "Captain, we are done cruising." I believe I can now say, "I am done cruising." I am ready, Victor, for work. * * * *

I have a world of things to say, but not now: as the ship is ready and my man is waiting.

$$
\text { J. B. }
$$

The Large Edition of the Quadrupeds, was published in 1849 and 1850. It contained the figures and descriptions of the Quadrupeds of the United. States, of part of Mexico, the British and Russian Possessions, and the Arctic Regions of North America.

In 1852 , a miniature copy was prepared and published with additions. His son-in-law, Victor Andubon, wrote that he was ready to come and relieve Mrs. Bachman of her labors as amanuensis, in connection with the additions to the "Smaller Work."

To Mr. Edward Harris, of Morristown, N. J. :

Charleston, March 13th, 1852.

My Dear Sir: Rejoice with me, the book is finished. I did not expect to have lived to complete it. But Victor Audubon came on, and I made him 
loold the pen, while I dictated with specimens and books before me, and we went on rapidly ; we worked hard, and now we are at the end of our labors. I have, at last, prevailed on them to give the Bats. At the end of the work, I intend to give a synopsis and scientific arrangement of all our American species, including the seals, whales, and porpoises. This will be included in the letter-press of the Third Volume.

Here I will venture to consult you in regard to the publication of additional plates of species, not figured in the Large Work. A very few small Arvicola and Shrews, we may not obtain, and they cannot be figured; but nearly all are within our reach. Some of the subscribers have bound up their plates, and there cannot be a sufficient number to make even the half of another Volume. I propose, as all these figures will be contained in the Small Work, that they should be inserted in the letter-press of the Large Work, so that the subscribers, by merely paying for the cost of the small plates, would have the work complete-what think you of this?

What think you of Victor's obtaining one hundred and twenty-nine subscribers in about three days, and I think that he will double the number next week; so, if the "Large Work" will not par, the "Small" one, and this is large enough, is sure to do it.

But I had almost forgotten the main object of writing to you.

Do you remember a small animal, a Spermophile, that resembles "Says' S. lateralis," that you brought to me. I took it for that animal, although Says' description did not exactly suit it. Since then, I have received Says' species, and on comparing them, I find that yours is a new species which I have named Spermophilus Harrisii. Now, as you have 
been flying to immortality on the wings of woodpeckers and other birds, you may be unwilling to submit to the slow process of riding thither on the back of a Marmot Squirrel. But you must endure it, as I was compelled to do, when a shabby fellow in the back country, who had never seen me, walked some miles to show me a dirty little urchin, with. out shoes and stockings, hat or clean face, whom he had named John Bachman. Now what do you know of the history of this little name-sake of yours? Where was it procured, and did it live in communities like the rest of its species? I see it has cheekpouches.

Mrs. Bachman and Victor join me in kind remembrances to you and to Mrs. Harris.

In March, Victor Audubon, previous to his return to New York, visited Savannah and Augusta, Ga.

In a sketch of Audubon's life, contained in a Northern journal, we read this sentence, in reference to "The Quadrupeds of North America" : "Dr. Bachman, of Charleston, helped in the compilation of this work."

We insert the following letter of introduction, which we find in Dr. Bachman's hand-writing; it tells us the part he took in the letter-press of "The Quadrupeds of North America." The inscription of the letter is wanting. It was written to a friend residing in Savannah, Ga.

Charleston, March 25th, 1852.

My Dear Sir: My son-in-law, Victor G. Audubon, is on a rapid visit to the South, and has a week or two to spare, which he is desirous of devoting to the 
obtaining of subscribers to the "American Quadrupeds." The Work (Miniature) will be complete in about thirty numbers, furnished monthly at $\$ 1.00$ per number.

The figures were made by the Audubons, and the descriptions and letter-press were prepared by myself.

I have no pecuniary interest in this work, as I have cheerfully given my own labors without any other reward than the hope of having contributed something toward the advancement of the cause of Natural History in our country. I am, however, anxious that the Audubons should, by a liberal subscription, receive some remuneration for the labors and heavy expenses incurred in getting up this work. Of the character of the work it does not become me to say much. I will only add that in my department is summed up the result of investigations pursued through a long life, and, I think, the figures have never been equalled in any publication either in Europe or America.

May I bespeak from you a little aid to my esteemed son-in-law, Mr. Audubon, in assisting him to procure subscribers. He is a stranger in your city; his time is limited, and his stay among you will necessarily be short.

By the aid of two friends here, he obtained two hundred and fifty subscribers in a few days. * * *

To Victor Auduron:

April 3rd, 1852.

The Bats send their best respects to you and say that they are nearly dissected, clean shirts on their backs and with a little extra brushing will be ready to see callers. We have had a strange visitor here. Two Seals made their appearance, one on the beach 
near the light-house and another at Beaufort. They were both taken. One I saw alive, but the man who seized him, gave him an unlucky blow, of which he subsequently died. I described him today, and regret exceedingly that you were not here to figure him. It is admirably set up at the college. I really wish we had a decent figure of this rare and most extraordinary animal. It has four legs, a tail thickly clothed with soft, glossy hair, and is as much a quadruped as the Otter. What folly it would have been not to have given the Seals-we might as well have omitted the Deer or the Bear.

I give now a report of the family. Immediately after you left, Haskell was taken quite sick-a man is an impatient patient - grumbling and fretting. Today he is down stairs, but looks as though he had been drawn through an auger hole.

C. has run a needle into her leg-it happened a week ago, and the doctor cannot reach it. She limps very much, but bears it cheerfully. At noon my son W-, leaves for his farm at Waulesa, Ga.

All join me in love to you, and all wish you abundant success in procuring subseribers at Marion. We are glad that you have done something in Savannah, and trust that Augusta and Columbia, will use you as well.

April 9th. Will you not return to New York by the way of Charleston and sail from here, take a manuscript volume in your pocket, and four hundred good and true names on your list.

The people have found out that I am 110 longer writing a Book, and they pounce on me morning, noon and night. I have arranged all the bats but one, and am writing descriptions of their habits, etc. I have nearly finished, in fact.

They bring me word that I have another grandchild. It is not christened yet (H. E. H.), but is a 


\section{The Study and Garden.}

little queen; she has sent me no message; but I presume I will soon have her love. * * *

My garden was finished this evening-it is nearly planted, and I have raised the whole about two feet. $* * * *$

Aunt Maria wishes me to stop, as she has much to say to you, and may criss-cross this letter. She is rather shackling. ***

\section{From Mrs. Bachman.}

Really, dear Victor, I do not intend to give you such an infliction as a long, "criss cross" letter, but only to add a few friendly words of chit chat, to let you know that, although I am rather shackling, I am still able to hold a pen and to make a pudding. I sincerely wish that you were here to share the latter with us. * * *

Dr. B. feels the loss of his companion, both in the study and in the garden, and will be very glad to show you the progress he has made in both departments since you left here.

The weather has been quite cool for some days, but is warmer now. The gardens are lovely. Mr. Chisolm's is beautiful. Hoping very soon to see you,

I am ever your affectionate friend and aunt,

M. Bachman.

The year previous, January 2nd, 1851, his daughter Lynch had been united in marriage to Robert T. Chisolm, Esq.

His son-in-law's taste for flowers, and well cultivated garden, were a source of great pleasure to Dr. Bachman. 
To Victor Audubon:

$$
\text { JULY, } 1852 .
$$

Your box arrived safely, and your two proofs came together. I return the latter; they were so carefully printed that there was not a word to correct.

$\mathrm{P}$ — has gone to the Virginia Springs. I have reason to believe that he is good pay, and that you may confidently depend on him. He makes a good deal of money by his law practice, but his wife is always pulling out the plug from the bung-hole.

I have not troubled my head much about politics; but I cannot swallow Scott. I go with South Carolina for Pierce; Taylor humbugged us so much that I mean to trust no more Seward Whigs.

My daughters, Harriet and Lynch, brought their babies to church yesterday, and they were baptized. All join me in love to your mother and to John, and to my little saddle-bridle racers. *** J. B. 


\section{CHAPTER XVIII.}

\section{2.}

LETTERS AND JOURNEYS.

LETTER ON EDUCATION OF DAUGHTERS-VISIT TO EUFAULA-A LETTER OF INVITATION TO THE NORTH-THE INVITATION ACCEPTED-TOUR OF THE GREAT LAKES-DR. JARED P. KIRTI.AND.

To Mrs. H., with REgard to the education of HER DAUGHTERS.

Charleston, January, 1852.

Dear Mrs. H.-The expression of your grateful feelings in your note of yesterday, for a very slight favor; but, more especially, the confidence you have reposed in me in asking, and kindly receiving my counsel, induce me to hope that this hastily written letter, may neither be unacceptable, nor altogether unprofitable to you, during your absence from your native State. (South Carolina.)

I feel as if I were familiarly conversing with a daughter, who, in all confidence is looking up to me for advice. I shall speak, without constraint, with you on a variety of topics-some of far less impor. tance than others.

If you have not an escort to the North, get some one who is acquainted with the Captain, to introduce you, and secure for you the proper attention; if my services are necessary, you may command them. From Philadelphia, I think, you can travel the whole way by rail, and reach Bethlehem the same 
day. Go to the hotel, which is I hear, comfortable, and send my letter, at once, to the Rev. Mr. Wolle.

For some months you may feel alone in Bethlehem, and, if I have not misinterpreted your feelings, you would welcome solitude and indulge in the luxury of grief. This is the course against which I would strive to guard you. Your life, your health, and the powers of your mind, are all essential for the mental training and happiness of your children.

In the days of youth and romance, I committed to memory in the original nearly the whole of " $\mathrm{Zim}$ mermann on Solitude," and fancied that to fly from the world, and to indulge in melancholy thoughts, would best promote virtue, and fit for heaven.

In more mature life, and as age was advancing, my theory was put to the test. One blow of affliction after another fell on my head, and my daughter's, with their mother-happy, because they were good. were removed from me. I then found that faith and trust in God, and the hope of a blessed resurrection, together with constant occupation and the faithful performance of duty, presented far higher claims to the Christian, and were far better calculated to assuage grief, than exclusion from the world and retirement from its duties.

While I am writing, the cold wind is driving snow flakes against my window, and the earth is already lightly covered with a white mantle; the sight recalls to my mind the rigorous Winters of the North, and almost disposes me to regret that you do not postpone your visit until Spring. At any rate, it suggests the necessity for warm clothing, heavy flannels and cloaks to suit your Southern constitution-but, in time, perhaps, you may even sound the praises of the fur-muff and tippet.

Soon, I hope, you will feel less lonely and more composed. 
You will find employment in attending to your and your daughters apparel; in studying economy, which is a virtue; in watching the improvement of your daughters in knowledge and virtue; in keeping up a correspondence with those who are interested in your welfare, and in reading interesting works. Associate with a few choice, intelligent and pious friends, above all, do not neglect self-examination, and intercourse with your Heavenly Father.

Should time still hang heavy on your hands, you have opportunities of acquiring a knowledge of the French and German language, (the latter, which is spoken in its purity at Bethlehem, is one of the richest languages in the world, in history, poetry, science and philosophy.) The acquisition of these and other languages, beguiled many a leisure hour of my life, and they were brought into requisition while travelling during eight months, without an interpreter, through nearly all the Kingdoms of Europe.

Thus, by constant occupation, I am sure you will so beguile the sorrows of a bruised heart, as to be able to discharge your duties, to look on the glorious heavens and the smiling earth, and feel that the Lord has not hid the light of His countenance from you. Nay, you may almost realize the dream of the poet's Elysium, (I quote from memory):

"Content, retirement, friendship, books, ease and alternate labor ;

Progressive virtue, and approving heaven."

In the moral and mental training of your daughters, I would advise that you become their companion and confidant. Do not keep them at a distance-let them feel that their mother is their best earthly friend. Make due allowance for their youth-the happy years. Try to smile with them 
when they are happy, and restrain them only in thoughts and actions that would lead to sin. Be a watchful, but not too anxious a mother. Do your duty, and then cheerfully and contentedly draw largely on the promises of your Heavenly Father, who will ever be the protector and guide of the widow and the fatherless.

In the education of your daughters, I do not object to the ornamental parts, but let the essentials of a solid English education, be particularly attended to: Reading, writing, arithmetic, grammar, and geography, with the use of maps and globes, history, book-keeping, etc.

Give them such a thorough education that in any reverse of circumstances, they may pursue honorable and useful employments; or, on the other hand, may discharge their duties as wives, mothers, and happy members of society.

Industry, intelligence, refinement, and pure religion, form, in my estimation, the characteristics of a true lady. I confess, that I have little patience with our fashionable, lazy young lady, who spends her nights at balls, and her days in lolling on the sofa with a novel, leaving her poor mother to toil, economize-and to speculate for her. Doll-babies are pretty play-things for children, but intelligent men will not resort to them-even as a pastime.

It would almost appear at first sight, as if I were venturing on forbidden ground, were I to advise you more particularly in regard to the practice of the duties of religion-on which all your earthly peace, and all your hopes for the future depend. I have always prayed to be preserved against bigotry and I have escaped I think, the charge of a desire to make proselytes. The true Christian, I hail as brother or sister, by what ever name he may be called. * * * You and I, are not very likely to dispute about forms 
of religion. I have said this much, that I may have your confidence. Be assured, that while you preserve the essentials of religion, your faith in God, your faith in the divinity and atonement of Christ, and the necessity of a new heart and life, I shall rejoice to know that you are a child of God, and an heir of heaven; and to feel that when we are gathered to our rest, we shall meet in a world where human error and imperfection shall be obliterated in the clear light of truth and immortality.

I did not think when I sat down to write you a few lines, that I should have drawn out this letter to such a length.

If I have been tedious, you must ascribe it to an old man's infirmities. You have solicited my prayers, you have them, and if the supplications of a poor, imperfect mortal, can avail, you and your children will be very good and very happy.

After a few months, you can judge if the school at Bethlehem presents those literary, moral, and religious advantages that you require; should it not prove satisfactory, it will not be difficult to select another; but, in this case, inform me, as I have friends at the North, and a general acquaintance with Northern Institutions.

When you arrive at Bethlehem, and have rested from your journey, I shall be muck. gratified to hear from you.

Believe me, very sincerely your friend, J. B.

A memento of this friendship is still preserved in Dr. Bachman's family.

Hair work was exquisitely wrought at Bethlehem, and Mrs. H., learned the art there. Obtaining, without Dr. Bachman's knowledge, a lock of the 
hair of every member of his family, she wove it into a wreath of flowers and leaves. The main-stem was formed of our mother's hair, and the "Heart's Ease" of our father's: the hair of the littie babies of the family-just long enough for pistils and stamens to the flowers, completed the family wreath.

The following sprightly letter was written on the occasion of a flying visit to Alabama to perform the marriage rite for his wife's nephew, M. D. S., Esqr., of Charleston :

To Mrs. Bacinman :

Eufaula, Ala., December, 1851.

In former years I had doubts if I should ever tread on the soil of Alabama; now, although I am only in one corner of it, I can say, "I am in Alabama." I do not, however, feel as if I had entered into a new region. The same sun is shining; the same long-leaved pines are growing, and the same sandy region presents itself as in Carolina (about the region of Columbia).

My last letter to you was from Macon, Georgia. Dr. S. came to take me out of the city to baptize two of his children. I visited some Indian mounds, and made many pleasant acquaintances.

In the evening $\mathrm{G}$. and his wife arrived ; later one party after another came in on different roads, disturbing our slumbers. We took breakfast before daylight, and, in a few hours, reached the terminus of the Railroad, Oglethorpe.

We soon ascertained that there was but one coach (and that would hold comfortably only four persons), and there were about a dozen passengers. We therefore commissioned the groom elect to be ready for a 
spring just as the cars stopped-to secure the seats. He accomplished the feat in fine style. Two strapping clerks went on the top-grumbling. We had eighty three miles to go with miserable horses. Presently it began to rain, and then to pour; the night was pitch dark; the streams swollen, and the hills high and slippery; we traveled scarcely more than three miles an hour, as, at every steep hill, we had to get out. To go over shoe tops was a small affair; I plunged in up to my knees. To rrown all, Mrs. G.'s sympathies compelled her to invite the strangers on the top into the coach. Mr. G. took her on his lap, and I had the two men on either side of me, soaked with rain, smashing me into a cocked hat. So we crawled along for twenty-two hours. A bridge had been washed away. I and the other gentlemen crossed on the sleepers, while Mrs. G. kept possession of the coach-delighted at the idea of an adventure. At length we reached Eufaula in safety; express riders had announced our coming. Mr. D., a wealthy planter, with a pretty young wife, gives, to-day, a dinner party and a great deer hunt, on my account, they tell me. They have learned here that I am a good shot, if I am good for nothing else. I have, however, declined to go, as I am very hoarse from exposure, and cannot speak above a whisper. I have had to disappoint these kind penple, who had made up their minds that I was to preach for them. Instead I became a listener, and heard three pretty good sermons during the dayone from a Baptist, the second from an Episcopalian, and the third from a Methodist. I should have omitted the night service, for I increased my coldthe lady doctors are dosing me with catnip tea, and nursing me up. I am better, and hope to be sufficiently well to tie a knot to-morrow evening, that neither the devil nor his angels can break. 
Now let me draw you a picture of your intended niece, though you know I am not good at sketching a lady, and always have to borrow your hand, even when I attempt to draw a monkey for Julia, (his little granddaughter).

Now I must not romance, but look at the creature as God made her. Stand up C. and show your good and bad points-always putting the best foot foremost. Her eyes are fine; she is rather under height and inclined to be a little stout. She dresses simply; is without pretension and makes no blue-stocking display; yet she has upset the bachelor, and produced a change in the inner and outer man. In her language and manner she is confiding; she seems domestic, industrious and remarkably amiable. I am sure that you will like her, as I do. The groom is at a miserable, uncomfortable public house-the best and the worst in the place. I tell him that he is an apprentice now ; but will soon have the honors and comforts of a master workman.

The bride's brother is a young lawyer, admirably suited to a new country opening a wide field for enterprise and adventure. $\mathrm{He}$ is a man of decided popular talent; a politician, stump-orator, an editor with fine business capacities, and withal a noble, generous, whole souled fellow. I like this young man very much.

There are such preparations for the wedding, as never before awaked the echoes of Eufaula. Fruits from Charleston-people coming fifty miles. The little world of Alabama is turned topsy turvey and the venison, the turkeys and the ducks, are to be offered up by hecatombs, on the altar of Hymen. I look at it all as a philosopher, enjoy it, and yet I shall be glad to be back in my quiet home.

I will leave here on Wednesday at two P. M., and travel all night in the coach, and if no accident. 
happens, shall reach Savamnah, Thursday night, take the steamer, and be at home Friday, at eleven A. M. There may be a disappointment-the coach sometimes breaks down, or a horse dies on the road, and then there is a stand-still for a day. Send for me on Friday. My love to all.

No disappointment occurred and Saturday found the Pastor in his study busily preparing for Sunday.

From Mrs. J. J. Audubon:

Minnie's LAND, March 31st, 1852.

"In my last letter I reminded you that as so:s and daughters were away from your home and your family consisted of only four, you might all come and spend a few months in this latitude; it would be of service to you all. Victor will. write to repeat my request. The visit would be to me a great pleasure, in which, I am sure, all at our home would participate.

You will find some changes in the outward, as well as inward circumstances around us. (Audubon is dead).

I have been planting various favorite shrubs and creepers over the resting place of your old friend; his cell is as quiet and solemn a resting place as the mind can conceive-and all, but the remembrance of his goodness, is gone forever.

The children send their love to grandfather and to all around you, in which I most hearlily unite.

Hoping that you will accede to our wishes.

I remain, yours affectionately,

Lucy Audubon.

We learn from the following letter, that the invitation was accepted. 
Dr. and Mrs. Bachman spent a few days with their friends at "Minnie's Land," N. Y., and then made a rapid tour of the "Great Western Lakes."

\section{From Mrs. Bachman to the Daughters at home:}

\section{Detroit, Michigan, June 18th, 1852.}

We are here nearly, or quite fifteen hundred miles from our home, which we only left three weeks ago. Ten days of that time we spent with the Audubous. at "Minnie's Land." We left our friends well on Monday last, at 7 A. M.

The cars on the Great Erie Railroad were comfortable, but crowded. We travelled on that day two hundred and eighty-three miles without stopping tor dinner; the route was interesting, and when we approached the last tributary waters of the Delaware River, the scenery was romantic in the extreme.

On we went at rapid speed, stopping only fifteen minutes for refreshment. I did not desire anything; but at 4 P. M., feeling exhausted, I fancied a cup of tea. When the announcement was made "five minutes for refreshments," your father in haste procured the tea. It was good; but so hot, that I realized the old adage "Many a slip 'twixt the cup and the lip." But even the small quantity I took refreshed me, and the little incident afforded us amusement.

We did not intend to stop at Dunkirk; but at Elmira discovered the loss of one of our trunks. We therefore concluded to wait for it at Dunkirk; the agent telegraphed to the different stations to have it sent up by an express train.

I cannot omit a pleasing incident, an act of hospitality from a Northern man, on whom we had not the slightest claim. Mr. Nottingham, (at the head of the R. R. department here) when your father 
asked him to recommend him to a public house, said "There is none I can recommend. If you do not object to a private house, I think that I can make you comfortable." He took us to his own house, where we were delightfully accommodated. We re. mained with these excellent people until the next day, (during the night our trunk arrived.) Of course we expected to pay for private board; but they would not listen to it. Mrs. N, insisting that our visit had afforded them great pleasure-surely we could not have been more hospitably entertained at the South.

We took the Steamer at Dunkirk for Detroit; the quiet day and night on the lake has refreshed us. Your father is full of life and spirits. He has a great desire to see a prairie and some of the natural productions of these Western lakes-I do like to see him enjoy himself! He fears that he will not have time to go farther West, as this is already the 18th of Jume, and we must be in New York by the end of the month, and he is obliged, too, to stop a day or two in Philadelphia.

We think of you constantly, and wish that you were with us; but as it could not be, it is cheering to hear from you that you are comfortable and happy at home. Travelling is very pleasant; but I think that we shall have even more gratification in telling you of all that we have found interesting, than in the actual enjoyment at the time.

Your father is as despairingly in search of a beattiful woman, as Japheth was of his father.

With love.

M. B.

This search for a beautiful woman, repeatedly alluded to in Dr. Bachman's letters, suggests the thought, that unconsciously the father's eye and 13 
heart were seeking a face that possessed the spiritual beauty of his daughter Julia.

When they reached the picturesque lake city, Cleveland, Ohio, Dr. Bachman found, to his surprise, Dr. Jared P. Kirtland awaiting his arrival. Dr. Kirtland, the eminent Professor, Physician, and man of varied acquirements, was well known by reputation to Dr. Bachman; but probably they had not met before. We remember Dr. Bachman's glowing description of the extensive orchards, with their fruitladen trees; the apiary with its hundreds of beehives, its busy workers and wealth of honey; the gay parterre and fragrant flowers-the senses were all captivated. The days glided away too swiftly in the society of their genial host, his delightful family, and a chosen circle of friends.

Years afterwards, when the tide of bloody war was surging over our land, Dr. Kirtland did not forget his Charleston friend. He wrote to the surgeons of the Northern Army who had been his students, requesting that, if in the chances of war, they should meet with Dr. Bachman in need, they would succor him for his sake. At the close of the War, Dr. Kirtland journeyed many miles out of his way to visit his friend in Charleston. They were faithful correspondents for many years (we regret that the letters have not been preserved). Dr. Kirtland outlived his friend, but not his friendship for him. This he graciously passed over to his family, and corresponded with one of the daughters until the close of his honorable life. 


\section{CHAPTER XIX.}

\section{IT ERA RY W O RK .}

OPRN-AIR PREPARATION FOR LITERARY WORK-DICTATION TO AMANUENSIS-PERSONAL RECOLLECTIONS OF DR. SUMMERS, AND OF DR. JOHN G. MORRIS-LITERARY CLUB-ADVENTURES OF A CLUB-NIGHT-UNITY OF TIIE HUMAN RACE.

WHEN Dr. Bachman arrived in Charleston, in 1815 , in very delicate health, by the direction of his physician, he spent much of his time on the United States Revenue Cutters then stationed off Charleston harbor. The invigorating saltair benefited him greatly; but unwilling to give up so much time to what seemed to him merely recreation, he formed the habit of taking with him his little blank book and noting down analogies, etc., suggested, often, by the natural objects that presented themselves. Thus he accomplished, in the open air, much of the preparatory work for his sermons and scientific publications. His hand was so steady that he could use his razor in shaving, or write on ship-board with almost as much comfort as when on land.

Rev. Dr. Summers, in his Personal Recollections of Dr. Bachman, writes :

"In preparing for the pulpit, the Doctor told me that he usually paced the floor for about two hours 
and a half dictating to his wife, who wrote his sermons for him: he became so accustomed to her writing, that he could read it better than his own."

When his faithful amanuensis lost the use of her right hand from a fall, a daughter's hand was used.

After dictating a sermon, he appeared perfectly fresh, and would sometimes dictate a second and shorter one for the afternoon. His habit was to select his text on Monday, to make his notes during the week, and to write out his sermon or sermons on Saturday. Sometimes the afternoon sermon was extemporaneous.

He dictated rapidly, seldom changing a word; but on Sunday morning, he would rise at day-break and go over his sermons, sometimes curtailing or adding to the same.

His delivery was clear and impressive, and his mind filled to overflowing with his subject-the amanuensis was often surprised at the happy illustrations interspersed, which were not contained in the written sermon.

The habit of dictating we trace from 1827, when the nerves of his eyes were affected by the fever contracted on the Western Lakes-which so nearly proved fatal to his life. Dictating had its advantages to him. It not only saved him from exhausting mechanical labor, and from bending over his desk, but from something, with his temperament, even worse-from working alone. The wholesome interest created in the mind of his first amanuensis, spread itself to all the members of the family. Even 
the younger became ambitious to copy well enough to assist their father in the mechanical part of his work.

In 1850, the General Synod of the United States met in Charleston, S. C. Dr. Bachman, wrote to a relative, May 10th.: "Our General Synod held its sessions in St. John's. Ten of its members staid at my house-and my hands were full."

John G. Morris, D. D., ${ }^{*}$ of Baltimore, tells us :

"It was the first time we had met South, and it was a happy meeting." Alluding to Dr. Bachman's earlier connection with that Synod, he continues:

Rev. John Bachman of Charleston had been for some years a leading man in the Southern Church, before he became personally known to the same class of men in the Central Church. His first appearance among them, was as a member of the General Synod in New York, in 1833, when he endeared himself to them all by his courteous manners, his high social qualities, his varied learning and his churchly activity. He was gay without frivolity, learned without pedantry, and pious without asceticism. He had already at that time, acquired a great reputation as a naturalists; but he never alluded to science without being asked a question.

On this occasion, at York, a number of us accompanied him on a botanical excursion up the Codorus Cicek, when we were compelled, not only to admire his familiarity with the Flora of the region, and his facility in discovering the names of the few plants unknown to him, but also to admire, and, at the same time to deplore, his extreme agility ; for he out-

*Fifty years in the Lutheran Ministry. 
walked some much younger men than himself, and left the older lagging far behind.

The same body convened in his Church in 1850 . Among many other acts of kindness shown, Dr. Bachman presented every clerical member of the Synod with a copy of his celebrated book, "On the Unity of the Human Race."

Dr. Bachman was probably the founder of The Literary Club of Charleston.

He was elected its first President and long retained the office. Literary and scientific attainments were necessary for membership; but it was the privilege of each member to invite a guest. These social gatherings were both instructive and enjoyable. The evening closed with simple refreshments. A hot supper would have infringed upon the rules of the Society, whose motto was "High thinking and plain living."

Healthful and vigorous, containing within itself the germs of intellectual life and growth, the Soeiety grew to noble proportions, with the promise of increasing strength and usefulness. Charlestonians felt a just and generous pride in the attainments of its members. Literary men and scientists who visited Charleston, Agassiz and a host of others, were its honored guests.

On one occasion the subject suggested for consideration was "Luther, the Reformer," and Dr. Bachman was requested to prepare the Essay. Later (1853) his Protestant fellow-citizens called upon him for a more public defence of the Great Reformer. 
December, 1833, the subject selected was: " $A n$ Inquiry into the Nature and Benefits of an Agricultural Survey of the State of South Carolina."

"The Legislature of South Carolina had made an appropriation for an Agricultural Survey of the State, and the question naturally suggested itself, - What benefits were likely to result from the liberality of South Carolina in fostering her agricultural interests?' The question was ably handled by the President of the Club, and the Essay was requested for publication."

The preface to the published pamphlet runs thus:

The writer of this Essay submits a few words of explanation in regard to the circumstances that induced him to prepare, and finally send it to the press. He has the honor of belonging to a Literary Club, composed of a limited number of gentlemen from the different learned professions, who meet weekly at each other's houses in rotation, for the purpose of interchanging sentiments, and promoting sociality. A subject for discussion is selected at one meeting, which forms the topic of conversation on the next. The question for the evening of the 28th December, 1833, was: "What benefits may be derived from an Agricultural Survey of the State." The leisure of a rainy day had enabled him to collect his thoughts on the subject, and in part commit them to paper. The Essay was therefore prepared and read without the remotest idea of publication. At a subsequent meeting the Club, under an impression that it might afford some information on a subject which had so recently been agitated at $\mathrm{Co}-$ lumbia, requested its publication, and that a copy be sent to the Governor, and to each member of the 
two Houses of the Legislature. He has yielded his assent in deference to the wishes of his literary associates, and especially to the solicitations and liberality of his friends, the Hon. D. F. Huger, and the Hon. Mitchell King.

The pamphlet was published January, 1834.

The papers read before the Society were often in great demand. Sometimes a guest from Boston, New York, Philadelphia or some other literary centre, would request the loan of the Essay to read before some scientific association of which, perhaps, they were both members, and afterwards it was published in one of the Northern journals.

Precisely at 10.30 P. M., according to rule, the debate was closed, and the company were invited to partake of an abundant, but inexpensive spreadprepared at home. Nothing stronger than coffee and lemonade was allowed. It is affirmed, however, that, on these occasions, the ladies never failed to receive a welcome tribute to their culinary skill, proving that the subjects discussed at the suppertable, were not entirely despised by these profound philosophers.

On one occasion in 1853, Dr. Bachman invited as his guest Mr. Wm. Gregg, the successful founder of the manufacturing village at Graniteville, S. C. The member at whose house the Club was to meet, lived a mile away. Mr. G. wrote to his friend: "Don't trouble yourself to order your buggy, I will take mine and call for you." At the appointed hour-off they drove. Midnight came, 
then one P. M., and still no husband and father appeared in either of the homes. At length two benighted, foot-sore, sad faced men stood before Dr. Bachman's street-door. This is the sorrowful tale they related :

"When we came out in good time from the club, the horse and buggy, which we had expected to find safely tied before the door, had disappeared, and we have been vainly searching for them all over the city." Early the following morning a note was received from Mr. G- The horse and buggy had been found near the guard-house, without a driver, and the unknown property, for safety, had been lodged at the guard-house for the night.

The next evening, on the supper-tables, in both liomes, a large envelope occupied a conspicuous place by the master's plate. It bore this inscription :

"The Adventures and Sad Consequences of a Clubnight."

The poem detailed in glowing words, the fears, anxieties and sorrows of two once well-regulated families, the heads of which, unhappily, had become Club-men. This effusion caused great mirth. Twentyfour hours later, envelopes, similar to the first, were received by the wives. They contained the rejoinder to the poem, written in blank-verse. Startling and amusing revelations were made therein with regard to the wives and children of the two friends. It was without signature, but all knew well who the author was. The issue of these unfounded accusations was a visit, that evening, from the neighbor and 
his good wife. No redress was obtained by the plaintiffs; but good-natured repartée and merry laughter promoted dreamless slumbers which renewed the energies of body and mind for the duties and cares of the morrow.

The war between the States gave the death-blow to this genial Literary Club. It died in the very prime of its life and usefulness, bequeathing as an inheritance an impress of culture upon younger lives.

In 1850, Dr. Bachman published his book on "The Unity of the Human Race."

In the preface, he says:

The Literary Club of Charleston, aware that the early studies of the author of this Essay had been directed to Natural History, and that in the pursuit of his profession as a clergyman, he had felt himself constrained by a sense of duty to investigate those branches of science that appear to militate against the truths of Christianity, had selected during his absence from the city, in September last, "The Unity of the Human Race" as a subject to be discussed at the meeting, which would next in turn take place at his house. He, accordingly, hastily prepared some notes which he read before the club.

The subject being full of interest, was discussed at several successive meetings, two or three of which were occupied in an examination of the question on purely scientific grounds. The notes made during these hours of leisure which could be stolen from multiplied avocations and cares, had, insensibly, accumulated on his hands. At the close of the discussion, those members of the club who coincided 
with him in sentiment, requested their publication; and several advocates of a plurality in the races, expressed a desire that the public should have an opportunity of becoming acquainted with the observations and views of an opponent, from whom they honestly differed. *

In discussing a subject, the most difficult in the range of the sciences, he has ofter felt himself obliged to differ from the views of his co-laborers, members of scientific associations with which he is connected-his correspondents and personal friends. He need not add that he has been studious, that no difference of views should be expressed in personal or offensive language. Men of science will fully understand this, and he only refers to it here, as an explanation to the public, to show them that a difference of opinion, can have no influence in weakering the bonds of mutual respect and attachment.

In his attempts to defend the long established doctrine of the Unity of the Human Race, he has neither sought for fame, nor courted controversy; to the former he believes that he is now indifferent, and the latter is adverse to his feelings, his profession, and the admonitions of declining life. If, in this publication, he shall inadvertently give offence, he will regret it; if errors have escaped him, he is ready to correct them; and, if he has been enabled to add any facts to the stock of human knowledge, or any argument in defence of truth, he will feel that his labors have been amply rewarded.

We quote from a review of this work in The New Englander, Boston, Mass., November, 1850.

Dr. Bachman has long been known as one of our most enthusiastic Naturalists. Various published papers of his own, and the very frequent references 
which Audubon has made to his name, attest both the variety and accuracy of his information in several departments of Natural History. More recently the preparation of the beautiful work on "The Quadrupeds of North America," has established his reputation as an authority upon all subjects relating to the Zoölogy of this continent.

Dr. Bachman's present work shows throughout that he has been long engaged in careful and philosophical investigation of topics in various departments of Natural History, which bear upon the question of the nature of a species.

Aiming to settle the question of the unity of mankind upon purely scientific grounds, Dr. Bachman discusses it in almost every aspect; and varied as these aspects are, there is scarcely one of them on which he does not cast some new light. The question of the possibility of hybrid races of animals, is. examined with great thoroughness, and even minuteness of detail; the question of varieties among the domesticated animals, is discussed with the most complete command of facts of the highest significance. The diffusion of species of animals and plants is treated with the same learned accuracy; and every one of these discussions is enriched with statements of facts, observations, and experiments, many of which are new, original, and decisive. The bearing of these facts is then shown upon the questions which relate to the origin and dispersion of mankind, with a result which is striking and happy beyond all expectation. On the whole, the work is so complete that this branch of the general subject, hitherto the most neglected, is now placed in the clearest light; and Dr. Bachman's conclusion of the derivation of all mankind from a single pair, is. altogether beyond the reach of any objection upon grounds of Natural History. No work upon the 
same subject has fallen into our hands which makes any approach to this, in the departments of which it principally treats, in thoroughness of investigation, and in the decisive and triumphant establishment of its conclusions. * * *

Dr. Summers, then Editor of "The Christian Examiner," Nashville, Tenn. (in his "Personal Recollection "), writes:

"I had the honor of editing the Doctor's book, "The Unity of the Human Race." * * * It elicited warm commendations from learned and scientific men on both sides of the water; among them the celebrated Humboldt, whose letter to the Doctor was very complimentary. I hope that it has been preserved among his papers."

In 1854 and 1855, Dr. Bachman wrote and published two pamphlets, entitled

An Examination of the Characteristics of Genera and Species as applicable to the Doctrine of the Unity of the Human Race; and,

An Examination of Professor Agassiz's Sketch of the Natural Provinces of the Animal World and their Relation to the different Types of Man, with a Tableau accompanying the Sketch.

These pamphlets were called forth by a publication entitled "Types of Mankind, or Ethnological Research based upon Ancient Monuments, etc.," by J. C. Gliddon and Nott. This work consisted of passages from Dr. Morton's inedited MSS. ; Agassiz and Dr. Peterson also contributed; but the greater portion of the work was the direct authorship of Messrs. Nott and Gliddon. 


\section{CHAP'TER XX. \\ Scientific Labors.}

An examination of the characteristics of genera aNd SPECIES-AN EXAMINATION OF PROF. AGASSIZ' "NATURAL. PROVINCES." - HUMBOLDT'S LETTER DESTROYED - LETTER FROM HENRY R. SCHOOLCRAFT, INDIAN COMMISSIONER.

THE opening sentences of the following Mono1 graph indicate the progress made in the study of Natural History during forty years-from 1795 to 1855. Referring to his boyhood, Dr. Bachman tells us of the prejudices then entertained by the community against the supposed, trifling study of Natural. History; but in 1855 he asserts: 'The advantages to be derived from the study of Natural History are now admitted by every intelligent mind.

From boyhood an enthusiast in Natural History and kindred branches of science, we find him always in full sympathy with every patient student of $\mathrm{Na}$ ture, and holding out the hand of friendship to the humblest seeker after truth. But at the same time ready, with ungloved hand, to rebuke the temerity of the tyro, who paraded his little learning.

An examination of the Characteristics of Genera and Species, as applicable to the Doctrine of the Unity of the Human Race.

So many advantages are derived from the study of Natural History, that at the present day it would be almost superfluous to do more than briefly 
allude to a fact, that now seems to be admitted by every intelligent mind. The supply of all the temporal wants of man, his fond, his dress, the conveniences he enjoys, remind him of a number of animals and plants, on which he is dependent for his comforts. There are others that are injurious to his welfare, and he is compelled to exercise his mind in warding off the danger which is to be apprehended from their pernicious influences. But, apart from the almost necessity thus imposed on him in studying the objects of nature, he finds in this employment the means of enlarging his mind, of disciplining his memory, and of exalting his conceptions of creative power. The study of nature is the study of truth, and he who reads these truths aright is rendered wiser, better and happier. $\mathrm{He}$ deems no object unworthy of his attention that is calculated to enlarge the field of knowledge, or that enables him to penetrate into the mighty plans of the Creator.

There is another important subject connected with these investigations. The most enlightened, the purest and the best of mankind, regard the Scriptures as the revelation of God's will to mankind. The book of Nature has been given by the same Omniscient Power. His word and works cannot contradict each other. The former, it is true, was principally intended to convey religious truth, and impress on the human heart the doctrines of salvation, but it should be recollected that although the Bible was not given for the purpose of teaching the sciences, it cannot, consistently with inspiration, stand in opposition to that other record of the wisdom of the Deity that is given in His works. Hence the necessity of availing ourselves of all those facilities which will enable us to interpret the laws of nature aright. It is the boast of infidelity that, 
"viewed as a narrative, inspired by the Most High, its conceits would be pitiful and its revelations false, because telescopic Astronomy has ruined its celestial structure; Physics has negatived its cosmic organism, and Geology has stultified the fabulous terrestrial mechanism upon which its assumptions are based. How then are its crude and puerile hypotheses about human creation to be received?"* Were this true, then according to the same author, "The developments of science would have rendered any new translations (of the Scriptures) altogether supererogatory among the educated who are creating new religions for themselves."

The question then naturally arises, how are these bold assertions to be met, and to what sources must the human mind apply in order to arrive at truth, and thus solve its doubts and strengthen its religious faith with confidence and hope? Certainly there is no other mode accessible to man than by studying the book of Nature with an unprejudiced mind, and with all that preparatory knowledge, that careful analysis, that patient research and unclouded judgment, which is essential in the investigation of so grave a subject. By pursuing this plan of study, we will be enabled to solve the mystery why men, writing on the same subject, have advanced such opposite opinions and pronounced such contradictory decisions. The authors of the "Types of Mankind" have, with a positiveness which is seldom found among the humble students of nature, pronounced one set of opinions, whilst the greatest naturalists in the world, Linnæus, Blumenbach, Cuvier, the two Humboldts, Owen, Pritchard, Bunsen, Lepsius, and many others, have arrived at conclusions directly the reverse. In searching more

*Nott and Gliddon's Types of Mankind, p. 165. 
closely into the qualifications of the men who have pronounced these opposite opinions, we are not left in doubt as to the causes why they could not arrive at the same conclusions in professing to unfold the leaves of the same book of nature.

Mr. Gliddon candidly informs his readers of the amount of knowledge in the sciences, which enabled him to pronounce so positive and startling a decision, that the sciences had so utterly demolished the "fabulous terrestrial mechanism" of revelation, that a "new translation was supererogatory." $\mathrm{He}$ tells his readers-" My former pursuits in Moslem lands were remote from natural science, and disqualify me from sharing the labors of its votaries," etc. Thus then we have the admission from his own pen and in print, that he is unqualified, from a want of knowledge on the subject, to express an opinion in matters of science, and yet the very sciences about which he professes to know nothing, have (in his opinion) utterly demolished the whole structure on which Christianity is founded. On the other hand Professor Owen, who has for a whole life studied the sciences, of which Gliddon had not yet read the alphabet, expresses his matured convictions in these words:- "Thus in reference both to the unity of the human species, and to the fact of man being the latest, as he is the highest of all animal forms upon our planet, the interpretations of God's works coincide with what has been revealed to us, as to our origin and zoölogical relations in the world. Man is the sole species of his genus, the sole representative of his order." In investigating those preparatory studies, by which these gentlemen considered themselves qualified to pronounce such opposite opinions, we are forcibly reminded of the caution of the poet: 
"A little learning is a dangerous thing,

Drink deep, or taste not of the Pierian spring ;

These shallow draughts intoxicate the brain,

But drinking deeply sobers it again."

The sciences in order to be understood must be studied. As there is order in all the works of Nature, naturalists have for ages past been engaged in interpreting her laws, and bringing her various productions under a systematic arrangement. By this means the study is simplified. By the co-operation of numbers, each working in his favourite department, a mass of intellectual riches is acquired, which is transmitted to their immediate successors, and through them to posterity.

We should regard it as a work of supererogation to occupy any space herein to prove that however numerous may be the varieties-or races-or species in the human family, they must all, by the rules of science, be included under one genus.

He points to Nature :

A correct understanding of the laws of Nature in the creation of species would, we apprehend, enable us to interpret her works with much greater certainty by an examination of the species and varieties she has produced, than by resorting to the monumental records of Egypt, Assyria, or of Central America.

These records he shows to have no legitimate bearing on the subject of the Unity of the Human Races.

We possess a much better guide in the designation of species, than that which could be given us by the rude stone chisel, or the painted daubs of the ancient lords of our forests. We possess the species themselves, with the characters impressed on them 
by the hand of the Creator, and from these we are enabled to decide on their identity, and from this identity we infer their primordial origin. All the fishes, and every species named by Agassiz, were described from the characters they presented in Nature, without resorting to the unprofitable and impracticable search after their primordial existence.

Wr may, bowever, here observe that the figures of dogs and of men (the latter only are of any scientific value) on the Eastern monuments, have been carefully studied and delineated by master minds-men, at whose feet Mr. Gliddon has sat as an humble copyist. They are now giving to the world the result of their scientific researches. Both Lepsius and Bunsen have already proclaimed their belief in the doctrine of the Unity of the Human Race, and the former is now engaged in a work, in which he will offer reasons for the faith that is in him. Thus these monumental records, which caused Gliddon to pronounce, in the language of scorn and obloquy, a tirade against the Scriptures, convinced the minds of Lepsius and Bunsen of their truth, and filled them with humility, reverence and awe. Their scientific researches satisfied them of the truth of doctrines proclaimed by Moses, and confirmed by Paul: "And God hath made of one blood all nations of men for to dwell on the face of the earth, and hath determined the time before appointed, and the bounds of their habitation." Acts 17:"26.

After closely comparing the different Races of Men, he says :

So strikingly similar are the characteristics in all these varieties, that Professor Agassiz himself has been compelled to admit that "Man is everywhere the one identical species." Although, in his last pub- 
lished opinions, he assumes, without giving any satisfactory reasons, that there might originally have been eight created nations, yet he is very cautious in not calling them species-and, in great doubt and uncertainty, adds:- "I still hesitate to assign to each (race) an independent origin." We are encouraged to hope, therefore, that he who has always appeared to us as a searcher after truth, and who is courteous in his language, and scientific in his pursuits, is not so hopelessly committed to an erroneous theory, as not to be induced to review the whole subject again. In the lower departments of '/oölogy, he ranks at the head of the naturalists of our country, and we are not without a hope, that after having carefully studied those higher forms of animal life, which prepare us to form an unbiassed judgment in regard to man and his varieties, he may return to his original views.

If we look for those characteristics that are essential to a species, they are found in every tribe of men in the whole earth. If we compare man with every variety in the species of domesticated animals, his variations present the same phenomena ; if we ascend higher and examine his instincts, the power of his mind, and his longings after immortality, we cannot but perceive that these gleams of intelligence and of hope exist, however partially developed, even among the most degraded and barbarous nations.

An Examination of Professor Agassiz-Natural Provinces of the Animal World in their Relation to the Different Types of Man, with a Tableau Accompanying the Sketch.

In the work called "Types of Mankind," by Nott \& Gliddon, the public is presented with a paper by 
Prof. Agassiz, on the Natural Provinces.* As every thing that has emanated from the mind of a naturalist so eminent as Agassiz is admitted to be, his views must always merit a respectful consideration, by all who are investigating the truths of nature. Our purpose in the present article is to subject this "Sketch of the Natural Provinces," with the "Tableau annexed," to a close and impartial investigation. His object, as he informs us, was "to call the attention of naturalists to the close connection there is between the geogruphical distribution of animals and the natural boundaries of the different races of man."

Prof. Agassiz admits, "that notwithstanding the diversity of his races, man constitutes one only, and the same species over all the globe." $\mathrm{He}$, however, supposes that this same species of man was created "broadcast" in groups all over the world. This would, we conceive, be requiring unnecessary miracles from the Creator.

He divides the world into eight natural realms or provinces. To each zoölogical realm he has given figures of the head and skull, of the variety of man as existing in that province, together with seven or eight animals found in the same province. This is intended "to show that the boundaries, within which the different natural combination of animals are known to be circumscribed upon the surface of our earth, coincide with the natural range of distinct types of men."

The great difficulty in the above theory seems to be-

1st. The impossibility of deciding on what are "the natural provinces of the animal world."

$2 d$. Whether the boundaries in the animal world are the same as those he has assigned to his types of men existing in those boundaries.

*Nott \& Gliddon's Types; p. 23-31. 
3d. In what respect either in form, habits, or any other characteristics, there is the slightest resemblance in man to the animal kingdom in the same zoölogical province.

When we, in 1846 , were from a kind of necessity induced to publish our views in one department of science, we were somewhat at a loss to decide on the exact boundaries to which our labours should be restricted. The following were the views which we finally adopted as most convenient, and in accordance with nature.

"We have arrived at the conclusion, that in undertaking the natural history of a country, our researches should not be confined to the artificial boundaries of States-which may be frequently changed; but by those divisions, the limits of which are fixed by nature, and where new forms mark the effects of a low latitude and warm climate." * * *

We have not seen any reason to change the views then expressed. There are natural boundaries, as we have before stated, and they will afford us some aid in our knowledge of the distribution of species, but as each species has its peculiar range, no boundaries will be found to apply to all species even of the same genus.

The labors of naturalists during the last hundred years, in investigating the geographical distributions of animals and plants, were not only harmless speculations, but added considerably to our previous knowledge of the laws of nature. But when nature. is distorted for the purpose of advancing a theorywhen selections are made, and figures given of par. ticular species of animals in an imaginary province, to the omission of others, that are more characteristic, and would materially change the whole aspect of the question; and when under the color of these erroneous views, the opportunity is eagerly seized 
on by others, in the same volume, to heap on the Holy Scriptures and its ministers all manner of derision and contempt, it becomes the duty of the naturalist, as well as of the Christian, to place the subject in its true light. This, as far as it relates to science, we are endeavoring to do in this article. We charitably hope that Prof. A. was not aware of the contents of the volume to which his paper was intended to give circulation and celebrity. That book was ushered into the world under false colors. The names of eminent scientific men were paraded before the public as pledges that a reliable scientific work would be given, and as an inducement to men to patronize it. When this long promised work finally made its appearance, it was found that these meager contributions of naturalists from stores with which the public were already in possession, had been seized on by Mr. Gliddon, to afford him an opportunity of attacking the veracity of the Holy Scriptures, in attempts to unsettle the human mind, and deprive it of all that is calculated to preserve public morals andprivate virtue, of all that enlightens conscience, and cheers us with the hope of immortality. * $* * *$

We have entered reluctantly into this long and minute examination of Professor Agassiz's "Sketch of the Natural Provinces of the Animal World, and their relation to the different Types of Man," together with "the Tableau accompanying the Sketch." The believers in' the plurality of races have heralded this and a former article, by the same writer, published in the Christian Examiner, both maintaining the same views, as new and unanswerable evidences of the truth of their doctrine. We will give a specimen: " Let us acknowledge our large indebtedness to Prof. Agassiz, who has given the most masterly view of the geographical distribution of animals 
written in our language, or perhaps in any other. Not a line can be retrenched from his already condensed articles without inflicting a wound, and we take much pleasure in referring the reader to them."*

We would not intentionally "inflict a wound" either on science or on Prof. Agassiz, since we are anxious for the promotion of the truths of the former, and entertain a personal regard toward the latter on account of his worth as a gentleman, and his indefatigable labors as a naturalist. Whatever scientific errors we may have committed in this review, we are prepared, if they are pointed out to us by a competent naturalist, thankfully to correct, and if a word has fallen from our pen that can be construed as personally offensive to him, we will, with regret for the error, cheerfully erase it. Our sole object has been to present the truths of nature in the light in which we conscientiously regard them, and, as far as we are able, to avert those injurious effects on the faith and hope of man, that may be produced by errors in science.

A letter from Humboldt, with other valuable papers of this date, has, unhappily, been destroyed.

The following letter is from the distinguished United States Indian Commissioner, Henry R. Schoolcraft, who conducted the expedition when the long-sought-for source of the great Mississippi was discovered.

Washington, Sept. 23d, 1854.

My dear Sir-I have received and perused your notice of the "Types of Mankind;" and though writing to me has become laborious, (for I am obliged to guide my right hand with my left,) I cannot re-

* Nott and Gliddon's Types of Mankind, p. 72. 
frain from expressing to you my thanks for this service to the cause of truth.

The Types are, indeed, the fruits of the mountain that was in labor. From one end of the land to the other, subscribers have been drummed up for this work; and when it come forth it is a patch-work of infidel papers from the living and the dead, by which we are informed that the Hebrew Chronology is false, that Moses was a demogogue and an imposter, and that Christianity is a deception.

Well, if this be all that America is to send back to Europe, after boasting of her rich stores of learning: science, philosophy and religion for three Centuries; it were better that the Aborigines had maintained their dark empire of pow-wows and jugglers, undisturbed.

The Indian, had at least, the merit of directness in his theological dogmas, and worshipped the devil without disguise, whereas, such men club their wits in this attack on Christianity, and conceal their real aim under the guise of a philosophical inquiry.

Very sincerely your friend,

H. R. S. 


\section{CHAPTER XXI.}

\section{DEFENSE OF LUTHER.}

Personal recollections, by dr. summers- defexse or I.UTHER AND THE REFORMATION-LINES ON A FLYLEAF, BY DR. JOHN L. GIRARDEAU-NATURAL HISTORY FOR CHILDRKNHOBBIES-SNUFF.

$\bigcap_{\text {writes: }}^{R . ~ S U M M E R S ~ i n ~ h i s ~ " P e r s o n a l ~ R e c o l l e c t i o n s . " ~}$

"I never knew a man, who had more regard for "our poor relations" than Dr. Bachman. It was not confined to the noble horse and sagacious dog; but it seemed to embrace every thing that had the breath of life.

"The Doctor was so seated in the hearts of his parishioners, that they almost worshipped him. Indeed, he was reverenced by nearly the whole community. He was not much loved by the infidels, whose " science falsely so called," he so utterly de-. molished. Some of our Roman Catholic brethren disliked him and not without cause. He defended the character of Luther from their defamations; exposed the licentious doctrines contained in Den's Theology, one of their text books, which they affected to deny, and carried the war into Africa, by showing the demoralizing influence of the Confessional. $* * * *$ In his controversy with the papists, the Doctor was goaded to unusual severity."

While some of his Roman Catholic brethren, may have disliked him heartily, yet others appre- 
ciated the fact, that in the public defense of Luther he acted not from personal feelings, but from principle and a sense of duty.

We recall a hospitable home, under the shadow of St. John's Church. The aged host, Mr. P., though a Roman Catholic, delighted to entertain and to refresh the Pastor of St. John's.

On the occasion of a serious railroad accident, near Branchville, S. C., Dr. Bachman was at hand and gave efficient aid to the sorely bruised and wounded. With words of sympathy and encouragement, he endeavored to sustain their fainting courage, until the means of transportation could be obtained. Among the sufferers was a Mr. R., a Romanist, who, from that hour, frequently expressed in grateful terms his admiration for a man whose charity was not confined to those of his own creed and confession.

In 1853, Dr. Bachman published "A. Defense of" Luther and the Reformation."

He writes in his preface to the same:

At the commencement of the controversy, I had no idea of writing more than four or five articles in defense of Luther. Having, however, been continually goaded on by the attacks and denunciations of the Catholic Miscellany, I concluded that my indomitable opponents could be best met by carrying war into their own camp. I had hitherto been disposed to leave the cause of Protestantism to the defense of those better skilled in controversial theology: the attack, however, on Luther, in my own city, under circumstances most aggravated and 
insulting, left me no alternative between a pusillanimous silence, which would have been construed into an admission of the truth of the charges, or an open, fearless defense.

An ex-monk of La'Trappe, Rev. Leahey, who was in connection with the Dutch Reformed Church, advertised to give a lecture on "Popish Confession and Priestcraft." Ladies and youths were prohibited from attending the lecture. The announcement created great excitement among the Romanists of Charleston. One of the proprietors of the American Hotel (where Rev. L. boarded) applied to the City Council to know if the Corporation would be responsible for damages to his property if the lecture was given in his hotel and a riot ensued. Rev. L. was also present, showed his credentials, and asked permission to give the lecture. The City Fathers were divided in opinion, and a discussion ensued. One of the Aldermen, disclaiming any knowledge of the Reverend gentleman present, or of his lectures, remarked: "The Rev. Bishop Johı England, arrived in this city thirty-three years ago, and delivered, weekly, a course of lectures to prove the Scriptures to be a divine revelation from God. His remarks against the Protestant churches in this city were very severe; but he was ably answered by the Rev. John Bachman, D. D. At that time there was no riot or disturbance of the public peace, and why should there be one now ?"

An Alderman, a member of the Roman Catholic Church and an eminent physician, replied, that 
"In those lectures Bishop E. had not treated of topics not mentionable to the chaste ears of females or youths, or charged upon the present generation of Protestants the immoral practices licensed by their 'Chief Reformer,' the sanction for which is extant in his own writings."

Some of the Aldermen were in favor of the right of free discussion by lecture or sermon, let the consequences be what they might; and some expressed a willingness to concur in prohibiting the lecture, " could it be made to appear that the Council possessed the constitutional authority to do so." Legal opinion was taken, and the City Council decided that they had no authority to prohibit the lecture; but that the Corporation would not be responsible for damages in case a riot ensued. The lecture was not given.

A communication was published in "The Charleston Courier" by the Roman Catholic Alderman, reporting the discussion touching Leahey's lectures; which was copied in the " 'atholic Miscellany." Rev. B. Gildersleeve ( publisher of "The Charleston Observer," in connection with "The Watchman of "the South," at Richmond, Virginia,) thereupon took up the gauntlet, and replied in two letters.

Dr. Bachman gives his reasons for entering into the controversy:

"The multiplied calls on niy time, and my period of life, would lead me infinitely to prefer the rest and quietude of my own thoughts, agreeable studies, and ministerial labors and associations, to the ex- 
citement, and often embittered feelings, which are engendered by a religious controversy. When, however, great principles are to be defended, and the reputations of the benefactors of mankind are to be rescued from defamation, it then becomes our duty to lay aside, for a time, our more agreeable occupations and to battle manfully in the cause of truth, of justice, and the pure principles of Christianity.

As a native American citizen, and an inhabitant of Charleston for nearly forty years, I have felt deeply grieved that an attempt has been made, resulting in partial success, by a Roman Catholic Alderman, to deprive one who professes to be a Protestant clergyman, of the privilege of free discussion in matters of religion; and he, as a member of the (ity Council, voting against his being protected from a Roman Catholic mob.

* * * * * * * * *

Men's characters are formed from the school in which they are educated. The principles we have imbibed, influence our character and conduct.

The Roman Catholic is taught to render implicit obedience to the Church. That Church he believes infallible. * $\quad *$

The Protestant founds his religion on the teachings of the Scriptures. * * * If the Reformers were not perfect in their lives, this does not affect his religion-that is derived from the Scriptures, not from the opinions of men. He believes the true Catholic, or universal Church, is composed of the pious and good of every tongue and nation, and every form of religion, and that Jesus Christ is the Head of the Church.

The time now had come to test the efficacy of these different teachings, in the same city, (Charleston), and within a few days of each other. 
Leahey was about to give a lecture, as he, at the time, informed some of the clergy, on the impure tendency of Den's Theology and other Roman Catholic books which are used in their seminaries. He requested that women and children should not come to the lecture, as he was about to make "awful disclosures." From the nature of Den's Theology, which directs the priest how to ferret out the secret thoughts of woman's heart, I should be sorry to hear it detailed-even to the ears of men. At the first publication, however, of his intentions, a mob gathers around his lecture-room, and neither the laws of the city, nor the power of their Bishop, nor notices read from their pulpit, could restrain the Romanists from threatening violence and blood. The man was compelled to flee.

About the same period a Roman Catholic Alderman did not threaten only, but actually made and published "awful disclosures," professing to convict "the Chief Reformer of the Protestant faith with immoral teaching, and plainly sanctioning concubinage, polygamy and adultery." And what was the effect on the Protestant part of the community, especially on that branch of it which professes the Evangelical Lutheran faith? * * * They are composed of men of all ranks - high and low, educated and ignorant, rich and poor, from the Chancellor on the bench to the laborer on the railroad. They revere the memory of the "Chief Reformer." What was now their conduct? Did a mob threaten to pull down the house of the offending Alderman over his head? Was it necessary to call on the City Council for protection? Did their ministers find it necessary to issue a bulletin to their people, imploring them to keep the peace? No! their answer was, "We will tolerate error as long as we have truth to combat it with." 
During the controversy occasional letters signed "Many Protestants," appeared in the Charleston News, showing the deep interest felt by the Protestant part of the Community in the defence of Luther. On the Romanist side, Dr. Lynch, (afterwards Bishop) and others appeared.

The Watchman of the South, and leading Protestant Journals, united with the Charleston community in the request, that the defense of Luther should be preserved in a permanent form.

The following lines are found on the fly leaf of a copy of Dr. Bachman's Defense of Luther, in the hand-writing of his friend, John L. Girardeau, D. D.:

"When the great German Reformer and the Protestant Reformation were assailed in the Council Chamber of Charleston, Dr. Bachman intrepidly came to the front and vindicated them in the impregnable argument of this book.

"John Bachman was one of the noblest men I ever knew, and one of the most glorious men of this century.

"As an original observer in the field of Natural History, he did not have an equal in this country, and no superior among his cotemporaries in Europe. His personal investigations went far towards settling the question agitated in his day, of the Unity of the Human Race. He was equally remarkable as a practical philanthropist. By night and by day, in sunshine and in storm, he ministered with unwearied assiduity to the sick and the poor; and when the destroying angel swooped down in season of epidemic, he opposed him, as if he were an angel from Heaven vested in the garb of humanity.

"When Bachman died, Science and Religion 
walked arm in arm and together laid their blended wreaths of laurel and cypress upon his honored grave."

The controversy ended and the book published, Dr. Bachman turned to more agreeable occupations, among these were stories on Natural History, for the instruction and amusement of children.

Dr. Summers, then editing the Sunday School Fisitor in Charleston, writes :

"I furnished the Doctor cuts of animals, and he wrote charming articles for the children, which were highly prized by the readers of that periodical. I preserved the bound volumes for the four years I edited. it, but they were destroyed by fire in 1872 . I hope that files have been preserved by others, that these admirable communications may be reproduced when the Doctor's literary remains shall be published."

We remember this bright, fresh series of Stories on Natural History, welcomed and enjoyed by parents as well as children, copies of which were preserved for years in the Pastor's home. Unfortunately they have been destroyed.

He had many hobbies-his garden, poultry, bees, etc., and he led hosts of his friends to find healthful. occupation and amusement for their leisure hours.

He was very successful in rajsing ducks. Just beyond his vegetable-garden there lay a salt-water pond. Here he set traps and caught by the wholesale minnows, eels, etc., to feed his ducks, and they. 
repaid him for their generous diet. One year he raised over three hundred.

Dr. Summers writes:

"Of course the Doctor went into the rage for Shanghai Fowls, when they came to the 'fore.' $\mathrm{He}$ showed me one day, a hen which laid one hundred and twelve eggs in one hundred and sixteen days. She did not keep many Sabbaths! Of course she was a great pet.

The Doctor came to our office on one occasion in a pleasant mood, and said: 'Summers, I'm going to Synod, and I will give you a Shanghai cock and two hens of my fine breed, if you will preach for me in my absence, and Wightman, (afterwards BishopMethodist Church), I shall make the same bargain with you.' We both agreed. I remarked that I must have the fowls in advance! The fowls came-fine, fat fellows, and the sermons were preached."

His fine ducks, Shanghai fowls, etc., he frequently distributed among his friends.

From his son-in-I,aw, Mr. Haskell.

"I thank you very much for your present of fine Shanghais; I cannot get Harriet to send you the five fat hens promised; but you shall have them, if I have to steal them from her. Come up to Oakland, I an keeping all the deer for you. Three were started yesterday, but none killed.'

From his Daughter Harriet :

My dear Father: Don't believe a word Mr. H. says about the hens. I am so anxious to get them to you, that it was as much as he could do to prevent my sending them to you by Ben on horse- 
back, in the market-basket. I write to ask you to come up as soon as possible, and take your pick of the finest. The Shanghais are doing well, notwithstanding sundry visits from the rats. I have named them after five young gentlemen, and have already selected the names of the three Lady-Shanghais I wish you to save for me. If you succeed in procuring the ferrets, Mr. $\mathrm{H}$. asks that you will give directions with regard to the mode of keeping them, etc. * * *

P. S.-Little John Bachman, says, " tell Grand-pa, I never cry now when I am washed." We have made a rule that he shall only ride on his pony when he is good. * * * H. E. H.

'The Synod of South Carolina convened at St. Matthews. Dr. Bachman, wrote :

To Mrs. BachMaN :

St. Matthews, Nov. 12th, 1853.

We arrived here in safety, found carriages in superfluity at Lewisville. The land is flowing in abundance-turkeys, sausages, pigs, and everything else to cause a man to eat to fulness and invite dyspepsia to take up his abode within him. I am quite well, but sleepless. I am either too much excited by talking with my old friends, whom I have met again after a year's separation, or I have laid in too many creature comforts, or taken too strong coffee, or breathed too much of the smoke of the Indian-weed. Which it is, I know not; but I have not had one hour's sound sleep since I left home. I shall, however, make a desperate effort to sleep tonight. I have eaten no supper, changed my room- 
where I shall not hear S- snore, and I have barred the door against tobacco smoke.

1. We have much business before the Synod, and I really cannot guess when we shall get through with it, certainly not before Wednesday night. I shall write you again, if possible; but we are some miles away from the Postoffice.

Dr. Bachman disliked the smoke of the weed, but he enjoyed a pinch of snuff. Dr. Summers tells us that his friend, knowing his aversion to snuff, used to tease him by taking out his snuff-box.

"Opening and tapping it as only an inveterate snuff-taker can do it, he would proffer it to me to excite my impotent rage. But one day he talked about it very seriously, deeply regretting that he had become a slave to the bad habit. He said that he once determined to break his chains. He took passage in a sailing ship from Charleston to Europe, filling his snuff-box, but taking no further supply. There are no tobacconist's shops in the Atlantic, so that when his box should be emptied, he could not replenish it, and thus he would break the habit. Several young men took passage with the Doctor. In two or three days he exhausted the box. The first day after, he felt moping and uneasy, and the next day nervous and petulant; the day after that, ready to jump overboard. The young men, who were watching him closely, having got wind of his intention, smuggled a bladder of snuff into his state-room. He told me that when he saw it, he plunged incontinently into it, and snuffed and snuffed again. He had enough to last him the whole voyage, and never did attempt to break his chain; and never after this confession did I abuse him for snuffing." 
But later Dr. Bachman broke his chains. With his indomitable will, he could not, without continued struggle, remain a slave to a habit he deplored.

At the close of the war, (1865), he wrote to Mr. R. G. C., a member of his congregation, thanking him for sundry useful and valuable gifts.

"My heart is overflowing with gratitude, more than language can express. I ought to suffer with the commnuity around me-and I have not suffered in proportion "with others. One thing, however, I have done, I have practiced a little more self-denial. I had been a snuff-taker for forty years, and I had tried three times to wean myself from the vice. I have done it effectually now, and my snuff-box is lying idle in my daughter C—-'s desk; so I use neither spirits nor tobacco in any form."

This was nine years before his death. He never once again " opened and tapped his box," proffered it to a friend, or tonk a friendly pinch from his neighbor's snuff-box. 


\section{CHAPTER XXII.}

\section{A Visit to Frorida.}

ScIENTIFIC AND PASTORAL WORK-IN THE HOME-THE MIRABILIS-HIS AMANUENSIS-ANXIOUS HOURS-A SUCCESSFUI, HUNT-VISIT TO FLORIDA.

THE Correspondence preserved during the years 1 185t, 1855 and 1856, would indicate that these years were, humanly speaking, uneventful to the subject of this memoir.

Perhaps a suitable heading would be work. Scientific articles and pamphlets published and in course of preparation, general work undertaken for the benefit of the community at large, work appointed by Synod and, abuve all, his life-work-the charge of St. John's-on the Pastor's side, earnest, faithful service, on that of his large congregation, unfailing confidence and consideration.

In his home we trace the gentle courtesies that softened the cares and sorrows of life. Like the calendar, they began on New Year's Day, and continued until crowned by festive December.

Found on the fly leaf of a Note-book.

To Mrs. Bachman :

JANUARY 1st, 1855.

"The Spring and Summer time of life passes onward to the sober realities of Autumn and the Winter's storms; times and seasons change; but 
affections, founded on intelligence and worth, are perennial. Like pure streams flowing through the valleys, they widen and deepen until they are purified and perpetuated in the wide ocean of eternity.

J. B."

Copy of leaf dedicatory in " Wood's United States Dispensatory."

My Dear Wife - If I supposed that you were fond of finery, I might have given you a silk dress, or a Cashmere shawl-which you fully merit; if emulous of articles of taste and extravagance. I would have selected books of engravings in gilded and embossed binding. But, as your tastes are simple, practical and economical, allow me to present you with a good family book, full of knowledge and calculated for daily use.

Your devoted husband, J. B."

DEC. 25th, 1855.

We have alluded to the mirth-provoking rhymes that were frequently placed on the Pastor's plate at table. These compositions were written at the instigation of the younger members of the family-Mrs. Bachman was generally the composer. If the hits were too hard, the Pastor's blank verse was always ready at hand. He would laugh and say, "In my youth I indulged in writing poetry, and sent my early effusions to the village newspaper for publication. Then I waited, with no little interest and curiosity, for the comments and criticism that were sure to follow. One day I drew out a remark from a gentleman whose opinion I valued on this subject. Pointing to the paper, I said: "W' hat do you think 
of this poetry?' He replied: 'The fellow who wrote it would, probably, do better at the plow.' From that time I saved quires of paper, and much precious time." But his home effusions were given to far less critical ears, and were received with hearty greetings and followed by genuine applause and merriment.

Mrs. Bachman's poetry was very simple, written for the pleasure and amusement of the home circle. One of her best was:

"The Appeal of the Mircbilis" (Four O'clock).

Dr. Bachman had become weary of these fragrant Howers that grew year after year in the little plot before his study windows, and he bade the gardener pull them up. But the little silvery tongued messenger came in and appealed to so many tender memories in his heart, that the gay old-fashioned, unpretending flower was allowed to remain and to bloom, undisturbed, year after year.

To Mrs. Lucy Audubon:

March 30th, 1856.

As your old and faithful correspondent and friend, is now, by the will of a Wise Providence, deprived of the privilege of writing to you or to any one else, I write to give you the sad particulars.

- When she was at New Orleans, on her way to Cuba with our dear Eliza, her foot slipped and she injured her right arm in the fall. At first she complained of the pain at intervals of three or four months, then more frequently; but for two months past, the pain has been incessant, and the hand has become helpless. 
To one of her active habits - so fond of painting, sewing, and corresponding with her friends, it is a very great deprivation. Our daughters do every: thing for her comfort; but she inisses the privilege of occupation; and regrets most that she can no longer be useful to me and to those around her.

Her physicians think that even amputation would not prevent her constitution from being hopelessly shattered. To myself her present situation is full of foreboding and terrible anxiety. She has been a mother to my children-my adviser-on whose judgment I always relied; my companion, my help in all things. Conscientious in all her duties, gentle and confiding, my home would be desolate without her.

My children and grandchildren are all devoted to her. I shall be glad if you will all write to herwrite cheerfully, and, as far as you can, encouragingly. She is not naturally buoyant in spirit; but her mind is well disciplined in the school of trial and adversity.

In all other respects Providence has smiled upon us. I am able to attend to my ministerial duties, and on last Sunday, had an accession of twenty to the Church.

$$
\text { With love to all, * * }
$$

J. B.

'To Victor Audubon :

As your Aunt Maria is unable to write, I answer your letter; she is trying to write with her left hand, but she is so inexpert, that you would not recognize the writing as coming from one belonging to our house. Her right arm becomes every day more rigid, and what will be the result, God only knows. she has long been to me more than a right hand, and it is my duty now to cheer and encourage her, 
and to make her life as pleasant as kindness and devoted affection can render it. She bears all with great patience and submission. She is in my study seated by my side.

We are sorry that you have not been well. Aunt Maria begs me to say to you, that a few weeks spent in old Charleston would cure you. Our Winter was severe, and the Spring is backward; the Jasmines are now in full bloom, our Wistaria is superb-and our hearts are open to welcome you. Can you not come on and see us?

P. S. From Mrs. Bachman:

With my left hand I will add, that I believe the sight of you, would do me more good than all the Doctors.

You remember the fall I had in New Orleans. I must, then, have dislocated my elbow, which now, after the lapse of sixteen years, renders the arm useless.

M. B.

The following February, (1857,) Mrs. Bachman's health was yet more seriously undermined by an attack of pneumonia. Her physician, fearing that in her enfeebled condition her constitution could not stand the shock of such a disease, prudently concealed from his patient the nature of her disorder. When it was found necessary to call in a consulting physician, he came as a friend and brought with him a specimen of a rare plant, saying, "We want you to help us to find the name of this strange plant. When we doctors are puzzled in Materia medica we come to you; but first you must let us help you to get rid of this wretched cold." 
Her husband could not trust himself near her for more than a few minutes at a time, lest he should betray his fears and anxieties. He had begun to have his flower-garden dug up and enriched in trenches; here he spent most of his time, to be within call, if she should suddenly grow worse. The passer by who watched him apparently entirely absorbed in his work, never guessed the motive-the almost necessity for bodily labor. When the trenches were finished, they were found to be too deep, only the roots of the most vigorous plants reached the rich soil beneath; his friends understood the cause of his too thorough work in his flowergarden.

To Victor Audubon.

March 2d, 1857.

To-day, I can write you encouragingly with regard to my good wife's health; to-morrow I shall take her to "Kalmia" to spend a few weeks with her friend, Mrs. Gregg. I shall come down always at the elose of the week. I find myself enjoying life, and still able to go through a certain amount of

Mrs. Bachman's condition for some time kept me much at home-my mind was too anxious to allow me to read or to write with any composure or satisfaction--I found resources in my gardens and poultry. I have been very successful in raising both vegetables and poultry, and am, almost independent of the market.

Come to us about the first of October, and perhaps I may spare time to go with you to Florida-the 
finest Winter climate in the world. We all long to hear favorable news of your health. ****

$$
\text { J. B. }
$$

In November, 1857, six of his grandchildren were ill with "Scarlet Fever;" John Haskell's case was mild at first, but a relapse brought him to the borders of the grave. His grandfather anxiously watched at his bedside-the attendant physician had abandoned all hope of his recovery. John Haskell used to say, in reference to this illness, "My grandfather's prayers brought me back to life."

To John Audubon:

Charleston, Dec. 17th, 1857.

"Another year is drawing to a close. how rapidly time flies! Old reminiscences crowd into my mind. I embrace the leisure of a rainy morning to answer long neglected letters-yours is the first on the list.

The sick, thank God, are all better. Mrs. Bachman has gained seven pounds, although she now reaches but seventy-eight pounds-the weight of three well fattened old gobblers. Haskell's children are all in health again. John, who was so very ill, came from the country last week and paid us a visit.

I have been troubled with dyspepsia, I sleep badly and have night-mare; but I know the cure-the country and an ambling pony. So I said last week, I will go to 'Goose Creek' and take a hunt, and defy this intruder on my repose. I went, but was called home by a sick parishioner, two hours after I had been in the woods. I was, however, so fortunate as to kill one young buck and to wound another, which I suppose the boys captured. I could not re- 
main, but hastened home. Even this snatch of country air did me good-I must go again. Since the planters have fenced off intruders and given up hunting in Summer, the deer have increased beyond our expectations. They have, on several occasions, started forty in a morning-and once ten were in a gang.

My son $\mathrm{W}-\mathrm{m}$ and his wife are here to spend: the Christmas holidays. I wish you were with us to join them to-day at dinner; we are to have $a$ lacunch of venison and a wild turkey. IW-m longs to get into a snipe-bog-an amusement which I should not much relish. Sons and daughters are all well.

My little grandsons come over almost every morning to join me at breakfast. With love to all, and hoping to see some of you in my home.

$$
\text { Affectionately yours, . J. B. }
$$

To THE SAME :

"You asked me in your last to give you an account of our visit to "Liberty Hall," Goose Creek. My old friend B. went up with me and we gave one day to the ducks and small game, and another to the deer.

The duck-shooting was moderately good. I could not crawl in the mud, or wade up to my waist in water, so that I took them on the wing; sometimes I tumbled over one or two fat fellows at a shot, and then again only made the feathers fly. I bagged some Wood-cocks and a few Partridges; there were no Snipe, and, when I had a chance at a couple of old Gobblers, I had only Snipe-shot, so I saved my powder and my credit, and let the Gobblers run:

The Deer-hunt was worth talking about. We had two young fellows with us, who now and then hit-. 
but their general rule was to miss. We heard them banging away at the Deer right and left-they seemed to have all the fun to themselves; but whon they had taken seven shots, and killed only a young buck, our turn came. Two Deer came in sight of B., he fired and wounded one, and the other came in $\mathrm{my}$ direction. I fired at ninety-two yards, and off he went. Soon after, B.'s wounded Deer hove in sight and I rolled him over in fine style. The splendid doe I had fired at, came now within a few hundred yards, and, with a single shot through the lungs, fell dead. We kept our stands and sent the driver back. Soon three Deer came in gunshot of B. He dropped one on the spot, and wounded another; the third, a roaring buck, came towards me like a hurricane; I pulled trigger and he made half a dozen somersets, managed to leap the fence, and then gave in his adhesion. The boys took a seven mile chase and captured B.'s wounded Deer.

We had six Deer strung up under the old pecannut tree, and we felt that we had glory enough for one day. Tell me, can you get up such a pleasant little hunt anywhere in the neighborhood of the Palisades? John, how you would have relished the fun? * * *

Long Swamp, Marion County, Fua., April 1st, 1860.

My dear, blessed Wife: Night before last was a very happy evening to me. Col. S. had taken me on an expedition of sight-seeing and of pleasure to Withlacoochee river and to Panasofkee Lake, where we remained two days. We returned Friday at five P. M. It was mail day and I hoped to hear from home; so off we started through the pine woods and circled around the trees for sixteen miles. At eight o'clock, P. M., in the moonlight, we reached our destination. Sure enough, there 
was your long and most delightful letter, written with your left hand. It repaid me for my night's ride; it relieved my mind of anxiety and enabled me to sleep like a top. Thank God for all his goodness!

I preached to-day, (Sunday), and baptized Bachman Hazelius - a boy of twelve, with a skin as black as Corvus-Americanus. Now I think that it will be no sin, and no playing the April fool, if I write you a letter.

My health has improved greatly, my disease was checked and nature worked the further cure.

We have venison every day, and enioy the finest fish that ever floated in a transparent lake. I partake of food moderately, and, at night, take a cun of tea, but eat no supper.

The Geological structure of this country is most interesting, but very simple-it is almost a uniform level. The land, like the bed on which Charleston stands, has been formed from the ocean. 'There have been upheavals throughout the whole Statethese have produced fissures in the lime-stone rocks beneath, the waters percolating through the sand, are purified and beconce like crystal. These are discharged into innumerable lakes-Griffin, Orange, Ware, with smaller lakes, every eight or ten miles, abounding in the finest fresh-water fish in the world.

There are scarcely any rivers in Florida; even the St. John's River is but a succession of lakes; the streams, such as they are, run from South to North. It is a singular country. Suddenly-in a single night, half an acre of ground, it is said, settles down, perhaps twenty feet, and is found full of crystal water, large fish, and now and then an Alligator-all carried through some underground railroad.

One thing has struck me every day; for twenty 
miles there may be no settlement, yet you cannot divest your mind of the idea that you are in a finely cultivated country. The prairies look like farms; the Live Oak and Orange groves, cause you involuntarily to look for the farm-house. Moreover, the whole country is full of cattle-not wild; the shepherds drive them up, and mark them, at least, twice in the year. This was the country for the lazy Indian; fish most abundant, game plentiful, the Kunty-root for bread, plenty of light-wood, herds of cattle, Iudian ponies, pumpkins, melons, groundnuts and sweet potatoes-the latter remaining in the ground, and growing larger with age. Then the rich hammocks-fifty bushels of corn can be raised to the acre.

I have been much gratified at finding many specimens in Natural History that the world knows of only by'name, and several species of undescribed plants. The Deer are not plentiful-they have been killed by the disease called "black tongue."

They are fast clearing out the Cougars in this part of Florida-we staid with a gentleman who has killed upwards of ninety. We saw their tracks and those of the Bear at Withlacoochee. Here the Parroquets fly about like Wild Pigeons, and I found the Florida Jay breeding here; I saw about fifty Whooping-Cranes, examined their nests and hope to bring home their eggs, of which Naturalists, as yet know nothing.

I have given the Colonel a lesson in Wild-cat hunting, that I think will enable him to rid himself of these pests. 'The boys go out at daylight with the dogs, and the Cat is treed. They blow the horn; then we ride up, rattle the buck-shot around his ears, sling him behind the saddle and go home to breakfast.

I wish that you could have seen us bobbing for 
Trout on the lake. I caught one that I think might have served to feed our whole family. There were Bream and Perch caught that weighed from two pounds to perhaps four. I shall see you on Saturday next. Ask me then whether the Trout are as big as little $\mathrm{J}$.

Love to all,

J. B. 


\section{CHAP'TER XXIII.}

\section{Work for the Church.}

AT SIXTY-EIGHT VIGOROUS AND HOPEFUL-EVEN TENOR OF LIFG BROKEN BY DEATH OF A BELOVED DAUGHTER-SERMON ON FORTY-THIRD ANNIVERSARY OF MINISTRY IN CHARLESTON -AS PREACHER AND PASTOR-PROGRESSIVE SPIRIT-SOUTHERN BOOK OF WORSHIP-A COMMON SERVICE-LUTHERANIS Y STURDY AND UNCOMPROMISING-NEWBERRY COLLEGE-DRS. STORK AND BROWN.

In 1858 , at the age of sixty-eight, Dr. Bachman spoke of himself as an old man; but, in fact, he was then scarcely beyond the prime of his rich, full life. We quote his words, used after anxious and exhausting labors; "I know a cure, a run into the country, and an ambling pony. Providence has smiled upon me, and I find myself enjoying life and able to accomplish a certain amount of labor"-and this was no small amount.

In the winter-home of his son-in-law, Mr. W. E. Haskell, he enjoyed, besides his panacea, "country air and horseback exercise," the society and devoted attentions of his daughter, Harriet Eva, Mrs. W. E. Haskell. There was a singular congeniality of temperament between father and daughter; alike energetic, buoyant, and loving, the interchange of visits, after her marriage, was looked forward to with mutual delight. 
In April, 1858, his daughter's family formed part. of his household in Charleston. On the 12th of May, an event occurred, that broke in upon the even tenor of his life, and overshadowed all its brightness-the death of this beloved daughter.

Mrs. W. E. Haskell, at the age of thirty-five, was laid to rest, with her baby at her side.

The country home, where he had spent so many happy days, was forthwith abandoned, and his four granddaughters from that time became members of his household (John Haskell remaining with his father.)

Again the Pastor of St. John's closed the door of his study, and gave one day to " the luxury of grief." Then he came forth bravely to meet the labors and cares of life; but, when the shadows of evening lengthened, and the pressing duties of the day were ended, tender recollections of the young life that had been his pride and joy, flooded his heart. He would sit rapt in thought, until aroused by the voices. of his little grandchildren singing their evening hymn.

January 10th, 185S, Dr. Bachman celebrated the forty-third anniversary of his ministry in Charleston. We give a few extracts from the sermon preached on that nceasion.

Deuteronomy Chap. IV, 32. "Ask now of the days that are past."

The traveller wearied and perplexed by the occurrences on the road, sometimes sits down to review his travels, and recalls to his mind the pleas- 
ant or the painful occurrences on the road. He hopes to be profited by the recollection of the past failures or successes. He looks forward with intense anxiety to the end of his journey, and anticipates the pleasure of meeting again with those, from whom he has been separated for a brief season. In the same manner, the Christian traveller has his periods sacred to thought; and with regard to his spiritual life, he often pauses to ask of the days that are past.

In the life of your aged pastor, this is one of those solemn periods, pregnant with recollections, through a long series of years, in his ministry. Come then, my Christian friends, let us calmly, earnestly, and prayerfully, ask of the days that are past.

It does not become me to dwell on my own labors in this congregation. I feel how imperfect are the best efforts of man; wherever there have been successes, let us ascribe all the praise and glory to God, to whom they legitimately belong. Men are but the instruments, and $\mathrm{He}$, the Master, often gives the blessing, while the servant is unworthy.

There are at present 352 whites entitled to communion in this Church. Of these nearly 100 have removed into various parts of the country, but still retain their membership with us. The colored communicants amount to 198-making in the aggregate 550 .

During my ministry of forty-three years, I have baptized 4,085 children and adults, 1,835 of these were colored. I have confirmed and received into the communion of the Church $2,100-800$ were colored. I joined in the holy bands of wedlock 910 couples, of these about 300 were colored. I buried 1,210 whites (I have no account of the funerals of the colored communicants, as their funeral services were generally performed by their leaders.) * * * It is scarcely possible to preserve a perfect accuracy 
in these records; and I have learned from long experience, that many mistakes and omissions unavoidably occur.

The above will give you, however, some insight into the lights and shadows in the life of a clergyman. His moments of enjoyment are succeeded by hours of anxiety and days of sorrow. "Those whom he has baptized and admitted into the Church, he looks upon as his children. If they are pious and happy, the Pastor's heart rejoices ; if they become careless and unfaithful, he is deeply grieved, and when they are separated by death, he mourns over: them as a loss in his own family. * * *

Alluding to the changes which death had wrought during his ministry, from 1815 , he tells us:

When I arrived among you, our country was under the administration of Madison, the fourth President of the Uniter States-all but Washington were living-these are now all dead; and, of the nine Presidents that, succeeded him, six are also in their graves.

On my arrival in Charleston, I became a member of the German Friendly Society, which was then composed of nearly one hundred members-these have all passed away, and I am now the oldest member.

Of the few communicants I found in this Church on my arrival, one only is now alive. Of the eleven whose names were signed to my call-nine vestrymen and four wardens-all are gone to their account. Of the committee of twenty-one, who, in 1815 , reported on the expediency of building this Church, all are dead. Of the Pastors who occupied the pulpits of our city on my arrival, not one is living. Of the managers of the Bible Society, who 
met in 1815 , I only am left, and, of its members, I am the oldest on their record.

At our first confirmation, in 1816, sixty-four persons were dedicated to God, nine only are now alive. Nearly all of these are now before me. You, my dear friends, who were the first fruits of my ministry-you are all that are now left of that crowdthe rest have fallen by the hand of death, and become the tenants of the devouring grave. You, my friends, will surely draw near to me in my decline of life, and exhibit to the younger generations your faith in God, your love and constancy to the Saviour, and your assured hope of everlasting life. * * *

Little remains of that thread of life which has been spun out in the midst of you. In a few weeks I shall have attained my sixty-eighth year. I would not wish to recall that life, unless it could be spent in greater usefulness to you and to others. I trust, through the mercy of that Saviour who died for a fallen world, that I shall be prepared cheerfully, whenever $\mathrm{He}$ shall see fit to call me hence, to resign my spirit into the hands of that God who gave it.

This congregation is the only one I have had the charge of since my ordination. I did not hesitate for a moment to give a negative reply to all invitations from other sources in the Church, and from seats of learning-offering higher pecuniary advantages. I came not to seek your wealth-a minister, who is devoted to his duties, has no time to lay up treasures of earth. He is commanded to use hospitality to the household of faith, and more especially to his brethren in the ministry. He is liable to daily calls on his income, for he must become the almoner of the poor, and listen to the petitions of the stranger-in this way, he is rolieved of much that he receives. $\quad * \quad * \quad * \quad * \quad * \quad *$ 
In youth and inexperience, I begun my early labors in the South, and here they will, in all human probability, terminate. I came among you with a constitution unacclimated, and remained with you through seasons when the pestilence was making fearful devastation among our people, especially among the poor strangers that were within our gates. In my performance of duty to them during these seasons of suffering. of sorrow, and of death, you will, I am convinced, exempt me- from the charge of unfaithfulness.

I have been so fully identified with my people. that my mind recognizes no other home but this; for the home of my youth has become to me the house of the stranger.

I have spent with yoou, a long life of anxious labor and of pleasant duty. My people, now to the fourth generation, have ever lived with me in peace and love; they have confided in me as a friend, a Pastor, and a father-and so may it be until this connection is severed by the hand of death-and not even then severed forever. There is a chain which reaches from earth to heaven, and is fastened to the throne of God. Our holy religion gives to the Christian heart assurances of recognition, of reunion, of immortality, and of bliss at God's right hand forever, where all we have lost on earth, will be restored to us again ; where the mind will be $\epsilon$ nlarged, the heart purified, and our capacity for enjoyment adapted to the angelic state.

The sermon closed with an earnest appeal to his beloved flock.

$\mathrm{O}$ could my voice only penetrate the hearts of all my hearers-could they be induced with prayer and labor to aid me in all the benevolent institu- 
tions of the Church, and to let one united voice go up to heaven, "We will serve the Lord."-then might we look for the outpouring of the Spirit of God, for the blessing of heaven, and the salvation of many souls.

\section{It has been said,}

"We must add the weight of Dr. Bachman's character, and the simplicity of his affections, to the few of his sermons that are preserved to us, in order to understand the charm and power of his appeals. One who sat for years under his ministry said: 'His sermons always moved me.' I have been told that often at meetings of Synod in the country, he preached without manuscript with powerful effect. His voice was strong and sweet, and his style and manner, were indescribably earnest.

"He excelled as a pastor, and this not because he studied the pastoral art; but because he loved his people and really trusted God. Genial, observant, of vast and varied knowledge and experience, among those whom he had known from babyhood,. and on whose life, even their schooling and their business, he had exercised much influence, in ardent sumpathy with their institutions and manner of thought, and keenly appreciative of their daily affection, it is no wonder he was beloved as well as admired. All his words seemed to his people wise. Everything he did was recounted. They were proud of his fame. They were honored by his confidence. Even pain for a moment ceased at the sound of his voice. His tenderness comforted. His prayer seemed more certain to be answered. And the comfortable words of Holy Scripture seemed to get authority from his kind eye and beloved lips.

"Dr. Bachman's power lay not in what he said or did, not in his manner, but in himself. It was the 
man gave the sermon force, and to his kind words a healing virtue. In literary circles, in public places, at a country house, in Synod, he was the centre. It is easy to see, as we read the dry reports of Synods, how much he was respected, how proud all were of him, how fearful of offending him. He must preside at every Synodical Communion, he must take part in every ordination, and what he and his church are doing, was spoken of, as if it were everybody's pride. Lofty in principle, pure of heart, zealous, tender, and simple as a child in his trust in God, John Bachman, by his own fidelity, has made the past and the future of St. John's congregation."*

We have seen, that in his early ministry in a Southern field, he was among the pioneers of the I utheran Church. The battle for the revival of the doctrinal basis of the Lutheran Uhurch had then scarcely begun. He preached few doctrinal sermons. Dr. Bachman's spirit was, eminently progressive. This is apparent, when we remember the part he took in the formation of the Southern General Synod of to-day, whose unmistakable tendency from its infancy was toward confessional, historical Lutheranism.

We can never forget his eager desire for the publication of the Southern Book of Worship-a ritual thoroughly Lutheran in character. We remember his joy when his congregation willingly adopted the new book, in place of the old New York "Hymns and Liturgy." Many can recall, his earnest, per-

*City of Charleston Year Book, Edward T. Horn, D. D. 
suasive words, recommending its adoption by the whole Southern Church.

In his old age, perhaps, the strongest desire of his heart, was that all English-speaking Lutherans should have a Common Service. We find him suggesting and urging the same, and when prevented by age and feebleness from attending the General Synod that met at Winchester, Va., in 1870, expressing to his brethren, by letter, the burden of his heart's desire-uniformity in Books of Worship-in other words, a Common Service for the whole Church.

The Pastor of St. John's was broad in his Christian charity. Dr. Summers records: "When in England, Dr. Bachman visited the Oxford divines, Pusey, Newman, and others, and, on his return, spoke of them as learned, well-meaning, though misguided men."

His Lutheranism was sturdy and uncompromising. The anxious bench, etc., found no favor in his eyes. On one occasion when a revival of religion stirred the hearts of the community of Charleston, Dr. Bachman decided to open his Church for a short, daily service. He asked no assistance from his brother ministers. The services were continued for a week; the attendance was large; but there was no undue excitement. Before the close of the week, a few over-zealous members suggested a mourner's bench, but Dr. Bachman declined to comply, on the ground that such an institution would not be in ac. cordance with Lutheran teaching and usage, which 
relied on the Sacrament of Baptism, catechetical instruction, the rite of Confirmation and the Holy Communion as all-sufficient. He mildly suggested that if his friends considered a different mode of administration absolutely necessary, they must seek it in another communion. A few, following his suggestion, united with another denomination, where the "anxious bench" was in use. When the husband of a valued member of his congregation, who had not been baptized in his infancy, desired to receive at his hands baptism by immersion, saying that the mode by sprinkling did not meet his views, Dr. Bachman, on the same ground, advised him to unite with the Baptists-which he did; but often accompanied his wife to the Lutheran Church.

From 1858 to 1861 , we find many. letters in the handwriting of Dr. Bachman addressed to J. A. Brown, D. D., of Reading, Pa.

In 1858, Theophilus Stork, D. D., was elected President of Nerberry College, S. C., and J. A. Brown, D: D., Professor of Theology. Both responded favorably and were duly installed in 1859 .

The Inaugural Addresses of the President and the Professor of Theology were greatly; admired, and ordered by Synod to be published.

To Dr. Brown :

DeCEMBer 23rd, 1859.

"I corrected, last evening, the revised sheets of your Address, which I consider very excellent, and 
creditable to your learning and abilities. I regret much that Dr. Stork would not consent to have his printed.

Cannot you. come for a week to see us all? It would be most gratifying to me and my family. I should like to have the College and the Professors represented here, and it would be a benefit to our institutions.

Affectionate remembrance to Mrs. B. and the children.

* * * *

\section{CharLífton, January, 1860.}

I returned, last evening, from a short excursion into the country, where the Doctor supposed I would find better physic than the nostrums in his shop. The change has benefited me, and I have no longer fevers at night, and only occasional paroxysms of coughing.

I found your obliging letter waiting for me. I feel sensibly your willingness to come to my assistance during my indisposition; but I am once more able, as far as poor preaching is concerned, to attend to my own duties. I shall have my hands full on Sunday next (Communion day). The College lies heaviest on my mind. I have not, however, the slightest idea of failure-we must all work and hope. I am willing even to enter the field myself.

For months past I have been greatly troubled about our political embarrassments.

In other days I was a Union man. I am so still; but I go with those who insist on the rights guaranteed to us by the Constitution. Recently, several conservative politicians have visited Charleston. I have not met with them, for I avoid caucuses; but I hear that they feel convinced that there will be no dissolution of the Union-I trust that it may be so. I 
have an abiding faith in that kind Providence that governs nations, as well as individuals.

When you can be spared to come and help us to procure funds, send me a line, and I shall meet you at the station. ***

The College flourished. $\$ 1,400$ were subscribed for scholarships. Dr. Bachman wrote rejoicingly, "students are still flocking in."

In 1860, Dr. Stork resigned the Presidency of Newberry College, and Dr. Brown was elected his successor. In 1861, Dr. Brown also resigned. 


\section{CHAPTER XXIV.}

The Beginning of the War.

COLORED CONGREgation-His DEFENCE-OLD PLENTY-BOSTON DRAYTON-BISHOP PAYNE-JEHU JONES-SERMON ON DUTY of tile Cirristian to IIS COUNTRY-THE ordinance OF SECESSION-IJETTER TO EDMUND RUFFIN-TAKES HOSTITAL STORES TO VIRGINIA-A COMFORTER TO HIS GRANDSONMEASLES - UNEXPECTED VISITORS - BREAD CAST ON TH WATERS-FOUND INSENSIBLE-ST. JOHN'S CHURCH CLOSED.

IN 1860, Dr. Bachman's pastorate in Charleston 1 had extended over forty-five years, and the congregation under his charge was at the zenith of its prosperity.

The Minutes for that year record 560 communicants-370 white and 190 black.

Sunday-school for the whites: Teachers, 20 ; pupils, 120.

For the blacks : Teachers, 32 ; pupils, 150.

The two-story lecture-room, built in 1831, was especially adapted for the use of two schools. The upper story was occupied by the white school, and the basement by the colored.

Dr. Bachman's laborious and successful work among the negroes of his adopted city has been, perhaps, overlooked or overshadowed by his achievements in other directions.

In this field his power as an organizer, was 
brought into full play. He selected his "Laaders" from the most intelligent and reliable of those whom he had carefully instructed-some of these were freedmen. It was the duty of the leaders to visit the sick and report to the Pastor such cases as needed his special care. They generally performed also the burial services for the dead of their own race. The leaders settled all disputes; but if their decision was not accepted, the case was brought before the Pastor. On the appointed evening, the Pastor's study was the little Court-room, and he the Judge supreme. His quick apprehension of the points at issue, and his wise and humane decisions, gave him a singular power over the simple minds and hearts of the negro, and his decisions were reverently received as just and final. Their grateful devotion to him for his unwearied care and kindness was almost unbounded.

In 1816, at his request, the North Gallery of St. Johu's Church was appropriated to his colored flock.

Never was there a more orderly congregation. On Communion Sundays the whites received the Sacrament first, and then the blacks. The physical labor of administering to such numbers at length became so great and exhausting to his strength, that the Vestry suggested that the Church should be closed for the whites on the afternoons of Communion Sundays, in order that he might devote these afternoons entirely to his colored congregation.

Some of the whites were present on these occasions. At the request of the leaders the services of 
the organist were dispensed with, and the band, standing in the front aisle, led the singing. There was no silent tongue in the congregation-no bashful hesitancy, the full voices drowning the cracked notes of the older members. A singular and beautiful custom prevailed among these simple worshippers-they reverently bowed after receiving the consecrated bread and wine from the hand of the Minister-doubtless in grateful acknowledgment of the Saviour's gift of Himself.

Born and educated while New York was still a slave-holding State; removing to the South in early manhood, and faithfully laboring there for the temporal and spiritual advancement of the negro, it was not strange that he should not have been in sympathy with the pronounced abolitionist. Lydia, his father's slave, in accordance with her own desire had followed him to Charleston, and nursed his children. When slavery was abolished in the State of New York, he tells us, he offered her freedom; but she preferred to remain in his service. Her two sons he apprenticed to trades that they might earn their own support.

- When the property of Mrs. Bachman's mother, Mrs. Martin, was divided among her children, the slaves, according to custom, selected their owners in the family. One of these, Plenty, entreated Dr. Bachman to take him. Now Plenty, although honest and industrious when sober, sometimes indulged too freely in whiskey. He urged; "Tek me Massa Bachman. I'll plant and tek good ca' ob de 
ga'den." "Yes, Plenty," said the Doctor, "I don't doubt that you will do your best for us when you are sober; but when you are getting over a spree, you will be likely to cut up your plants faster than you raised them." Plenty still promised and pleaded, and finally was installed as head gardener. Alas for human strength! With better intentions, perhaps, than moved the breast of the renowned "Tam O" Shanter," poor Plenty occasionally had a sad fall, succeeded by renewed promises of amendment. Thus the years rolled on and the habit strengthened, until, at length, the poor old fellow writhed under a genuine attack of Mania a potu.

On his recovery, he came rushing into the Doctor's study as if fiends were pursuing him. Trembling, he stainmered out, "Massa Bachman, Plenty nebber, nebber drink one drap moe." " Ah, Plenty, I wish that I could believe that!" Then the poor old man, with many tears, graphically described what he called " medream." The devil, he asserted, had appeared to him-he knew him "by de horns and de tail," and told him that "drunken ole Plenty was his sure, and he would put him in de big fire in de bad place." His faithful Father Confessor, further deepened these wholesome fears by quoting St. Paul's words, "Neither idolaters nor drunkards shall inherit the kingdom of God." Shaking with fear, he cried out, "De debbil nebber, nebber shal git ole Plenty."

Perhaps, after all his terrors and his deep penitence, an angel whispered words of hope and peace to the terror-stricken soul. He never could be 
brought to believe his master's version of " de dream," viz, that the frightful vision was the effect of drink. At any rate, we feel assured that Plenty disappointed the expectations of his "majesty with horns." From that day the old negro sacredly kept his promise to God, for he drank henceforth nothing stronger than coffee, or a mild decoction from the sassafras root, sweetened with molasses, a favorite drink in those days, called "sassafras beer."

Dr. Bachman's well cultivated vegetable garden gave abundant proof of old Plenty's faithfulness; and when he died years later, in great peace, due honors were paid to his memory, by "de wite famly," as he called them, and by his own race.

As early as 1837, we find Dr. Bachman, justly pained by the misrepresentations of a part of the Lutheran Church in the North.

\section{To Rev. J. D.}

I have heard with regret of your remarks before the Hartwick Synod, with regard to your Southern brethren. 'That part of your Constitution, that excludes the slave-holder from your communion. has been sent to me; and as you have no slave-holders with you, it would appear that you have travelled out of the way to denounce the acts of your brethren that are fur removed.

Having always been an advocate for un restrained freedom of thought as well as liberty of speech, I felt no disposition to prevent you from expressing your honest convictions. As your charges, even if true, could not operate unfavorably to my useful- 
ness in this community-beyond which I am little known; and, as no defence of mine would be likely to be of any avail, I was content to sit quietly under the imputations, which a brother of my own faith had seen fit to cast upon me, believing that the providence of God would not permit His Church to sustain an injury from the imperfections of its min-

I have lately been held up in bold relief as "one who luxuriated from the sweat and blood of the slave." My wife brought into my family four of her domesties, who were attached to her from infancy; they are her private property, are still with us, and are, without exception, communicants of the Church. * * * *

I am fully sensible that you believed what, under excited feclings, you have published. The charge of cruelty and luxury, I think, ought to have been withheld, as I hope that I do not indulge in either. I have labored hard, and I hope not without success, to build up our Church in the Southern States. I preach three times every Sunday, and once in the week. I attend to two Sunday-schools and a Bibleclass. My people, at least, will neither accuse me of idleness, nor luxury.

In Dr. Bachman's Synodical address, in 1845, he reports to the Synod of South Carolina, as follows:

An application was recently made to me by Boston Drayton, a colored member of the English Lutheran Church of ('harleston (St. John's), for permission to go to Africa as a missionary of our Church. He had, for some time, been an efficient leader among the colored people of said congregation. His natural talents were respectable, and his education considerably above that of persons of his 
class. I had no reason to doubt of his piety. The vessel in which he was to sail, was to leave before the meeting of the Synod. I felt it my duty, as President of the Synod, to give him such credentials as would render him useful among the benighted nations in the land of his forefathers. How far this mission, voluntarily undertaken by an individual, and supported, in a great measure, by the people of his own color. will be productive of good, must be left to Him who is the ruler of nations, and who is able to convert even the most untoward events into the instruments of great and abiding mercy. We are greatly indebted to the Rev. Benj. Kurtz, and to several of our Northern friends, especially to the former, for their kindness to this young and inexperienced missionary, and for their advice and pecuniary aid.

Dr. Morris tells us *:

"Bishop Payne (colored), now of the Methodist Church, was reared a Lutheran by Dr. Bachman, of Charleston, and studied for awhile at Gettysburg; but there was no field among us, and he was advised to go to the Methodists, among whom he has become quite distinguished."

We find many letters from and with regard to Rev. Jehu Jones, also from Dr. Bachman's colored congregation. He had been a very useful man in his Church as a leader, and might have been so as a preacher at home, where the negro character and pecularities were understood; but he desired to go North. He went and made an effort to raise a congregation in Philadelphia, but failed. Dr. Morris

\footnotetext{
* Fifty years in the Lutheran Ministry.
} 
says "He was rather notorious there." In his letters he entreats to be permitted to return to Charleston, and that Dr. Bachman would get up a petition for the same-this was done, but without success.

We lose sight of Rev. Jehu Jones; he probably left the ministry.

November, 1860 , Dr. Bachman preached a sermon on

The Duty of a Christian to his Country.

One who was present on the occasion wrote:

"Dr. Bachman, of course, avoided the political questions of the day as much as possible. At a time when Secession seemed inevitable he enjoined upon his people firmness, decision and moderation. $\mathrm{He}$ gave excellent advice to the young men, and addressed our colored brethren also. The appeal was solemn, impressive and eloquent. The day was bright and beautiful; the congregation unusually large, and, by a singular coincidence, the Citadel Cadets were present. I never saw a more interested or attentive congregation."

Fragments of this sermon have been preserved. We give a few extracts :

Psalm exxxvii : 5-If Iforget thee, O Jerusulem!

Brethren, I am about to address you on the "Love of Country," which, next to the love of God, is the most sacred duty that the God of nations has enjoined upon man. * * *

In spite of the prostitution of the venerable name of patriotism, there is and ever shall be, a Christian 
patriotism-a great system of duties which man owes to his home, his people and his State, etc.

If our rights had been protected in the Union, we would not desire a political change-the sound is, even at this moment, mournful to my mind. I was born but two years after the Union and may yet outlive it. Our fore-fathers in Convention entered into a solemn compact for mutual defence and protection. On the part of the majority, these pledges have been violated, and a higher law than the Constitution substituted.

According to the principles of our Constitution, the impending Secession should be unattended by a resort to arms. It is better. like Abraham and Lot, to separate when we can no longer live together in peace. Our State is preparing for a peaceful separation. I shall, as in duty bound, until then, pray for the President of the United States, and for God's blessing on the deliberations of Congress.

Young men, let me offer you a few words of fatherly advice. We are linked together for peace or war; for plenty or want ; for glory or shame. I have not a shadow of doubt of your courage; I would place my life in your hands in the midst of a host of enemies.-But any act of rashness on our part, would place us in the wrong. Act not without authority. Remember courage consists in obedience and prudence, as well as loyalty and firmness. Above all, act only in the fear and love of God.

Ever bear in mind that among the duties you owe to your country, is your daily good example. In the political meetings that you may be called upon to attend, you are not to indulge in the bowl of intemperance, in angry and revengeful passions, or neglect of the duties you owe to your own dear families. We feel and know that our cause is just and righteous; but political changes are often times 
of licentiousness and immorality. How awful would be the visitations of heaven, if our youth should become corrupt and careless!

When the people of South Carolina in Convention, December, 1860, passed the Ordinance of Secession, they selected Dr. Bachman to offer the prayer at the opening.

With the majority of the South he still cherished the hope of a peaceful separation-vain hope.

The tirle of war soon flooded the land, bringing to the South poverty and desolation, tears and death. Brave and tender-hearted as a "Soldier of the Cross," the Pastor of St. John's strove to perform his part.

In the words of another:

"Dr. Bachman found employment in the hospitals, but did not intermit his care of the scattered flock. The legends tell of the welcome visit of the beloved pastor to close the eyes of an aged saint at Columbia, or in the little church in that city to confirm some of his young people; of a doubly solemn Confirmation and administration of the Holy Supper in an upper room at Spartaniourg; of Baptism under a great oak at Mar's Bluff."*

To Edmund Ruffin, Esq., of Virginia, two of whose sons had been killed in battle.

Charleston, Nov. 22nd, 1862.

My Dear Friend: Yours of the 17th instant was received this morning; although it is Saturday-my most busy day, I must answer it at once, lest I

*Charleston Year Book, Edward T. Horn, D. D. 
should, by incessant calls, be prevented from attending, as early as I desire, to this duty and sad privilege.

Although the sympathy of your friend cannot benefit you, yet it will show you that you are remembered with respect and veneration, and that ho feels your misfortunes as a blow on his own heart. I pray God to mitigate your sufferings and to bring back peace and prosperity to our distracted and bleeding country.

My family have been in Columbia all the Summer. My daughters would long since have returned home to keep house for me; but I am unwilling to have them leave their mother, whose health is feeble and unequal to the sole charge of my four little granddaughters. My grandson, John Bachman (Haskell) joined a military company during the vacation, and was doing "guard duty" on the city wharves to protect the supplies, etc., daily sent to Fort Sumter. The exposure proved to be too great for his youth-sixteen years. On his return to College he was seized with what was supposed to be rheumatism, but which proved to be a disease of the hip-joint, which we fear is incurable. We sent him to the Springs in Florida; but he has returned not much improved. He is more cheerful however, and is able to walk a-little on crutches.

Nine-tenths of my congregation have removed their families into various parts of the country, and the men are in the army. I inquired of my own mind what more I was capable of doing at my advanced period of life-seventy-three years. I decided to begin my labors in the hospitals of Charleston. During this Summer I have spent seven. hours daily among the sick and wounded. I became an agent for receiving and distributing funds, food, etc., contributed for the support of the hospitals. 
I am personally interested in the Army of Virginia. I signified my willingness to receive contributions for the hospitals there, and finally resolved to take on the car-load of provisions and clothing that I had collected. I left for Virginia, accompanied by two ladies who were in search of a wounded son and a nephew. My cargo was perishable, and we hurried on to Staunton. Here, my cargo was distributed to the various hospitals between that point and Winchester.

I inquired for you in Richmond, but no one could tell me exactly where you were to be found, and we were in haste. My companions were hurrying on to find their wounded relatives. One, we learned, had died on the battle-field, of the other there is hope of recovery. I was equally hurried on my return, and regretted that I could not stop to find you.

I saw my son William, who commands the German Artillery of Charleston, and has passed unscathed through nearly all the terrible battles fought in Virginia. Amid the blood and carnage around him, he seems to have led a charmed life. He has been away from us for eighteen months, and amid our anxieties for his safety, I am cheered with the belief that my beloved son is discharging his duty to his country. His wife has engaged the looms and spinning wheels of the sand-hillers around Columbia, and she has a loom of her own, and is often at the fly shuttle herself.

One of my son's lieutenants, Rudolph Siegling, was struck by the fragments of a shell and pronounced mortally wounded. The army was ordered to cross the Potomac into Maryland; my son remained that night with his wounded lieutenant, and, before joining his command, ordered a coffin to be made for him. Siegling has however, almost miraculously recovered; he was brought home, and I 16 
saw him to-day on erutches walking about. The young man is both brave and talented. He is one of the few men who has read his own obituary. * *

My friend, the Rev. J. B. Davis of Staunton, Virginia, is with me. Two days hence he is to take on for me another car-load of army supplies, then I shall be alone again, and it would be a charity for you to come and keep my company-for here I am, "Monarch of all I survey" - come to me.

Dr. Bachman, in all his letters of this date, alludes to the prolonged illness of his grandson, John IIaskell, which resulted in lameness for life. During these years of extreme suffering, the bond of affection between himself and grandson was daily more firmly riveted. His quick eye saw that the soul, as well as the body of the young sufferer, needed to be healed. Many times during the day he passed through the little gate that led from his vegetable garden into his son-in-law's yard. Eagerly the sick boy watched for his coming. "No one," he said afterwards, "was ever able to draw me out of myself and my sufferings, as grandfather did."

During the Spring of 1862, the hospitals in Charleston, were crowded to overflowing. Measles had broken out among the soldiers on the coast. One day Dr. Bachman announced to his family, that on his rounds in the hospitals he had found two young men from the up-country, whose parents were not unknown to him, ill with measles. He had promised that, if possible, they should be nursed in his own home. At the noment he had not remembered his little grandchildren. In this dilemma, 
Mrs. Bachman suggested that the basement "painting-room" should be used as a chamber. In this room Audubon had painted many of the "Birds of North America," and here the stuffed specimens of animals had been kept, while Dr. Bachman wrote the letter-press of the Quadrupeds of North America. The specimens had long since been presented to the Charleston Museum. The room was empty and the simple preparations for the comfort of the sick were soon made.

With careful nursing both the young men recovered, and the children did not contract the measles.

The Banks of Charleston were, for safety, removed from the city. St. John's Church, had been closed for many months. A shell had passed through the building and injured the organ; and some of the grave-stones were mutilated. One of the Vestry, $\mathrm{Mr}$. Frederick C. Blum, remained at his Pastor's side, and took charge of the church edifice and the grounds.

On the 12th of May, Dr. Bachman accompanied his family to Columbia. Leaving the latter in the hospitable home of Dr. Edward Fisher, he returned to his post of duty in Charleston.

He paid occasional visits to Columbia, and frequently remained over Sunday preaching in Ebenezer Church, Columbia, or at some point near by.

In one of his daily letters to his family he gave a little episode.

Seated alone in the dusk of the evening, the street door bell rang, and his trusty old servant, Tony, 
announced that a dozen or more old men and women-some with babies in their arms-asked to see "the Minister." He went out to them-they wanted a night's lodging. They were the fathers and wives of soldiers on duty on some of the Islands near Charleston. The train that brought them to the city had been delayed, and when they reached the wharf, to their dismay, the last Island boat had already started. The tired coinpany were provisioned, but had not money enough to pay for a night's lodging in the city. Quick at expedients, Dr. Bachman took them all in, gave the women with babies the only comfortable chamber in his househis own-and the rest were easily accommodated. The Pastor evening and morning had prayers with the pilgrims, and finally saw them safely on the deck of the little Island steamboat.

On the 3rd of July, he was expected in Columbia, and his grandchildren stood watching at the gate for his arrival. They had been questioning if the ortho-. dox Fourth of July melon would appear for dessert next day. It was early for melons and the prices. were exorbitant. The elders, therefore, bade the children to remember the cost of the coveted fruit,. and to try to be content without it. When their grandfather drove up to the door, there, in the bottom of the buggy, lay a great ripe watermelon. He had met a countryman selling melons; the man recognized him as his entertainer in Charleston, and presented him with one of his finest. The children shouted with delight! "Remember," said 
grandfather, "this is bread cast upon the waters that has returned to us." "How nice," cried little Minnie, "that it came back to us a watermelon, and notbread."

In the Spring of 1863 , yielding to the solicitations of his family, he permitted them to cheer his solitude in Charleston, from May until July. One day in July, a fragment of a shell passed over his garden and lodged in an out-building near by. Forthwith he decided that his family should again take refuge with his friends in Columbia.

In August, after a laborious day in the hospitals, he was found before the door of one of his parishioners, lying insensible in his buggyperhaps his sagacious old horse had stopped there. He was carried into the house, and tenderly cared for. In haste a physician was summoned, and a telegram sent to Columbia. Mrs. Bachman gathered strength to accompany his daughters to Charleston. Soon he recovered sufficiently to be removed to Columbia. There he rallied quickly, and, in a few weeks, was again in Charleston, ministering to the sick and dying.

In December of this year, we find him again, for a brief season, with his family in Columbia, resting from arduous labors and rejoicing in the happiness of his little grandchildren. As usual, at the children's festival, Christmas verses were prepared for the occasion by Mrs. Bachman:

"Old Santa Claus, a merry wight, Is far away in sorry plight, Compelled to stay in Yankee land, Because his wares are contraband; 
He tried to run the vile blockade, And many desp'rate efforts made, But all in vain, and now he stands, With down-cast eyes and empty hands. A letter then he thinks he'll write, And send it to his friends to-night, To try their little hearts to cheer, With hope for better times next year."

The letter from the Saint was dated : SkedadDLE-Town, Dec. 25th, 1862.

" I'm very sad my children dear ! And on this sheet drop many a tear."

The childrens' Saint however, showed his good will.

" I've ask'd my friend, a fairy sprite, To cater for you all to-night; She's gentle, active, good and kind, And will, to please you, be inclinedI hear that she's been looking round, And many little things has found, Some toys, I think, and nick-nacks, too, And cakes and sweet things not a few. Be merry then, my children dear, For Christmas comes but once a year ; And though you miss your foreign toys, You've friends and more substantial joys."

Great pains and ingenuity had been exercised to provide these trifles. Besides cloth-dolls, etc., a cathedral, with - a steeple made of pop-corn, excited the wonder and admiration of the children.

"I'll tell you what the fairy said,

'Twas made of moonshine in a night, And though it looks so pure and white, Is bound with spiders' gluey webs, Drawn out in slender subtle threads." 
Addressed to Eva:

"Do you believe this fairy tale?

Or must you touch the fabric frail ?

Take care! you know you're rather rough, And fairy-work is never tough."

All were remembered, even the dog, Mac, was bountifully provided with hoe-cake.

"But where is Mac? Pray don't forget

Your Uncle Willie's darling pet,

But save for him, a right good slice

Of hoe-cake and of all that's nice."

The home-loving Pastor of St. John's took part with joy in this family festival and afterwards these simple rhymes were sadly recalled as the last composed by his wife for the amusement of his grandchildren.

In a few days he returned to his lonely labors in Charleston.

To Mrs. J. W. E.

Cha Rlestrun, Sept. 8th, 1863.

My dear, kind Frieud: I seldom go as far into the heart of the city as your residence. The Postoffice and all the hospitals, except the Marine, having been removed up town.

I trudge on foot and only go into the lower part of the city when pressing duties urge, and therefore see less of your pleasant, hospitable home than I did in other and happier days. * * * I return home, mourning over our scattered people. But let us try to submit to our lot-ordered by a Wise Providence, discharge our duty under all circumstances, and look to that Mighty Deliverer, who, out of seeming ill, is yet educing good. *** 
If I had much to do, when you left me, you would pity me now, for my labors since then have more than doubled. I often receive from fifteen to twenty letters per day, and more than one-third require answers. Many of my people are in affliction, and I cannot write them short letters. But somehow God prepares me for my burdens. * * *

I am glad that you are not here to listen to this terrific bombardment. *** I shall not murmureven if Charleston falls. For the liberties of my country, I would cheerfully lay down even my life. Love to all around you.

Your devoted friend and Pastor, J. B. 


\section{CHAPTER XXV.}

\section{DURING THE WAR.}

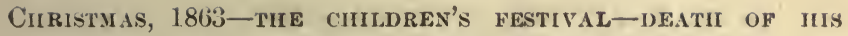
WIFE-VISIT TO CONCORD-LETTERS-CHARLESTON EVACUATED - He LeAYes For COLUMBIA-ENCOUNTERS THE FEDERal IRMY AT CASH'S STATION-CRUEL TREATMENT-RETURN TO CHARLESTON-ST. JOIIN'S RE-OPENED-THE CONGREGATION POOR BUT UNITED-FEEBLENESS AND FAILING EYESIGHT.

CHRISTMAS Eve, 1863, Dr. Bachman joined his family in Columbia.

On Christmas day the Churches were opened as usual. Sad-eyed women and old men listened gladly to the Gospel appointed for the day-the message of "good tidings of great joy." But a heavy weight was resting on Southern hearts and homes, and only the children exchanged the time-honored greeting, "Merry Christmas."

In the home, a little table was spread, adorned with the bright berries from the woods, on which was placed the few home-made gifts prepared by weary hands. We had urged Mrs. Bachman to write her usual shymes for the children, but she could not be induced to do so.

We found later her last written thoughts, traced with a very feeble hand. 


\section{Man's Only Refuge.}

Infirm, desponding and dismayed,

My faith cast down, my hope grown dim,

I seek for light; but human aid

Can shed no light on doubts within.

Around my path dark shadows fall, And gloomy visions crowd my way,

While clouds, like a funereal pall, Obscure the cheerful light of day.

When foes invade, and dread alarms Are pressing sore on ev'ry side,

E'en life has nearly lost its charms As war rolls on its crimson tide.

Where shall I flee? To whom apply Or look for help? 'To God alone !

For He will hear my humble cry, And raise me to His heav'nly throne.

God's promises were freely giv'n To me, as to the saints of old,

Then, why should I by doubts be driv'n, Or let ny faith and hope grow cold?

Oh teach me, Lord, to watch and pray For light and comfort from above;

'To ask for faith's illuming ray,

To fill me with a Saviour's love.

This can alone the gloom dispel,

Which darkens life at this sad hour, And break the with'ring dreary spell,

Which bends me down with magic pow'r.

In eestacy of faith and love,

All gloom and doubt shall flee away, And angels welcome me above

To realms of everlasting day.

The day after Christmas, Sunday, Dr. Bachman was expected to preach in Columbia, at Ebenezer Church.

Soon after the dawn of day, he summoned a daughter to his chamber, saying her mother had been ill during the night. Without disturbing the 
rest of the family, he brought the Physician. A simple remedy was ordered, Mrs. Bachman, in a clear voice, directing where the medicine could be found. A moment afterwards she intimated her impression that her death was at hand. Before we could take in the thought,

\section{"Angels had welcomed her above,}

To realms of everlasting day."

Tuesday, December 27th, Dr. Rude performed the last sacred rites, and preached a sermon from the words of the Psalmist. "Precions in the sight of the Lord is the death of His saints."

And was not she one of these? Her cheerfulness, her gentleness, her kindness I shall never forget. Precious to me is the remembrance of the hours spent with her. She carried within and about her so much of heaven-the impression was that you held converse with one, who had learned of Him-who walked with him. Our last conversation with her-alas that it was the last! was about the soul's condition after death. Firm was her conviction that pure, unspotted and made perfect, it should dwell with the Saviour. Now she knows, she realizes the truth of the Apostle's declaration. "Eye hath not seen, nor ear heard, nor heart conceived the things, whici God hath prepared for them that love Him."

"Forget her not, serve as she served, love as she loved, live as she lived, that your life may be as useful, as devoted to duty, to Church, to God-that your last hour may be as calm, and as peaceful as her's-for without a pang, without a struggle her spirit past away, and her fellow-pilgrim knew not whether it were sleep or death. 
For you, mourning husband, the goal is not far distant, and when the moment of your departure cometh, blessed thought, we shall again say : "Precious in the sight of the Lord is the death of his saints."

In God's acre adjoining St. John's Church, Charles ton, where her kindred slept, Dr. Bachman could not lay his beloved wife to rest, for the sounds of war, the bursting shell, forbade it. Under these circumstances, the vestry of Ebenezer Church, Columbia met and tendered him for his dead a spot in their Church-yard, and there they reverently laid her body to await the resurrection morn.

When Columbia was burned in 1865, Ebenezer Church was destroyed by fire; but the resting-place of his dead was not disturbed.

Now at her side sleeps his beloved grandson, the late Rev. John Bachman Haskell, Pastor of Ebenezer Church.

Tó his Daughters.

Concond, N. C., Jan 1st, 1864.

My dear Children-You will be glad to know that I arrived here last evening safely, without detention or accident. The rivers were very much swollen. I stopped a night with Dr. Horlbeck at Winnsboro. It rained in torrents all next day. This morning I visited my poor sick and afflicted patient. She is still very beautiful, though she is fast losing ground. She clings to me-I shall devote four days to her. May God sanctify these labors to the good of her immortal soul. 
I am surrounded by dear and sympathizing friends, who do every thing for me that lies in their power; but my heart is sad and solitary. I am using all my efforts to stem the torrent of a grief that unresisted would carry me almost to the brink of despair.

Your dear mother a few nights previous to her death said to me, that you had repaid her a thousand times over for all her attentions to you in childhood. To me you have ever been most dutiful daughters; I could not wish for more attention, obedience and affection; yet the remnant of my life must be solitary - it cannot be otherwise-I submit to God's will. I shall endeavor to live for my children and for my duties. God may have something more for me to do, if it be only to suffer. * $*$ * * * * * * * *

Love to all, not forgetting the little folk,

$$
\text { J. B. }
$$

To Mrs. H. M. T. :

Charleston, Feb. 17th.

My Dear Emma: On my return on Saturday night, after an absence of several weeks, I found your letter of the 2nd instant, together with about fifty others waiting for my attention. I shall notice your's among the first.

I went to the country to visit the sick and to seek relief from my heavy trial-alas! I have not recovered from the shock! My two homes in Charleston and Columbia, are almost insupportable to me, as I am every moment reminded of my irreparable loss and desolate state. I know my duty well enough, and I am daily praying for strength to bear my loss with submission to Him, who orders all things in wisdom. I feel assured that $\mathrm{He}$ will not forsake me, but will be with me during the short time to which my lonely life is now restricted. 
I was absent from Charleston three weeks. In this time I returned once, and remained a day, in order to take a poor young friend to the Asylum in $\mathrm{Co}$ lumbia-she had consented to go, provided that I went with her. I then hastened to Camden, Sumter, Cheraw, Society Hill, Darlington, Mar's Bluff, etc.

I went in part to stir up the people in behalf of our hospitals, and, I think, have been successful. Next, I collected our people together in groups and administered to them the Communion-which was very comforting to all of us.

I occupy and try to direct my mind by attending to many duties, visiting many persons with whom I had corresponded, but whom I had never seen. I was everywhere treated with unbounded and unmerited attention.

I have returned to Charleston in better health; every moment, however, reminds me of the penalty attached to a long life. I have buried my early friends, and am left like a pelican in the wildernessbut I will not distress others with my griefs"Father, not my will, but Thine be done."

My daughter C. has been quite sick, and I have written to her that if she desires it, I shall take her next week to her sister L_-'s, in Greenville.

Bowman has gone to St. Matthew's, and I am to preach in his Church on Sunday next.

I have had staying with me, Mr. M-ll, Mrs. $\mathrm{S} \longrightarrow \mathrm{n}, \mathrm{Miss} \mathrm{H}-\mathrm{S}$; but, alas! I am no company for them-my heart and my thoughts are elsewhere.

I have amused myself in planting my garden. I have spinach, salad, celery, turnips, carrots, rutabaga, beets, etc., on table every day. I have planted Irish potatoes, peas, and most of the Spring vegetables.

Smeltzer left me last evening. Our hospitals 
have greatly improved. I hear of small-pox, but cannot find it. There have been a few deaths from congestive chills. I saw two cases yesterday ; these, I think, will recover.

I yesterday, called on Mrs. M- - ll. I fear that our sad and bloody times affect her unfavorably.

Where is your husband?

Your affectionate friend and Pastor, J. B.

About this time his daughters and granddaughters joined him in Charleston. The following June, (1864), he united in marriage his third daughter, Jane, to his son-in-law, William E. Haskell.

\section{January 20th, '65, he wrote:}

Haskell's bank has removed its agency to Columbia, and he has gone there; when the Greenville road is repaired he expects to remove his wife and children to his brother's in Abbeville, then $\mathrm{C}$. and myself will be quite alone here. * * All of us will trust in God. There is an overruling Providence. God will not forsake us. * * Let us propitiate Him by faith, repentance, obedience, and newness of life, and all will yet be well. We have nothing new here, except harder times. Wood (pine) is $\$ 110$ per cord, etc.

In February, the absent members of his family and congregation urged him to leave Charleston; a son stationed on the coast, wrote, " the city will be evacuated. Seek an asylum elsewhere." The few members of the congregation compelled by circumstances to remain in Charleston, added their earnest entreaties, saying, "You cannot protect us, and it would be foolhardiness for you, who made the 
prayer at the "Secessinn Convention," to stay here." Unwilling to go, he lingered in the city. February 13 th, the last passenger train of cars was to leave. On the morning of the $12 \mathrm{th}$, he called his daughter, C. L. B., the only member of his family in the city, and said to her, "I have yielded. You are not strong enough to be exposed to hardships and, perhaps, insults; we shall leave to-morrow for Columbia."

The hospital stores were hastily distributed. At Noon next day the train started. There was a dense crowd, but space was made in the aisle for Dr. Bachman's seat-his valise. At day-break we reached Cash's Station, near Cheraw. It was bitterly cold. Dr. Bachman proposed to spend the night here and take the early morning's train for Columbia. His hostess, Mrs. Ellerbe, and her son (by a former marriage), Col. Cash, overruled their decision, and the worn-out guests were glad to remain longer in their hospitable home.

A few days later Charleston was evacuated. The Confederates passed over the railroad, destroying the track behind them, and abandoning a car-load of ammunition, etc.

On the morning of the third of March the news came that the Federals were seven miles from Cheraw, and that Columbia had been captured and burned. The negro men quickly disappeared, and Dr. Bachman was the only man to be found in the settlement. The car-load of ammunition had been left not far from a dwelling house occupied by 
refugees from the coast. Fearing lest a match should be applied to the powder, he pressed the negro women into service. They cheerfully assisted. The car, happily, stood on a grade of the road where the rails had not been torn up. A vigorous, united push and away it rolled to a safe distance.

Eight of the most trustworthy negroes from the plantation had been secretly mounted on fine horses. Abundantly provisioned for. a week, they were sent into a densely wooded swamp to take care of the horses, and guard the hidden provisions and trunks. Only a person thoroughly aequainted with that part of the country, could possibly have tracked them. The negroes were well pleased with the trust reposed in them. The approach of the Federal troops was announced by a terrific explosion-they had put a match to the car of ammunition. The negroes, under the impression that their hiding-place was being shelled, in hot haste mounted the horses and rode out. The fine horses were a great prize, and, of course, were captured and eagerly mounted by the Federals.

Tender mercies are seldom exercised by an invading army. Under the false impression that silver and gold were hidden by the family, and that the old man before them knew the spot where it was concealed, the soldiers roughly interrogated him. Upon his denial of the same, they beat him and threw him on the ground. He told them they might shoot him, but begged that they would not " bruise and batter a defenceless, unarmed old man." 
With a heavy sheathed sword one of them struck him several times on his left arm near the shoulder, causing great agony. The account of the cruel treatment received, has been preserved in his own words.* But why harrow the reader by further details? We would rather bury the past, and spread over it the mantle of charity.

Amidst pathetic scenes, the ludicrous side of the picture was not entirely wanting. When the trunks were to be sent into the woods, by close packing, one was left empty. Dr. Bachman had received a present of a pair of new shoes, which he needed greatly and valued in proportion. These he determined should not be sent away-yet if he wore them, they would most likely be taken from him. He decided to leave them in the otherwise empty, open trunk, beneath the tray. The trunk was kicked about by the soldiers, and, to his intense satisfaction, pronounced by them empty, and the new shoes were saved.

Early the next morning (Sunday, March 5th), Dr. Bachman held a short religious service with the family. Soon after the large smoke-house near Mrs. Ellerbe's kitchen was set on fire by the soldiers. The providential direction of the wind and a supply of wet blankets, saved both the kitchen and the family mansion.

While the smoke was wreathing over the smokehouse, a tree took fire, and our attention was at-

* The Rise and Fall of the Contederate Government, by Jefferson Davis. 
tracted to a squirrel that jumped frantically from limb to limb. When the burning tree toppled over and fell, the mystery was solved. It was the mother-instinct - a nest was found containing the charred remains of tiny squirrels.

When the army had moved on, a wagon arrived, containing provisions and even medicines, sent by a member of the family whose plantation was not in the route laid waste. The loaves of wheat bread were a special luxury.

Dr. Bachman was urged to remain, and lingered here for many days. In April he received a letter from a member of his congregation (R. G. C.), at Mars Bluff, S. C., who wrote:

"Come to us and baptize my baby, and, after awhile, we can take you with us by wagon to Columbia."

There were few clothes left to be packed up, and, besides Confederate money, Dr. B. owned but one small coin. At the Railroad station he was recognized by an official on the road, who said, "Get aboard, you are entitled to a free ride." A poor country woman stood on the platform with six eggs in a little basket, "I have no money," she said, "will you take my eggs and carry me to see my sick daughter?" The quick response was: "Jump in, Granny, and take your eggs as a present to your sick daughter."

He met at Florence some Federal prisoners on their way to Sumter. They were the men suspected of having committed the outrage on his person; 
but he gave neither sign nor clue, by which thercould be identified.

There were no traces at "Mars Bluff" of a bloody war; but the hearts of all were sorely anxious. Most of the railroads had been destroyed, families were separated without the means of communication, and rumors of disaster and death were rife.

During these days of bitter suspense, Dr. Bachman's devices to keep up his spirits were pathetic. He taught a class of young people Botany; the preparation for the lesson and the drive to the place of meeting, Dr. G.'s, proved a happy diversion from brooding thought.

On Sunday afternoons he preached to the negroes. We find in a note book, this entry:

Sunday, May 7th. Dr. Bachman preached on the Ten Commandments. The negroes attended from all the neighboring plantations and formed a large and attentive congregation. At the close of the services, one of the women, from Gen. Harllee's plantation, brought a pair of socks that she had knitted for him-the offering of an humble heart grateful for religious instruction.

In April, Gen. Lee's army-the last hope of the Southern Confederacy, surrendered.

Dr. Bachman had sought but failed to communicate, by private hand, with the scattered members of his family. At length the oppressive silence was broken. Letters reached him containing assurances that all his immediate family were safe. Rumor asserted that a fire had laid waste a large portion 
of Charleston. Had he no longer a shelter there for his family? A letter from a member of his congregation relieved his mind on this head; but informed him that taxes were to be paid on his house. About the same time a letter was received from the widow of Audubon containing a gift or a loan of fifty dollars. A year later, he was able to refund the amount; but the value of the timely assistance could never be measured or repaid.

The Pastor of St. John's soon made his way to Charleston. June 11th, his Church was opened and his little flock gathered around him, with tears and blessings. On this occasion the Communion was administered.

By September, many of the refuges had returned to Charleston. We find this record-

Sunday, September 17th. Forty-two were added to the membership of St. John's, the candidates for confirmation occupying eight pews. Pastor and people were greatly encouraged. He wrote:

October 29th. "I am still endeavoring, although with declining strength, to preach to my people. They supported me liberally when they were able, now we are all poor together, and I am sharing their poverty.

Haskell expects to return to Charleston next week. I shall live with him in my own house: I believe with old Stilling- " The Lord will provide." I am now in my seventy-sixth year, and it cannot be long before my Heavenly Father shall call me home. I hope to be faithful to my God and Saviour. I have no merit of my own and lean on Him who is mighty to save. 
God has visited my people with His grace. Fortytwo were added to the Church lately, and twentyfive are preparing to unite with us before next Easter.

'To Mrs. Emily E., a membek of St. John's.

I wish that your dear family had been left to solace me in my age and sorrow. True I am not without a hope that we shall meet again even in this uncertain world. If not, I trust that we shall be prepared, through the mercy of a Saviour, to dwell together in a land where there are no partings. If the half hour spent with you-all that I had to. spare in the midst of many pressing engagements. was so delightful, how joyful it will be when we meet to spend an eternity of bliss at God's right. hand.

I sometimes detect in myself a secret wish that the journey was ended; but then, I call to mind that He who placed me here, has alone the right to recall me, and I try to be governed by His will and say, " not my will but Thine be done."

In our congregation the chronic cases remain about the same. Others are very low: Mr. C. is dying of dropsy ; he is still much troubled in mind, I see him every day. I have a group of new cases out of the congregation, that you are not acquainted with-I am of course, very busy.

Remember me kindly to your good husband. I had hoped long before this, to have laid my hand upon his head, but we must still live in hope and prayer. Perhaps when he goes into the fields to meditate, like the patriarch, he may find the Saviour, whom he did not acknowledge in the Church. I pray God to instruct and bless him. * * *

You see I write with a trembling hand, and not 
without pain. You will prize my letters, as they cost an effort.

“At the first meeting of the Vestry of St. John's, the President presented a discouraging account of the injuries which the property had sustained, and the losses of the Church. Much was said of the sorrows that had fallen on the people and of their poverty. A considerable debt, which more prosperous times had disdained to pay, hung over them. It was resolved to take up a collection every Sunday morning-half of it to be given to the support of the Pastor, and half to the expenses of service. After a little while the members began to pay for their pews at half the rate in use formerly, and, in 1866 , the old rates were restored.

It is pleasant to read in the Minute Book the record of the mutual affection of Pastor and people."*

The step of the Pastor was feeble; individual members of his congregation presented him with a horse and buggy, and his heart overflowed with thankfulness. His eyes were to him "the thom in the flesh; the trouble steadily increased, and in 1868, the need of an Assistant in the Church became apparent to Pastor and people.

* Rev. Edward T. Horn, D. D., Charleston Year Book. 


\section{CHAPTER XXVI.}

\section{A F TER THE W A R.}

An ASSISTANT PASTOR ENGAGED-ADNRESS ON HUMBOLDT-FIFTYFIFTH ANNIVERSARY SERMON-REV. W. W. HICKS ELECTED CO-PASTOR-PROPOSED ENLARGEMENT OF ST. JOHN'S-OPPOSITION-THE SCHEME ABANDONED-RESIGNATION OF CO-PASTOR ACCEPTED-REV. JOHN H. HONOUR ELECTED ASSOCIATE PASTOR-FRUIT AFTER MANY DAYS-A GRANDSON STCDIES FOR THE MINISTRY.

TANUARY,1869, a committee was appointed to confer with Dr. Bachman with regard to an assistant for St. John's. Just at that time Rev. W. W. Hicks, of the Dutch Reformed Church, arrived in Charleston, and was introduced to the Pastor of St. John's. The former visited him and spent hours in his study. His impressive reading of the Bible toucher the Doctor's heart. Mr. Hicks signified his willingness to serve him as an assistant, and expressed a desire to leave the Dutch Reformed Church and to join the Lutheran. He was engaged for six months.

On the 14th of September, 1869, the centennial anniversary of the birth of Humboldt occurred. Dr. Bachman's German fellow-citizens urged him, on the ground of his personal acquaintance with the great scientist, to prepare an address for the occasion. Although he hesitated at first, his heart. 
warmed as he thought over the subject, and he dictated to his amanuensis with his usual freedom.

'The address is remarkable for its freshness, written, as it was, in the eightieth year of his age, when he was too feeble to deliver it himself.

We give it in full, as it appeared in the Charleston Courier :

\section{HUMBOLDT.}

Having been honored with a request from the German Societies of Charleston to join in the celebration of an event which recalls to the mind not only of the German, but to the man of science in every land, the name, character, and eminent usefulness of one of the greatest men in the natural sciences which the world has ever produced, I feel at a loss to decide where I am to begin, or which of the numerous subjects presented in the eventful life of Humboldt it would be most interesting to dwell upon.

I have thought that you might be most interested in a few of the reminiscences of my early intercourse with that great man, who, even at my first acquaintance with him, appeared among the naturalists and philosophers, as a giant among a race of pigmies. We delight to trace the history of a great mind, who climbed far beyond the footprints which his predecessors had left, and, from this still eminence, listened to the harmony of the universe, and repeated its music to a listening world. He whose life and history are called to our remembrance to-day, has left a name, so worldrenowned, that, until now, none have equaled it. "That name echoes from the peak of 'Teneriffe, the summits of Chimborazo, and the gigantic ranges of 
the Himalayas. Where science, from her mountain throne, contemplates the vast monuments on which time has recorded the history of the world, or, unfolding the bosom of the earth, reveals the record of the successive phases of its development; wherever the tides of ocean, the rush of mighty rivers, and the stillness of unbounded plains, proclaim the laws which make this globe a habitable world-wherever forests wave, decked with exuberant foliage, laden with many hued and fragrant flowers, and fruits of luscious taste, and teeming with throngs of beasts, birds and insects-throughout nature's richest kingdoms, the name of Humboldt stands confessed-the greatest of nature's historians, the wisest and most eloquent expounder of her laws."*

It was in the latter part of the summer of 1804 , that I was permitted, for the first time to look upon the countenance, to press the hand, and listen to the interesting words of this great philosopher. He had arrived in Philadelphia, with his associate, Bonpland, after having explored almost every portion of Mexico, and measured the heights of the Cordilleras, and Chimborazo. He had visited portions of South America, which had not been reached by previous travellers, he had remained in Havana for ten months, where he completed his political essay on Cuba, and after a five years residence in America, he was now about to return to Europe. Efforts were made to evince the respect of the community for such a successful traveller, and so eminent a naturalist. Attempts were made to collect together the few who had any pretensions to natural science, residing in Philadelphia. I was then a student, and only sixteen years of age, but it being

*Humboldt's Leben, von Herman Klouke. 
known that I was occasionally in the habit of accompanying Wilson in his researches in Ornithology, and of spending my vacations and Saturdays in Bartram's garden, the usual resort of botanists, I was honored with an invitation to meet those who were about to welcome this eminent philosopher and naturalist $t_{1}$ ) our country. I felt that I was not deserving of the high honor of the invitation, and mention the fact here, to show how scanty, in those days, were the material in natural science. A dinner had been prepared for the occasion in Peal's Museum. Among the few naturalists who attended were the two Bartrams, Wilson, the Ornithologist, Lawson, his engraver, George Ord, and a few others, whose names have now escaped my recollection. To this small group was added a considerable number of men who were eminent in the various departments of literature and science. Few speeches were made, and those were short-there was no formality. Humboldt was then, as he was afterwards, in every society, "the observed of all observers," ready to answer any question that was propounded to him, and evidencing throughout a spirit of gentleness and kindness, and great amiability of character. I saw him every day during the few days he remained in Philadelphia. He inserted my name in his note-book, and for the last sixty years we corresponded at long intervals. His publications, as they successively appeared, mostly in the French language, with the exception of his "Aspects of Nature," which was in German, were regularly sent to me. It would have been very gratifying to me, and interesting to your societies, if I could have exhibited to you his autograph in some of his letters; but, alas! my wholelibrary and all my collections in Natural History, the accumulation of the labors of a long life, were burnt by 
Sherman's vandal army, and, with the exception of a single letter, which, by accident, fell into the hands of another member of my family, I possess no memorials of one who condescended to speak of me as a friend.

Thirty-four years passed away, and I was once more permitted to renew a personal intercourse which had so long been interrupted. Arriving in Berlin, he was the first to welcome me, and to extend those civilities which enabled me to feel myself at home among the men of learning and science in my fatherland. Although years had passed away, time had wrought but very little change in his countenance, or in his habits. He was the same cheerful, pleasant companion, the same indefatigable student, giving but four hours to sleep, and laboring in his studies with uninterrupted zeal.

When about to separate, we arranged to renew our intercourse again at the Association of Naturalists, who were to meet that year at Freyburg in the Duchy of Baden, where were to be congregated the most eminent Naturalists of Europe. The members all dined at a common table, but our breakfast and tea were served up in private apartments. An opportunity was thus afforded us for private intercourse and conversation with friends. We made arrangements to welcome Humboldt into the small group who breakfasted and took tea together. A few of the eminent Naturalists of Europe composed our little party. Professor Buckland, of Oxford, was there, and his lady presided at our cheerful board. Professor Owen, of England, assisted in forming the party. But we were doomed to disappointment. Humboldt was detained, by order of the King, in Prussia, and wrote to express his regret that he could not be with us.

I never expected to meet him again, but late in 
the Autumn of that year, happening to be in Paris, and attending a meeting of the French Academy, one of the first persons I met, was Humboldt-and for two weeks I saw him nearly every day. He was still, as usual, the student of Nature, gave his hours of repast to a group of friends, who united in conversation with him, and devoted the remainder of the day to the various studies in those sciences to which his life had been devoted. He always spoke of himself as an humble student of Nature, who knew but little, and was struggling to acquire more knowledge.

It was pleasant and somewhat amusing to observe his manner and occupations during the day. At a stated hour in the morning he was to be found at the Garden of Plants engaged in some investigations in Natural History. I met him there with his coat off and in an apron that nearly covered his whole body, engaged in dissecting an animal that had just died in the menagerie. So intent was he upon his labors that he seemed to have scarcely time to turn his head to answer the various questions that were addressed to him. Thus, for some hours, every one appeared to be intensely engaged in his own work. At a certain time of the day, these French philosophers always resolved on an hour of rest and recreation. When that time arrived one of the attendants passed through the rooms of these students of nature, calling aloud, "the hour has come, boys, come out to play!" Instantly the whole scene was changed, the philosophers shut up their books, laid aside their instruments, changed their outward dress in a few moments, and it appeared as if a group of happy children were jumping and frolicking around you. A considerable portion of the garden was devoted to a menagerie of wild animals, and among the most amusing were the 
monkeys, collected from all quarters of the earth. Here these philosophers amused themselves until the dinner hour, and for a time the sciences were all forgotten in the hilarity of the occasion. I noticed that Humboldt exerted himself to be as gay and happy as any in that most interesting group.

The dinner hour arrived, men who wish to render their time in Paris agreeable, usually arranged to dine tegether at some of the tables-d'hôtes, where old associations are renewed, and where they can enjoy, uninterrupted, the most entertaining and delightful conversations. On these occasions I usually met Humboldt. There he was the pleasant and instructive companion, and we all conceived it to be not only a great privilege but a high honor thus to associate with him.

At the meetings of the Academy of Sciences he preferred being a listener. Occasionally, for the purpose of eliciting an opinion, a question was put to him, which he would answer in a few brief words, and then resume his seat.

At night, to the various parties that were given in Paris, Humboldt was always invited, and it appeared that he never declined the invitations. Ladies of the highest rank were not satisfied without an introduction, and they always spoke of the occasion as one of the greatest honors that had ever been conferred upon them.

I would, just here, remark that Humboldt was, in figure, of the medium size, his forehead broad and high, his hands and feet delicately formed, his locks, in the latter part of his life, of silvery whiteness. His eyes were blue, and full of expression. Thirty years ago his features appeared undimmed by age, and whilst enjoying his conversation, in which there was wit and tenderness, you lost for a 
moment, your reverence for the great man, in your admiration for a kind and jovial companion.

He was born at Berlin, 1769-a memorable year in the annals of genius, for in it were born Sir Walter Scott, Cuvier, and Chateaubriand-also, the eminent English orators and statesmen-Canning, Mackintosh, and Brougham. He was of baronial lineage, his father was Chamberlain to Frederick the Great, and a personal and intimate friend of the succeeding king. His father was not gifted with any striking qualities. Humboldt was indebted for the direction of his education to the Baroness, his mother, who was no ordinary woman, and whom he loved and venerated. She was descended from that sturdy race of French Protestants, whom the revocation of the Edict of Nantes scattered abroad, to the advantage of every country where they fixed their abode. This lady appears to have transmitted to her son the cheerfulness, vivacity, and quickness of apprehension, which belonged to her own race, while he inherited from his father the tenacity of purpose, which so much distinguishes the Teutonic character.

Humboldt was peculiarly favored in the possession of every advantage for the acquisition of knowledge. It cannot be said of him that he was ever deprived of any thing that was necessary to render him a great and eminent man. From his earliest years to mature manhood he lacked no instruction which weälth, rank or station could lavish upon him. He was educated at the University of Göttingen. Wherever he went, in his adventurous career, the same cordial welcome and co-operation awaited him. Kings and Governors vied in promoting his progress; lovers and cultivators of science in every country contributed of their own stores to enrich him, and through him, the world. 
How vast those resources were, and how usefully they were employed, may be seen in his works. He lived to a great age. He was born in 1769, and died 1859, having reached the unusual age of ninety years. The whole of his long life was devoted to studies and labors calculated to benefit mankind. His last work, the "Cosmos," is a monument of meditation and research, unequaled in all the labors of science. Even when the weight of fourscore and ten years lay upon his head, he toiled whilst others rested, and it is asserted by those who knew him most intimately, that the morning's dawn often surprised him at his desk.

He had a brother, Karl Wilhelm, two years his senior, who became almost as eminent as himself in many of the sciences.

In the many conversations I had with Humboldt he often alluded to his attachment to the American nation, and spoke of himself as half an American. inasmuch as some of his earliest labors had commenced in America.

He had no time to devote himself to minor points in the sciences. His mind dwelt upon the great laws of nature, comprehending the whole circle of the sciences.

In the knowledge of genera and species, and in the particular sciences, he had many superiors. Thus in the Department of Botany, Linnæus and De Candole were fuller. Cuvier and even Buffon had entered more minutely into the study of the quadrupeds; and other authors who devoted thenselves to the study of the birds, fishes, insects, etc., surpassed him in minute description, but in general knowledge he surpassed them all. It is not to be wondered at that a man who, by his intellectual greatness, towered above the loftiest of his contemporaries, and by his simplicity, gen- 
tleness, affability, and modesty of manner, made even the humblest at home in his society, should have become the admired and honored of all men. In the streets of Berlin, every one seemed to know him, and to love him. Crowds would separate to let him pass, without disturbing the reflections in which he was engaged. I remarked that the two nieces of the king ran up to him in the street to impress a kiss on his cheek, calling him by the endearing name of "Father."

In his ninetieth year, with his faculties yet unimpaired, when all his associates of early life had been removed, and his name had been rendered immortal, he was summoned from the earth, and all that was perishable was committed to the tomb, amid the homage of great scientific bodies, and the solemn reverence and silent tears of the multitude, who had wondered at his wisdom, and loved him. for his virtues.

It is difficult to decide whether he displayed more humility in his greatness, or dignity in his simplicity. He adorned the highest, and graced the humblest position. Having had experience with men of all climes, ranks and characters, he was yet never known to have made an enemy.

In order to form some idea of the various sciences which Humboldt had studied, and of which he had acquired a knowledge above all other men, I refer you to a summary contained in the first volume of his "Cosmos," where it will be seen that there was no study, however deep and abstruse, which his mind did not grasp, and no aspect of nature with which he had not become familiarized.

The lessons taught us in these simple references to the life of a great man, ought not to be overlooked. He who desires to be great, must study to acquire knowlerlge. Humboldt considered every moment 
of time lost, that was not devoted to its acquisition. $\mathrm{He}$ who would be eminent, must preserve his mind pure and elevated, and free from all irregularities, and indulgence in licentiousness. Humboldt's moral character was pure and without a stain. He who desires to hand down his name to posterity among the great and the good, must follow the example of Humboldt, and labor to be an ornament to society and a blessing to mankind.

January, 1870, Dr. Bachman preached his fiftyfifth anniversary sermon. The altar services, in the absence of the Assistant Minister, were conducted by the Rev. John H. Honour. The occasion was naturally invested with unusual interest-more especially to the flock over whom he had presided for more than half a century.

The columns of the Charleston Courier of that date have preserved to us the sermon. We give a few extracts :

Proverbs, 16th Chapter, 31st verse: "The hoary head is a crown of glory, if it be found in the way of righteousness."

My Beloved People-Time is ever on the wingeverything is in a state of progression-the smallest twig gradually swells into the majestic tree. This, in time, grows old, totters, decays, and falls to the ground. The rivulets springing from the fountain mingle their streams and form the broad river, which hurries onward, onward, until it empties itself, and is lost in the mighty ocean. These are emblems of human life. And the wise man gives a true estimate of its shortness-all are hastening to the end of their journey; and if the life of the young is spared, 
the hoary head must come at last; and, if your characters are formed on religious principles, if you are pure, upright, benevolent and pious ; if, in a word, you are found in the way of righteousness, then your hoary head will be to you "a crown of glory," shedding its radiance on all around you.

Your aged pastor, who is now addressing you, perhaps for the last time, has arrived at almost the extreme verge of human life. The Psalmist exclaims - "The days of our years are threescore years and ten, and if by reason of strength they be fourscore years, yet is their strength labor and sorrow, for it is soon cut off, and we fly away." This is an accurate description of man's fleeting life. Seventy years are accounted by the inspired Psalmist as the age to which man, under favorable circumstances, may attain ; if, however, by reason of a good constitution and God's especial aid, he should reach eighty years, the period has then arrived when his strength shall soon be cut off, and his soul severed from the body. As music from the string ascends, so it mounts upwards to a home of immortality and joy.

It is by the permission of an All-Wise Providence, that I have presided over this congregation during the long period of fifty-five years to-day, and in three weeks I shall have entered upon the eighty-first year of my life. I stand not here to-day to repeat the history of other days - of the prosperity and adversity through which we have passed-hand in hand. I only intend to draw some lessons of moral improvement from our long connection.

First let us consider the manner in which we shall be called to an account before God, our Judge, - the one for the performance of his duty as a teacher of righteousness, and the other as a hearer of God's Word. The minister has this solemn warning before him, "Son of man, I have made thee a 
watchman unto the house of Israel." "When I say unto the wicked thou shalt surely die, and thou givest him not warning, the wicked man shall die in his iniquity, but his blood will I require at thine hard. But if thou warn the wicked and he turn not from his wickedness, he shall die in his iniquity, but thou hast delivered. thy soul." You perceive then, my dear brethren, how solemn, how awful are our responsibilities.

Think not, my dear friends, that your Pastor, who has endeavored to discharge his duty, however imperfectly, to your forefathers, to your fathers and to you, has been actuated by personal feelings against you when he spoke of your neglect of duty, or desired to find favor in your sight by palliating your short comings. You have heard his authority for the reproof of your errors, and his encouragement for leading you in the path of truth and of duty.

Young man, young woman, as yet you have only been permitted to pluck the blossoms of Spring, still you have been long enough in this garden of the world to learn to discriminate between the pure, the fragrant, and the wholesome, and that which is poisonous and malevolent.

Ye middle aged, have ye not heard the oft-repeated assurances of the punishments that will be reaped by sin, and the rewards secured by integrity, uprightness and piety. Ye aged, have ye not had time enough in your probation, to learn that the hoary head is a croum of glory-but only if it be found in the way of righteousness.

I desire most earnestly to see the work of grace abounding in the hearts and lives of my people. Often and often, for many years past, has the Spirit of God visited us-very recently some who had waited long, surrendered their hearts to God. One who had resolved to be among us was cut down suddenly before the opportunity was afforded him 
to dedicate himself to God; the Almighty, no doubt, accepted the will for the deed. And many others are before me, who have long, very long, been the subjects not alone of the prayers of their aged Pastor. but of their wives, their children, their brothers, their sisters, and friends. Come, beloved brethren, hear my instructions and pleadings, let not my words fall unheeded on your ears. He who has so long esteemed you as friends, who has partaken so often of your hospitality, who united you in the holy bonds of marriage - who baptized your little children - who participated in your joys, and mourned with you in your sorrows, comes to you now-in the last days of his life, with the earnest entreaty, the fervent praver, "Be ye reconciled to God." You believe in the doctrine of the resurrection; you desire that the tender associations commenced in life, may be perpetuated in heaven. Come, take one step more, and God will do the rest. Make a profession of religion, come with all your imperfections to a throne of grace and mercy, and He who said to the penitent of old, "Thy sins are forgiven thee, go and sin no more," will take you under His paternal protection and training, and fit you for that kingdom which is eternal in the heavens. At our next Communion at Easter, we hope and pray that you will be among the many who will dedicate themselves to the service of the living God. O ! delay not, delay not, my sun of life is rapidly going. down, and the hands that now invite you, and are now ready to bless you, are trembling with fourscore years. Oh! what joy, what thankfulness will be created in my aged heart, if those to whose forefathers I have ministered, and for whose descendants I am now spending my latest breath, should with one accord bring the offerings of their hearts to the altar of the living God. 
Brethren, take the best wishes, the fervent prayers and the heartfelt blessing of your aged father and Pastor. May your children be trained up to the fear of God and in the nurture and admonition of the Lord. May the young before me, crowd around this altar to receive the blessing of their Heavenly Father, may husbands and wives draw nigh to this Table of the Lord with devoted affection in their hearts towards each other and towards their God, and may these, my aged friends, who are tottering on the brink of the grave, now give evidence that they have a well grounded hope for their anticipations of a reunion with their beloved beyond the grave. And may God have mercy upon us all.-Soon-very soon, if we walk faithfully with Him, will earth's tears all be wiped away and the wailings of sorrow be swallowed up in the songs of joy and rejoicing; chill poverty soon shall be felt no more, but in the mansions above-within the pearly gates, light and peace and joy will abound throughout the ages of immortality. Amen.

This was the last time that the aged Pastor of St. John's occupied his pulpit-his work as a preacher was ended; but his pastoral labors were still abundant.

Meanwhile the seductive eloquence of the sermons of the assistant charmed the congregation and Dr. Bachman, with joy, threw the whole weight of his influence in his favor. When the Synod of South Carolina convened, Mr. Hicks was received into the Lutheran ministry, and was forthwith elected copastor of St. John's.

The pews and even the aisles of the Church were crowded. About this time, Dr. Bachman sent a 
letter to his Vestry, suggesting that the Church should be enlarged by extending it thirty feet at the east end. In his letter he gives his reasons for the same. "This would be -in accordance with the original plan." "The addition would accommodate a sufficient congregation to give the means of support for two ministers without putting a burden on the pew-holders."

There was one great difficulty in the way-the space that would be covered by the proposed extension was, in part, occupied by graves. It was suggested that commemorative slabs should be placed in the walls of the Church, or, if preferred, the dead were to be removed to "Magnolia Cemetery"-the Church to bear all expenses.

The congregation met and the question of enlargement was warmly discussed and decided upon, by a vote of twenty-one ayes to seventeen nays.

The minority were, however, greatly dissatisfied, and the matter was referred to Chancellor Dunkin, who returned answer, "That while the congregation had the right to extend the church building over the burial lots in question, the monuments could not be disturbed without the consent of their owners." A meeting of the congregation was forthwith called and the subject was fully reconsidered; A few of the most enthusiastic proposed to procure an eligible site for a new building; to pull down the present church, and to use the material in the erection of a larger edifice; but this suggestion met: 
with few advocates. A resolution was finally adopted abandoning the whole scheme.

Soon after this, against the better judgment of Dr. Bachman, the associate Pastor became the Editor of "The XIX Century," a literary journal in which politics were also discussed. A bitter political debate arose between "The XIX Century," and the press of Charleston. At this time, South Carolina was under the misrule of Governor Scott, and the community were greatly excited. Dr. Bachman, in a letter to his Vestry, August 19th, 1870, wrote: "I did what I could to put a stop to the dispute which. had arisen from the controversy. I felt it my duty as a Minister of the Church to do all in my power to check the further progress of the political quarrel."

The Associate Pastor sent in his resignation, August 23rd, and it was accepted.

The Pastor, Vestry and congregation acted with admirable promptitude and decision. The ensuing week a letter was sent to the Rev. J. H Honour, inviting him to become associate Pastor of St. John's. Although he declined to accept, yet he kindly consented to preach to the congregation every Sunday morning until a co-pastor should be elected. This arrangement was continued for eighteen months. The Sunday-school held its session in the afternoons. On Sunday mornings, the venerable Dr. Bachman occupied a seat in the Church, offered a short prayer, and gave the blessing to the congregation.

Towards the close of 1870 , he often complained of a numbness in his left arm, and his physicians 
suspected that what appeared, at first, to be simply vertigo, was in reality, incipient paralysis. $\mathrm{He}$ made, however, his usual round of visits, and even went to Summerville on parochial duty.

An ill member of his congregation, Miss L. P., in search of health, had been received in the home of Charles S. Vedder, D. D., (now Pastor of the Huguenot Church, in Charleston). Warm-hearted, intelligent, cultivated and an earnest seeker after truth, she won the love of Pastor and friends.

Doubts with regard to the doctrine of the Trinity, deterred her from uniting with the Church. Happily she was in the home of a minister, to whom she could freely open her heart. As her health daily declined, her soul craved for a closer communion with her Lord.

One morning, at dawn of day, a messenger in haste, brought a letter from Dr. Vedder, explaining, in a few words, that the attendant physician pronounced Miss P., near her end; that she earnestly desired to receive the Holy Sacrament, and entreated her old pastor to come to her.

The evening train from Summerville to Charleston had already left, and in order that Dr. B. might take the next morning's train, $6 \mathrm{~A}$. M., the messenger had ridden twenty miles, at night, on horseback.

Dr. B. reached his destination, and found his dying parishioner eagerly expecting him. When he had laid his hand upon her head and consecrated her in life and death to the Triune God, and when 
she had partaken of the body and blood of her Lord, a holy calm possessed her soul, and, contrary to the expectation of her physician, she lingered on earth for several days. She was able to converse and to tell him of the kindly ministry of Dr. V. "I am not ungrateful to him," she said, "for his great kindness and patience in instructing me; but when the light broke into my soul, I felt that from early childhood I had been carefully taught, and I craved to see you once more, to tell you that the good seed you had faithfully sown, is the germ of my new life." (The writer was present and witnessed this touching scene).

About this time, to the great joy of the Patriarch, his eldest grandson, John B. Haskell, decided to study for the ministry. 


\section{CHAPTER XXVII.}

\section{Illuness ANd Convalesence.}

LETTER FROM J. A. BROWN, D. D, AND DR. BACHMAN'S REPLYFRUM REV. J. B. HASKELL-REPLY TO LETTERS FROM MILESTOWN, PA.-CORRESPONDENCE BETWEEN JOHN HASKELL AND HIS GRANDFATHER-LETTERS TO A. R. RUDE, D. D., MR. JOHN S. FAKE, REV. T. W. DOSH-BEREAVEMENT-DECLINE.

JUNE, 1871, Dr. Bachman had a severe stroke of paralysis, that for days threatened to terminate fatally : he longed to depart; but, as he once wrote"God had still something for him to do, if it were only to suffer."

Many were the prayers offered by ministers of his own and other denominations, and many the hymns sung at his bedside.

His grandson, John Haskell, has preserved in writing - what he treasured in his heart-the words of faith and trust that fell from the lips of his grandfather.

The columns of the Lutheran Visitor, kept the Church informed of Dr. Bachman's condition, and the daily mails brought letters of inquiry and sympathy from his brethren in the Ministry.

We select one from the late J. A. Brown, D. D.

Gettrysburg, PA., Aug. 14th, 1871.

My venerated friend and father in Christ: The dark chasm of ten years often disappears and reveals 
to me the cherished scenes and memories of our brief association in the South. Since the return of peace, I have, times out of number, thought of writing to you. A letter in the "Lutheran Visitor" has touched my heart anew, and I cannot resist the impulse to drop you a line before you depart where I hope "we shall meet in the sweet by and by."

The uppermost feeling in writing, is to assure you of my undiminished regard and of tenderest affection, which no change of circumstances or lapse of time can or will disturb. Your kindness to me and mine, will never be forgotten-you live in all our memories.

I do not know that I can write anything that will be of special interest to you.

If it will be any satisfaction to receive the hearty assurance of our warmest affection, with the hope of our meeting beyond the turmoils of life, you have it; at least it will be some little satisfaction to me to convey to you the evidence of my devoted friendship.

It would be presumption for me to say anything about your "blessed hope" or "the house of many mansions." I would be glad to learn something from one who has so long walked "by faith" and is now so near "the rest that remaineth." I can only say "henceforth there is laid up a crown of righteousness."

I will not dwell on the memories of the pasteither those which are bright, or those which are dark and sad. Our motto must be: "forgetting the things which are behind." I think of you only as my venerated friend and father in Christ.

We are all well, trying to do something for our beloved Church. Mrs. B. still thinks and speaks of you with a daughter's affection. God has been gracious to us-we are eight, with parents, ten. If 
able, I shall be glad of a line from you, if not, with rod's blessing, good-by, until we meet.

Yours in Christ,

To J. A. Brows, D. D. :

$$
\text { J. A. B. }
$$

Charleston, Sept. 11th, 1871.

My dear Friend: Age that has given me the hoary head, has weakened my memory, and seems to have left me very little at the close of a long life, but a grateful heart and kind and tender remembrances of mercies and friendships. 'Time has not banished you or your dear wife from my affections, or obliterated from my memory our brief and pleasant association in other years. We are pilgrims hastening to a better land, and we have need of friendships to cheer us on the way. In a very little while we shall have come to the end of our journeymine is nearly reached. I trust to be able to say, "Lord, now lettest thou thy servant depart in peace."and I feel, friend Brown, that a man as conscientious in duty, as I know you to be, will be preparted for an exchange of worlds.

May God bless you and yours to the end. Of this I am sure that on your journey,you will never meet with one who more heartily wishes you prosperity and happiness than

Your friend and father in Christ, J. B.

John Haskell, in his letters and diary gives us glimpses of those days.

To Dr. Rude:

July, 1871.

"I never leave the house now, except to go to school, (he was teaching), and to drive out in the afternoons with grandfather. To-day is Saturday, 
and I can be with him all day. He is doing well gaining a little strength, and is able to drive out every day. Unhappily, in the mornings, we have to contend with him to keep him from going in the hot sun to inquire after the sick. The Doctor, when he was here this morning, spoke plainly to him, and forbade him to expose himself to the heat of the day. He has quietly acquiesced, and I have been reading to him "Audubon's Ornithology."

You write that I am studying. Pastoral Theology in my grandfather's chamber.*' I am glad of it; if: it were allowed me, I should like not only to learn to fight.like old Luther, but also to soothe like Melanchthon.

* * * *

We are looking for you to come to us early next: week. Every day grandfather asks, "When will Rude be here?" he has repeated the question at least six times to-day. Last night he said, "Rude" has as much in his little finger, as six ordinary men have in their whole craniums."

With returning strength the restless craving for work steadily increased. Fortunately, this was in a great measure satisfied by his large correspondence. Receiving and answering letters became the business of his mornings and, probably this preserved the: brightness of his mind. The judgment and the will were often at fault; but the affections and the memory continued singularly strong.

*During Dr. Bachman's pastorate, ten young men from St. John's, were trained for the Holy Ministry:

John G. Schwartz, William D. Strobel, Philip A. Strobel, Stephen A. Mealy, Elias B. Hort, John P. Margart, Thaddeus S. Boinest, Edwin A. Bolles, James P. Ring, John B. Haskell. 
Not long before his illness, he had received letters from Milestown, Pa., which interested him greatly.

While a student of Theology, he had taught a year at Milestown.

We give extracts from two letters in reply to Mrs. Annie de B. M.

Your letter was a great cordial to me, and I feel happy in being permitted to answer it. Writing is no fatigue to me, as I have always willing hands and affectionate hearts to assist me.

Your second letter informed me that nearly all whom I knew and loved in Milestown, have been called away: yet the scenes of my youth are still fresh in my mind and your letters have, in some measure, enabled me to renew the enjoyments of other years, and to look again in thought and memory on the countenances of those who were dear to me in youth. * * * * * * * * * * *

The older I grow the stronger I find my attachments to early friends-A voice from Milestown, has opened a new fountain of thought and pleasure. I have fancied myself again near the old school and along the Milestown road, shaded by immense cherry trees which, I presume, are no longer there.

The little Paradise-the home of your grandparents, which you now occupy - the large and beautiful garden where your grandmother cultivated her Howers, the roomy house where she welcomed her friends, can only be erased from my mind, when memory shall be gone and thoughts of earth have passed away.

The garden was close to the dwelling, and one of the most beautiful I had at that time seen; her tulips, narcissus, anemones, etc., cultivated by her own hand, were full of fragrance and beauty-the 
passion for flowers is contagious, and I found it had extended to several others in the neighborhood. * *

Your grandfather's photograph, which you so kindly sent me, is a very great treasure. ** Oh, how I would prize the photograph of your grandmother, who was so much of a mother to me, when I was far from my own home. I imagine I still see her gentle, quiet face, and hear her sweet welcome. $*$ * * * *

My personal history connected with my visit to Pennsylvania is short, and scarcely worth relating.

I had intended to defray my own expenses while studying for the ministry. I remained at Milestown, I think, a year; at Frankfort, not quite so long, until my studies were so far completed that I ac. cepted a call from three congregations in my native county, Rennsellaer, where I hoped to spend the rest of my days as a country parson.

I have some pleasant reminiscences of the old school house at Milestown (Elwood). It was there that Wilson, the ornithologist, first tried his hand as a pedagogue, and it was there that William Duncan, his nephew, succeeded him. I met them both at Philadelphia, and they advised me to accept the offer made me from Milestown.

The old school house was a large one-story building, that appeared to have been enlargerl from time to time, not simply to accommodate the growing school, but to hold a congregation of worshipers that were collected together there as often as some stray clergyman, of any denomination, happened to visit the neighborhood.

The teachers successively boarded at the house of Mr. Culp, situated a few hundred yards from tho school house. The pupils were of both sexes, and of all sizes and ages. The higher branches, although taught, were not much relished. A small class in 
Latin, one in French, and one in German, were, with great difficulty, kept up during my. short stay. We got up a debating society, which lasted as long as I remained in the neighborhood. I do not remember the names of the teachers in Elwood school, beyond those of Wilson and Duncan.

Wilson visited us occasionally from Philadelphia; and I always joined him on Saturdays in looking for specimens in Ornithology, but without success, until I subsequently reached the Northern part of my own State (New York). W'ilson's nephew, Duncan, although shy and diffident, was rather a superior man-mild, amiable and pious. He spent a week with me among my people in the Northern part of New York, and left with me a drawing, in Indiaink, of the old school house, which had been the scene of so many pleasures and pains.

Sixty years must have effected a great change among those people. Milestown, as far as I can now recollect, then scarcely contained more than twenty houses. I presume by this time, the old York road, as well as that of Germantown, on the other side, is studded with houses and thickly populated.

Whell our young people went to church on Sundays, they either walked to Germantown on the one side, or to Frankfort on the other. There was great simplicity of manners in the neighborhood, and we did not often hear of any act of immorality.

Mr. Culp's house (where I boarded) was not only open to the waggoner and traveller, but was also a weaving establishment, and the pond, not far from. the house, contained a chocolate mill.

There were a few tradesmen; there were small farms around the village, and fruits in small quantities were cultivated; but very little had been done that indicated much improvement. * * *

: The names of persons living in the neighborhood 18 
at that time are tolerably fresh in $\mathrm{my}$ recollection. Your cousins, the 'Thomas's, were my associates; I was most intimate with the mother and the two elder daughters-the second of them a gentle, timid and lovely little creature, died while I was there, and I assisted at her funeral. 'The Leach family, residing some few miles above Milestown, wero my personal friends. Do you remember a family by the name of Peaky? The old mother had caught the infection for plants from your grandmother, and had an enormous Century Plant (Agave) which occupied nearly the whole room. 'I'he Rev. Mr. Tennant and his wife, (Rev. ' $T$ '. was the last of a celebrated family of Presbyterian ministers) I was in the habit of visiting on Sundays and attending the services of the Church with them. We have a small branch of the same family residing here. * * *

My inclination is sufficiently disposed to comply with your kind invitation to visit old Milestown once more; but alas! my travelling days are rapidly drawing to a close. I hope to have strength enough to visit a son who is residing in Georgia, after which I shall be prepared, I trust, for my journey home to that better world where, washed from imperfection, we shall dwell with the pure and perfect at God's right hand. * * *

The journey to his son's home was not accomplished. He was again stricken with paralysis before it could be undertaken.

In September he had sufficiently recovered to permit his grandson, Jolın Haskell, to leave his side for his first visit to the North. We find an almost daily correspondence between his grandfather and himself. Shcrt letters in which the old Patriarch 
pours out to his young relative, the wealth of his tender love-addressing him no longer as a grand6on, but as " my dear son." Among John Haskell's papers, we find preserved the parting prayer offered by his grandfather on that occasion.

To J. B. Haskell :

Sept. 16th, '71.

Few sons are privileged to receive almost every day a letter from a father: you must take it as an evidence of my deep affection for you.

I am glad that you are well and happy. Let me advise you, if you wish to keep in the good graces of the home-folk, old and young. to keep them well posted with regard to all that interests you.

Give my kindest remembrance to every member of the Audubon family. The names of Audubon and Bachman are closely connected in science-the two men worked together pleasantly and harmoniously.

My health continues feeble, but I am thankful to our kind Father in heaven who has preserved my life for so many years.

I look to the atoning blood of my Saviour for the pardon of my sins and the salvation of my soul: and, if we can believe that God will save our souls, surely we can trust in His mercy for all the rest.

Your studies I have deeply at heart. Your tastes lie in a literary direction and you are well calculated for your chosen profession-Theology. Look up to your God and be fervent in prayer. Let nothing divert you from your high aims. Let your Heavenly Father ever be your director and guide. You see how anxious I am about you, my son. My fervent prayers and my best and last counsel is yours. You have heard of your uncle Wilson's recent 
trial-all his possessions destroyed by fire. I am glad that his losses occurred before my death, that I might do the little in my power to assist him, It comforts me to feel assured that we often learn more from adversity than from prosperity.

Your affectionate grandfather, J. B.

To A. R. Rude, D. D. : (Professor of Theology.)

"I have for some time thought of writing to you with regard to John Haske!l, his studies and pursuits. I indulge the hope that if his life is spared, he will give his energy and talents to the Church, and, at present, I see no obstacle to prevent the same: I desire to place him under your care as his teacher, adviser and friend. I do not know how long a wise Providence may permit him the privilege of studying under you, but I do know that you will endeavor to impart to him your best instruction and advice, and I feel confident, that his course will be such as will render him a credit to you and an ornament to the Church of his forefathers. He is the subject of daily thought, conversation and prayer I rejoice in the hope that when I am no longer on earth, I shall have left a grandson in the ministry.

With best wishes, my dear friend, for your prosperity, usefulness and happiness.

I remain, faithfully your friend, J. B.

\section{John Haskell to his Grandfather:}

\section{Audubon Park, Sept. 1st, '71.}

"I fear, my dear grandfather, that I havé not sent you as many letter's as I should, but I think often of you-indeed seldom have you long out of my mind. I have given the news and my impres: sions of many things in other letters, all of which were to be read to you. I am enjoying myself just 
as much as you could desire, and it would please you to look in upon me and see me well and happy. I have seen many interesting relics of Audubon, the Naturalist, and many happy traces of you. I have. met people who knew you, and if I had a little time to spare, should search out your relatives. I have seen much of men and things since I left you, and shall take away with me many pleasant impressions. The Audubons have treated me in the kindest man-, ner possible, and even strangers have shown me, unexpected hospitality.

While I am enjoying myself I am not unmindful of higher things.

This is only a little note written while I am waiting to go by train to the city-a Mr. W. has been my guide to the famous "Gold-room" with its Bulls and Bears, also to the Equitable Insurance Building. and to the Elevated Railroad, where we looked down upon the moving mass below us. **. I shall have much to tell you when we meet. In haste. Your loving grandson, J. B. H.

To his Grandson.

Charleston, Sept. 1871.

My dear Son-It is a great pleasure for me to write to you; lately I have had an impression that your letters, like angels' visits, are not frequent, but when they do come, though they do contain a little. nonsense, they are most acceptable. Rest a little now and recreate, and you will be the better able to carry on your studies.

Let us hear constantly fiom you, I want to know what impression new scenes make upon your mind; but above all, I crave to know from you that your heart is fixed, and that you will allow nothing. to divert you from the high aim you have proposed. 
to yourself, viz, the study of the ministry. Your chosen profession involves a nobler estate than any earthly field. When I am no longer here, remember, John, I confidently expect that you will tread in my footsteps; you possess more than a moderate share of talent and many advantages. Improve them all. 'To God I commit you; without His aid and blessing you can do nothing, with it you may accomplish almost any thing; prepare yourself not only to become a good preacher, but also a faithful pastor. Let us remain solid Lutherans, as firm as old Martin himself-we must be instructed by tho exarnple of our forefathers. Lean upon the arm of God; be faithful to duty, and He will bless and guide you. Your affectionate grandfather, J. B.

\section{JoHn Haskell, in reply.}

Columbia, Sept. 18th, 1871.

My dear Grandfather-I send you, as usual, a daily line. I shall soon turn my face homewards. I have much to tell you of deep interest-God has been good to me in every way. I have received your precious letters and dearly appreciate them. * *

My heart is full of gratitude for the opportunity and privilege to study for the Ministry. He gives me all that I ask for, and when He denies, I trust that I shall realize that it is because, with so many blessings, it is but just that I should have my share of trials.

I am gaining much by being with Dr. Rude. Whenever I go to his room, he gives me some work to do, and I am glad to help him. I expect to spend a great deal of time in his study. He has presented me with a most valuable book "The Conservative Reformation." by Krauth, which he says, will be a text-book for Lutheran Theology-I in- 
tend to make good use of it. He has lent me Max Muller's. "Chips from a German Workshop," which I am reading with deep interest.

It gives me joy to hear that your health is improving. I think of you a great deal, and have imagined or dreamed, more than once, that I heard you calling me in the night.

I have written at Dr. R.'s request, two or three articles for The Lutheran Visitor, and have copied out some old addresses, \&c., which, when you read, you will recognize. Dr. $R$. has encouraged me greatly; he salys that I am a good writer and a sprightly one; that I am to lay in knowledge and I shall do well. I do not take this as praise, but simply a truth that God has given me some gifts that I may use in His service-if one talent, then I must work liard to make it tell; if more, I must work very hard, for more will be required of me. Aunt Julia B. tells me that I have what she calls the Bachman characteristic of (knowingly) not troubling myself for the future-but trusting; if it be so, I am thankful and glory in the inheritance. Give me your blessing, iny grandfather, that it may act on me and re-act on yourself. God is taking good care of us all.

With much love to you, to the one who reads this to you-and to all.

I am ever, your loving grandson, Joun.

To Johy S. Fake, Esq., President of National Exchange Bank, of Lansington, N. Y.:

Mr. Fake's sister had married Dr. Bachman's brother, Henry.

Charleston, Sept. Sth, 1871.

My Dear Sir: I am under the impression that you and I are alrnost the only survivors of a large congregation and of many tried friendships. 
We once walked together, worshiped together; and prayed together; now many hundreds of miles separate us from each other. It is but naturel that: we should like to hear from each other in this world, and I shall be very happy if you would devote an hour or two to writing to me.

All the members of my old congregation at Schagticoke, I presume, have been removed to their rest. and reward.

A good God has long spared my life; I am: paralyzed, but suffer no pain. I am nearly eightytwo years of age, and am preparing for that last change that must come to all-with regard to my: prospects for eternity, my assured hope is in the atoning sacrifice of my Saviour.

Since I last wrote you, few changes have taken place in my family. I have one son in Columbia, practicing law, another a farmer and nurseryman in Georgia. I have around me two married and one single daughter ministering to my comfort. I have; seventeen grandchildren, and two great-grandchildren living.

One grandson is about to study for the ministryhe is a great source of comfort and pleasure to me. * $\quad * \quad * * \quad * \quad * \quad * \quad * \quad *$ : May God bless you, r repare you for your duties and trials on earth, and the rewards of the just be: yond the grave. I hope to meet you in that bright and happy world above.

Truly and ever, your friend, J. B.

To Rev. T. W. Dosir, of Virginia, who had been elected assistant Pastor of St. John's, Charleston :

Charleston, Nov. 15th, 1871.

My dear Friend and Brother: Your rery welcome letter of acceptance of the call extended to you. 
by my vestry and congregation, has drawn you very near my heart.

$\mathrm{W}$ e are to be connected by intimate ties-you are to be to me more than a brother-to engage in labors that once were mine. I pledge myself to do the little in my power to render your labors pleasant and satisfactory. As good Lutherans, our sole aim shall be to advance the best interests of the cause which we both love; and when our work on earth is ended, may we be fitted to enter into that rest prepared for the people of God.

I shall anxiously await your arrival, and, if my life is spared, welcome you and your dear family with an open heart.

Truly and devotedly your friend, J. B.

To the SAME:

Charleston, Dec. 20th, 1871.

In acknowledging the receipt of your kind letter of November 28th, in which you appoint the 10th of January as the time of your arrival among us, I cannot but express to you the pleasure it gives me to know that you will so soon be in our midst.

My mind has been greatly relieved by your acceptance of the call from our Church. I feel that I can place full confidence in you. I hope and believe that your coming to us will be productive of much good to the Church.

I have but a single request to make, which, I trust, you will not think unreasonable. My desire is that you, with every member of your family, may consider yourselves pledged to dine with me on the first day of your arrival, or as soon after as may be convenient and agreeable to you, so that you may dine at my house before you accept an invitation from any one else in Charleston. Come to us, we 
will welcome you with our whole hearts. With kind wishes for yourself and family,

Your friend and aged brother in Christ, J. B.

The illness and death of Dr. Dosh's youngest child detained him in Winchester. On the Sth of February he reached Charleston; the day after his arrival the wish of the old Pastor of St. John's was gratified-the families dined together in his home. Experienced in the school of suffering, he had ready words of Christian sympathy for the bereaved family. The close relation established between the two pastors from the beginning, remained uninterrupted to the end.

During the following months we find the record of many visits paid by Dr. Bachman. He would stop at the door of his parishioners; in a few minutes the grandmother and mother, with the baby, would come out to welcome him. Sometimes his companion would resign her seat to an invalid to whom he desired to give the fresh air. Month after month peacefully glided away. He had entered his eightythird year. The absent members of his family, on his birthday, sent him letters of congratulation, and in the home, friends united with the family in celebrating the day appropriately.

Alluding to this time, the Spring of 1872, John Haskell wrote: "Among the very last acts of my grandfather's life, was taking part in the Ladies Society of St. John's. Riding in his carriage to tho place of meeting, and being borne into the room, here he sat joyous among his heart's children. Ha 
opened the meeting with his short, but fervent prayer. The little children gathered around him to kiss the aged cheek and nestle near the cherished form."

On the 12th of June, a blow came to the heart of John Bachman, from which he never rallied-the death, after twenty-four hour's' illness, of his son-inlaw, Mr. William E. Haskell, who, like a devoted son, had watched over his declining years. He did not murmur, but his mind seemed utterly overwhelmed by the mysterious Providence that had left the aged man, who earnestly longed to depart, and had removed the younger-the active worker, upon whom so many depended.

John Haskell rose from a bed of sickness, and, with the strength of unselfish love, endeavored to fill up the gap. With a tenderness akin to angel ministry, he sought, and not in vain, to soothe and support the aged sufferer, who looked up to and leaned upon him-for "the almond tree" was beginning "to flourish and desire to fail." The notes of the singing bird no longer attracted his attention-all was a blank now-save the voice of a friend, and the name of Jesus.

Another birthday (4th February), and again another, was quietly celebrated in his home, and the love-offerings called forth grateful smiles. His decline was so gradual that his family were scarcely conscious of it, until the twelfth of February, 1874. 


\section{CHAPTER XXVIII.}

\section{The Close of Life.}

FROM JOIN HASKELL'S DIARY-FROM DR. WIGITMAN-DR. A. R. RUDE-J. F. FICKEN, ESQ.-MEMORIAL SERVICES-LINES BY PROF. W. J. RIVERS-BACHMAN ENDOWMËNT FUND-MURAL TABLET IN ST. JOHN'S CHURCII.

\section{$F^{\text {ROM John Haskell's Journal: }}$}

Thursday, February 12th, 1874 . I. went to my grandfather's chamber at 8 A. M. He was seated in his large arm-chair, where, at his request, he had been placed at $4 \mathrm{~A}$. M. I spoke to him but he did not answer. We saw that he had been stricken anew with paralysis.

Friday and Saturday. He remains in a complete lethargy.

Sunday 15th. This morning grandfather revived; his physicians pronounce that though the attack is over, he has not the strength to rally from it.

Miss Maria H., (the late Mrs. R. G. Chisolm) was with us, she sang " Gently, Lord, O gently lead us," and we joined in-as the singers sang hymn after hy'mn, he would say, "sing, yes, sing." It was a solemn and touching scene, and we were all moved to tears. I asked "Shall I read the Psalms?" He answertd "Yes!" I read the XCIst-" He that dwelleth in the secret place of the Most High, shall abide under the shadow of the Almighty;" and the last chapters from 
Revelations. While Aunt C. read hymns to him he repeated, in faltering accents, the familiar stanzas.

Monday. There is little change.

Tiesday. He is lying calm and peaceful, listening to passages from the Scriptures and hymns.

Wednesday. He is peacefully sleeping away his life into the arms of the Eternal.

Thursday. At one o'clock this morning, grandfather's brow and cheeks were cold, we thought him nearing his departure, but while we gazed he opened his eyes and put his hand to his head. I asked, "Do you know me?" He answered clearly "Yes"-and my heart poured itself out in thanksgiving to God for His tender mercy in comforting me. He looked inquiringly at Mr. F. who said, "it is John Ficken. We cannot forget to come to see our dear old pastor." Mr. Henry Steinmeyer spoke to him, he moved his lips, but we could not catch what he said.

Frum A. R. Rude, D. D.

Columbia, Feb. 19th, 1874.

Let the pilgrim go home to rest-to joy-to Him, who will crown his good and faithful servant. How providential was my last visit to Charleston (to administer the Holy Sacrament). His farewell kiss lingers on my lips and sanctifies them.

I shall come when you summon me.

From John Haskell's Journal:

Friday 20th. Grandfather has taken a little nour ishment. During the day. I read to him the 259th 
hymn (Book of Worship). After reading the line "Trust in the mercy of thy God," I asked, "Do you trust only in the Lord Jesus?" The answer came - "Yes"-clear and loud, all in the room heard it. Thanks be to God for all the abundant testimony to His glorious Gospel!

Revds. Honour and Bowman came in. Mr. Honour asked "Shall I read to you?" he answered in the affirmative, and his favorite hymns were selected. Then we sang-the whole family were in the room. It was a blessed scene and I pray God that it may be sanctified to us all.

\section{From Rev. Dr. Wightman.}

"I knew Dr. Bachman long, loved him well, and was honored with a place at his bedside. He called no man "father ;" but as an independent Christian philosopher, he brought into harmony the moral and material universe, and then fearlessly, in the very face of so-called science, pronounced his decisions in favor of the truth as it is in Christ. How ought such a man to die? There he lay on his couch serene and beautiful, with his white locks falling over his temples, and with a loving family caressingly gathered around his pillow. Though the great intellect had already set, yet the twilight before the approaching night, was so calm and sweet and radiant with the lingering light of a life spent for Christ, that the scene of that death-bed appeared to be just under the shadow of heaven."

The flowers he loved best were placed near him; his chamber was not darkened-only the glare of light shut out. As he lay there "under the shadow 
of heaven," his own description of the closing hours of a just man's life, written thirty-six years before, was singularly applicable.

1833. The Lake of Constance. The sun is just setting, and the very heavens seem to be in unison with the scene. The clouds, on a blue ground, have a rich and ruddy hue, and the outer edges arè wreatherl with silver. The Lake is an almost un* broken mirror. Behind me how different the scene - dark and murky clouds are hanging over the snow-clad Alps.

Now we are entering the little harbor of Con: stance-the boat is moving slowly; the sun seems to be setting almost behind the waters, rising and sinking at the moment of his departure, leaving a golden stream on the edges of the neighboring clouds, reminding me of the last hours of a just man's life-calmly, as the setting sun, his day closes, and the bright light of his example is left to edify and gladden the world.

\section{John Haskell's Journal.}

Friday evening. Dr. Rude has arrived. Aunt Julia B. crossed the room just now. Grandfather. asked, "Who is it?" On being told, he said, "I love her-I love you all." (Those were his last words.)

Monday evening. He has slept through to-day; scarcely breathing.

Tuesday. In the early morning, Aunts Jane and C. sent me to get a little rest. During the night, grandfather would, apparently, cease to breathethese cessations lasted for about thirty seconds. At 9.20 A. M., Aunt C. awoke me, saying that one of the 
cessations of breathing was longer than usual. I went down and watcher for a minute. The grand spirit had departed-asleep to the troubles of earth, awake to the bliss of eternity!

Rev. Mr. Dosh, Mr. Henry Steinmeyer, and myself robed him in the silk gown that the ladies of his congregation had made him, and we bore him in our arms to the drawing-room. He looks so placid, calm, peaceful, beautiful, like a saint-and he was a saint!

All day long the people are coming-how they love him! Old and young, rich and poor, refined and rough-all weep over him-they kiss him and call him father and friend. The love that this pure spirit won from all who came in contact with him: is wonderful.

Wednesday. Crowds have been here to-day. Little children asked to be lifted in our arms to kiss him: A strong, rough mechanic, with tears in his eyes, kissed his brow and eyes. Clergymen of every denomination have called.

Rev. Dr. Girardeau came, and said: "Your grandfather introduced me to the hospitals; he took me into the wards, while he talked with ill and dying men in their own tongues-German, Dutch, etc. I wondered how he could get through his pastoral duties, and yet find time to do so much in the hospitals. I never saw a man as active as he in every time of public calamity."

Until late at night they came-whites and colored-every station was represented. Hundreds caid, "He baptized me." 
St. Michael's Church (Episcopal) called a meeting to-day to give expression to their respect and admi. ration for him-they request permission to toll their: bell-old St. Michael's peal-for him. This is a touching and beautiful tribute-a Christian synpathy that rises ligh above all non-essential differences.

Thursday, 26th. At ten o'clock the obsequies took place. His remains, in a metallic casket, were borne to St. John's Church. The pall-bearers were all selected from the congregation. The faculty of "The Charleston College suspended the exercises of the College. 'The funeral cortége from the home. was very large, and the Church densely crowded." - St. John's had not been draped in mourning by stranger hands-her sons and daughters performed this "labor of love." Everywhere white was interwoven with the black-mourning below-joy above.

The services were conducted by Revs. T. W. Dosh, J. H. Honour, L. Müller: W. S. Bowman, and A. R. Rude, D. D.

The body was interred in a vault beneath the altar, above which rested a sable bier, concealed by a wealth of floral offerings.

The next Sunday, March 1st, a smitten flock gathered sadly in St. John's. The co-pastor, Rev. T. W. Dosh, preached from the text: Psalms xxxix : "Lord, make me to know mine cnd." He touchingly dwelt upon the long and faithful labors of their aged, departed Pastor.

Tributes were offered by most of the pulpits in Charleston. 
Love, fruitful in devices, kept the bier within the altar covered for six months, with fragrant flowersthe emblems of the resurrection.

[From Lutheran Visitor, os the Editor, A. R. Rude, D. D.] Died, in Charleston. S. C., T'uesday, February 24th, at 9.20, 'A. M., Kev. John Bachman, D. D., LL. D., D. Ph., Aged 84 Years and 20 Days,

Fully prepared long ago, watching, waiting; for, as he often had declared, his work was done; calmly, peacefully, withont a sigh, he slept, the spirit went to Jesus, and those who stood around the bed could not tell whether it was life or death.

Honored by all who knew him, loved by all whom he ministered to in holy things. a wise counsellor, a devoted friend, a learned inan, a fervent patriot, but, best of all, a devoted Christian, a faithful minister of the Gospel, an example to all; in him his family, society, and the Church have lost one whose like we know not where to seek, whose place we know not who can fill. Even for the last two years, when unable to appear in public, unable to serve at the altar and in the pulpit, and confined to the house and the sick-room, he yet was a tower of strength, a shining and burning light, and a living witness of the blessed truth, that "now abideth Faith, Hope and Charity, these three, but tho greatest of these is Charity."

Though a learned man, though he had known every plant "From the liyssop on the wall, to the cedar on Lebanon," every beast, crecping thing and bird of many lands, he, during the closing years, forgot all. The works he lost sight of, the Workman, the Creator. he remembered; the sciences were to him things of the dear past; the Bible was to the last his precious all. The Psalms, the words 
of Jesus, were as manna to his soul; on these he fed, by these his soul's life was sustained, and his spirit strengthened for its upward flight.

It was not our privilege to know him many years, but we do rejoice and feel that it was good for us to know him well during the beautiful and holy sunset of his long, eventful and noble Christian life. For years before we met him, we had heard much of him. His praise was in all the Churches. We were proud of him, we felt stronger because he was one of us and with us, and we loved him, because all bore witness to his love for Christ, the Church and the brethren.

At last we met. Our first meeting was in Virginia, during the war. He had come from his far-off lome in "the City by the Sea," to minister to the physical and spiritual wants of the soldiers from his adopted State. The next time we met was at Concord, N. C.., where he, by his wise counsel and gentle firmriess, contributed largely to the formation of our General Synod, of which he was the first President. After that we enjoyed the genial hospitalities of his pleasant home, and then we met again and again in Columbia, Charleston, at the meetings of the General Synod and the Synod of South Carolina. In sorrow and in joy, at the cradle and the grave our intercourse was always pleasant, our cominunion always blessed; we feel that we owe him much, that his counsels, his prayers, his example, his suffering, his faith, hope and love so transcendantly displayed in the most trying circumstances, have made us better, and brought us nearer the heavenly gates. $\mathrm{He}$ entered in before us; a host of washed and bloodbought souls, whose spiritual father in the Lord he was, have welcomed him; and here below, still waiting and serving. is a large multitude whom he taught to love the name of Jesus. 
One thing we must not pass over, and that is his clear comprehension and his unconditional reception of, his fervent attachment for, and his adherence to, the Confession of the Evangelical Lutheran Church. The Lord himself was his teacher. And to us and to many others it was a constant cause for gratitude and rejoicing that the grayhaired soldier of the Cross during the last years of his life bore such unequivocal, constant and firm testimony to the articles of our faith, as set forth in the Augustana. Verily he was a true and faithful witness; he did a great and good work; many shall rise up and call him blessed; and though dead, he yet speaketh, yes, and speak he will, to the close of time and throughout eternity.

And he is dead! For years we had expected it. We watched at his bedside, but did not see him die, for he died so gently, so sweetly, nay, he rather went to sleep, and he now sleeps in Jesus, in whom he believed, and whom he loved; and served as a preacher of His great salvation for more than fourscore years, and who was his refuge and is his rest.

- On Sunday, March 8th, amid the emblems of mourning, and in sight of the flower-crowned bier, St. John's put on record her tribute of affection and esteem for John Bachman, the servant of God, who "from early manhood until the close of a long life, went in and out before his people, as a priest in the temple of Jehovah."

The Preamble and Resolutions were offered by one of the Vestry, John F. Ficken, Esq.

Sunday, April 26th. Memorial services were held in St. John's Church, conducted by the Pastor, Rev. T. W. Dosh, assisted by Revds. J. H. Honour, L. 
Müller, IV. S. Bowman, and J. Fry, D. D., of Reading, Pa.

The Pastor's text was from Proverbs x. 7, "The memory of the just is blessed."

He closed his chaste eulogy on the departed, with the following beautiful tribute from Professor W. J. Rivers, of Baltimore, Md., formerly of Charleston, S. C. Professor Rivers had sat under the teaching of Dr. Bachman, from childhood to manhood.

\section{REV. JOHN BACHMAN, D. D.}

In life or death no evil cán befall

$\therefore \quad$ The pure in heart: Their pains and griefs but servo.

As trials here, while at the gate of death

God's angels stand and watch their coming steps

To lead them on to endless peace in Heaven.

By faith uplifted, they disdain as dross

This world's false glory and its fleeting wealth,

And count not aught their own save that which is

Forever theirs: Their peace, their love to man,

Their holiness engendered in the soul,

Which thereby to the likeness of its God

Redeemed, is with angelic glory erowned.

This is thy wreath, the fruitage of a life of prayer and pious deeds-thy peace, thy crown. 'Thy home in Heaven, bless'd minister of Christ!

Though with her treasures Science wooed thy mind, And Nature brought, as to her votary, flowers And fruits, and from each distant region, bird And beast, as erst in Eden, to be namedStill ever to the Father's will-revealed, Pure fountain of His truth, thy thought was turned; And ever, with unquestioning trust, was heard His mandate to go forth and preach $\mathrm{His}$ Word, : That haply it might kindle in our souls The faith and love and hope that quickened thine.

Guide to the wanderer, helper of the wronged, The orphan's guardian and the widow's friend, Sweet counsellor to all. $O$ ! if from Heaven All else of sinful earth should be debarred 
Save guileless love, and such a love as ours An entrance hath-comes there not now to greet Thy happy soul the whispered words we breathe From mournful hearts, as bending o'er thy grave These wreaths we strow and fondly bless thy name?

The Synod of South Carolina, on its 50th Jubilea determined to raise a fund to be called:

"The Bachman Endowment Fund of Newberry College."

"A grateful tribute to the memory of John Bachman, through whom pre-eminently the Synod and College had their origin."

A. mural tablet in the Church of St. John's, Charleston, bears the following inscription :

\section{SACRED}

To the Memory of

REv. JOHN BACHMAN, D. D., IL. D.

Born in Rhinebeck,

Dutchess County, State of New York,

4th Feb., A. D. 1790,

Died in this City

24th Feb., A. D. 1874.

Distinguished in Science,

Eminent for Piety, Brave and Faithful in devotion to God and his Church.

For sixty years he was the beloved and revered Pastor of this Congregation, commanding the unbounded esteem of a whole community.

His Remains Repose under the Altar of this Church. 


\section{APPENDIX.}

\section{LisT OF DR. BAChMAN'S PUBLISHEd WORKS.}

Address delivered before the Horticultural Society of Charleston, S. C. July, 1833.

On the Migration of the Birds of North America. Published in 1833.

Catalogue of Phænogamous Plants and Ferns, native and naturalized, growing in the vicinity of Charleston, S. C. Published in 1834 .

Experiments made on the Habits of Vultures inhabiting Carolina-Turkey Buzzard and Carrion Crow. Published in 1834.

Contributions in the Southern Agricultural Journal, published as editorials, from 1835 to 1840 .

Monograph of the Hares of America, including several undescribed species. Published in 1837.

Monograph of the Genus Sciurus, including several new species. Published in Transactions of the Zoölogical Society, London, 1838.

The Changes in the colors of Feathers in Birds, and of Hair in Animals. Published in Philoscphical Transactions, Philadelphia, 1839.

Address before the Washington Total Abstinence Society. July, 184?.

Sermon against Duelling, about 1842.

The Quadrupeds of North America. (3 Volumes.) Published jointly with Audubon. Figures by Audubon, text by Bachman. (The first volume appeared in 1845, the last in 1849). 
On the Introduction and Propagation of Fresh-water Fish. Published about 1848.

The Doctrine of the Unity of the Human Race, examined on the Principles of Science. Published in 1850.

Defence of Luther and the Reformation. Published in 1853. Notice of the Types of Mankind (by Nott \& Glidrlon), with an examination of the Charges contained in the Life of Dr. Morton. Published in 1854, in "The Charleston $\therefore$ Merlical Journal."

An Examination of the Characteristics of Genera and Species, as applicable to the Doctrine of the Unity of the Human Race. Published in 1855.

An Examination of Prof. Agassiz's Sketch of the Natural Provinees of the Animal World, and their relation to - the different types of men. Published in 1855.

Address delivered at the Laying of the Corner-stone of 1. Newberry College, $18 \bar{\top} \bar{\tau}$.

Report on Asiatic Goats. Published by order of "Tho Southern ('entral Association of Georgia," in 1857.

Sernion on the Forty-Third Anniversary of his Ministry $\because \quad$ in Charleston. 
RETURN TO the circulation desk of any University of California Library or to the

NORTHERN REGIONAL LIBRARY FACILITY Bldg. 400, Richmond Field Station University of California Richmond, CA 94804-4698

ALL BOOKS MAY BE RECALLED AFTER 7 DAYS

- 2-month loans may be renewed by calling (510) 642-6753

- 1-year loans may be recharged by bringing books to NRLF

- Renewals and recharges may be made 4 days prior to due date.

\section{DUE AS STAMPED BELOW}

Stch 18 - 1 mum

\section{BEC 181998}




\section{№ 480829}

\section{Bachman, C.L.} John Bachman.
QL31

B2

B2 
$6 \frac{3}{4}$

side

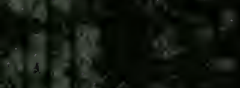

$4 y^{3} y^{2}=$

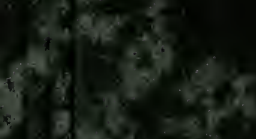

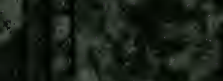

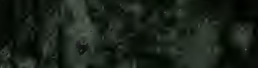

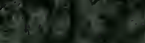

ad

a. 1 y $=24$

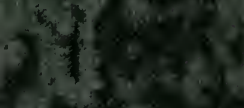

ent $=2 x$

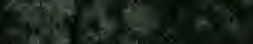

21.

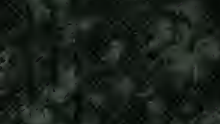

$x^{x}+x^{2} x^{2} x^{2}$

5. $50-3+2$

$24+x^{2}-2 x=2$

$(x, y) \times 3=$

6

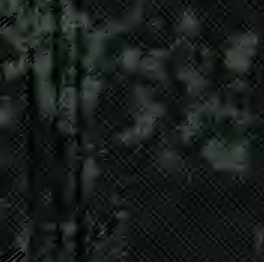

$\frac{25}{2}$

(x)

i.

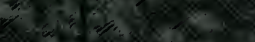

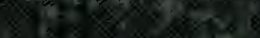
1.

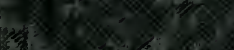

$2 x$

(4)

i. $131 \frac{5}{2}$ \&

$x+1 \% 2 \pi+3$

2.t.

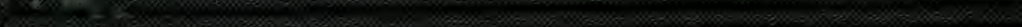

$-3005$ 